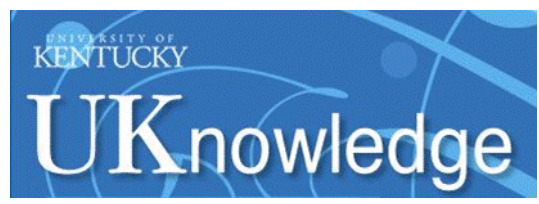

University of Kentucky

UKnowledge

\title{
Mass Flux of Agricultural Nonpoint-Source Pollutants in a Conduit-Flow-Dominated Karst Aquifer, Logan County, Kentucky
}

James C. Currens

University of Kentucky, currens@uky.edu

Follow this and additional works at: https://uknowledge.uky.edu/kgs_ri

Part of the Environmental Monitoring Commons, Geology Commons, and the Natural Resources

Management and Policy Commons

Right click to open a feedback form in a new tab to let us know how this document benefits you.

\section{Repository Citation}

Currens, James C., "Mass Flux of Agricultural Nonpoint-Source Pollutants in a Conduit-Flow-Dominated Karst Aquifer, Logan County, Kentucky" (1999). Kentucky Geological Survey Report of Investigations. 3. https://uknowledge.uky.edu/kgs_ri/3

This Report is brought to you for free and open access by the Kentucky Geological Survey at UKnowledge. It has been accepted for inclusion in Kentucky Geological Survey Report of Investigations by an authorized administrator of UKnowledge. For more information, please contact UKnowledge@lsv.uky.edu. 


\title{
Mass Flux of Agricultural Nonpoint-Source Pollutants in a Conduit-Flow-Dominated Karst Aquifer, Logan County, Kentucky
}

\author{
James C. Currens
}

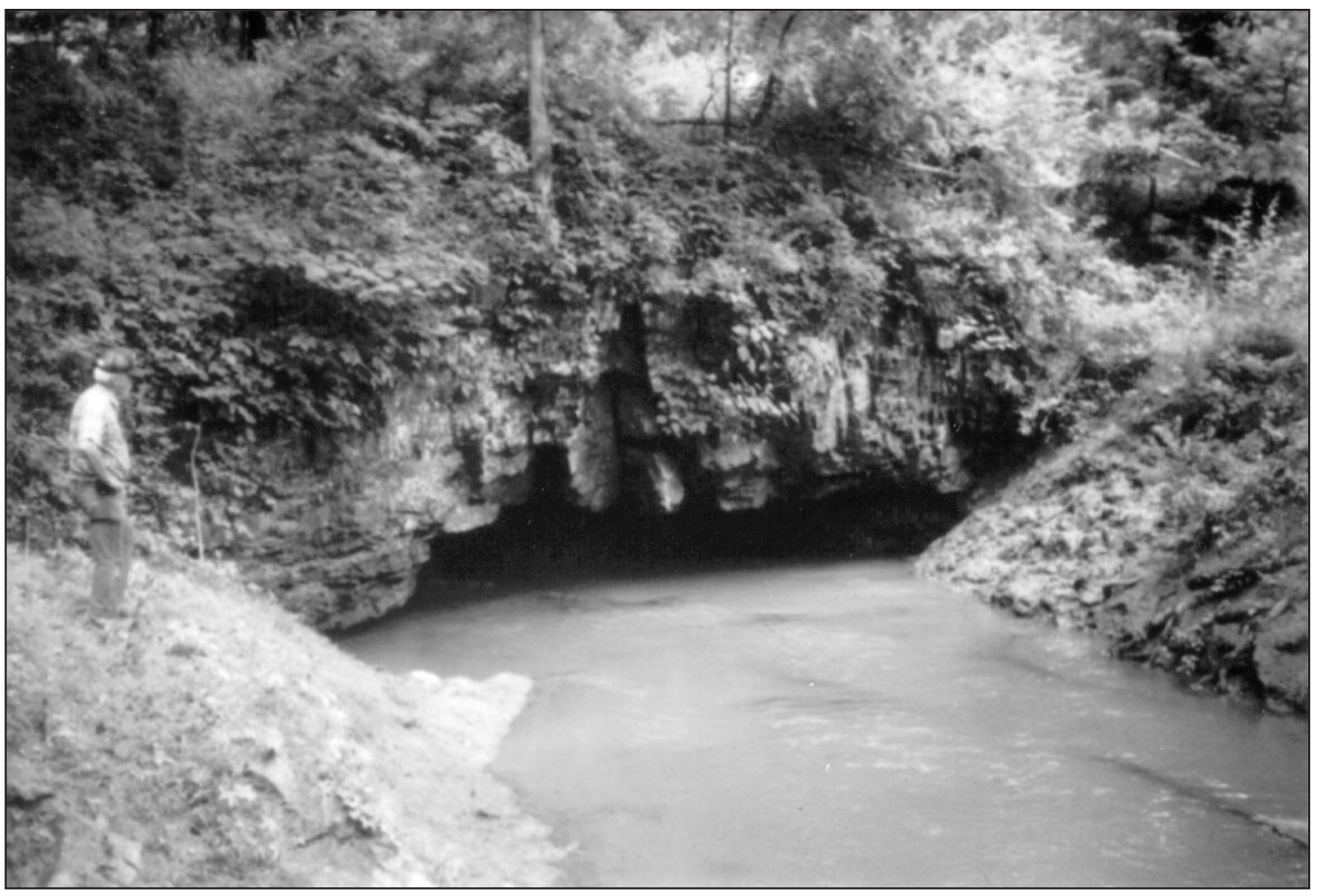


Kentucky Geological Survey

James C. Cobb, State Geologist and Director

University of Kentucky, Lexington

\title{
Mass Flux of Agricultural Nonpoint-Source Pollutants in a Conduit-Flow-Dominated Karst Aquifer, Logan County, Kentucky
}

\author{
James C. Currens
}




\section{UNIVERSITY OF KENTUCKY}

Charles T. Wethington Jr., President

Fitzgerald Bramwell, Vice President for Research and Graduate Studies

Jack Supplee, Director, Administrative Affairs, Research and Graduate Studies

\section{KENTUCKY GEOLOGICAL SURVEY ADVISORY BOARD}

Jacqueline Swigart, Chair, Louisville

Henry M. Morgan, Vice Chair, Utica

William W. Bowdy, Fort Thomas

Steve Cawood, Frankfort

Hugh B. Gabbard, Winchester

Kenneth Gibson, Madisonville

Ron D. Gilkerson, Lexington

Mark E. Gormley, Versailles

Rosanne Kruzich, Louisville

W.A. Mossbarger, Lexington

John F. Tate, Bonnyman

David A. Zegeer, Lexington

Ralph N. Thomas, Emeritus Member, Owensboro

George H. Warren Jr., Emeritus Member, Owensboro

\section{KENTUCKY GEOLOGICAL SURVEY}

James C. Cobb, State Geologist and Director

John D. Kiefer, Assistant State Geologist

Donald C. Haney, State Geologist Emeritus

\section{ADMINISTRATIVE DIVISION}

Personnel and Finance Section:

James L. Hamilton, Administrative Staff Officer II

Jackie Silvers, Administrative Staff Officer I

Clerical Section:

Juanita G. Smith, Office Assistant, Henderson office

Office of Communications and Technology Transfer:

Carol L. Ruthven, Manager

Margaret Luther Smath, Geologic Editor III

Douglas W. Reynolds Jr., Geologist II, Communications

Coordinator for the Kentucky Board of Registration for

Professional Geologists

Terry D. Hounshell, Chief Cartographic Illustrator

Michael L. Murphy, Graphic Design Technician

Collie Rulo, Graphic Design Technician

Shirley Davis Dawson, Staff Support Associate II

Well Sample and Core Library:

Patrick J. Gooding, Manager

Robert R. Daniel, Senior Laboratory Technician

Office of Geologic Information:

Bart Davidson, Manager

Richard A. Smath, Geologist II, Earth Science Information

Center Coordinator

Kevin J. Wente, Geologist I

William A. Briscoe III, Publication Sales Supervisor

Roger S. Banks, Account Clerk I

Luanne Davis, Staff Support Associate II

Theola L. Evans, Staff Support Associate I
Computer and Laboratory Services Section:

Steven Cordiviola, Head

Richard E. Sergeant, Geologist IV

Joseph B. Dixon, Information Technology Manager I

James M. McElhone, Information Systems Technical

Support Specialist IV

Henry E. Francis, Scientist II

Karen Cisler, Scientist I

Jason S. Backus, Research Analyst

C. Lee Helms, Research Analyst

Steven R. Mock, Research Analyst

Mark F. Thompson, Research Analyst

\section{GEOLOGICAL DIVISION}

Coal and Minerals Section:

Donald R. Chesnut Jr., Head

Garland R. Dever Jr., Geologist V

Cortland F. Eble, Geologist V

Gerald A. Weisenfluh, Geologist V

David A. Williams, Geologist V, Henderson office

Stephen F. Greb, Geologist IV

William M. Andrews Jr., Geologist II

Ernest E. Thacker, Geologist I

Geologic Mapping and Hydrocarbon Resources Section:

James A. Drahovzal, Head

Warren H. Anderson, Geologist IV

David C. Harris, Geologist IV

Brandon C. Nuttall, Geologist IV

Thomas N. Sparks, Geologist III

Douglas C. Curl, Geologist II

John B. Hickman, Geologist II

Steven L. Martin, Geologist II

Jason A. Patton, Geologist II

Anna E. Watson, Geologist I

Xin-Yue Yang, Post-Doctoral Scholar

R. Shawn Duncan, Geological Technician

Christopher P. Hettinger, Geological Technician

Michael P. Solis, Geological Technician

Water Resources Section:

James S. Dinger, Head

Daniel I. Carey, Hydrologist V

R. Stephen Fisher, Hydrogeologist V

David R. Wunsch, Hydrogeologist V

James C. Currens, Hydrogeologist IV

John F. Stickney, Hydrogeologist IV

Alex W. Fogle, Hydrologist III

Robert E. Andrews, Hydrogeologist II

E. Glynn Beck, Hydrogeologist II, Henderson office

Dennis H. Cumbie, Hydrogeologist II

Carlos M. Galcerán Jr., Hydrogeologist II

C. Douglas R. Graham, Hydrogeologist II

Philip K. Fields, Geological Technician, Henderson office

Gregory L. Secrist, Geological Technician

Steven E. Webb, Geological Technician

Geologic Hazards:

Edward W. Woolery, Geologist IV 


\section{Mission Statement}

The Kentucky Geological Survey at the University of Kentucky is a State-mandated organization whose mission is the collection, preservation, and dissemination of information about mineral and water resources and the geology of the Commonwealth. KGS has conducted research on the geology and mineral resources of Kentucky for more than 150 years, and has developed extensive public databases for oil and natural gas, coal, water, and industrial minerals that are used by thousands of citizens each year. The Survey's efforts have resulted in topographic and geologic map coverage for Kentucky that has not been matched by any other state in the Nation.

One of the major goals of the Kentucky Geological Survey is to make the results of basic and applied research easily accessible to the public. This is accomplished through the publication of both technical and nontechnical reports and maps, as well as providing information through open-file reports and public databases. 


\section{Acknowledgments}

Edited by-Margaret Luther Smath

Photography-James C. Currens

Cover design-Collie Rulo

Drafting-Terry D. Hounshell

Word Processing-Shirley D. Dawson

(C) 1999

University of Kentucky

For further information contact:

Manager, Office of Communications and Technology Transfer

Kentucky Geological Survey

228 Mining and Mineral Resources Building

University of Kentucky

Lexington, KY 40506-0107

ISSN 0075-5591 


\section{Contents}

Abstract 1

Introduction $\mathbf{1}$

Purpose 2

Acknowledgments 2

Study Area Description 2

General Setting 2

Geology and Hydrogeology 4

Soils 5

Previous Research 5

Methodology 6

General Strategy $\mathbf{6}$

Assumptions 6

Land-Use Mapping $\mathbf{6}$

Chemical Use 8

Ground-Water Dye Tracing 8

Optical Brightener Detection $\mathbf{8}$

Monitoring Equipment $\mathbf{8}$

Discharge Measurement 9

Sample-Collection Methods $\mathbf{1 0}$

Sampling Schedule $\mathbf{1 1}$

Analytical Methods and Quality Control 12

Quantification of ELISA 12

Mass-Flux Calculation 13

Results 13

Land-Use Mapping 13

Precipitation Analyses 13

Hydrogeology 14

Ground-Water Basin Boundary Mapping 14

Ground-Water Flow Regimes 15

Ground-Water Quality 16

Pesticides 18

Nutrients 19

Bacteria 20

Optical Brighteners (Domestic Sewage) 21

Volatile Organic Compounds (Petroleum) 22

Effect on Drinking-Water Supplies 22

Flow Regimes and Contaminants 23

Annual Mass Flux of Pesticides and Nitrate at Pleasant Grove Spring 23

Annual Flux at Upstream Sites $\mathbf{2 6}$

High-Flow Events at Pleasant Grove Spring $\mathbf{2 6}$

Conclusions 31

Summary 34

References Cited 36 


\section{Contents \\ (Continued)}

Appendix A 40

Appendix B 45

Appendix C $\mathbf{5 0}$

Appendix D $\mathbf{5 3}$

Appendix E 58

Appendix F 62

Appendix G 74

Appendix H $\mathbf{1 1 5}$

Appendix I $\mathbf{1 1 7}$

Appendix J 146

\section{Plates}

1. Map showing water-well locations and potentiometric surface with hypothesized flow routes In pocket

2. Map showing karst features and ground-water dye-trace vectors In pocket

\section{Figures}

1. Map showing location of the Pleasant Grove Spring drainage basin 3

2. Photograph of an example of a large crop field in the study area 4

3. South-north geologic cross section of the study area 4

4. Generalized map showing land use as of February $1992 \quad 7$

5. Photograph of instrumentation in the mouth of Pleasant Grove Spring 9

6. Photograph of discharge measurements being made at Pleasant Grove Spring during the May 1993 high-flow event $\mathbf{1 0}$

7. Graph showing stage versus discharge rating curve for Pleasant Grove Spring $\mathbf{1 0}$

8. Cross-plot of triazine determinations by ELISA versus atrazine determinations by GC 12

9. Cross-plot of metolachlor determinations by ELISA versus metolachlor determinations by GC 13

10. Discharge hydrograph and chemographs for Shackelford Spring compared with discharge hydrographs and chemographs for Pleasant Grove Spring $\mathbf{1 7}$

11. Piper diagram of major ionic constituents for Pleasant Grove and Shackelford Springs 18

12. Discharge hydrograph, and graphs showing temperature, conductivity, nitrate-nitrogen concentration, and combined concentrations of atrazine before April 1992 and triazines after April 199220

13. Line plot of phase I bacteria counts, temperature, conductivity, and discharge for Pleasant Grove Spring 21

14. Line plot of phase II bacteria counts, temperature, conductivity, and discharge for Pleasant Grove Spring 22

15. Plot of precipitation, discharge, nitrate-nitrogen concentration, nitrate-nitrogen flux, triazine concentration, and atrazine-equivalent triazine flux for Pleasant Grove Spring for the 1992-93 water year 23

16. Plot of precipitation, discharge, nitrate-nitrogen concentration, nitrate-nitrogen flux, triazine concentration, and atrazine-equivalent triazine flux for Pleasant Grove Spring for the 1993-94 water year 24

17. Plot of precipitation, discharge, nitrate-nitrogen concentration, nitrate-nitrogen flux, triazine concentration, and atrazine-equivalent triazine flux for Leslie Page karst window for the 1993-94 water year 27 


\section{FIGURES (CONTINUED)}

18. Discharge hydrograph and chemographs for the June 1992 high-flow event at Pleasant Grove Spring 28

19. Discharge hydrograph and chemographs for February 1993 high-flow events at Pleasant Grove Spring 29

20. Chemographs and discharge hydrograph for the May 1993 high-flow event at Pleasant Grove Spring 30

21. Discharge hydrograph and chemographs showing elevated atrazine-equivalent triazine flux during an early-winter high-flow event at Pleasant Grove Spring 31

22. Stage hydrograph for George Delaney swallow hole and discharge hydrograph and chemographs for Pleasant Grove Spring 32

23. Chemographs and discharge hydrograph for Pleasant Grove Spring 33

24. Discharge hydrograph and chemographs for the March 1994 high-flow event at Pleasant Grove Spring 34

25. Discharge hydrograph and chemographs for the April 29, 1994, high-flow event at Pleasant Grove Spring 35

\section{TABLES}

1. Purpose of and application rates for pesticides commonly used in Logan County $\mathbf{9}$

2. Maximum permissible contaminant levels for drinking water $\mathbf{1 6}$

3. Summary of annual precipitation, discharge, and agricultural chemical mass flux in the Pleasant Grove Spring Basin 24 


\title{
Mass Flux of Agricultural Nonpoint-Source Pollutants in a Conduit-Flow-Dominated Karst Aquifer, Logan County, Kentucky
}

\author{
James C. Currens
}

\begin{abstract}
Changes in water quality in a karst ground-water basin used intensively for agriculture are being measured before, during, and after the implementation of best management practices (BMP's) and other management practices, to determine the success of such programs in protecting ground water. The study was divided into three phases. The results of the first two phases are included in this report and cover research conducted between August 1990 and October 1994. During phase I of the study the overall ground-water quality of the basin and its hydrogeology were investigated. Phase II began monitoring the water quality at Pleasant Grove Spring before BMP implementation.

The Pleasant Grove Spring Basin in southern Logan County, Ky., was selected for study because it is largely free of nonagricultural pollution sources. About 70 percent of the watershed is in crop production and 22 percent is pasture. The area of the karst drainage basin is approximately 10,054 acres $(4,069$ hectares), as determined by ground-water dye tracing. Ground-water flow in the basin is divided into a diffuse (slow) flow regime and a conduit (fast) flow regime. The diffuse and conduit flow regimes have a major influence on the timing of contaminant peaks and valleys during storms.

Nitrate is the most widespread, persistent contaminant in the basin, but concentrations average $5.2 \mathrm{mg} / \mathrm{L}$ basinwide and generally do not exceed maximum contaminant levels (MCL's) set by the U.S. Environmental Protection Agency for drinking water. Atrazine has been consistently detected in low concentrations, and other pesticides occasionally are detected. Concentrations of triazines (including atrazine) and alachlor have exceeded drinking-water MCL's during spring flooding. Maximum concentrations of triazines, carbofuran, metolachlor, and alachlor in samples from Pleasant Grove Spring were 44.0, 7.4, 9.6, and $6.1 \mu \mathrm{g} / \mathrm{L}$, respectively. Flow-weighted average concentrations for 1992-93 were $4.91 \mathrm{\mu g} / \mathrm{L}$ for atrazine-equivalent triazines and $5.0 \mathrm{mg} / \mathrm{L}$ for nitrate-nitrogen. Averages for $1993-94$ were $0.97 \mu \mathrm{g} / \mathrm{L}$ and $5.7 \mathrm{mg} / \mathrm{L}$, respectively. The difference in atrazine-equivalent triazine concentration between the 2 years may be either the result of weather conditions or crop patterns.

Bacteria counts always exceed standards for drinking water and occasionally exceed standards for drinking-water supplies. Basinwide, samples averaged 465 fecal coliform colony-forming units per $100 \mathrm{ml}(\mathrm{col} / 100 \mathrm{ml})$ and 1,891 fecal streptococci col/100 ml; maximum counts were 14,000 and $24,000 \mathrm{col} / 100 \mathrm{ml}$, respectively. Bacteriological speciation failed to identify the source of high bacteria counts at Pleasant Grove Spring, but showed that the bacteria are not indigenous to the natural environment of the basin.

Suspended sediment discharging from Pleasant Grove Spring has had an adverse impact on aquatic biota downstream.

In the Pleasant Grove Spring Basin, ground water for human consumption is adversely affected by contamination from triazines and bacteria. Implemented BMP's should focus on reduction of runoff, disposal of animal waste, and efficient application of nutrients. A public education program on ground-water protection would also be beneficial.
\end{abstract}

\section{INTRODUCTION}

Karst aquifers are the water-bearing zones in terrains characterized by sinkholes, sinking streams, and caves. Ground water in karst aquifers occurs in partially to completely water-filled caverns, joints, and other fractures in the otherwise relatively impermeable limestone bedrock, and in soil mantling the solution-etched bedrock. Almost all ground water in karst basins eventually flows into caverns, from which it flows to discharge at a spring. Karst aquifers are notoriously sensitive to ground-water pollution because runoff from contaminant sources on the surface often enters the aquifer di- 
rectly through sinking streams and sinkholes, without filtration.

The most productive agricultural region in Kentucky follows the karst plain that extends in a belt from westcentral Kentucky, south to the Tennessee state line, then west across the southwestern quarter of Kentucky. Large farms produce corn, wheat, soybeans, tobacco, milo, rye, and barley from the thick and fertile soil overlying a gently rolling landscape. Logan County, the location of this study, produced more than $\$ 71$ million in crop and livestock receipts in 1992, making it the sixth-ranking county in the State (Kentucky Agricultural Statistics Service, 1993). Not coincidentally, some of the most serious ground-water contamination problems in the State occur in these same areas (Nitzkin and Henry, 1971; Kentucky Division of Water, 1988). Recently, water supply has become a significant limitation on economic development in Logan County (Joseph L. Taraba, University of Kentucky College of Agriculture, oral commun., 1996).

\section{Purpose}

Because agriculturally derived contaminants have been detected in municipal drinking-water supplies, as well as in domestic water wells, public concerns about the impact of agriculturally derived pollutants in general have been heightened. Pesticides are the primary safety concern, but fertilizers also play a role in the degradation of ground-water supplies. Furthermore, in karst areas, sediment eroded from fields and animal waste washed from pastures and feedlots also pollute ground water. Conduit springs supply most of the base flow to surface streams in karst regions, from which many municipal suppliers obtain their water source. Regulating farming practices, however, would lower productivity and increase the costs of food. The purpose of this research is to determine if programs and farming practices already in existence can be used to effectively protect ground water in karst aquifers from agriculturally derived contaminants, without resorting to regulation. If voluntary programs are effective, then both the public safety and the independence of farmers can be protected.

Protection techniques and farm management strategies to safeguard both surface- and ground-water quality and to minimize soil erosion have been developed and tested at plot, field, and farm scales. The Pleasant Grove Spring karst ground-water basin was chosen to test whether a program to install new or modified best management practices (BMP's) and an education program to enhance public attitudes about ground water will improve the quality of water in a karst ground-water basin at a large scale. This report summarizes the results of phase I (field reconnaissance and watershed mapping) and phase II (water-quality characterization and quantification before BMP implementation). Data in this report were collected between August 1990 and October 1994. Additional data are available through the hydrologic database at the Kentucky Geological Survey.

\section{ACKNOWLEDGMENTS}

The author wishes to thank the University of Kentucky College of Agriculture and the U.S. Environmental Protection Agency, who provided financial support for this research, via the Kentucky Division of Water, Nonpoint-Source Program. Bill Johnson, of the Logan County office of the Natural Resources Conservation Service, provided invaluable help in contacting farmers, acquiring crop and chemical-use data, and field support. Stan Asbridge, of the Consolidated Farm Services Agency, loaned annual aerial photographs of crops, and his staff provided training in their interpretation. Steve Crabtree, of the Boone County office of the Natural Resources and Conservation Service, digitized land-use maps and calculated crop areas. Mark Coyne, of the University of Kentucky College of Agriculture, conducted valuable bacterial speciation analyses. Joe Meiman, of Mammoth Cave National Park, conducted scanning fluorometer analyses. More than 40 area farmers graciously allowed access to their property and helped locate springs and other karst features. Without the farmers' interest and cooperation, this research would not have been possible, and their help is gratefully acknowledged.

Reconnaissance sampling and watershed mapping began in February 1991 when funding was received through the University of Kentucky College of Agriculture from Kentucky Senate Bill 271. Most equipment purchases and roughly half of the analytical costs through spring 1992 were paid for by SB-271 funds. Additional funding was received in April 1992 through the Kentucky Division of Water (Memorandum of Agreement 011399) from the U.S. Environmental Protection Agency's Nonpoint-Source Program (section 319 of the Clean Water Act). Phase II funding was received in September 1993, also through the 319 program (Memorandum of Agreement 012875).

\section{Study Area Description General Setting}

The study area is centered in south-central Logan County. Pleasant Grove Spring is about $9 \mathrm{mi}(14.5 \mathrm{~km})$ south of Russellville (Fig. 1). The study area includes parts of the Russellville, Dennis, Dot, and Adairville 7.5minute quadrangles. Pleasant Grove Creek flows south 


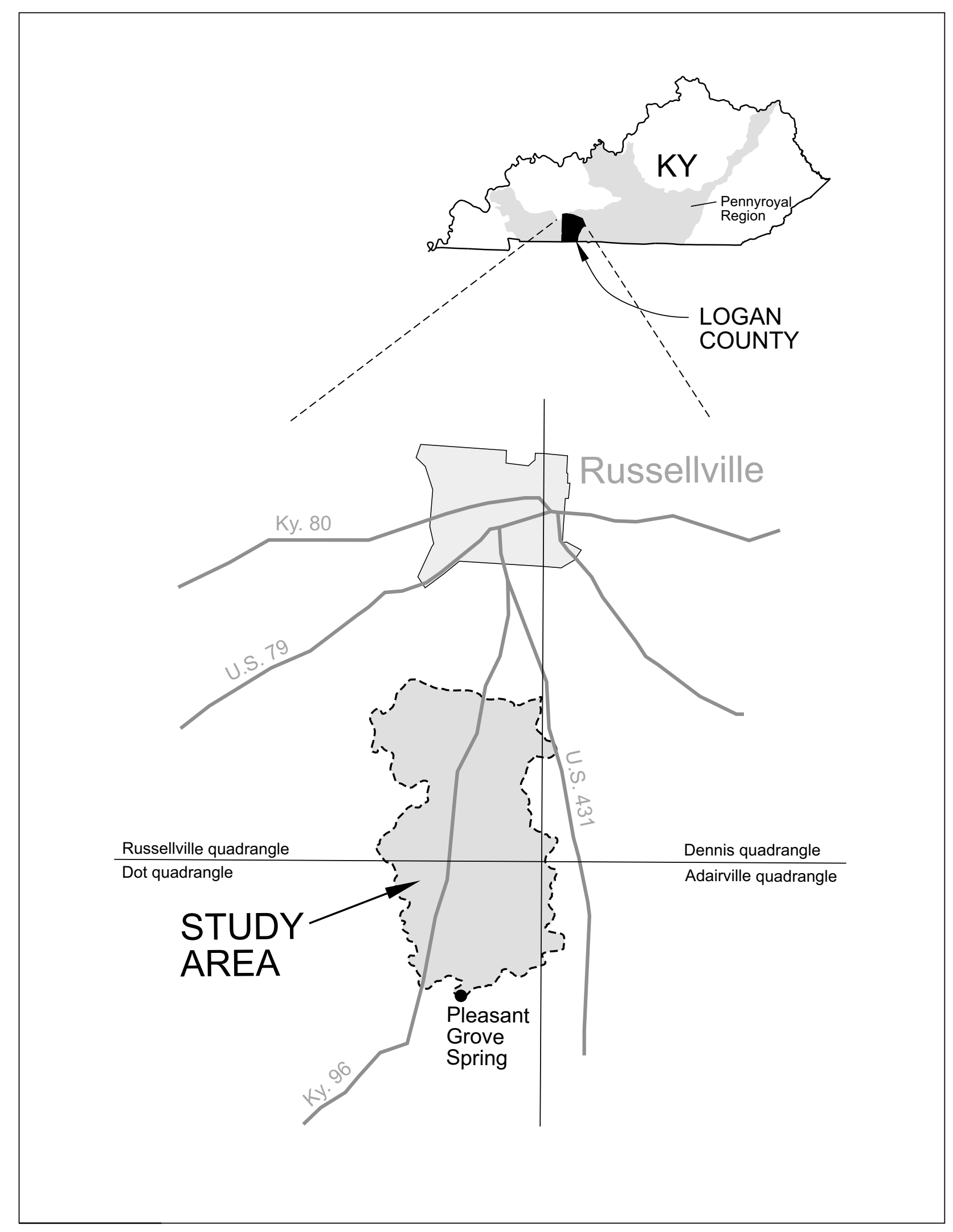

Figure 1. Location of the Pleasant Grove Spring drainage basin. 
$1.5 \mathrm{mi}(2.4 \mathrm{~km})$ to the Red River from its origin at Pleasant Grove Spring. For the purposes of this report, reaches of surface flow in the headwaters area of the basin, upstream of major swallow holes, are collectively called Upper Pleasant Grove Creek.

Pleasant Grove Spring Basin lies entirely within the Mississippian Plateaus physiographic region, which is developed on thick carbonates of Late Mississippian age. Topography in the study area is mature karst, with abundant sinkholes, sinking streams, karst windows, and springs. Land surfaces are gently rolling, except on the steep rims of scattered deep sinkholes, pro-

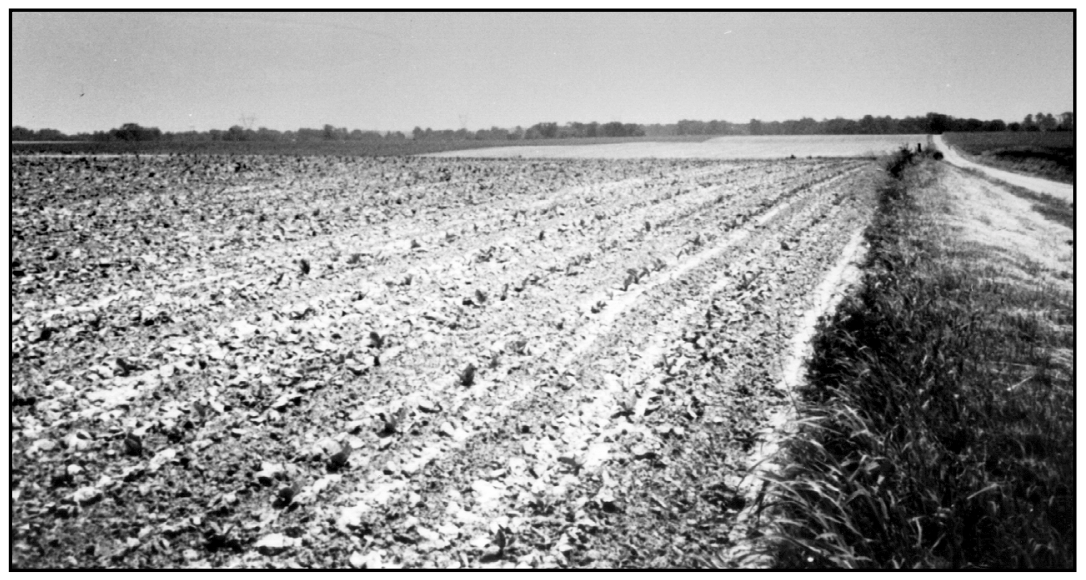

Figure 2. Example of a large crop field in the study area. viding excellent conditions for large-scale farming. Land use in the basin is almost entirely agricultural. The primary row crops are corn, wheat, and soybeans, planted in a 2-year rotation (Fig. 2). Minor crops include hay, tobacco, milo, rye, and barley. Livestock production includes beef (1,300 to 1,400 head) and dairy cattle (200 to 300 head) and swine (1,000 to 1,200 head).

\section{Geology and Hydrogeology}

The geology of the area was mapped by Rainey (1965), Shawe (1966a, b), and Miller (1968). Only two mapped units, the St. Louis Limestone and the overlying Ste. Genevieve Limestone, occur at the surface in the basin. Exposures of these units are generally poor. The upper $70 \mathrm{ft}(21 \mathrm{~m})$ of the St. Louis Limestone is exposed along stream channels and in deep sinkholes in the southern end of the basin. Although the St. Louis is a relatively pure, thick-bedded, oolitic to micritic limestone, it also contains thin, argillaceous-carbonate and shale beds and both bedded and nodular chert. Because

of limited outcrop and drill-hole data, the boundary between the St. Louis and the overlying Ste. Genevieve is mapped at the highest occurrence of a relatively thick and widespread horizon of chert. This unit is probably the stratigraphic equivalent of the Lost River Chert (Garland R. Dever Jr., Kentucky Geological Survey, oral commun., 1994).

The Ste. Genevieve Limestone is a very pure, thickbedded, oolitic to micritic limestone with scattered, thinbedded chert layers, primarily near its base. The lower $197 \mathrm{ft}(60 \mathrm{~m})$ of the Ste. Genevieve Limestone is exposed in the basin.

Geologic structures in the study area are modest. Strata dip gently to the northwest at $60 \mathrm{ft} / \mathrm{mi}$ $(11.4 \mathrm{~m} / \mathrm{km})$ (Fig. 3) into the Illinois Basin. No faults are mapped within the drainage basin; however, significant faulting occurs to the north, and obvious lineaments of sinkholes within and near the basin suggest the possibility of unmapped faults.

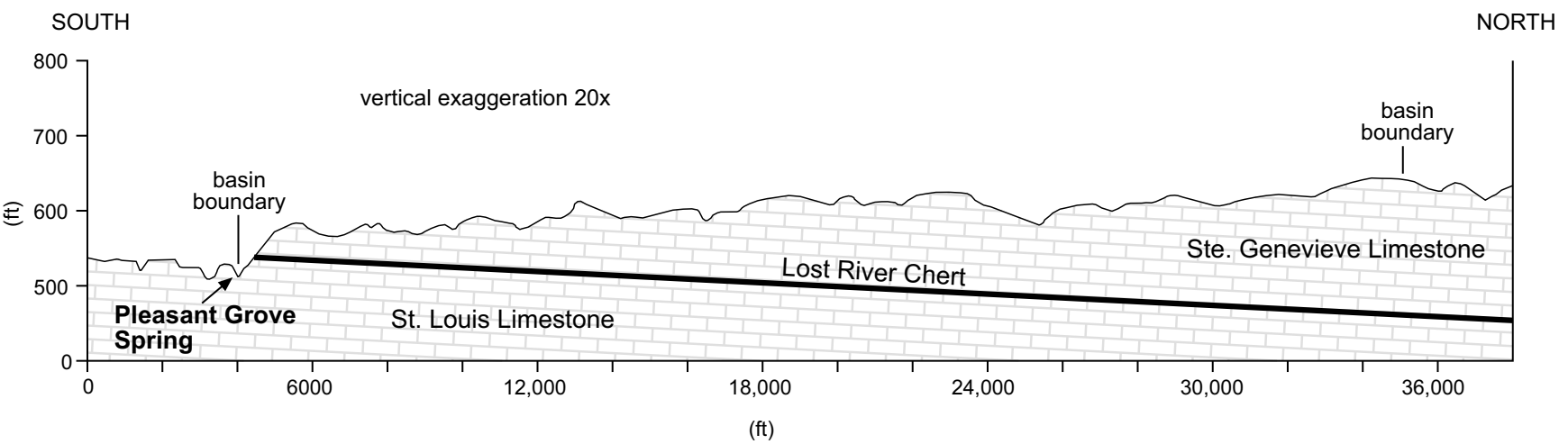

Figure 3. South-north geologic cross section of the study area showing the approximate position of the Lost River Chert (after Cupp, 1994; reprinted with permission of the author). 
Previous hydrogeologic investigations in the area are highly generalized (Brown and Lambert, 1962; Van Couvering, 1962). Pleasant Grove Spring was sampled by the U.S. Geological Survey in 1982 (Rene Garcia, written commun., 1994). Ground-water flow in the ba$\sin$ is through enlarged joints, bedding planes, and karst conduits. Flow on the surface persists in the northern end of the study area through most of the year, gradually ceasing headward as drought periods lengthen. Flow in the southern end of the basin is exclusively underground, except that scattered deep sinkholes allow access to flowing water during extreme high flow. Domestic and agricultural water supplies traditionally have come from springs and wells; some residents have recently obtained public water supplies, however-partly because of deteriorating water quality. Man-made ponds and naturally plugged sinkholes provide additional water supplies for livestock.

For the reader's convenience, the names of some karst features not commonly used are defined here. A swallow hole is an opening in a stream channel into which a stream may partially or totally sink. An estavelle functions as a swallow hole when the water table is low; quick runoff from storms sinks into the estavelle until the water table rises to the elevation of the surface. When the water table is high during prolonged rains, the estavelle acts as a spring. A blue hole is any deep clear pool of water in a karst area. The most common use of the term "blue hole" is for a spring rising from some depth under pressure. A karst window is a sinkhole with a spring on one end and a swallow hole on the other, connected by a short reach of surface-flowing water.

\section{Soils}

Soils in the basin are Pembroke-Crider association, derived from loess and limestone residuum (Dye and others, 1975). They are silt loams, moderately permeable, with deep root zones. The soils may be as much as 76 in. $(2 \mathrm{~m})$ thick to the base of the subsoil. Except where loess is preserved, the soils exhibit the terra rossa coloration typical of karst, especially in the subsoil, suggesting significant iron content. There are no reported pans (layers of semiconsolidated soil particles that retard water infiltration) in either the Pembroke or Crider.

\section{Previous Research}

The leaching of agricultural chemicals from soils or into ground water and the overland flow of soil, animal waste, and chemicals into streams in nonkarst settings have been documented for decades (Lichtenstein, 1958; Johnston and others, 1967; White and others, 1967; Hall and others, 1972; Dao and others, 1979; Thomas and Phillips, 1979; Cohen and others, 1986; Canter, 1987;
Libra, 1987; Wartenberg, 1988; Magette and others, 1988; Smith and others, 1988). The mechanisms of movement and the relative significance of leaching in various soils and agricultural settings are subjects of several papers (Thomas, 1972; Thomas and Phillips, 1979; Cohen and others, 1986; Canter, 1987; Smith and others, 1988). Studies of field runoff into streams have shown adverse impacts by agricultural chemicals where soil erosion is high (Sharpley and Syers, 1979; Baker, 1980). The transport characteristics, leaching characteristics, and degradation products of pesticides are beyond the scope of this report, and the reader is referred to the literature for details on these subjects.

None of the chemical leaching studies cited above were specifically directed toward the special hydrogeologic conditions of karst, and the presence of agricultural chemicals in karst ground water in concentrations warranting concern has only recently been questioned. Several widely published studies investigating agricultural chemicals in a karst aquifer were conducted in the Big Spring Basin, Iowa, however (Hallberg and others, 1983, 1984; Libra and others, 1986). Big Spring discharges from the Galena aquifer, which has a significant diffuseflow component characterized by fewer direct inflow points than found in most karst aquifers and relatively long residence times. Hallberg and others $(1983,1984)$ and Libra and others (1986) found nitrate in significant concentrations (flow-weighted mean of $45 \mathrm{mg} / \mathrm{L}$ as nitrate), but atrazine never exceeded $5.1 \mu \mathrm{g} / \mathrm{L}$ and averaged $0.28 \mu \mathrm{g} / \mathrm{L}$. They thought nitrate infiltration was related to diffuse recharge, whereas atrazine infiltration was induced by inflow to sinkholes and sinking streams. They also observed a seasonal cycle in nitrate concentration. Studies by Boyer and Pasquarell (1994) and Steele and Smith (1994) found a direct relationship between aquifer vulnerability, land use, and agricultural chemical concentrations. Because karst conduits can transport significant quantities of sediment, agricultural chemical adsorption on soil particles and their subsequent erosion may play a significant role in contaminant transport in karst aquifers. Therefore, karst aquifers may be doubly contaminated from direct runoff and diffuse infiltration.

Studies in Kentucky prior to 1991 on agricultural nonpoint-source pollution in karst aquifers are master's theses (Devilbiss, 1981; Tucker, 1982; Brown, 1985). Tucker (1982) found that nitrate concentrations increased during high flow and that sediment and bacteria discharges were significant. In contrast, Brown (1985) found that nitrate concentrations decreased during high flow. Both authors noted seasonal cycles in nitrate concentration.

More recent nonpoint-source pollution studies in karst basins in Kentucky include the Mammoth Cave 
Water-Quality Special Project (Meiman, 1991) and several projects sited in the Inner Blue Grass Region (Felton, 1991; Hampson, 1994; Keagy and others, 1994a, b). Felton (1991) found that nitrate concentration varied seasonally at Garretts Spring, but pesticides occurred only in very low concentrations. Hampson (1994) and Keagy and others $(1994 a, b)$ found several pesticides and nitrate in wells. Meiman (1991) correlated land use with water quality and noted the presence of triazines during spring storms and high bacteria levels in watersheds draining areas that included both agriculture and suburban development. Bacteria levels in the forested Buffalo Creek Basin in Mammoth Cave National Park, however, averaged 85 colonies per $100 \mathrm{ml}$ (col/100 ml) of fecal coliform (Joe Meiman, Mammoth Cave National Park, oral commun., 1994). Boyer and Pasquarell (1994) found mean bacteria counts of less than $1 \mathrm{col} / 100 \mathrm{ml}$ of fecal coliform in a pristine karst basin in southeastern West Virginia.

Monitoring karst springs for natural water-quality constituents to identify the source and transport mechanisms of contaminants is a well-established technique (Ashton, 1966; Atkinson, 1973; Meiman, 1985; Ogden, 1988; White, 1988). By continuously recording parameters such as water temperature and conductivity at karst springs, inferences can be made about the origin of the water carrying a sampled contaminant. For example, if the water temperature rises and the conductivity simultaneously decreases during runoff from a summer storm, the water discharging from the spring can be associated more with warm, less mineralized runoff from the precipitation. Any contaminant that increases in concentration during this period can also be associated with the runoff, whereas a contaminant that is diluted can be associated with ground water in storage in the karst aquifer. Concentrations of contaminants associated with ground-water stores can be expected to be higher during low flow (Meiman, 1985).

\section{Methodology General Strategy}

The ultimate goal of this study is to demonstrate whether a program to improve best management practices on farms overlying a karst aquifer will improve ground-water quality. This is to be evaluated by measuring changes in the quality of water discharged from Pleasant Grove Spring each year. Logistics, a limited budget, and public relations had a major influence on project design. For example, an annual census of actual pesticide application in the basin would have had both a poor response and created an atmosphere of distrust among farmers. Also, because of the size of the watershed, such a detailed survey was beyond budgetary limitations.
Changes in water quality were evaluated by following trends in mean concentrations, flow-weighted means, and annual mass flux of contaminants over several years. The total annual mass flux of suspected contaminants was estimated by multiplying discharge calculated from stage records by concentrations determined by analysis of samples. The flow-weighted mean is the total mass of a chemical discharged, divided by the total volume of water discharged. The mass flux was determined for 2 full years before BMP's were implemented to provide a basis for estimating variability in the flux. Samples were also analyzed for indicators of other sources of pollution, such as volatile organics, laundry detergent ingredients, and bacteria species. Although longer monitoring before implementation of BMP's would have been desirable, it was not practical because of cost.

Implementation of BMP's and other management practices began in the spring of 1995. Monitored changes in the quality of water discharging from Pleasant Grove Spring should become apparent during the 3-year BMP implementation period. Trends in mass flux and in the concentration of less quantifiable contaminants should indicate the success or failure of the BMP program.

\section{Assumptions}

It was assumed that (1) all ground-water discharged from the basin can be accounted for at Pleasant Grove Spring, (2) the precision of measuring mass flux on an annual basis is adequate to detect changes in water quality induced by changes in land use, (3) pesticides most commonly used in the basin are quantifiable by relatively inexpensive analytical techniques, (4) nonagricultural sources of contamination in the basin are minimal, (5) farmers would allow access to their property for monitoring and would participate in a BMP implementation program, and (6) funding would be obtained through the U.S. Department of Agriculture for implementation of the BMP program. All of these assumptions have either proved true or the exceptions have been manageable.

\section{Land-Use Mapping}

A generalized land-use assessment (Fig. 4) was prepared by the Logan County Soil Conservation Service (now called the Natural Resources Conservation Service), a branch of the U.S. Department of Agriculture (USDA). Annual land-use maps showing crops grown in the basin from 1991 through 1994 were prepared by the Kentucky Geological Survey from aerial photographs taken for the USDA Agricultural Stabilization and Conservation Service. The maps were digitized and the total crop areas were calculated using GRASS geographic information system software. 


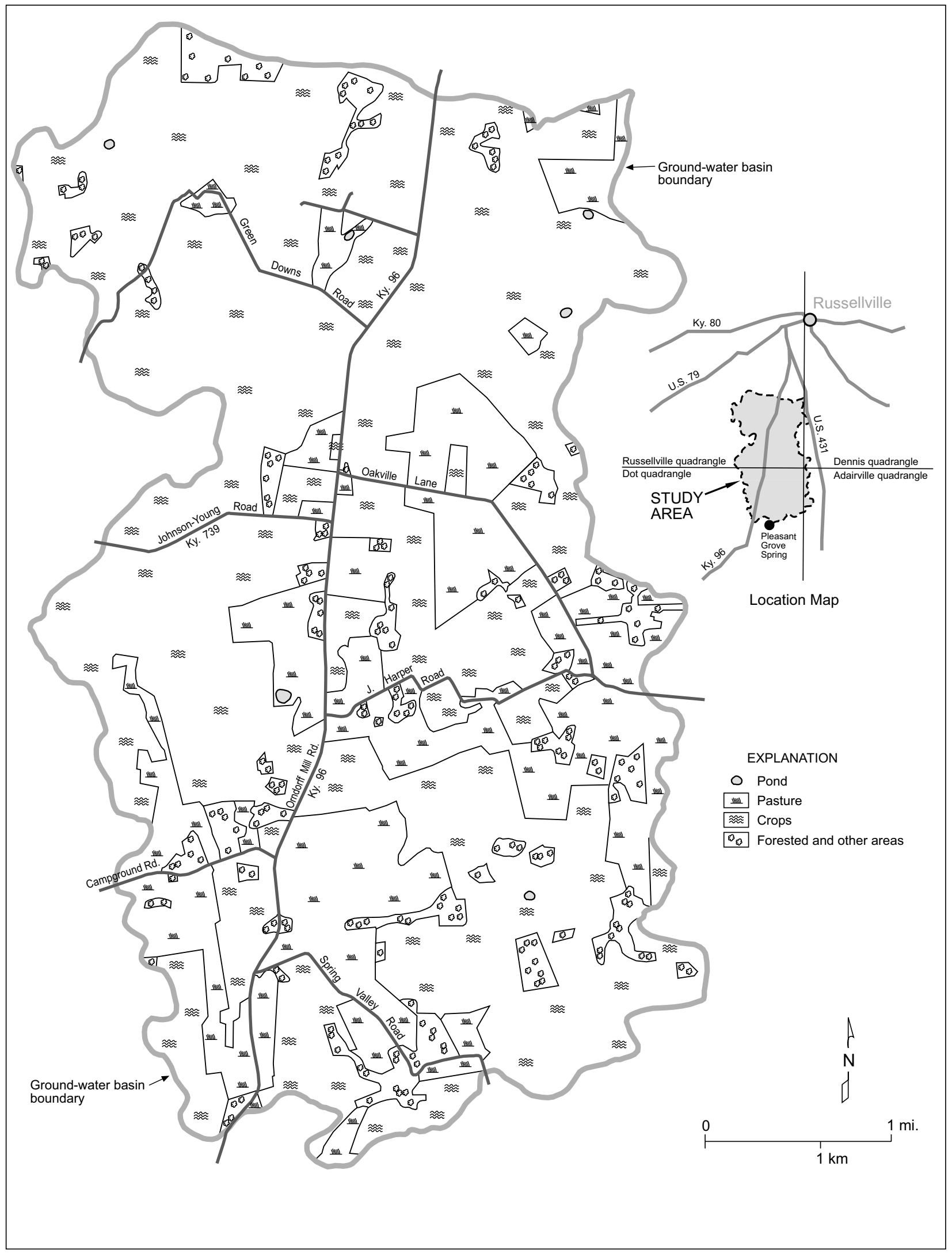

Figure 4. Generalized land use as of February 1992. 


\section{Chemical Use}

Modern agricultural practices require the use of large amounts of herbicides, insecticides, and fertilizers. Notill cropping, a method of killing noncrop plants with herbicides instead of plowing, is perhaps the most effective technique used by farmers to minimize soil erosion. Data on pesticide sales for distributors in Logan County were used as a relative indicator of trends in the use of pesticides. More than $66,000 \mathrm{lb}$ (30 metric tons) of atrazine alone is sold in Logan County annually (Ernest Collins, Kentucky Division of Pesticides, oral commun., 1993).

Chemical application rates recommended by the USDA for the South Logan County Conservation District and by the University of Kentucky College of Agriculture-Cooperative Extension Service were used to estimate percentages lost from fields. The average recommended application rate for nitrogen fertilizer for all crops in the Pleasant Grove Spring Basin is $137 \mathrm{lb} /$ acre $(154 \mathrm{~kg} /$ hectare [hc]) of nitrate-nitrogen, and the recommended rate for atrazine for corn is $2.5 \mathrm{lb} /$ acre of 80 percent active ingredient $(2.8 \mathrm{~kg} / \mathrm{hc})$. Pesticide application rates are summarized in Table 1.

\section{Ground-Water Dye Tracing}

Springs and suitable input points for ground-water dye tracing were identified during field reconnaissance. More than 70 karst features (sinking streams, caves, springs, karst windows, and estavelles) were located, and many were used during the tracing program (see Figure 4 and Plates 1 and 2 for the locations of cultural, physiographic, and hydrologic features). A boat was used to locate springs along Whippoorwill Creek and Little Whippoorwill Creek. Many features were reported by area residents, and several features were located from aerial photographs.

Ground-water basin boundaries were mapped by conducting ground-water dye traces to Pleasant Grove and surrounding springs. Standardized tracing techniques were used (Aley and Fletcher, 1976; Thrailkill and others, 1983; Jones, 1984; Davis and others, 1985; Quinlan, 1987; Mull and others, 1988). Traces used four fluorescent dyes: fluorescein (C.I. Acid Yellow 73), rhodamine WT (Acid Red 388), Diphenyl Brilliant Flavine (C.I. Direct Yellow 96), and Tinopal CBS-X (optical brightening agent 351) (Smart, 1984). Straight-line distances traced ranged from 1,500 to $28,000 \mathrm{ft}$ (457 to 8,534 $\mathrm{m})$. Fluorescein and Tinopal were introduced into swallow holes as dry powder, Direct Yellow was mixed with water in the field, and rhodamine was poured in as a concentrated solution. Direct Yellow was 20 percent active ingredient by weight, rhodamine a 20 percent solution, and other tracers were 100 percent active ingredient. Springs were monitored for dye emergence with packets of activated carbon charcoal and bleached cotton broadcloth ribbons ("bow ties") attached to concrete anchors (Currens, 1993). Dye was released from the charcoal with a solution of ammonia hydroxide, water, and 1-propanol. Inspection of the elutant and cotton bow ties (or "bugs") was done visually using an ultraviolet lamp. Weak positive traces from rhodamine or fluorescein were confirmed using a Turner Designs ${ }^{1}$ model 10 filter fluorometer. Quantitative dye traces are under way.

\section{Optical Brightener Detection}

To estimate relative concentrations of optical brightener in Pleasant Grove Spring and Leslie Page karst window, cotton fabric was mounted on frames (Thrailkill and others, 1983) and deployed in the springs for 2-week periods. The brightening agents sorb on cotton fabric and fluoresce in ultraviolet light (at wavelengths greater than $450 \mathrm{~nm}$ ). The detectors were placed in July 1993 and July and August 1994 at Pleasant Grove Spring, Leslie Page karst window, and David Dotson spring. The detectors were washed and dried and delivered to the National Park Service at Mammoth Cave, $\mathrm{Ky} .$, where they were analyzed for fluorescence using a Shimaduzu model RF5000u scanning fluorometer.

\section{Monitoring Equipment}

Monitoring equipment installed at Pleasant Grove Spring between May 20 and June 3, 1992, continuously records the quality of the discharge at 10-minute intervals (Fig. 5). A Yellow Springs Instruments (YSI) model 3800 water-quality logger records water temperature, $\mathrm{pH}$, conductivity, dissolved oxygen, turbidity, and barometric pressure. The logger also records a point-discharge velocity from a Marsh-McBirney 201-D water-flow meter. A Telog model 2109 water-level recorder independently records the stage. A portable Isco, Inc., automatic water sampler has also been installed to collect storm samples. A model 2900 Isco water sampler collects samples at closely spaced, regular intervals, generally 12 hours. Monitoring equipment at each of the upstream sites consists of a staff gage and Telog model 2109 e water-level recorder. Battery-powered Isco samplers are temporarily installed as needed. All of the Telog data loggers are battery powered. The YSI 3800 water-quality logger and Marsh-McBirney 201-D wa-

\footnotetext{
${ }^{1}$ The use of manufacturer and trademark names does not constitute an endorsement of the product by KGS or the University of Kentucky; these names are included for reference only.
} 


\begin{tabular}{|c|c|c|c|}
\hline Pesticide & Purpose & $\begin{array}{c}\text { Application Rate } \\
\text { Maximum per Acre }\end{array}$ & $\begin{array}{c}\text { Time of } \\
\text { Application }\end{array}$ \\
\hline atrazine & corn, pre-emergent herbicide & 2.5 lb. @ 80\% & mid-April \\
\hline butylate & corn, pre-plant herbicide & 7 pints & early April \\
\hline metolachlor & corn, pre-emergent herbicide & 2 pints & \\
\hline alachlor & corn, pre-emergent herbicide & 2 pints & \\
\hline cyanazine & corn, pre-plant herbicide & 2 quarts & April \\
\hline pendimethalin & corn, pre-emergent herbicide & 3 pints & April \\
\hline carbofuran & corn, insecticide & $5 \mathrm{lb}$. & May and June \\
\hline permethrin & soybean, insecticide & $6.8 \mathrm{oz}$. & \\
\hline linuron & soybean, pre-emergent herbicide & $1 \mathrm{lb}$. & \\
\hline trifluralin & soybean, pre-emergent herbicide & 2.25 pints & \\
\hline chlorpyrifos & soybean, insecticide & 1.5 pints & June and July \\
\hline $2,4-\mathrm{D}$ & corn, post-emergent herbicide & 1.5 pints & May and June \\
\hline endosulfan I \& II & tobacco, insecticide & & \\
\hline
\end{tabular}

ter-flow meter are normally powered by commercial line power, but have battery backup. The Isco samplers at Pleasant Grove Spring are powered by either batteries or line power.

A simple weather station was also installed at Pleasant Grove Spring. A Telog model 2107 pulse recorder records from a Rain Wise tipping bucket gage, and a Telog model 2103 ambient temperature recorder records the air temperature. A nonrecording rain gage is used as a check on the tipping bucket. Both loggers record at 10-minute intervals.

Records from all water-level recorders are nearly 100 percent complete. The overall record from the YSI 3800 logger is approximately 79 percent complete because of power outages, lightning strikes, and other minor malfunctions. The MarshMcBirney flow meter has been damaged by lightning and its cable has been damaged by objects discharging from the spring and from handling, resulting in a 60 percent complete record. The dissolved oxygen and turbidity probes have also occasionally failed or become fouled, resulting in 67 and 57 percent complete records, respectively.

\section{Discharge Measurements}

Discharge measurements were made by the partial sections method and wading (Buchanan and Somers, 1976), using a Marsh-McBirney 2000 magnetic water flow meter. Measurements were made during reconnaissance sampling to provide instantaneous discharge data to accompany ana- lytical data. Discharge measurements continue to be made at monitoring stations so that rating curves for continuous discharge calculation can be developed (Fig. 6). Discharge data for Pleasant Grove Spring were used to develop a rating curve by correlating stage observations with discharge (Fig. 7). The stage at which flow stops (gage zero flow-GZF) at Pleasant Grove Spring was determined by calculating the stage axis intercept of zero flow on an arithmetic graph of stage versus discharge; this was done because discharge has never approached zero at Pleasant Grove Spring. The GZF for

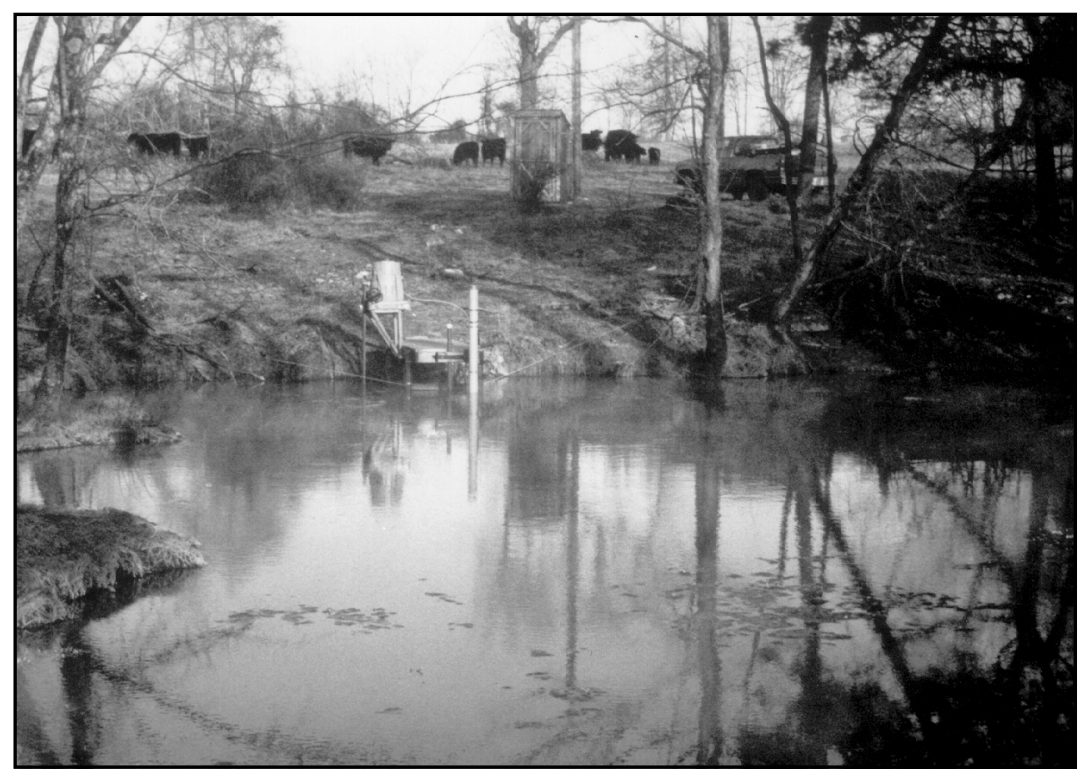

Figure 5. Instrumentation, supported by a pier, in the mouth of Pleasant Grove Spring. Storage shed housing data loggers and other equipment is in the background. 


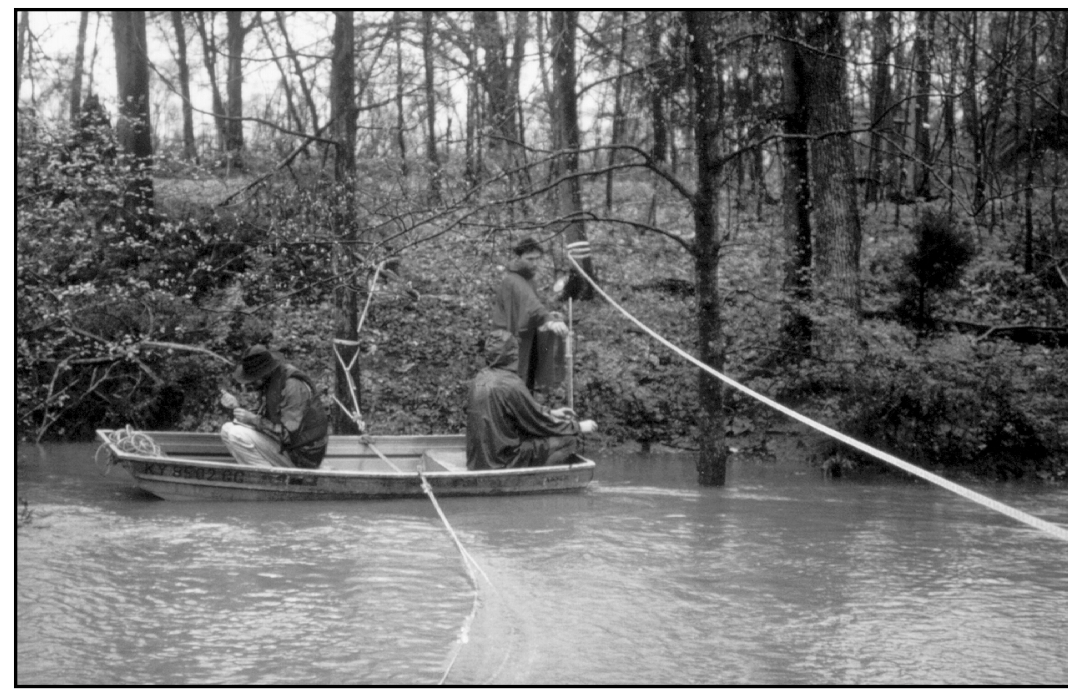

Figure 6. Discharge measurements being made at Pleasant Grove Spring during the May 1993 high-flow event.

other sites was either determined in the same manner or was directly observed, if possible. The continuous stage record was then used to calculate a continuous discharge hydrograph. A similar process was also used for Leslie Page karst window. The discharge-stage relationship is controlled by the channel cross section at all stations except Upper Pleasant Grove Creek, where a box culvert supporting Johnson-Young Road controls the relationship. In June 1994 beavers built a dam on Upper Pleasant Grove Creek a few hundred feet downstream of the box culvert, which changed the control of the stage-discharge relationship. This situation required replacement of the earlier discharge and stage observations. Because the George Delaney swallow hole site is normally dry from July to November each year, the collection of sufficient discharge data to develop a rating curve has been delayed. Discharge measurements are reported in Appendix A.

\section{Sample-Collection Methods}

Water samples were collected using field protocols and quality-control practices of the U.S. Geological Survey (1982) and the U.S. Environmental Protection Agency (EPA) (1983). All samples collected by dipping were with the mouth of the bottle facing upstream (ASTM D3370). All sample containers were new, and intermediate containers were not used. All sampling equipment was cleaned in compliance with EPA method 507 (revision 2.0, paragraph 4.1.1) (U.S. EPA, 1989). The equipment was washed with tap water and laboratory detergent, rinsed with tap water, rinsed three times with distilled water, and final-rinsed with reagent-grade acetone instead of oven drying. Sample containers and preservation methods are detailed in Appendix B.
For the reconnaissance samples and other samples collected for comprehensive analysis, conductivity, $\mathrm{pH}$, and temperature were measured in the field, and $\mathrm{pH}$ and conductivity were also measured in the laboratory. Because of the logistical constraints imposed by the simultaneous collection of bacteria samples and discharge data, only samples for total analysis were collected during the reconnaissance sampling.

The collection of samples for dissolved constituents, including pesticides, was begun in October 1993 at Pleasant Grove Spring. These samples were collected with a peristaltic pump directly from the rise pool of the spring; intermediate containers were not used. Samples for analysis of dissolved constituents were pumped through a stainless steel and Teflon filter stand equipped with Teflon tubing. The stand and tubing were assembled and sealed immediately after cleaning for later transport to the field.

High-flow samples were collected by an Isco model 3700 automatic sampler directly from the rise pool of the spring. The sampler and its containers were decontaminated before each field deployment, according to EPA method 507. Intake tubing and screen were assembled and sealed for transport immediately after cleaning. Upon installation, each sampler was purged with water from the sample site, and intake lines were left empty. Samplers were activated by a water-pres-

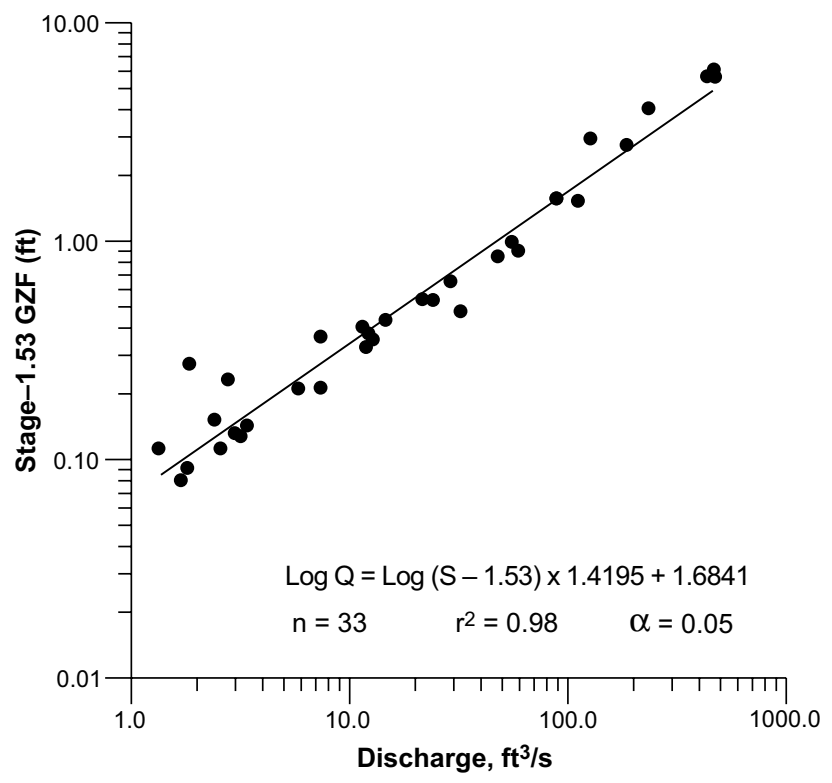

Figure 7. Stage versus discharge rating curve for Pleasant Grove Spring. 
ence sensor. The sampler is programmed to rinse the intake lines three times when activated, before filling the sample container.

Wells were not systematically sampled, but a few samples were collected from wells as opportunities arose. Samples from domestic wells in use were collected directly into the sample container from the faucet nearest the well after pumping until temperature and conductivity stabilized. Samples from abandoned wells were collected with a bailer after purging with a portable pump.

Rainwater samples were collected for pesticide and nitrate analysis using a ring stand and glass funnels deployed away from trees and buildings. An 8-in.-diameter glass funnel emptied into a 4-in.-diameter funnel covered with a stainless-steel screen. The spout of the smaller funnel fit tightly into the 2-cm-diameter mouth of a sample bottle, in order to minimize evaporation.

\section{Sampling Schedule}

The sampling schedule initially consisted of synoptic monthly sampling, but was later modified to emphasize storm samples at selected sites. The phase I synoptic samples, analyzed for a comprehensive suite of constituents, were collected at six sites for water-quality reconnaissance. These sites are Pleasant Grove Spring, Spring Valley karst window, George Delaney swallow hole, Shackelford Spring, The Canyon karst window, and Flowers estavelle (Thad Flowers blue hole) (Plate 1). During some months, sites were not sampled because they were dry or because ponding from flooding prevented access to moving water. Samples were not collected on other occasions because of holiday schedules at laboratories and other logistical issues. During the no-cost extension periods between project phases (April 1993-September 1993 and September 1994-March 1995), sampling schedules were modified to minimize cost.

During phase II, the sampling schedule emphasized accounting for mass flux of constituents at Pleasant Grove Spring and at a new site, Leslie Page karst window. Leslie Page karst window was added as a monitoring site in the spring of 1993 to replace The Canyon karst window as a small sub-basin monitoring station. One other new site, Joe Harper water well, was added to monitor for the area of origin for pollutants. Joe Harper water well is a natural estavelle that has been lined with masonry for use as a well. It is near The Canyon karst window and is only sampled when flowing water in The Canyon karst window is inaccessible because of flooding.

Also during phase II, sampling at two of the phase I sites (Shackelford Spring and Thad Flowers blue hole) was discontinued and sampling at The Canyon karst window was temporarily suspended. A monitoring station on Upper Pleasant Grove Creek at Johnson-Young Road, 2,500 ft $(760 \mathrm{~m})$ downstream of Shackelford Spring, replaced Shackelford Spring as a monitoring site. Shackelford Spring was abandoned because it was in a remote location, its discharge was difficult to measure accurately, the site was a poor location for a continuous stage recorder, and the property owner was reluctant to continue to allow access. Similar problems were encountered at Thad Flowers blue hole. The Upper Pleasant Grove Creek site is on the public right-of-way and has the benefit of a bridge to control discharge. Also, in contrast to Shackelford Spring, which represents ground-water discharge from the headwaters area, Upper Pleasant Grove Creek represents the quality and quantity of most discharge from the area.

Monthly comprehensive sampling continued at Pleasant Grove Spring during phase II, but other samples were collected more frequently for less exhaustive analysis. Base-flow grab samples were collected during low flow at Pleasant Grove Spring on a schedule that varied from biweekly in the spring to monthly in the late summer, fall, and winter. Event samples, which were analyzed for total suspended solids and total dissolved solids in addition to the base-flow constituents, were collected at Pleasant Grove Spring during high flow. Event samples were initially collected every 20 minutes, then over incrementally longer periods as the stage receded. An attempt was made to collect a suite of event samples for every storm causing a $0.1 \mathrm{ft}(3 \mathrm{~cm})$ or greater rise in stage at Pleasant Grove Spring from mid-March to July 1995. Samples for bacteria, ammonia, nitrite, and orthophosphate were not collected during storms because samples had to be left in the Isco samplers longer than the holding times recommended for these constituents. Failure of the Isco samplers because of power outages, premature activation of the sampler, and flooding of the sampler caused some highflow events to be missed.

Sampling at Leslie Page karst window included quarterly comprehensive, base-flow, and event samples. Stage response at Leslie Page karst window was frequently so minor that the Isco sampler failed to detect the rise in stage and did not collect samples. This sampler was reprogrammed to collect samples every 12 hours.

Rainwater samples were collected in May and June of 1992, 1993, and 1994. Deployment periods for the rain sampler were as long as a month, but most were deployed for specific storms and were retrieved within 12 hours.

Generally, samples were collected from domestic wells only on an ad hoc basis, in response to requests from owners. One abandoned domestic well called 
Miller School House well (see Plate 2, Kentucky Division of Water identification number AKGW-17158), on the east-central margin of the basin near Oakville, was added as a control sampling point that was unlikely to intercept any agricultural chemicals. The well is cased with steel from ground level to the top of bedrock and is approximately $84 \mathrm{ft}(26 \mathrm{~m})$ deep. The only protection from surface contamination is a limestone rock laid over the hole.

\section{Analytical Methods and Quality Control}

All major-ion and pesticide analyses were performed at the Kentucky Geological Survey's water-quality laboratory. Comprehensive samples were analyzed for major ions, nutrients, and pesticides. Event samples were analyzed for nitrate, total dissolved solids, total suspended solids, and pesticides by enzyme-linked immunosorbent assay (ELISA). Base-flow samples were analyzed for nitrate and pesticides by ELISA. Precipitation samples were analyzed by gas chromatography (GC) or ELISA, depending on available sample volume. Cations were determined on an inductively coupled plasma spectrometer, and anions were determined on an ion chromatograph. Total alkalinity was determined in the laboratory with an autotitrator. Pesticide analyses were made on a gas chromatograph using EPA methods 507 and 508. The Ogden Environmental Laboratory at Western Kentucky University in Bowling Green conducted bacterial determinations. Bacteria counts were determined by multiple-tube fermentation and mostprobable-number statistical estimation until May 1992, when the laboratory changed to membrane filter techniques (EPA methods 9222D and 9230B). Samples collected for streptococci speciation were filtered and cultured by Ogden laboratory and sent to the University of Kentucky College of Agriculture for speciation. Volatile organic compounds were determined by the water-quality laboratory at Heidelberg College, Tiffin, Ohio. See Appendix B for a complete list of analytical methods, detection limits, and discussion of the ELISA method.

Field equipment was checked for proper operation before each field trip. Conductivity and $\mathrm{pH}$ meters were calibrated or compared with standards at the beginning of each sampling day. Permanently installed water-quality meters were calibrated monthly. The MarshMcBirney flow meters are factory calibrated and cannot be adjusted or calibrated by the user. All monitoring equipment is cleaned and checked monthly to ensure proper operation.

Quality-control samples included equipment blanks, trip blanks, and field blanks. Pesticide analyses were made in replicate by the laboratory as part of its internal quality assurance. Duplicate samples for nitrate and pesticide analysis were collected monthly from Pleasant Grove Spring beginning in 1994.

\section{Quantification of ELISA}

Pesticide analysis by ELISA was chosen because the number of analyses needed for mass-flux estimation was cost-prohibitive and logistically impractical by gas chromatograph. The validity of quantifying pesticide concentrations with ELISA was evaluated by analyzing split samples by GC and ELISA for triazines, alachlor, and metolachlor. Analyses for other pesticides for which ELISA kits were available (carbofuran and 2,4-D) were not compared with GC analyses because GC methods were not available. For 29 ground-water samples with atrazine concentrations determined by GC to be equal to or above the GC detection limit $(0.3 \mu \mathrm{g} / \mathrm{L})$, the correlation coefficient $\left(\mathrm{r}^{2}\right)$ was 0.95 for triazines (determined by ELISA) versus atrazine (determined by GC) (Fig. 8). The detection limit for triazines by ELISA was $0.046 \mu \mathrm{g} / \mathrm{L}$. Another correlation was calculated for samples with atrazine concentrations between 0.3 and $1 \mu \mathrm{g} / \mathrm{L}$ for both GC and ELISA. Although the correlation was not as good as with higher concentrations $\left(\mathrm{r}^{2}=0.91\right)$, it still suggests that the ELISA method for detecting triazines can be used quantitatively to detect atrazine at concentrations above $0.3 \mu \mathrm{g} / \mathrm{L}$, but may be valid only as a presence-absence test below that concentration. Thurman and others (1990) found a correlation of 0.99 for ground water spiked with atrazine. For all samples for which both determinations were made, the

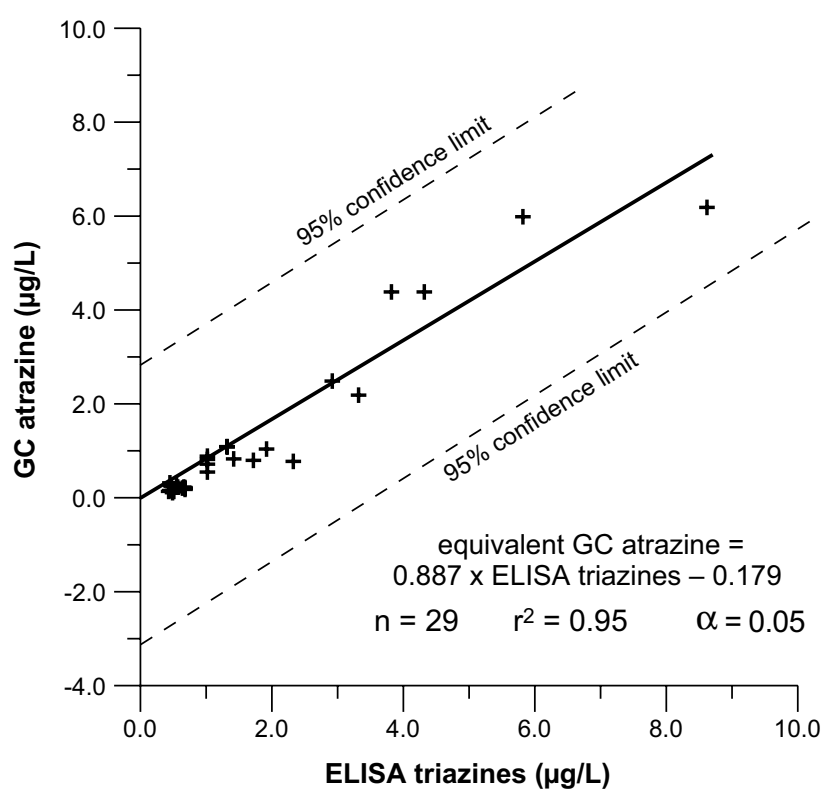

Figure 8. Cross-plot of triazine determinations by ELISA versus atrazine determinations by GC. 
concentration of triazines determined by ELISA was nearly identical to that of atrazine determined by GC. This is because nearly all samples analyzed by GC have shown below-detection concentrations of cyanazine and simazine. Furthermore, the manufacturer of the ELISA kits reported that low levels of cyanazine and simazine are largely undetected by the triazine kit (Ohmicron Corp., 1991). The correlation coefficient for 19 metolachlor samples with concentrations ranging from $0.05 \mu \mathrm{g} / \mathrm{L}$ (the GC detection limit) to $8 \mu \mathrm{g} / \mathrm{L}$ was 0.80 and is significant at the 95 percent confidence level (Fig. 9). However, work under way at the Kentucky Geological Survey shows that alachlor determined by ELISA correlates poorly with alachlor determined by GC $\left(r^{2}=0.34\right)$. These results suggest that the ELISA method can be used quantitatively for atrazine and metolachlor. Error bars are not shown on concentration graphs because they obscure the location of data points at the scale needed to show the range of concentrations. Standard deviation for laboratory replicates of atrazine is 0.063 at $1.0 \mu \mathrm{g} / \mathrm{L}$ and 0.13 for metolachlor at $1.30 \mu \mathrm{g} / \mathrm{L}$.

\section{Mass-Flux Calculation}

The mass flux of agricultural chemicals discharging from Pleasant Grove Spring was estimated by multiplying the volume of water discharging during a 10minute interval by the concentration of monitored constituents in the most recent sample, and summing the 10-minute interval flux values between samples:

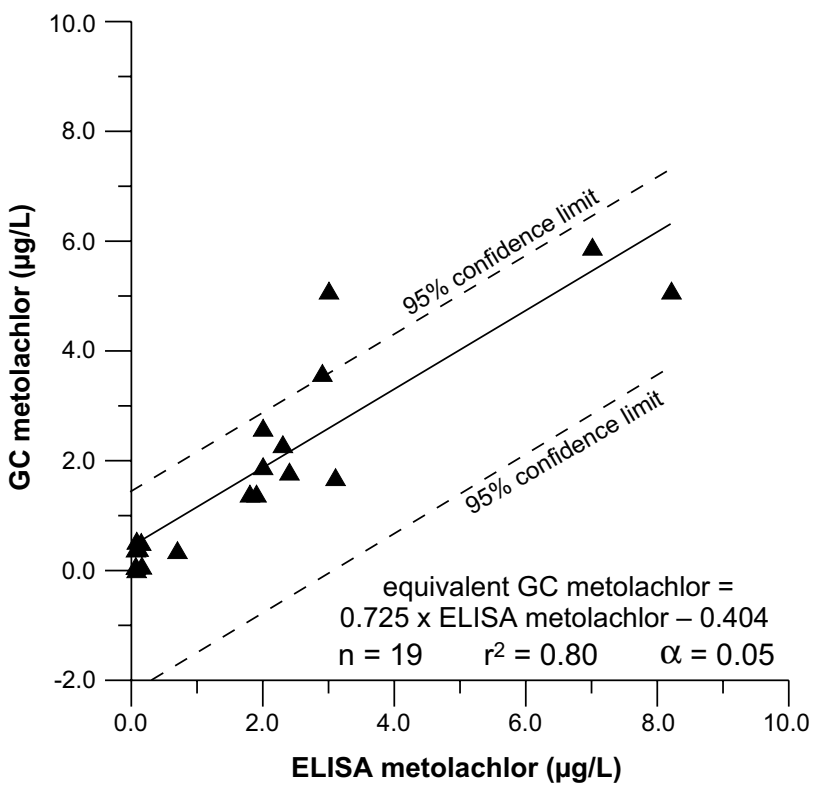

Figure 9. Cross-plot of metolachlor determinations by ELISA versus metolachlor determinations by GC.
$\mathrm{MF}_{10 \min }=\mathrm{Q} \times 600 \mathrm{~s} \times \mathrm{PC}$

$\mathrm{AMF}=\operatorname{sum}\left(\mathrm{MF}_{10 \mathrm{~min}}\right)$

Where:

$\mathrm{MF}_{10 \min }=$ mass flux during a 10-minute interval

$\mathrm{Q}=$ discharge in liters per second

$\mathrm{PC}=$ prevailing constituent concentration

$\mathrm{AMF}=$ the annual mass flux

sum=the summation of 10-minute mass flux increments over the water year.

Nitrate-nitrogen concentrations were used directly. An equivalent atrazine concentration was calculated from triazine determinations using the regression of triazines determined by ELISA and atrazine determined by GC, discussed above. A metolachlor-equivalent flux was estimated in the same way. Flux for suspended sediment has not been estimated because of fouling and failure of the turbidity probe. A flux for alachlor was not estimated because of the poor correlation between GC and ELISA. A carbofuran flux was estimated using ELISA analyses, but its significance is unknown because there was no GC method available at KGS for determining carbofuran concentration.

\section{Results}

\section{Land-Use Mapping}

Land-use mapping shows that nearly 70 percent of the basin is crop land and another 22 percent is pasture. Between 3,000 and 3,700 acres (1,200 and 1,500 hc) of corn is grown annually. Industrial activity is absent from the basin; the only nonagricultural business is a small tractor and automobile repair garage. There is no urban development, and suburban development is limited to roughly 30 homes in the rural community of Oakville and scattered farm housing. No rail lines and only one state highway cross the basin, and there is little industrial traffic on the roads. There is no active petroleum production in the basin, and a review of the Kentucky Oil and Gas Data Repository at the Kentucky Geological Survey revealed very limited historical activity.

\section{Precipitation Analyses}

Of seven rain samples collected, only a few contained measurable amounts of pesticides (Appendix C). Sample RAIN0002, collected from June 17 to July 7, 1992, contained $2.8 \mu \mathrm{g} / \mathrm{L}$ of butylate, but triazines, atrazine, and carbofuran were not detected. Concentrations of alachlor and metolachlor in the July 7 sample did not exceed $0.18 \mu \mathrm{g} / \mathrm{L}$, determined by ELISA. The July 7 sample probably was contaminated by an insect found in the bottle. The greatest concentration of triazines was from a sample collected between May 19 and June 1, 1993 $(0.93 \mu \mathrm{g} / \mathrm{L})$. Another sample collected between 16:00 
May 18 and 08:55 May 19, 1993, contained 0.68 $\mu \mathrm{g} / \mathrm{L}$ of triazines. These data may reflect dusty conditions caused by the unusually dry weather in the spring of 1993 . Triazine concentrations averaged $0.23 \mu \mathrm{g} / \mathrm{L}$. Nitrate-nitrogen was also determined for three samples collected in 1993 and 1994, and all measured less than $1 \mathrm{mg} / \mathrm{L}$.

\section{Hydrogeology}

Ground-Water Basin Boundary Mapping. Fortyseven ground-water dye traces were conducted through March 1994 and are summarized in Appendix D. The watershed boundary was defined, and the area of the basin is estimated to cover 10,054 acres $(4,069$ hc). Plate 1 illustrates the basin boundary, the location of major karst features, and ground-water dye-trace vectors. The ground-water basin boundary is roughly consistent with the apparent topographic divide, except in the vicinity of Oakville, where sinkholes are closely spaced.

In addition to identifying the basin boundary, dye tracing resulted in other findings that are significant to understanding the hydrogeology of the basin. The Canyon karst window was initially chosen to represent a hypothesized small sub-basin. Dye introduced into Piper estavelle, while it was acting as a swallow hole, was detected at The Canyon karst window, suggesting influence by the larger basin. This trace and traces from Miller sinkhole and Harper karst window revealed that the catchment area of The Canyon karst window was too large to use as a sub-basin.

Another problem area lies outside of the northwest boundary of the basin. Sinkholes east of Miles karst window encroach on Upper Pleasant Grove Creek. According to area residents, much of the area north of Johnson-Young Road was marshy before drainage was channelized. The rim of the sinkhole nearest the nowchannelized Upper Pleasant Grove Creek lies less than $10 \mathrm{ft}(3 \mathrm{~m})$ above the normal stage of the creek and within $200 \mathrm{ft}(60 \mathrm{~m})$ of the channel. Water from Upper Pleasant Grove Creek may spill into the sinkhole during extreme high flow, although this has not been observed by KGS personnel. Dye introduced into this normally dry sinkhole was detected at Hickory Hill karst window and Dawson Spring, outside of the Pleasant Grove Basin (Plate 1). To determine if flow from Upper Pleasant Grove Creek was diverted outside the basin, $2 \mathrm{~L}$ of rhodamine WT was introduced at dusk (to prevent photodegradation) into Upper Pleasant Grove Creek, during moderate flow, in the vicinity of Green Downs Road. Although all known springs along Whippoorwill Creek were monitored, dye was only detected at Pleasant Grove Spring, indicating no leakage during moderate or lower flows.

Flow duration along Upper Pleasant Grove Creek is highly seasonal. Each year Piper estavelle acts as a spring from November through May, and the combined flow from it, Shackelford Spring, and Upper Pleasant Grove Creek continues south to George Delaney swallow hole. South of George Delaney swallow hole the now-abandoned channel of a surface-flowing Pleasant Grove Creek is dry except during high flow. Johnson swallow hole, at the southern end of the abandoned channel, receives flow when the intake capacity of George Delaney swallow hole is exceeded. Flow into Johnson swallow hole was traced to Pleasant Grove Spring. During extremely high flow, however, the inflow capacity of Johnson swallow hole is also exceeded, and water discharges overland to Pleasant Grove Creek, downstream of Pleasant Grove Spring. Johnson swallow hole, George Delaney swallow hole, and Piper estavelle, along with numerous minor swallow holes, form a headward-retreating series of swallow holes diverting the surface reaches of Upper Pleasant Grove Creek underground to Pleasant Grove Spring.

Only one quantitative trace has been completed. Because this trace was the first trial to determine a rough travel time, no attempt was made to estimate the centroid of the breakthrough curve or calculate the dye recovery. Rhodamine WT (500 ml, 20 percent solution) was introduced into George Delaney swallow hole under low-flow conditions (discharge $3.3 \mathrm{ft}^{3} / \mathrm{s}\left[0.1 \mathrm{~cm}^{3} / \mathrm{s}\right]$ at Pleasant Grove Spring). Dye was detected 23:40 hours after injection, and concentrations peaked after 25:50 hours. Straight-line flow velocity under these conditions is roughly $0.14 \mathrm{ft} / \mathrm{s}(0.04 \mathrm{~m} / \mathrm{s})$ but is expected to be much faster during high flow.

Plate 1 shows the location of King sinkhole, but with no trace vectors leading from it. Four attempts were made to trace from this sinkhole, without success. Because the trace was deemed lower priority than others being conducted at the same time, Tinopal CBS- $X$ was used for the first three attempts. Another trace, conducted earlier in the dye-tracing program, approximately 1,000 ft (300 m) southeast of King sinkhole, in a poorly draining sinkhole, was also lost. After these traces were lost, a second boat reconnaissance was made on Whippoorwill Creek to look for a missed spring. Although some suspicious channel reaches were noted, no new springs were found. A fourth trace was attempted from King sinkhole using fluorescein, but it also failed, despite more than 25 springs and bridge crossings being monitored. Although no field evidence could be found suggesting a hidden spring, the lost traces are thought to have flowed to Whippoorwill Creek. The missing spring may rise in mid-channel of Whippoorwill Creek between Burchette Spring and Claude Blick Spring. None of the traces flowed to Pleasant Grove Spring. 
To supplement the ground-water dye-trace data, a potentiometric map of the study area was prepared (Plate 2). Between June and September of 1993, more than 100 domestic wells were inventoried (Appendix E), and 30 water-level measurements were obtained (Cupp, 1994). The sparse number of water-level observations made the placement of some potentiometric contours subjective. As a broad generalization, contours in the headwaters area of the map are more widely spaced than in the conduit-flow area. The area between George Delaney swallow hole and Johnson swallow hole is problematical: the potentiometric surface and the positioning of flow routes are open to alternative interpretation. The dye trace from Johnson swallow hole did not travel through Spring Valley karst window; thus, the location of the confluence of Johnson swallow hole's conduit with the conduit from Spring Valley karst window to Pleasant Grove Spring is subjective. The confluence may be much closer to Pleasant Grove Spring, and the flow route nearly parallel to the relic valley from Johnson swallow hole to Pleasant Grove Creek. In this case, the $510-\mathrm{ft}(155-\mathrm{m})$ potentiometric contour along the flow route from George Delaney swallow hole to Pleasant Grove Spring would be closer to the conduit. A second, narrow potentiometric low would extend from just south of George Delaney swallow hole, south to Johnson swallow hole, then to Pleasant Grove Spring. The watershed boundary between Johnson swallow hole and Pleasant Grove Spring would remain unchanged, however, because field inspection of the topography verifies that runoff from this area must bypass Pleasant Grove Spring.

Ground-Water Flow Regimes. Two ground-water flow regimes are hypothesized for the basin. An area in the northern, headwaters part of the basin is characterized by slower flow rates than in the southern part (Plate 2). Although karstic, the headwaters area exhibits characteristics suggestive of a more diffuse, slow-flow regime. The gradient of the potentiometric surface in the headwaters area is slightly more gradual than in the conduit, fast-flow-dominated area. Dye-trace travel times in the headwaters area were less than $0.005 \mathrm{ft} / \mathrm{s}$ $(0.002 \mathrm{~m} / \mathrm{s})$. The water table in the slow-flow area is near ground level, as evidenced by marshes, common sinkhole ponds, and blue holes (local name for shallow sinkholes intersecting the water table, many of which function as estavelles). Wells in the area encounter water at shallow depths, typically less than $30 \mathrm{ft}(9 \mathrm{~m})$. Springs in this area are relatively small (with flow rates ranging from 0.5 to a peak of $5 \mathrm{ft}^{3} / \mathrm{s}$ [0.05 to $\left.0.5 \mathrm{~m}^{3} / \mathrm{s}\right]$ ) and empty into surface drainage that sinks again as flow approaches the southern end of the basin.
Ground water in the southern part of the basin flows rapidly through large, efficient caves. Qualitative dyetrace travel times exceed $0.02 \mathrm{ft} / \mathrm{s}(0.006 \mathrm{~m} / \mathrm{s})$, indicating substantially higher underground-stream flow velocities than in the slow-flow area of the watershed. Springs in the fast (conduit) flow regime have significant increases in discharge and become turbid within a few hours of a major storm. Flow rates at Pleasant Grove Spring range from as little as $1.5 \mathrm{ft}^{3} / \mathrm{s}(42 \mathrm{~L} / \mathrm{s})$ during base flow to several hundred cubic feet per second (thousands of liters per second) during a major storm.

The slow (diffuse) flow regime is probably the result of a shallower hydraulic gradient. Low gradients in carbonate aquifers lead to relatively uniform dissolution along many joints and bedding planes, rather than concentrated solution along a headward-migrating conduit. The lower gradient could be caused by either or both of two hydrologic factors. First, the slow-flow area could be less maturely karstified because insufficient time has elapsed since Pleasant Grove Spring developed for headward progression of conduits to reach the area. However, because karst development in the Pennyroyal Region has been in progress for as long as 10 million years (Palmer, 1981), a lack of sufficient time seems unlikely. Second, an insoluble cherty zone could be retarding conduit enlargement along its outcrop. Flow to the south would be inhibited as it passes through constricted solutional openings in the carbonate rock between nodules of the nearly insoluble chert barrier. Numerous small springs emerge above this horizon, and streams sink a few hundred feet downsection of its outcrop. The retarding horizon is probably the Lost River Chert (Crawford, 1986).

Several features in the basin function as estavelles. Piper estavelle, Thad Flowers blue hole or estavelle, and Wheatfield estavelle have all changed function from springs to swallow holes sometime during the study period. Many unnamed karst features in the study area also act as estavelles. Locally, both rise-pool springs and estavelles are called blue holes (Thad Flowers blue hole, for example). Water collects in the outlet of Thad Flowers blue hole when the water table is too low for the feature to discharge but high enough to submerge the outlet. Similar conditions apply to Joe Harper water well, which discharges or accepts inflow depending on ground-water stage.

The alignment of sinkholes, the bearing of groundwater dye-trace vectors, and the orientation of passages in mapped caves (Mylroie, 1984) suggest ground water flows downgradient but parallel to the local strike until it reaches a breach in a resistant bed. At this point flow changes direction toward the local base level, Red River. Because the regional strike trends northeast-southwest 
and the Red River is due south of the basin, a trellised drainage pattern has developed.

\section{Ground-Water Quality}

Selected analytical results for all samples are presented in Appendices C, F, G, H, I, and J. Analyses consistently reporting concentrations below detection limits or maximum contaminant levels are not included. Those data are available through the Kentucky Geological Survey's Kentucky Ground-Water Data Repository. In order to develop a consistent format for future reports, the data in the appendices are presented as water-year annual summaries (October 1 through September 30). Summaries of descriptive statistics for each water year are also presented, but their significance as characteris- tic of the ground-water quality during any given year should be considered with caution. The effects of "aliasing" (the phenomenon in which a high-frequency trend can be interpreted as a low-frequency trend because the sampling was too infrequent to characterize the high-frequency trend) and variable temporal spacing of samples has a major impact on the representative validity of the statistics. Table 2 summarizes standards for drinking water, which are commonly used as criteria for evaluating the quality of ground water.

Basinwide, ground-water temperatures average $14.5^{\circ} \mathrm{C}$, typical of Pleasant Grove Spring (Appendix F). Conductivities observed in the basin range from 744 microSiemens $(\mu S)$ at Pleasant Grove Spring to only $20 \mu \mathrm{S}$ at Leslie Page karst window. The $\mathrm{pH}$ of water in

Table 2. Maximum permissible contaminant levels for drinking water, determined by the EPA, for constituents analyzed in water samples collected from the Pleasant Grove Spring area.

\begin{tabular}{|c|c|c|c|}
\hline Analyte & Standard* & $\begin{array}{c}\text { Maximum } \\
\text { Contaminant } \\
\text { Level }\end{array}$ & Frequency or Comment \\
\hline \multicolumn{4}{|l|}{ INORGANICS } \\
\hline Arsenic & Primary & $0.05 \mathrm{mg} / \mathrm{L}$ & Annually for surface water \\
\hline Barium & Primary & $2.0 \mathrm{mg} / \mathrm{L}$ & Annually for surface water \\
\hline Chromium & Primary & $0.1 \mathrm{mg} / \mathrm{L}$ & Annually for surface water \\
\hline Copper & Primary & $1.3 \mathrm{mg} / \mathrm{L}$ & Variable \\
\hline Lead & Primary & $0.015 \mathrm{mg} / \mathrm{L}$ & Variable \\
\hline Nickel & Primary & $0.1 \mathrm{mg} / \mathrm{L}$ & Annually for surface water \\
\hline Nitrate-N & Primary & $10 \mathrm{mg} / \mathrm{L}$ & Variable \\
\hline Nitrite-N & Primary & $1.0 \mathrm{mg} / \mathrm{L}$ & Variable \\
\hline Manganese & Secondary & $0.05 \mathrm{mg} / \mathrm{L}$ & Annually for surface water \\
\hline Fluoride & Secondary & $2.0 \mathrm{mg} / \mathrm{L}$ & Variable \\
\hline Iron & Secondary & $0.3 \mathrm{mg} / \mathrm{L}$ & Annually for surface water \\
\hline Sulfate & Secondary & $250 \mathrm{mg} / \mathrm{L}$ & Annually for surface water \\
\hline Chloride & Secondary & $250 \mathrm{mg} / \mathrm{L}$ & Annually for surface water \\
\hline Total dissolved solids & Secondary & $500 \mathrm{mg} / \mathrm{L}$ & Annually for surface water \\
\hline Zinc & Secondary & $5 \mathrm{mg} / \mathrm{L}$ & Annually for surface water \\
\hline \multicolumn{4}{|l|}{ BACTERIA } \\
\hline Total coli & Primary & $1 \mathrm{col} / 100 \mathrm{ml}$ & 1 sample in 40 per month \\
\hline Total coli & Supply & $2,000 \mathrm{col} / 100 \mathrm{ml}$ & \\
\hline \multicolumn{4}{|l|}{ PESTICIDES } \\
\hline Alachlor & Primary & $0.002 \mathrm{mg} / \mathrm{L}$ & Annually for surface water \\
\hline Atrazine & Primary & $0.003 \mathrm{mg} / \mathrm{L}$ & Annually for surface water \\
\hline Simazine & Primary & $0.004 \mathrm{mg} / \mathrm{L}$ & Annually for surface water \\
\hline Carbofuran & Primary & $0.04 \mathrm{mg} / \mathrm{L}$ & Annually for surface water \\
\hline
\end{tabular}


the basin, as determined in the laboratory, ranges from 5.9 to an alkaline 8.5 , but is commonly nearly neutral.

Ground water in the basin is calcium-bicarbonate type. All the sites exhibit similar chemistry (Appendix G), but Thad Flowers blue hole has some of the widest ranges in chemistry because of its alternating function as a spring and a swallow hole. Ponded water at Thad Flowers blue hole is subject to heating and cooling, evaporation, deposition of animal feces, and oxygen loss, resulting in water quality uncharacteristic of other locations in the area. Total alkalinity ranges from an exceptionally low $37 \mathrm{mg} / \mathrm{L}\left(\right.$ as $\left.\mathrm{CaCO}_{3}\right)$ at Thad Flowers blue hole, to a high of $241 \mathrm{mg} / \mathrm{L}$ at Pleasant Grove Spring; $180 \mathrm{mg} / \mathrm{L}$ is a typical value for the basin. Total dissolved solids never exceeded $564 \mathrm{mg} / \mathrm{L}$ and commonly measure $260 \mathrm{mg} / \mathrm{L}$. However, total suspended solids may exceed 2,000 mg/L during high flow. Constituents commonly affecting ground-water quality in other regions of Kentucky are only present in dilute concentrations in the Pleasant Grove Spring Basin. The maximum total iron concentration was $7.17 \mathrm{mg} / \mathrm{L}$ at
Pleasant Grove Spring and came from a highly turbid sample collected during high flow. The typical iron value for sites in the basin is $0.5 \mathrm{mg} / \mathrm{L}$. Concentrations of all other metals listed in Table 2 were below maximum contaminate levels. Sulfate $\left(\mathrm{SO}_{4}\right)$ ranges from near the lower detection limit to $26.2 \mathrm{mg} / \mathrm{L}$, and chloride has a maximum concentration of $12.8 \mathrm{mg} / \mathrm{L}$.

Seasonal changes at Pleasant Grove and Shackelford Springs observed during reconnaissance support the dual flow-regime model indicated by dye tracing (Fig. 10). The temperature cycle at Shackelford Spring, which is thought to drain part of the diffuse-flow area, is delayed approximately 2 months compared to Pleasant Grove Spring. Shackelford Spring has a higher temperature in late summer, however, probably caused by direct solar heating of its small rise pool during low flow. Unlike temperature, the conductivity cycle is not delayed, but Shackelford Spring has a nearly constant conductivity, which narrowly ranges between 392 and $450 \mu$ S. Pleasant Grove Spring has a larger range of 136 to $744 \mu \mathrm{S}$, as determined in the field, but only 241 to

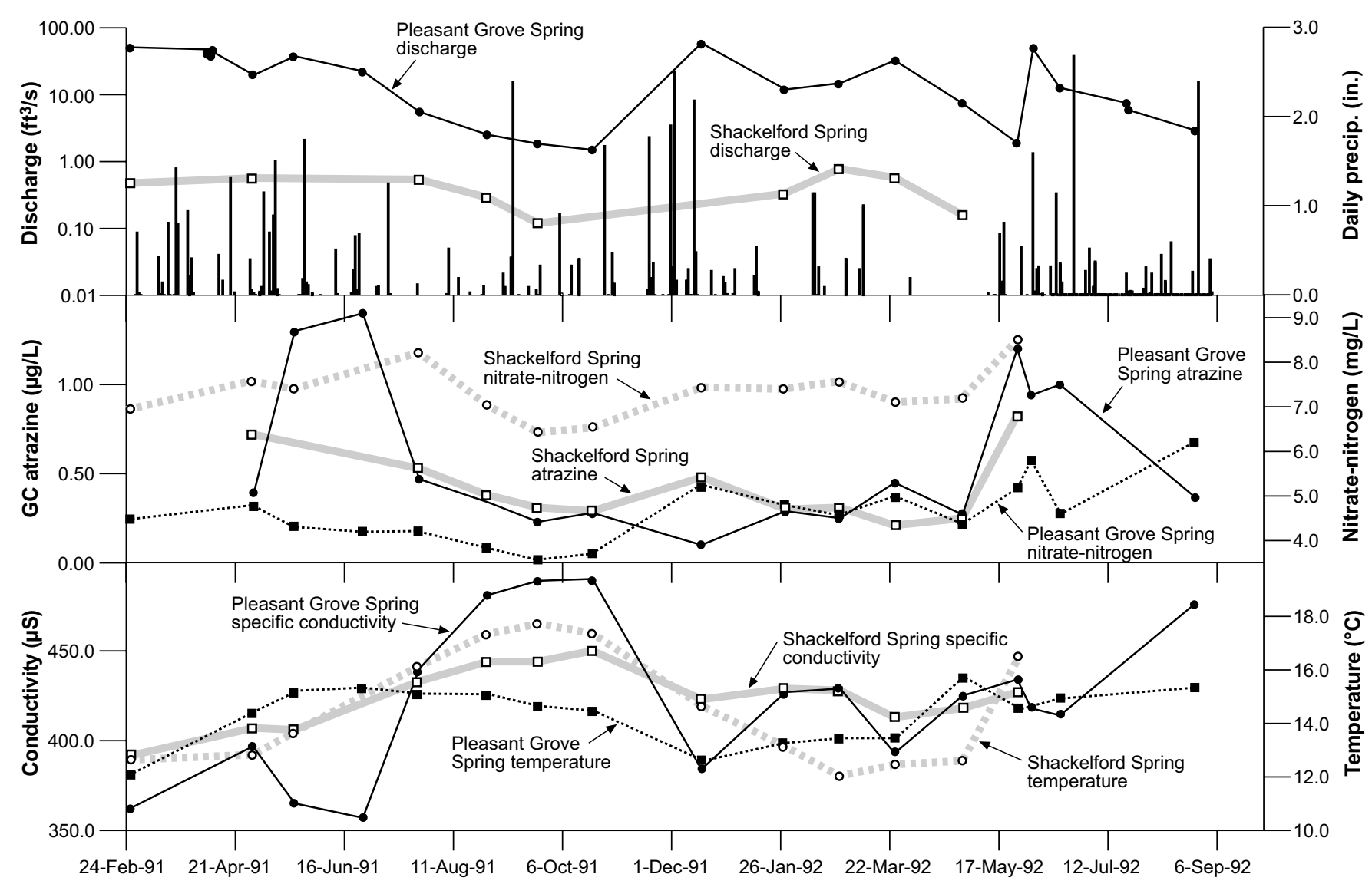

Figure 10. Discharge hydrograph and chemographs for Shackelford Spring during the time it was monitored, and comparative data for Pleasant Grove Spring. Shackelford Spring drains a headwaters area of the basin that is interpreted to have diffuse flow. 
$547 \mu \mathrm{S}$ as determined in the laboratory from samples. A Piper diagram of total analyses of major ions (Appendix $\mathrm{H}$ ) shows no major difference in water chemistry, however (Fig. 11), which supports the concept that the diffuse-flow area sustains base flow in the conduit-flow area.

There are some important differences between Pleasant Grove and Shackelford Springs. Shackelford Spring has significantly lower bacteria counts, possibly reflecting diffuse recharge. Average concentration of nitrate is significantly higher at Shackelford Spring, whereas triazines are higher at Pleasant Grove Spring. Both tri- azine and nitrate concentrations show less variability at Shackelford Spring than at Pleasant Grove Spring. Collectively, these characteristics support the diffuseflow conceptual model for the catchment area of Shackelford Spring in the headwaters area of the basin.

Pesticides. Pesticides have been found in basin ground water in detectable quantities by both GC and ELISA (Appendix I). For a list of pesticides used in Logan County and for which analyses were conducted, see Table 1. Atrazine (by GC) and triazines (by ELISA) are the most commonly detected pesticides, and are found

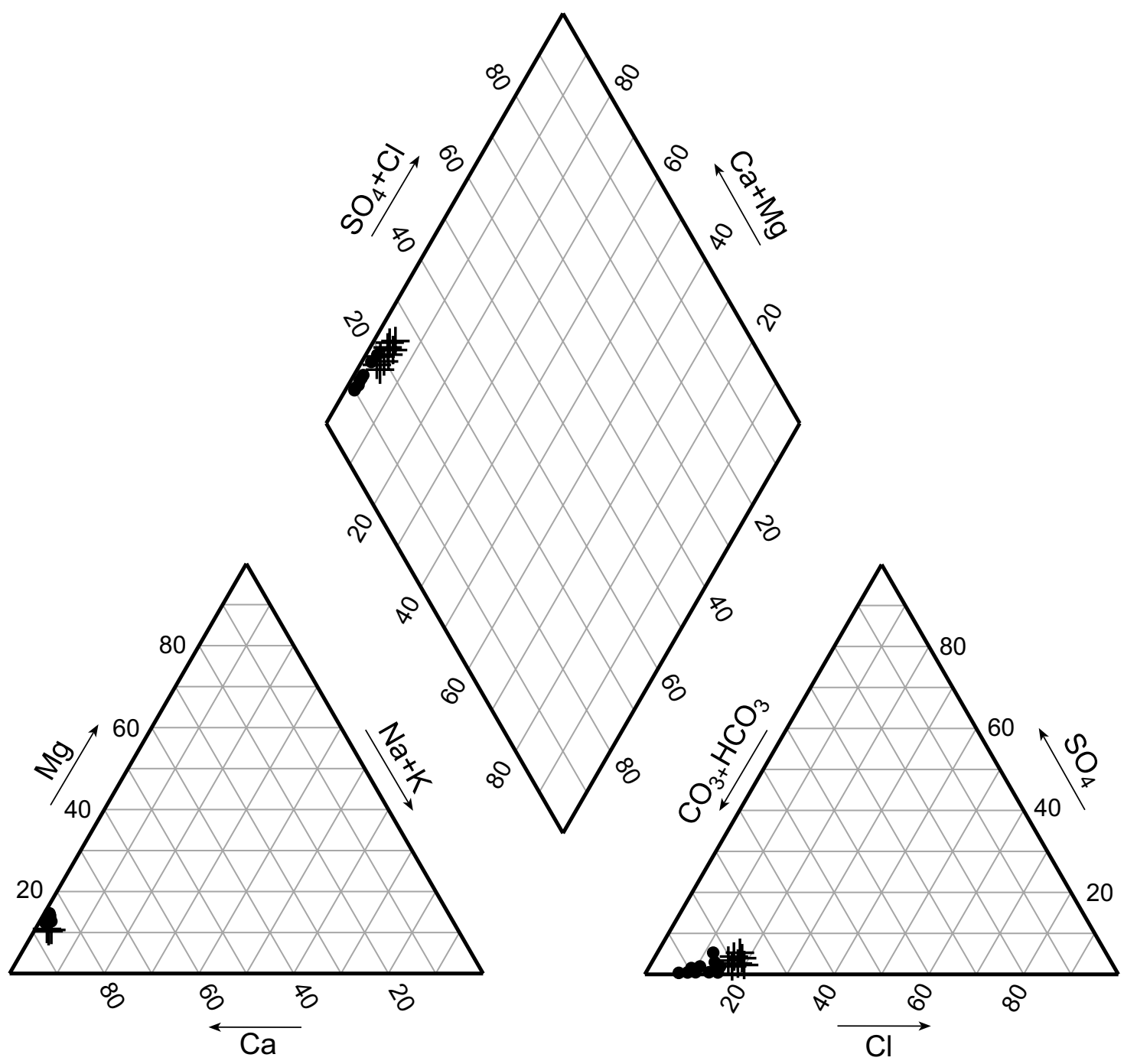

Percent of total milliequivalents per liter

EXPLANATION

- Pleasant Grove Spring ～+ Shackelford Spring

Figure 11. Piper diagram of major ionic constituents for Pleasant Grove and Shackelford Springs. All analyses are for total constituents. 
in the highest concentrations of any pesticides. Only triazines and alachlor have exceeded the EPA's maximum contaminant level (MCL). The highest concentration of pesticide detected $(44.0 \mu \mathrm{g} / \mathrm{L}$ of triazines at Pleasant Grove Spring on May 4, 1993) exceeded the MCL by an order of magnitude. A second sample collected the same day contained $28.0 \mu \mathrm{g} / \mathrm{L}$ of atrazine (determined by GC). These samples were collected during a major high-flow event following an extended dry period during planting season. During the early stages of the project, alachlor concentrations as determined by ELISA were considered only a presence-absence test, and therefore are not reported in Appendix I. The maximum alachlor concentration observed was determined by ELISA, however, and was $12.0 \mu \mathrm{g} / \mathrm{L}$. The sample was taken during the May 1993 high-flow event. Maximum concentrations of alachlor (GC determined), metolachlor (ELISA determined), and carbofuran (ELISA determined) detected were 6.1, 9.6, and 7.4 $\mu \mathrm{g} / \mathrm{L}$, respectively. Simazine was found only on rare occasions, but once at concentrations as high as $4.5 \mu \mathrm{g} / \mathrm{L}$. Other pesticides for which MCL's have not been determined (butylate, trifluralin, metribuzin, malathion, endosulfan I, and endosulfan II) have been detected, but at very low concentrations (less than $0.6 \mu \mathrm{g} / \mathrm{L})$. Some pesticides used in substantial quantities in the basin, such as 2,4-D, have short degradation half-lives (less than 30 days) in soil or water and have thus not been detected.

Several pesticides for which KGS does not have the ability to analyze are also used in large quantities in the basin. Four of these are important because of possible health issues and the quantity used in the area. Glyphosate, the fourth most commonly sold pesticide in Logan County, is an herbicide used on both corn and soybeans. Sales data for 1993 indicate over 40,000 lb (18 metric tons) were sold, but glyphosate has a small leaching potential. Three pesticides used in the county are among those considered a priority environmental or health concern by the EPA: betazon, disulfoton, and acifluorfen. Betazon and acifluorfen are herbicides used for soybeans and have moderate leaching potential. Disulfoton is an insecticide used for corn and has a small leaching potential. Sales in Logan County for all three were less than $8,300 \mathrm{lb}$ (3.7 metric tons), but disulfoton has an MCL of only $0.3 \mu \mathrm{g} / \mathrm{L}$. All three have a relatively short half-life, less than 30 days in soil. The importance of these pesticides as a ground-water contaminant in the Pleasant Grove Spring Basin is unknown.

The highest concentrations and most frequent pesticide detections occur from mid-March through June, after spring chemical application. Except for atrazine, concentrations above detection limit seldom occur during the fall and winter. Triazine concentrations decrease continuously during the fall and winter, reaching a mini- mum in February or early March. Figure 12 shows observations and triazine and nitrate analyses for Pleasant Grove Spring during phase I. The more widely spaced temperature and conductivity data shown on Figure 12 were collected before May 1992 and reflect discrete sampling prior to installation of monitoring equipment. Continuous monitoring began in May 1992 and produced the greater detail in the curves after that date. Precipitation data through December 1992 are daily totals from a volunteer station in Russellville, and may not reflect actual precipitation in the basin, particularly during summer months.

Nutrients. Nitrate-nitrogen is widespread and persistent in ground water in the basin. The average recommended application rate is $137 \mathrm{lb}$ of nitrogen per acre of crop land $(154 \mathrm{~kg} / \mathrm{hc})$ annually. Nitrate concentrations in ground water within the Pleasant Grove Spring Basin are typically low, however, only 3 to $5 \mathrm{mg} / \mathrm{L}$. Maximum concentration for the basin to date is $10.8 \mathrm{mg} / \mathrm{L}$ at the Upper Pleasant Grove Creek sampling point in December 1993 (Appendix G). Shackelford Spring had the highest average nitrate-nitrogen concentration from April 1992 to March 1993 during phase I $(7.39 \mathrm{mg} / \mathrm{L})$. The highest nitrate-nitrogen concentration recorded for Pleasant Grove Spring $(7.82 \mathrm{mg} / \mathrm{L})$ occurred in December 1993 at the recession of two closely spaced and significant rainfalls. The minimum value at Pleasant Grove Spring (2.37 mg/L) occurred April 11, 1994, during the largest discharge event gaged at the spring. The minimum value measured in the basin was the nitrate detection limit of $0.02 \mathrm{mg} / \mathrm{L}$ and was from the same sample as the highest ammonia concentration discussed below.

Nitrite, ammonia, and orthophosphate were also determined for monthly samples, but have not been determined in event samples because of logistical constraints caused by limited holding time. At Thad Flowers blue hole nitrite concentrations from samples collected from ponded water during a period of no flow (sample number TFBH0004) never exceeded $0.43 \mathrm{mg} / \mathrm{L}$. Ammonia never exceeded $4.46 \mathrm{mg} / \mathrm{L}$, and orthophosphate never exceeded $0.48 \mathrm{mg} / \mathrm{L}$; these were the highest ammonia and orthophosphate concentrations detected in the basin. Basinwide, nitrite averaged $0.04 \mathrm{mg} / \mathrm{L}$, ammonia $0.24 \mathrm{mg} / \mathrm{L}$, and orthophosphate $0.05 \mathrm{mg} / \mathrm{L}$ in 1990-91. The orthophosphate concentrations at Pleasant Grove Spring averaged $0.07 \mathrm{mg} / \mathrm{L}$. Boyer and Pasquarell (1994) found average nitrate-nitrogen concentrations of $0.1 \mathrm{mg} / \mathrm{L}$ in a forested karst ground-water basin, and $0.61 \mathrm{mg} / \mathrm{L}$ in another karst basin that is 80 percent forest. Concentrations of $0.007 \mathrm{mg} / \mathrm{L}$ of elemental phosphorus $(0.021 \mathrm{mg} / \mathrm{L}$ orthophosphate) are considered natural (Verduin, 1970); 


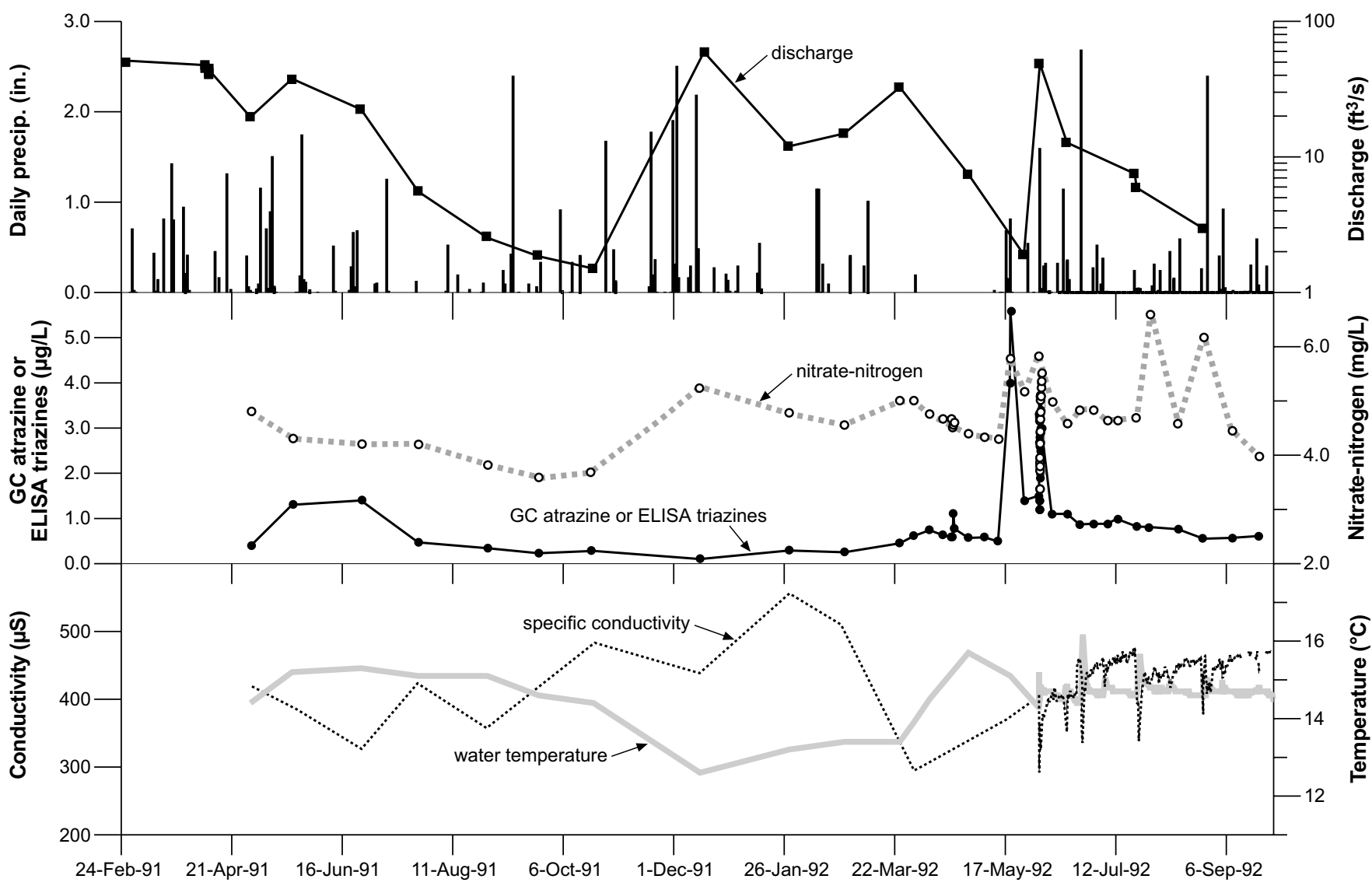

Figure 12. Discharge hydrograph, temperature, conductivity, nitrate-nitrogen concentration, and combined atrazine concentration before April 1992 (determined by GC) and triazine concentration after April 1992 (determined by ELISA) for the 1991-92 water year and the preceding 8 months at Pleasant Grove Spring.

higher concentrations may overstimulate the growth of aquatic plants.

Bacteria. Basinwide, bacteria counts always exceed the EPA's drinking-water standard of 1 colony-forming unit per $100 \mathrm{ml}(\mathrm{col} / 100 \mathrm{ml})$ and frequently exceed the standard for water-supply sources $(2,000 \mathrm{col} / 100 \mathrm{ml})$ by hundreds of colonies. Samples collected during phases I and II averaged $465 \mathrm{col} / 100 \mathrm{ml}$ of fecal coliform and 1,891 col/100 $\mathrm{ml}$ of fecal streptococci; maximum counts were 14,000 and $24,000 \mathrm{col} / 100 \mathrm{ml}$, respectively. High fecal coliform and fecal streptococci counts, and Salmonella counts ranging from 0 to $28,000 \mathrm{col} / 100 \mathrm{ml}$ were found at The Canyon karst window (Haszler, 1993). The magnitude of the Salmonella counts indicates fecal contamination. Ground-water dye tracing and water-quality data suggest that The Canyon karst window receives flow from both the vicinity of Oakville and areas with significant cattle concentrations.

Figures 13 and 14 show bacteria counts taken at Pleasant Grove Spring during phase I and phase II. Bacteria counts of samples collected at Pleasant Grove Spring prior to June 1992 averaged $617 \mathrm{col} / 100 \mathrm{ml}$ of fecal coliform and 3,444 col/100 $\mathrm{ml}$ of fecal streptococci (Appendix J). The highest counts occurred during the late summer and late winter during phase I. Bacteria counts between March 1994 and October 1994 averaged $425 \mathrm{col} / 100 \mathrm{ml}$ of fecal coliform and $889 \mathrm{col} / 100 \mathrm{ml}$ of fecal streptococci. Fecal coliform to fecal streptococci ratios for Pleasant Grove Spring suggest domestic sewage is the predominant source during flow recession, but animal waste prevails during the majority of the year. The highest counts determined during phase II occurred within a few days of major springtime highflow events. Generally, fecal streptococci were predominant in the first major high-flow event following an extended dry period, whereas fecal coliform were either simultaneously high or predominated during flow recession of the next high-flow event. The reduction in average fecal streptococci between the phase I and phase II sampling periods, from 3,444 to $889 \mathrm{col} / 100 \mathrm{ml}$, may be attributable to a facility to handle animal waste, built 


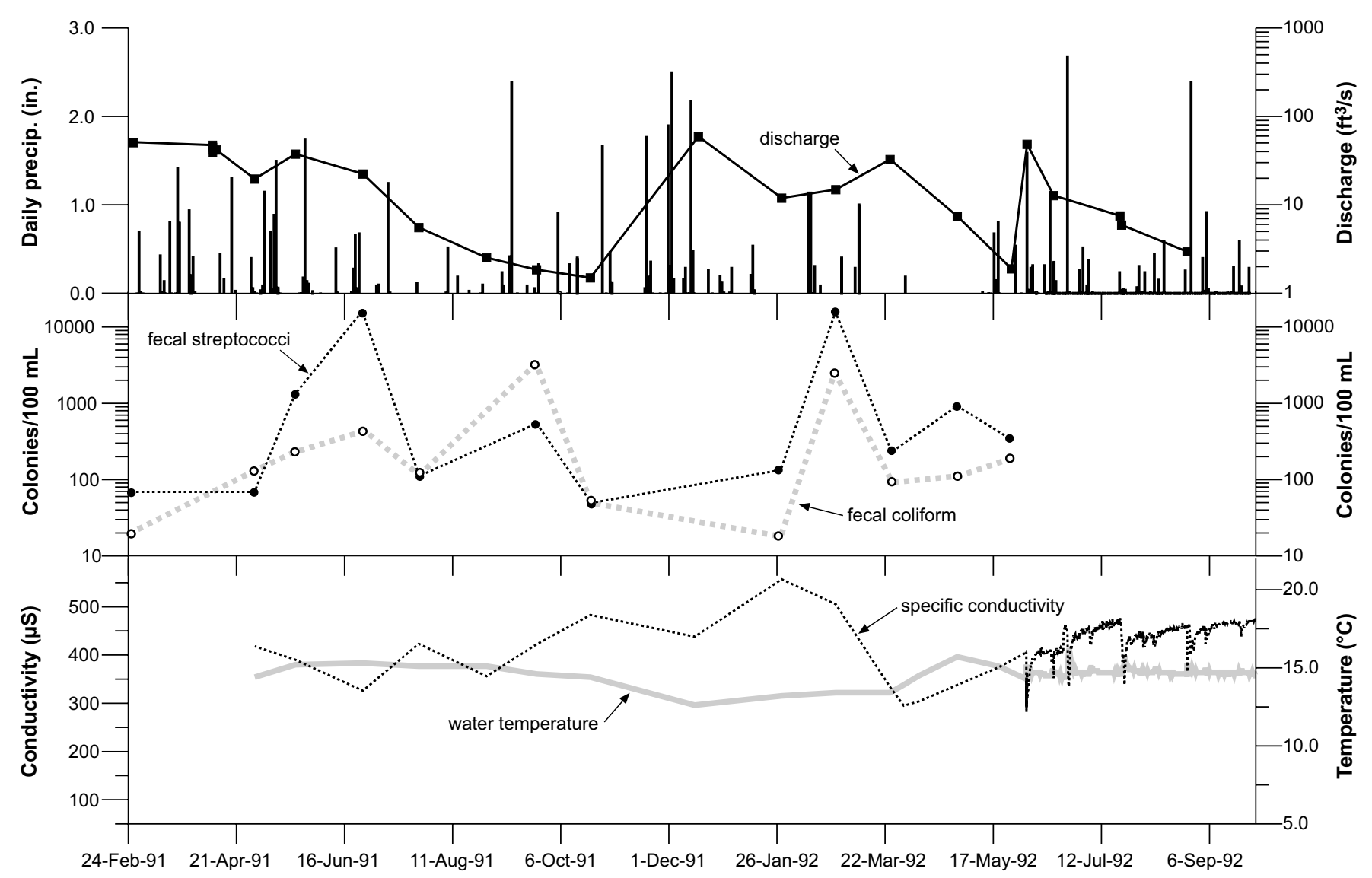

Figure 13. Line plot of phase I bacteria counts, temperature, conductivity, and discharge for Pleasant Grove Spring.

at a farm on Upper Pleasant Grove Creek between July 1992 and July 1993.

Speciated bacteria colonies were identified from samples collected in April and May of 1994 from Pleasant Grove Spring, The Canyon karst window, Joe Harper water well, and Leslie Page karst window in an attempt to clarify the origin of the streptococci (Enterococcus) bacteria. The associations were ambiguous for domestic animal or human sources, but came from warmblooded animals (Mark Coyne, UK College of Agriculture, written commun., September 16, 1994). No isolates were found for Streptococcus equinus or Streptococcus bovis, indicators of horses and cattle, perhaps because these bacteria species die rapidly. A small percentage of the enterococci present are associated with wildlife. The data suggested that the bacteria were not coming from soils or insects. Therefore, the highest Pleasant Grove Spring Basin counts are not of natural origin.

Optical Brighteners (Domestic Sewage). Optical brightening agents common in laundry detergent are frequently found in karst springs and indicate the presence of domestic sewage (Thrailkill and others, 1983;
Quinlan, 1987). To identify the source of high bacteria counts, cotton fabric dye detectors were exposed to flow from three springs in an attempt to measure the relative concentration of optical brighteners. Bacteria counts indicated that Leslie Page karst window was free of human or animal waste, whereas David Dotson Spring was polluted. Although all three deployment periods were during base flow, modest high-flow events (less than $10.0 \mathrm{ft}^{3} / \mathrm{s}\left[0.3 \mathrm{~m}^{3} / \mathrm{s}\right]$ maximum discharge at Pleasant Grove Spring) occurred during both of the 1994 deployments.

For all three deployments, no significant difference was found in the fluorescence of any of the exposed detectors and unexposed detectors prepared as controls (Joe Meiman, Mammoth Cave National Park, oral commun., 1994). The low-flow conditions prevailing during the detector deployment probably reduced the transport of brightener into ground water. Alhajjar (1990) found that optical brightening agents did not pass through septic-system drain fields in a glacial-drift setting. Bow-tie fabric dye detectors placed in David Dotson Spring during phase I were commonly positive for brightener, however, as determined by visual ex- 


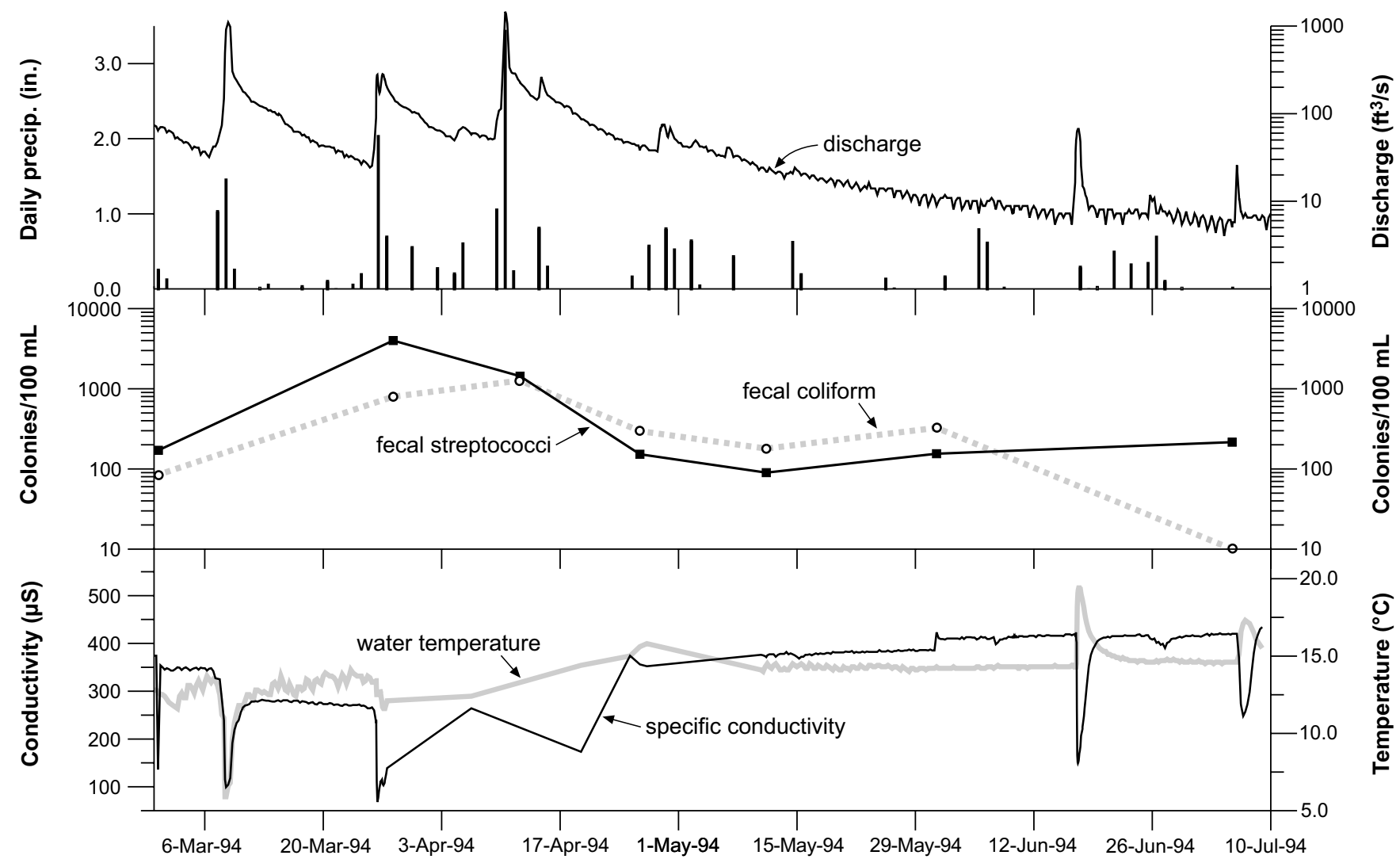

Figure 14. Line plot of phase II bacteria counts, temperature, conductivity, and discharge for Pleasant Grove Spring beginning in March 1994.

amination with an ultraviolet lamp. In addition, a fragment of steel wool, probably from a kitchen scrubbing pad, was discovered entangled on a dye-detector anchor in June 1991 at Pleasant Grove Spring.

Volatile Organic Compounds (Petroleum). Samples were also collected to measure volatile organic compounds on two occasions at Pleasant Grove Spring, Leslie Page karst window, and Billy Poore Spring, which is outside the drainage basin (Plate 1). Leslie Page karst window was thought to be pristine and Billy Poore Spring possibly polluted. Analyses were performed for 59 compounds, including vinyl chloride, benzene, carbon tetrachloride, styrene, toluene, xylene, and naphthalene. The samples were collected in 1993 during the May 4 high-flow event, and August 3, during base flow. Only 1,2,3 trichloropropane was above detection limits in any of the samples; it is an ingredient in the Styrofoam packing material used to ship the samples.

Effect on Drinking-Water Supplies. Because water from Pleasant Grove Spring is not used for human consumption, the chemical contaminants discharged from the spring might be assumed to be irrelevant for human health. The presence of constituents at the spring, however, may reflect the overall quality of the water in the aquifer. If so, private water supplies at other points might be affected. Although the systematic sampling of domestic ground-water supplies in the basin was not budgeted for, some samples were acquired in the course of the research. Samples were collected from three domestic wells in the area (identified as LDWW, MMWW, and MHWW in Appendix C). These wells contained up to $3.2 \mu \mathrm{g} / \mathrm{L}$ of triazines. Samples of treated and raw water were also collected in April 1994 from the Adairville water treatment plant (identified by the prefix CAWW in Appendix C), located $4 \mathrm{mi}(6.4 \mathrm{~km})$ south of Pleasant Grove Spring. Although the water plant withdraws its supply from the South Fork of Red River, and is not downstream of Pleasant Grove Spring, the flow in South Fork is maintained by other karst springs draining similar agricultural lands. Both samples of water contained more than $1.0 \mu \mathrm{g} / \mathrm{L}$ of triazines. These data suggest agricultural chemicals are having an impact on water used for human consumption in the region. 
Only one sample has been collected to date from Miller School House well. Although the well is poorly constructed and in the community of Oakville, the sample showed the well to be relatively free of agricultural chemicals, probably because of its location near the basin boundary. The sample was collected in April 1994 and was below detection level for all analyzed pesticides, by both ELISA and GC. Nitrate-nitrogen concentration was only $1.45 \mathrm{mg} / \mathrm{L}$.

Flow Regimes and Contaminants. The dual groundwater flow regimes in Pleasant Grove Spring drainage basin have significant implications for movement of contaminants in ground water. The diffuse-flow (slowflow) area, which is estimated to represent slightly less than half of the basin, drains into the conduit-flow-dominated area of the basin. Contaminants in the diffuseflow part of the aquifer seem to persist in the ground water for many months. However, because of the quick travel time in the fast-flow regime, contaminants carried into it during storms move rapidly through the system. Also, the residual contaminants stored in the smaller conduits and epikarst are diluted and flushed out. The conjunction of the plots of atrazine concentrations for Shackelford and Pleasant Grove Springs during base-flow conditions in the late summer of 1991 (Fig. 10) suggests that the slow-flow area acts as a reservoir for contaminants, which slowly trickle out into the fastflow part of the system, causing a background level of contamination to be maintained throughout the basin.

\section{Annual Mass Flux of Pesticides and Nitrate at Pleasant Grove Spring}

The results of the annual mass flux measurements for the 1992-93 and 1993-94 water years are shown in Figures 15 and 16, and mass totals are summarized in Table 3. These results reveal the potential for a wide range of concentrations and flow-weighted averages from year to year. An understanding of the causes of variation in the mass flux of nitrate and atrazine is essential to accurately assessing changes attributable to BMP installation.

Figures 15 and 16 show precipitation and discharge hydrographs, triazine and nitrate-nitrogen concentration, and atrazine-equivalent triazine and nitrate-nitrogen flux for the 1992-93 and 1993-94 water years at

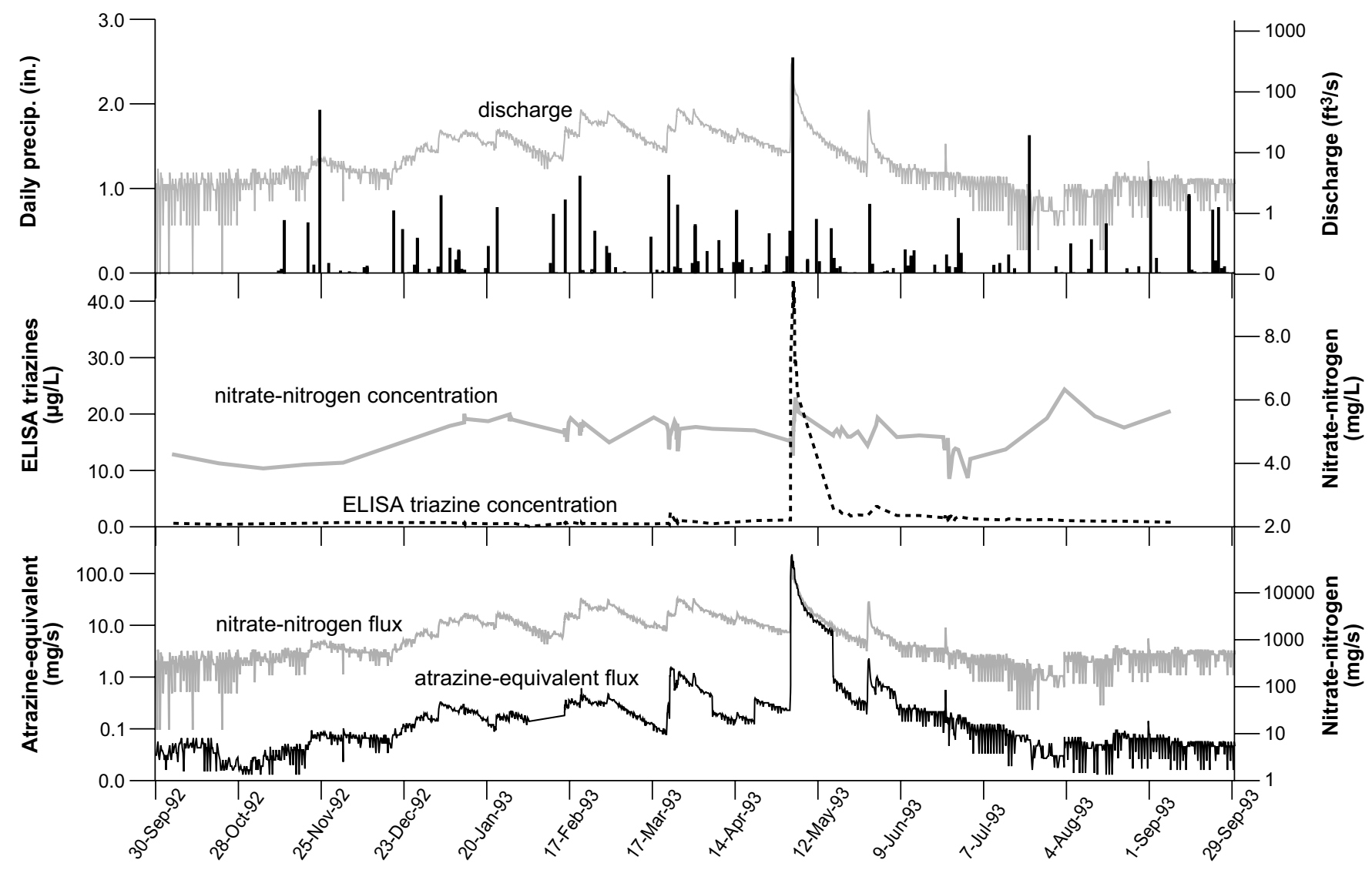

Figure 15. Plot of precipitation, discharge, nitrate-nitrogen concentration, nitrate-nitrogen flux, triazine concentration (determined by ELISA), and atrazine-equivalent triazine flux for Pleasant Grove Spring for the 1992-93 water year. 


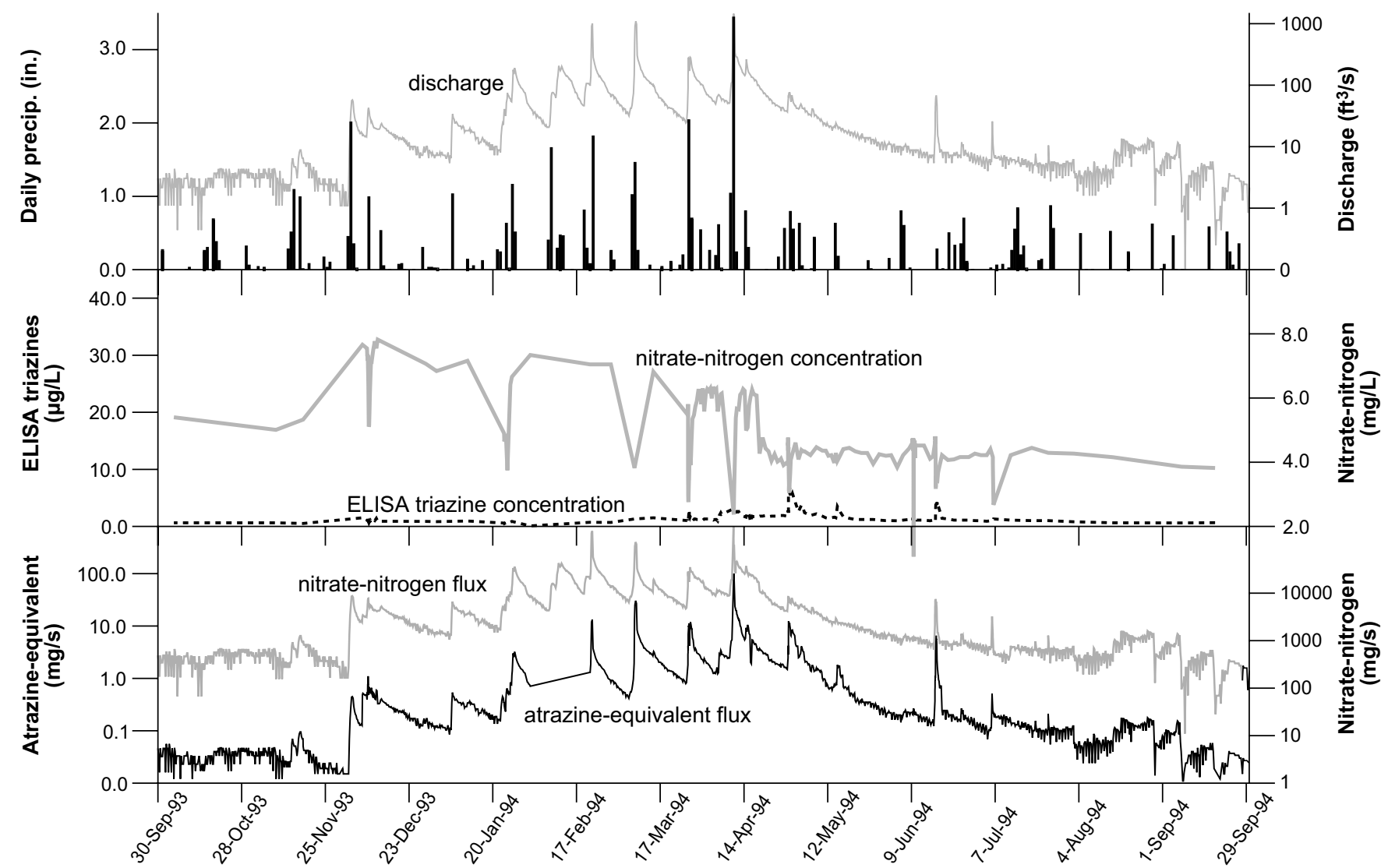

Figure 16. Plot of precipitation, discharge, nitrate-nitrogen concentration, nitrate-nitrogen flux, triazine concentration (determined by ELISA), and atrazine-equivalent triazine flux for Pleasant Grove Spring for the 1993-94 water year.

Pleasant Grove Spring. The general pattern of occurrence for triazines and nitrate from 1992 to 1994 is similar to the pattern from phase I monitoring (Fig. 12). In general, triazines are present in significant concentrations after springtime application, but also persist in detectable quantities well into the winter. Nitrate-nitrogen concentrations are greatest during base-flow conditions in the late fall and winter. Concentrations of atrazine-equivalent triazines exceeded the atrazine MCL only during three high-flow events in the spring of 1993 and four times during the spring of 1994, which emphasizes the importance of the relative timing of pesticide application and rainfall (Baker, 1980).

Total annual precipitation, discharge, mass flux of nitrate and atrazine-equivalent triazines, crop, and other relevant data are presented in Table 3 . The average discharge rate for water years 1992-93 and 1993-94 was $23.6 \mathrm{ft}^{3} / \mathrm{s}\left(0.7 \mathrm{~m}^{3} / \mathrm{s}\right)$. For the two years, the flowweighted averages of triazines at Pleasant Grove Spring, expressed as atrazine-equivalent, were $4.91 \mu \mathrm{g} / \mathrm{L}$ and

\begin{tabular}{|c|c|c|c|c|c|c|c|c|c|c|c|}
\hline \multirow[b]{2}{*}{ Water Year } & \multirow[b]{2}{*}{$\begin{array}{l}\text { Precipitation } \\
\quad \text { (in.) }\end{array}$} & \multirow[b]{2}{*}{$\begin{array}{c}\text { Discharge } \\
\left(\mathrm{ft}^{3}\right)\end{array}$} & \multirow[b]{2}{*}{$\begin{array}{c}\text { Percent } \\
\text { Runoff }\end{array}$} & \multicolumn{2}{|c|}{ Crop Acres } & \multicolumn{3}{|c|}{ Nitrate } & \multirow{2}{*}{\begin{tabular}{|c|} 
Triazine \\
\\
Average \\
Concentration \\
$(\mu g / L)$
\end{tabular}} & \multicolumn{2}{|c|}{ Atrazine-Equivalent } \\
\hline & & & & Corn & $\begin{array}{l}\text { Total } \\
\text { Row }\end{array}$ & $\begin{array}{c}\text { Average } \\
\text { Concentration } \\
(m g / L)\end{array}$ & $\begin{array}{c}\text { Mass Flux } \\
(\mathrm{kg})\end{array}$ & $\begin{array}{c}\text { Flow- } \\
\text { Weighted } \\
\text { Average } \\
\text { (mg/L) }\end{array}$ & & $\begin{array}{c}\text { Mass Flux } \\
(\mathrm{kg})\end{array}$ & $\begin{array}{c}\text { Flow- } \\
\text { Weighted } \\
\text { Average } \\
(\mu g / L)\end{array}$ \\
\hline $1991-92^{1}$ & $>39.52^{2}$ & NA & $\mathrm{NA}$ & 3,042 & 7,154 & 4.2 & NA & NA & 1.64 & NA & NA \\
\hline 1992-93 & 34.58 & $3.6 \times 10^{8}$ & 28.7 & 2,925 & 7,164 & 4.98 & 51,105 & 5.0 & 4.84 & 50.16 & 4.91 \\
\hline \begin{tabular}{|l|}
$1993-94$ \\
\end{tabular} & 52.2 & $11.3 \times 10^{8}$ & 59.4 & 3,473 & 7,201 & 4.86 & 183,643 & 5.7 & 1.84 & 30.75 & 0.97 \\
\hline
\end{tabular}


$0.97 \mu \mathrm{g} / \mathrm{L}$, respectively. For nitrate-nitrogen, flowweighted average concentrations were less variable: $5.0 \mathrm{mg} / \mathrm{L}$ for $1992-93$ and $5.7 \mathrm{mg} / \mathrm{L}$ for 1993-94. Approximately 11.5 percent of applied nitrogen fertilizer $(15.86 \mathrm{lb} /$ acre of row crop [17.79 kg/hc]) was discharged at Pleasant Grove Spring during 1992-93, whereas only $0.033 \mathrm{lb} /$ acre $(0.037 \mathrm{~kg} / \mathrm{hc})$ of atrazine-equivalent triazines per acre of corn, or 1.65 percent of the estimated atrazine applied, was discharged. Total nitrate-nitrogen mass flux was significantly higher in 1993-94 than in 1992-93 and significantly lower for atrazine-equivalent in 1993-94 than in 1992-93 (Table 3). The nitrate-nitrogen flux for all years represents the minimum nitrogen flux, because nitrite, ammonia, and organic nitrogen were not determined for samples collected during storms or routine base flow beyond phase I. The atrazine-equivalent flux for 1993-94 represents 1.0 percent of the estimated atrazine applied, whereas the nitrate flux represents an astounding $64.7 \mathrm{lb} / \mathrm{acre}(72.5 \mathrm{~kg} / \mathrm{hc})$ or 47.2 percent of the estimated $137 \mathrm{lb} /$ acre $(154 \mathrm{~kg} / \mathrm{hc})$ of applied nitrate-nitrogen. Precipitation in 1992-93 was 34.6 in. $(88 \mathrm{~cm})$, but in $1992-93$ increased to $52.2 \mathrm{in}$. $(209 \mathrm{~cm})$.

The annual flux of metolachlor and carbofuran at Pleasant Grove Spring must be considered a gross estimate because the correlation between ELISA- and GCdetermined metolachlor concentration was not as strong as for triazines, and no GC method for detecting carbofuran was available at KGS. In 1992-93 the annual metolachlor discharge at Pleasant Grove Spring was $15 \mathrm{lb}$ $(6.8 \mathrm{~kg})$, and carbofuran was $1 \mathrm{lb}(0.5 \mathrm{~kg})$. In 1993-94 the annual mass discharged was $2 \mathrm{lb}(0.9 \mathrm{~kg})$ for metolachlor and $7 \mathrm{lb}(3.2 \mathrm{~kg})$ for carbofuran. The decrease in metolachlor may be the result of weather conditions, but the increase in carbofuran is unexplained.

The striking contrast in triazine concentration and flux in May 1993 and May 1994 is not yet understood. For both years, annual mass-flux totals were substantially less for alachlor, carbofuran, and metolachlor than for atrazine-equivalent triazines. Also, the mass flux of nitrate was substantially greater in 1993-94 than in the previous year. Three possible causes for the change in triazine flux are reduced use, shifts in crop patterns, and enhanced degradation caused by weather conditions. Enhanced degradation of atrazine and increased leaching of nitrate in wet years have been noted by several authors (Johnston and others, 1967; Baker and others, 1978; Dao and others, 1979; Baker, 1980). The relatively wet spring of 1993-94 may have resulted in both greater degradation of atrazine, and more numerous but less intense runoff events during the 1993-94 application season than in 1992-93.

The distribution of crops within the basin may affect the efficiency of triazine-laden runoff in reaching streams and eventually ground water. Although crop maps have been prepared, the areal distribution of the crops from year to year has not been studied thus far. Corn tends to dominate the headwaters area of Upper Pleasant Grove Creek during some years, however. Upper Pleasant Grove Creek receives surface runoff from immediately adjacent fields and discharges flow into the ground at George Delaney swallow hole and other points. This may provide a direct route for triazine transport into ground water during the years corn is concentrated along Upper Pleasant Grove Creek.

Another possible explanation of a change in pesticide flux is a change in total herbicide use by farmers. An annual census of actual chemical applications was beyond the scope of this research, but sales data for pesticides can provide a sense of overall trends in chemical use. A total of 90,082 lb of atrazine was sold in Logan County in 1992, whereas 67,789 lb was sold in 1993 (Ernest Collins, Kentucky Division of Pesticides, oral commun., 1994), a 25 percent reduction. Corn production was only 80 acres (32 hc) greater during 1993-94, however-an insignificant increase. Carbofuran sold in Logan County decreased from 9,323 lb (4,229 kg) in 1992 to $6,194 \mathrm{lb}(2,810 \mathrm{~kg})$ in 1993 , and metolachlor increased from $35,112 \mathrm{lb}(15,927 \mathrm{~kg})$ in 1992 to $44,374 \mathrm{lb}(20,128 \mathrm{~kg})$ in 1993. At a meeting with farmers in the study area in February 1993, the project was explained and they were asked if they would support changes in BMP's. At this meeting, preliminary data on the 1992-93 atrazine concentrations were released, possibly influencing farmers to use less atrazine. Pleasant Grove Spring Basin is only 3 percent of the area of Logan County, however-hardly sufficient to account for a 25 percent reduction in sales throughout the county. Statewide, atrazine sales increased modestly from 1992 to 1993 . Also, there is no demonstrable link between general sales data and pesticide use within the basin.

A complete nitrogen budget for the basin was beyond the resources of this research, but some generalizations can be made. There is no domestic waste-water collection system in the basin, and all sewage is disposed of privately. Assuming each resident adds $5.15 \mathrm{lb}(2.34 \mathrm{~kg})$ of nitrogen to the ground water per year (Canter and Knox, 1985), only about a ton per year $(912 \mathrm{~kg} / \mathrm{yr})$ would be added by the estimated 390 residents in the basin, a comparatively small amount. Likewise, net deposition for all livestock would be nearly zero because most forage and feed grain is grown in the basin. Nitrogen gain from atmospheric deposition may be significant, however. Precipitation samples collected in 1993-94 at Pleasant Grove Spring had a depth-weighted average concentration of $0.31 \mathrm{mg} / \mathrm{L}$ of nitrate-nitrogen, suggesting that $3.0 \mathrm{lb}$ per acre $(3.5 \mathrm{~kg} / \mathrm{hc})$ of nitrate-nitrogen is deposited annually by precipitation alone. A total at- 
mospheric deposition rate of $5 \mathrm{lb}$ per year per acre $(5.7 \mathrm{~kg} / \mathrm{yr} / \mathrm{hc})$ is commonly assumed for Kentucky (Gary Felton, UK College of Agriculture, oral commun., 1995). At this rate, $50,270 \mathrm{lb}(22,802 \mathrm{~kg})$ of nitrogen is deposited by precipitation in the basin per year, equivalent to half of the 1992-93 nitrate-nitrogen flux from Pleasant Grove Spring! Even if all of the atmospheric nitrogen deposited in the basin is discharged as nitrate from Pleasant Grove Spring, however, the remaining nitrate flux would still represent 6.3 percent of the nitrogen applied as fertilizer in the basin.

The amount of nitrogen removed from the basin is thought to be small except for the nitrogen exported by harvesting and discharged from Pleasant Grove Spring. Because ammonia and nitrite were only found in small concentrations during phase I, and water discharging from Pleasant Grove Spring is well oxygenated, denitrification in ground water is thought to be minor. The significance of denitrification at feed lots and manure lagoons is unknown, but there are few of these facilities in the basin. Approximately 7,000 acres $(2,833 \mathrm{hc})$ of the basin is in row crop production. Of this, typically 3,000 acres $(1,214 \mathrm{hc})$ is in soybeans, which obtain most of their nitrogen from the soil, although they also fix nitrogen from the atmosphere. The annual nitrogen loss from the watershed via harvesting is unknown, but it is likely much larger than the combined nitrogen gains outlined above because of the large acreage of row crops harvested.

In summary, the cause of variability in pesticide flux has not been identified. Possible causes include weather conditions, changes in the amounts and types applied, and cropping patterns. Nitrate-nitrogen flux is more constant. With the exception of atmospheric deposition and fertilizer, the amount of nitrogen added to the basin is small, and with the exception of harvest and nitrate-nitrogen discharged at Pleasant Grove Spring, nitrogen losses from the basin are probably small. Since crop uptake exceeds atmospheric deposition, the result is a net loss from the watershed, which must be replaced by fertilizers. At an average application rate of $137 \mathrm{lb} /$ acre $(154 \mathrm{~kg} / \mathrm{hc})$, approximately 440 tons $(400,000 \mathrm{~kg})$ of nitrogen is applied to corn, wheat, and tobacco each year. Although the specific source of the nitrate-nitrogen discharged from Pleasant Grove Spring has not been demonstrated and the nitrate-nitrogen flux cannot be entirely attributed to nitrogen applied to crops, fertilizer remains the most probable source of nitrate-nitrogen in ground water.

Annual Flux at Upstream Sites. Stage records and flow data at Upper Pleasant Grove Creek and George Delaney swallow hole were not satisfactory for the estimation of mass flux. Flux was estimated for Leslie Page karst window, but both flow monitoring and sampling were not as complete as the initial site assessment suggested was possible. Nevertheless, estimates were calculated for Leslie Page karst window for 1993-94 (Fig. 17). The nitrate-nitrogen flux was 4.9 short tons ( 4.5 metric tons) or a flow-weighted average of $7.04 \mathrm{mg} / \mathrm{L}$. Pesticide flux for atrazine-equivalent triazines was $1.83 \mathrm{lb}$ $(0.83 \mathrm{~kg})$ or $1.3 \mu \mathrm{g} / \mathrm{L}$ flow-weighted average; metolachlor was $0.04 \mathrm{lb}(0.02 \mathrm{~kg})$ or $0.04 \mu \mathrm{g} / \mathrm{L}$ flow-weighted average. The carbofuran flux was nearly zero. Although the catchment of Leslie Page karst window has not been mapped, average discharge indicates it is relatively small. Also, the fields immediately surrounding the site were mostly wheat and soybeans in 1993-94, which reduced the quantity of atrazine used in the vicinity that year.

High-Flow Events at Pleasant Grove Spring. Numerous authors have demonstrated the critical importance of sampling karst springs at closely spaced intervals during high-flow events to quantify natural constituents and detect pollutants (Ashton, 1966; Quinlan and Alexander, 1987; Ogden, 1988). An attempt was made to sample every high-flow event during the planting season. The event samples were supplemented and bracketed by manually collected base-flow samples. Some high-flow events were supplemented with manual samples. In addition, several fall and winter high-flow events were sampled during the 1992-93 water year. A common feature of many of the resulting graphs is that whereas major runoff events resulted in lowered nitratenitrogen concentrations, triazine concentrations generally increased. Increased mass flux of both atrazine-equivalent triazines and nitrate-nitrogen is caused by the large increase in discharge. Concentrations of pesticides at Pleasant Grove Spring are commonly two orders of magnitude greater during springtime, high-flow events than during winter events. Also, most chemographs for storms during planting season show a positive relationship between total suspended solids and triazines during peak discharge. Cross-plots of total suspended solids versus triazines show no correlation, however, and there is no apparent difference in atrazine concentrations in filtered and unfiltered water samples from Pleasant Grove Spring. The apparent relationship between triazines and sediment for many Pleasant Grove Spring chemographs is caused by both constituents being common to runoff, rather than the sorption of atrazine on filterable sediment. The travel time for pesticides in runoff from the headwaters of the basin to Pleasant Grove Spring is less than a day.

An excellent example of increased triazine concentration and decreased nitrate-nitrogen concentration during high flow is the June 1992 event (Fig. 18). Approximately 1.6 in. $(4 \mathrm{~cm})$ of rain was recorded at the 


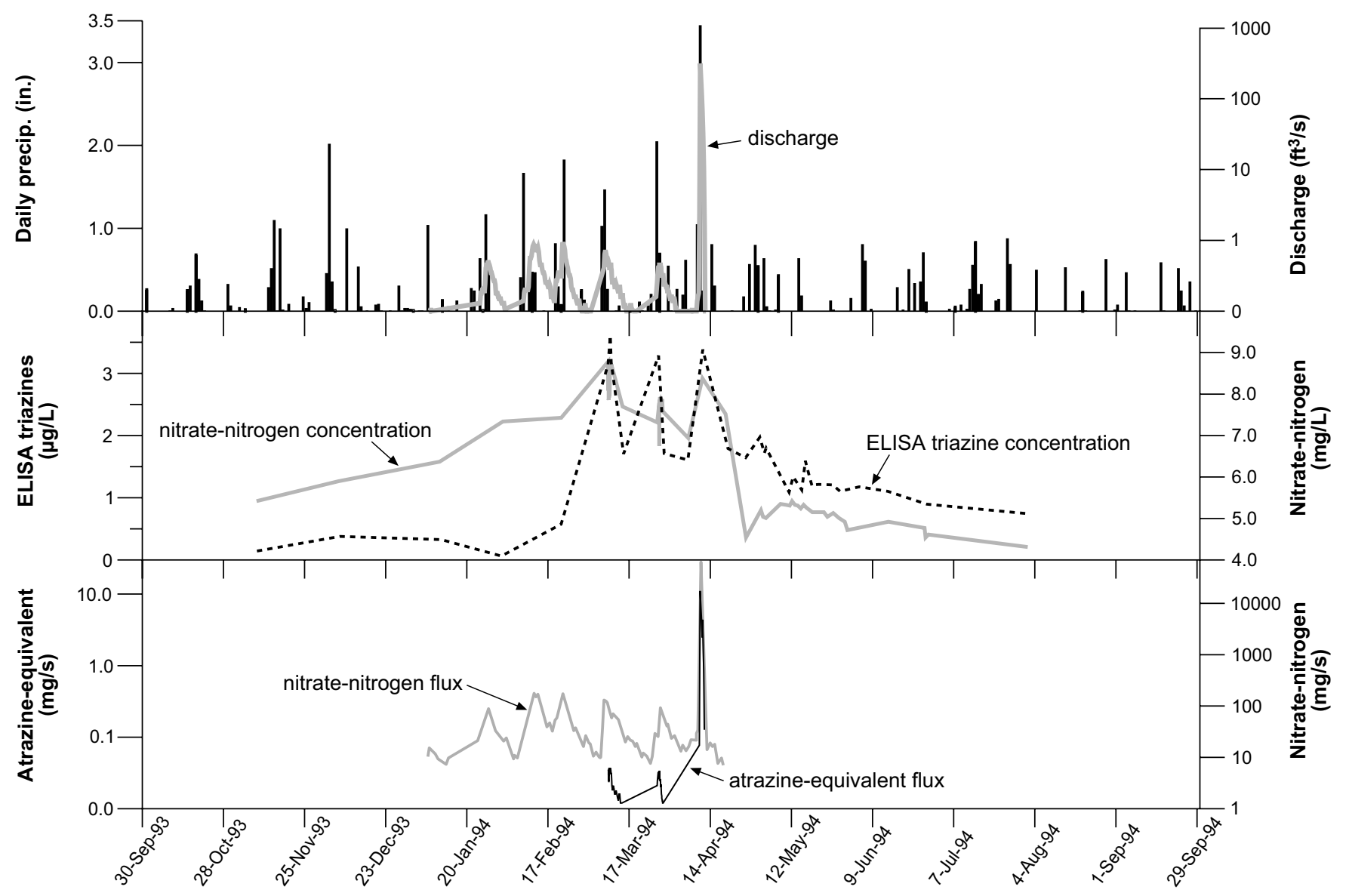

Figure 17. Plot of precipitation, discharge, nitrate-nitrogen concentration, nitrate-nitrogen flux, triazine concentration (determined by ELISA), and atrazine-equivalent triazine flux for Leslie Page karst window for the 1993-94 water year.

Russellville volunteer station between 19:00 on June 3 and 19:00 on June 4 . Following the first rise in discharge, a small decrease in triazine concentration occurred, followed by a series of sharp rises in concentration that corresponded to dramatic increases in suspended sediment. The peaks in sediment also corresponded to decreases in nitrate concentration. During the recession, suspended sediment decreased significantly, nitratenitrogen increased to pre-event levels, and triazine steadily increased, then dropped off toward pre-event concentrations. The relationship between sediment, nitrate-nitrogen, and triazines indicates that runoff diluted the nitrate, while carrying significant concentrations of triazines.

Data from two storms in February 1993 show somewhat different results (Fig. 19). The February 15 storm accumulated 0.87 in. $(2.2 \mathrm{~cm})$ of rain over 17 hours at the Pleasant Grove Spring gage. Daytime temperatures were above $40^{\circ} \mathrm{F}\left(4.4^{\circ} \mathrm{C}\right)$, but dipped below freezing on the morning of February 17. The discharge hydrograph and chemographs show only moderate increases in dis- charge and turbidity, whereas specific conductivity, triazine content, and nitrate-nitrogen content decreased. The February 21 storm was more intense, resulting in 1.12 in. $(2.84 \mathrm{~cm})$ of rain accumulating in only 5 hours. Temperatures were above freezing. While specific conductivity went down, stage and turbidity increased significantly. Triazine concentration increased slightly, but overall both triazines and nitrate-nitrogen changed little in concentration. Discharge and turbidity increased dramatically in the case of the February 21 storm, although cover on the fields was largely unchanged between storms. Comparison of the two February storms revealed that although the triazine concentrations continued to be much lower than those measured during the planting season, the remaining triazines, nitrate, and significant sediment loss are mobilized more by storms that are relatively intense.

In May 1993 the greatest concentration of triazines and GC-determined atrazine for Pleasant Grove Spring occurred during a high-flow event beginning in the evening of May 3 and lasting through May 4 (Fig. 20). 


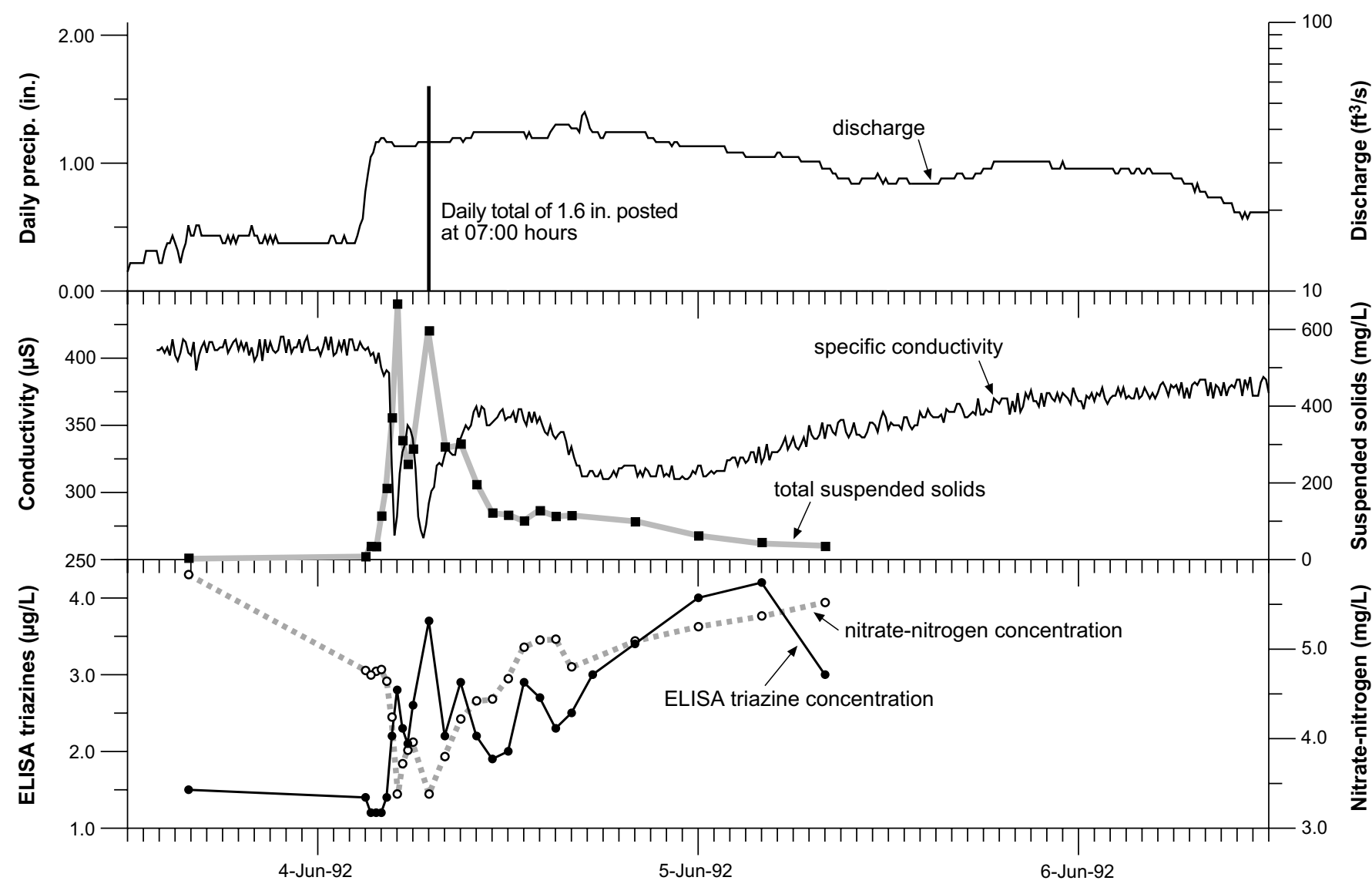

Figure 18. Discharge hydrograph and chemographs for the June 1992 high-flow event at Pleasant Grove Spring. Note the opposite deflection of the nitrate and triazine concentrations.

Approximately 3.04 in. $(7.72 \mathrm{~cm})$ of rain fell during the afternoon and evening of May 3. Data recorded during the event are less than ideal because the water-quality logger probes were fouled and the intake lines of the Isco samplers were crimped by the high flow velocities. No samples were collected during peak flow. The highest concentration of pesticide detected was $44.0 \mu \mathrm{g} / \mathrm{L}$ of triazines, in a sample collected during the early recession limb of the hydrograph. A sample collected manually the same day contained $28.0 \mu \mathrm{g} / \mathrm{L}$ of atrazine (GC-determined). Maximum triazine concentrations were probably greater than those measured. The event contributed at least $44.5 \mathrm{~kg}$ of atrazine-equivalent triazines, 88.7 percent of the 1993 annual mass flux. In addition, sediment transport during this storm was significant. Total suspended sediment concentrations reached a maximum of $202 \mathrm{mg} / \mathrm{L}$, and turbidity values exceeded 1,000 nephelometric turbidity units (NTU's), the maximum range of the turbidity probe. Sediment was deposited to depths of 2 in. $(5 \mathrm{~cm})$ in the channel and on the banks of Pleasant Grove Creek for hundreds of feet downstream of the spring. At the time of the storm, a large number of fields had been simultaneously tilled, and crops had not yet emerged. A biological inventory conducted downstream of the spring in 1994 by the Kentucky Division of Water revealed that Pleasant Grove Creek was biologically impaired, probably by sediment (Sampson, 1995).

During the high-flow event on December 10, 1993, triazines were detected at Pleasant Grove Spring in concentrations as high as $1.5 \mu \mathrm{g} / \mathrm{L}$, even though this was 8 months after the application season. No analyses are available for the storm on December 4, but wetting of the soil after a very dry fall (Fig. 21) may have mobilized triazines stored in the soil and diffuse-flow zone. The December 10 rainfall then would have flushed triazines into the conduit system. The concentration of triazines at Pleasant Grove Spring fell, however, as runoff flowing directly into swallow holes diluted the relatively limited mass of triazines and nitrate-nitrogen stored in the aquifer. The presence of triazines in these concentrations strongly suggests that some agricultural chemicals are being stored in ground water or soil long enough 


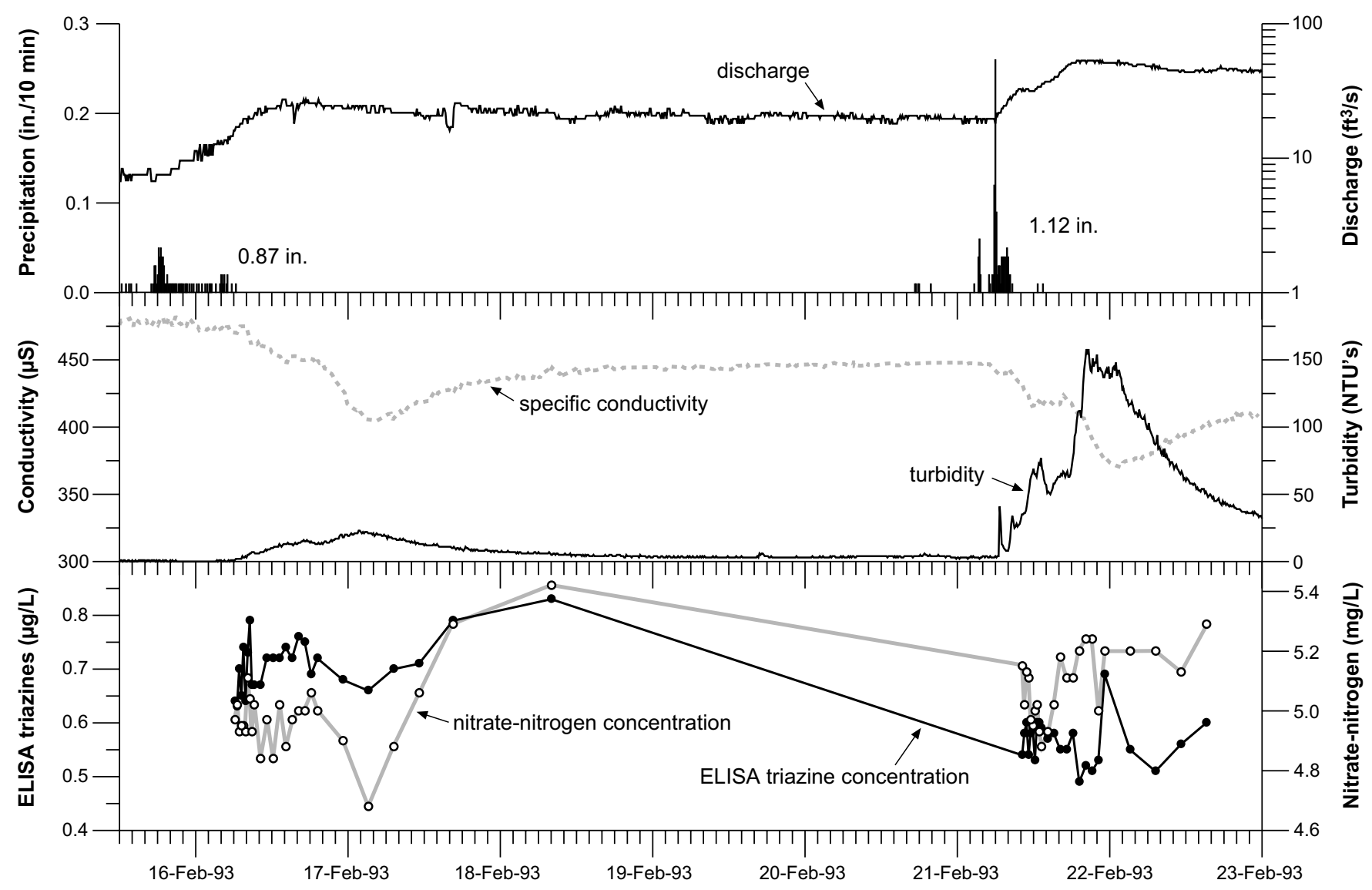

Figure 19. Discharge hydrograph and chemographs for February 1993 high-flow events at Pleasant Grove Spring showing variable response to late-winter storms of different intensity.

to expose those who drink the ground water to these compounds. This risk occurs nearly year-round.

The timing of the arrival of runoff from the headwaters of the basin at Pleasant Grove Spring is important to understanding the origin of contaminants. Only one quantitative ground-water dye trace was completed in time for this report, but water-quality records of storms have provided insight into travel times from George Delaney swallow hole, the principal insurgence during most events. A storm producing 1.04 in. $(2.64 \mathrm{~cm})$ of rain began at 22:40 on January 6, 1994, reached its maximum intensity at midnight, and ended by 04:00 on January 7 (Fig. 22). This storm broke a relatively dry 4-week-long period with total precipitation of only 2.3 in. $(5.8 \mathrm{~cm})$. Air temperature steadily fell during the early morning of January 7, and was below freezing by 09:50. The stage at the George Delaney swallow hole recorder began to rise at midnight and peaked at 07:50 on January 7 (Fig. 22). Discharge at Pleasant Grove Spring began to increase at 00:50 on January 7 and peaked at 12:10. Velocity increased synchronously with discharge. Conductivity and water temperature remained constant until 10:00, however, when small declines in both were measured, followed by rapid declines beginning at 13:00; minimum values were reached at 17:10 and 19:00, respectively. Turbidity rose rapidly at $06: 00$, declined to pre-event readings, then began rising again at 09:00, peaking at 15:20. The early peak in turbidity is interpreted as the arrival of runoff from fields surrounding Pleasant Grove Spring in the immediate catchment area of the rise pool. The second peak in turbidity at 15:20 and the minimum conductivity at 17:10 are interpreted as the arrival of inflow from George Delaney swallow hole. The delayed temperature minimum was caused by warming of the runoff by the thermal mass of the bedrock. Under these flow conditions, the expected travel time to Pleasant Grove Spring after a storm peak is 15 hours from George Delaney swallow hole. Average straight-line velocity from George Delaney swallow hole is $0.20 \mathrm{ft} / \mathrm{s}$, whereas velocity along the hypothesized flow route is $0.26 \mathrm{ft} / \mathrm{s}$; both values are in general accordance with dye traces and the monitored apparent velocity. 


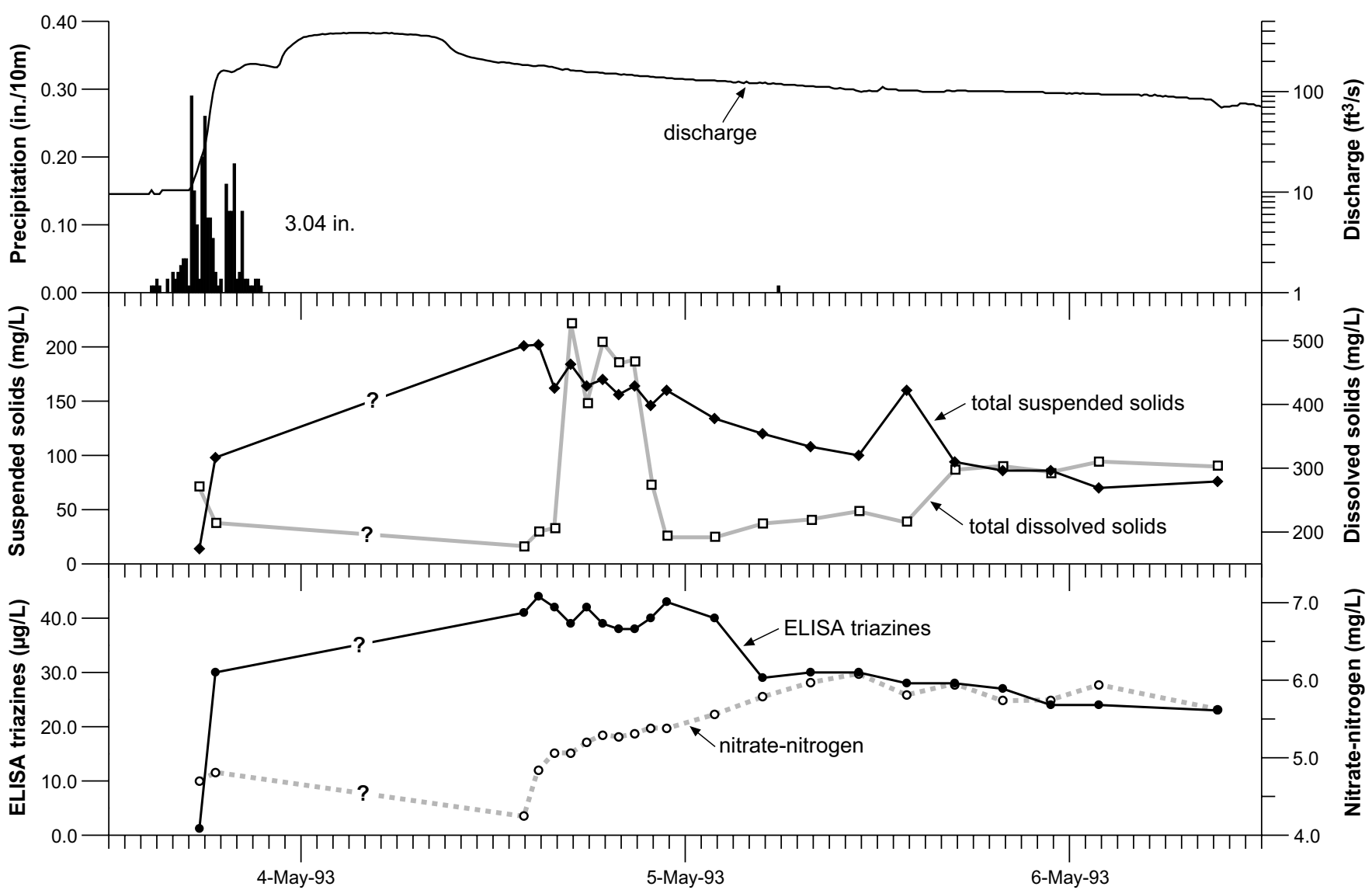

Figure 20. Chemographs and discharge hydrograph for the May 1993 high-flow event at Pleasant Grove Spring, illustrating highest triazine concentrations determined to date.

Although a sediment mass flux was not estimated because of the poor record from the turbidity probe caused by bacteria fouling, the probe generally performs well during the winter when biological growth rates are slow. High-flow events in late January 1994 revealed an apparent contradiction between periods of turbidity and high flow velocities from the spring mouth (Fig. 23). Air temperatures during all three storms in January 1994 were above freezing. Both turbidity and velocity values would be expected to be simultaneously higher if the faster flowing water were consistently entraining sediment from the conduits. On January 25 and 26 , however, turbidity exceeded $100 \mathrm{NTU}$, then returned to pre-event levels of approximately 25 NTU, while velocity rose to nearly $1 \mathrm{ft} / \mathrm{s}$. An event on January 27 raised both turbidity and velocity, as expected. Another period of rain early on January 28 again elevated velocity, but only briefly elevated turbidity, which quickly returned to pre-event levels. As in the case of the January 7 storm, conductivity and water temperature indicate that the turbidity is associated with runoff rather than mobilized sediment that has been stored in the conduits.
The discordance of turbidity and velocity during the late January storms indicates that ground conditions during the storm, such as type of cover crops, amount of crop residue, depletion of loose particles by earlier storms, cohesion from wetting, and frozen ground, have a major influence on sediment loss.

Like the May 1993 event, the storm of March 27, 1994 (2.68 in. [6.8 cm] between 18:50 March 26 and 12:00 March 29), also transported significant volumes of sediment (Fig. 24). The discharge hydrograph, total suspended solids, total dissolved solids, total nitrate-nitrogen, and triazines are presented in Figure 24 . This event is notable because, unlike the May event, the triazine concentrations did not synchronously rise with total suspended solids. The lack of a relationship (such as illustrated in Figure 25) is probably because the storm occurred early in the application season, when only some of the fields had had chemicals applied to them.

Figure 25 also illustrates the maximum total suspended sediment concentration sampled from Pleasant Grove Spring to date, $2,278 \mathrm{mg} / \mathrm{L}$. This sample was col- 


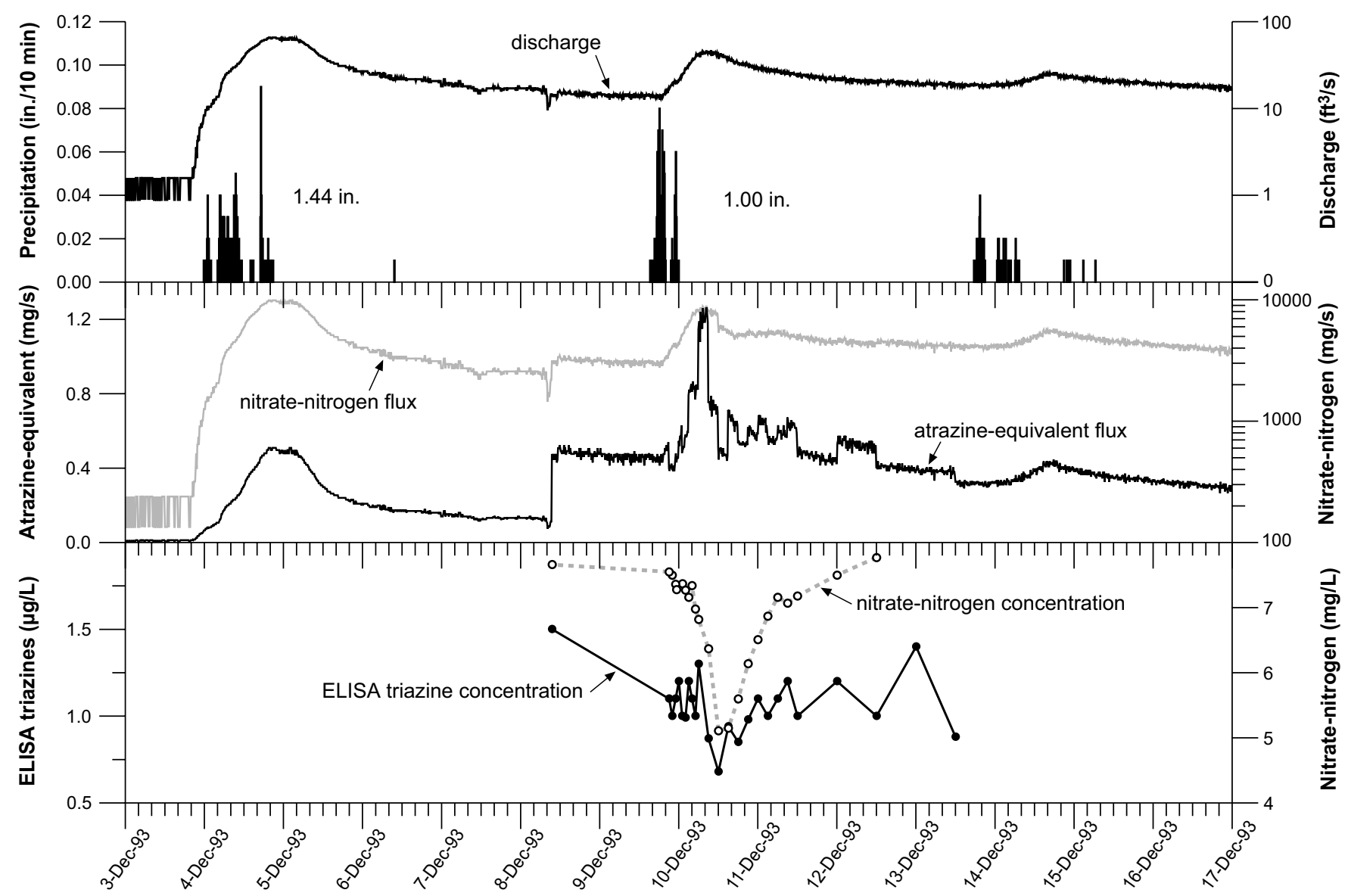

Figure 21. Discharge hydrograph and chemographs showing elevated atrazine-equivalent triazine flux during an early-winter high-flow event at Pleasant Grove Spring.

lected at 23:45 on April 29, 1994, during an event that began with only $0.70 \mathrm{in} .(1.7 \mathrm{~cm})$ of rain at Pleasant Grove Spring, although more rain may have fallen in the basin headwaters. Farm fields that are plowed are highly vulnerable to soil loss between the time they are tilled and before crops have grown sufficiently to provide cover. Although most fields in the Pleasant Grove Spring Basin are no-till or minimum tillage, a number of fields are plowed by conventional methods. The months between March and June consistently have the highest suspended sediment concentrations. The April 29 event is also an excellent example of the dilution of nitrate concentrations and the enhancement of pesticide concentrations by the arrival of runoff at the spring.

\section{Conclusions}

The Pleasant Grove Spring ground-water basin was determined by ground-water dye tracing to cover approximately 10,054 acres ( 4,069 hc). Roughly 70 percent of the basin is crop land, and 22 percent is pasture. About
3,300 acres $(1,335 \mathrm{hc})$ of corn is grown in a 2-year rotation with wheat and soybeans. Significant numbers of beef cattle, dairy cattle, and swine are raised. Nonagricultural activities in the basin are minimal.

The Pleasant Grove Spring ground-water basin has mature karst topography and is characterized by sinkholes, sinking streams, springs, and karst windows. Upper Pleasant Grove Creek loses flow underground to Pleasant Grove Spring during base-flow conditions, but it does not go outside the basin. The Canyon karst window represents a major ground-water sub-basin. Conversely, Leslie Page karst window is a perched and isolated interior sub-basin. A potentiometric groundwater surface map (Plate 2) and dye traces indicate that the basin can be divided into two ground-water flow regimes: slow (diffuse) and fast (conduit). Flow rates in the fast-flow regime are measured in days, whereas flow rates in the slow-flow regime are measured in weeks. The slow-flow regime slowly releases from storage constituents that are dissolved in ground water. 


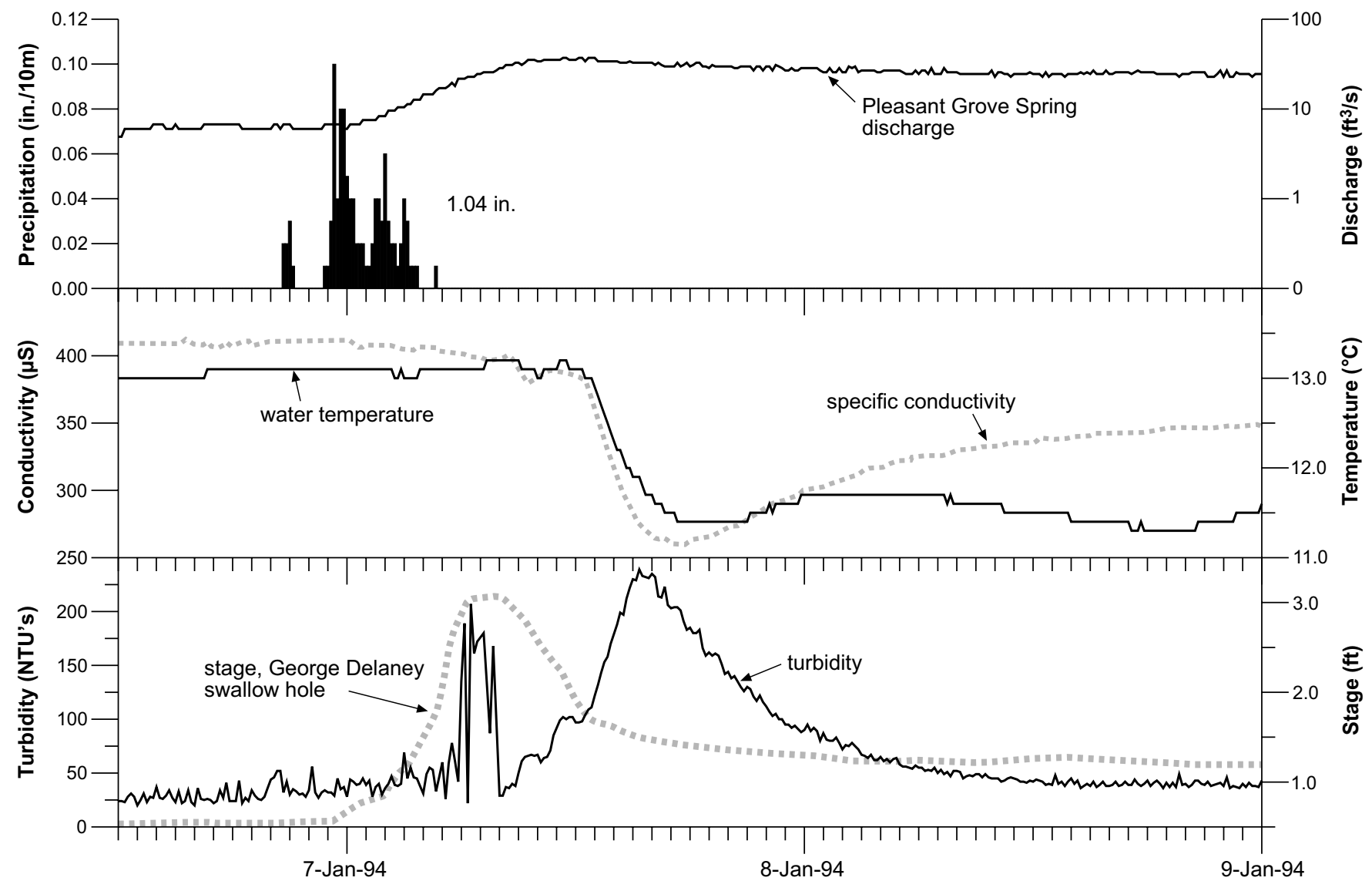

Figure 22. Stage hydrograph for George Delaney swallow hole and discharge hydrograph and chemographs for Pleasant Grove Spring, illustrating flow travel time from George Delaney swallow hole.

Analysis of water samples collected during the first year of study was used to identify contaminants of potential concern. Results suggest that nonpoint-source pollution from agriculture is ubiquitous in the ground water of the Pleasant Grove Spring karst ground-water basin. Contaminants of concern are triazine herbicides and bacteria. Nutrients such as nitrate and orthophosphate are also present in higher than natural concentrations, but generally do not exceed drinking-water standards. Nitrate-nitrogen concentrations throughout the study period in the basin vary narrowly from a minimum of $0.02 \mathrm{mg} / \mathrm{L}$ (lower detection limit) to a maximum of $10.8 \mathrm{mg} / \mathrm{L}$, and average $5.26 \mathrm{mg} / \mathrm{L}$. Nitrate-nitrogen concentrations in forested areas are as low as $0.61 \mathrm{mg} / \mathrm{L}$ (Boyer and Pasquarell, 1994). Sediment is an episodic environmental pollutant. Volatile organic compounds were absent from two samples collected at Leslie Page karst window and two samples from Pleasant Grove Spring. Heavy-metal concentrations in the basin are below maximum contaminant levels for drinking-water.
Concentrations of some pesticides exceed drinkingwater standards at Pleasant Grove Spring during storms in the planting season. Triazine concentrations as high as $44 \mu \mathrm{g} / \mathrm{L}$ have been measured. Carbofuran, metolachlor, and alachlor are found in concentrations substantially above detection limits only during the planting season. Maximum concentrations detected were 7.4,9.6, and $6.1 \mu \mathrm{g} / \mathrm{L}$, respectively. Low triazine concentrations $(0.5$ to $1.5 \mu \mathrm{g} / \mathrm{L})$ persist in the ground water through the remainder of the year.

The annual mass flux of atrazine-equivalent triazines and nitrate-nitrogen was estimated for Pleasant Grove Spring. Atrazine-equivalent losses in 1992-93 were 0.033 $\mathrm{lb} /$ acre $(0.037 \mathrm{~kg} / \mathrm{hc})$ or 1.65 percent of atrazine applied, resulting in a flow-weighted average of $4.91 \mu \mathrm{g} / \mathrm{L}$. Atrazine-equivalent loss in 1993-94 was at a flow-weighted average of $0.97 \mu \mathrm{g} / \mathrm{L}$ (1.0 percent of applied atrazine). Mass flux of other pesticides was substantially less. Nitrate-nitrogen losses for 1992-93 were $15.86 \mathrm{lb} /$ acre $(17.7 \mathrm{~kg} / \mathrm{hc})$ or 11.5 percent of nitrate-nitrogen applied to crops in the basin. Losses of nitrate-nitrogen were $64.7 \mathrm{lb} /$ acre $(72.5 \mathrm{~kg} / \mathrm{hc})$ or 47.2 percent of nitrate-ni- 


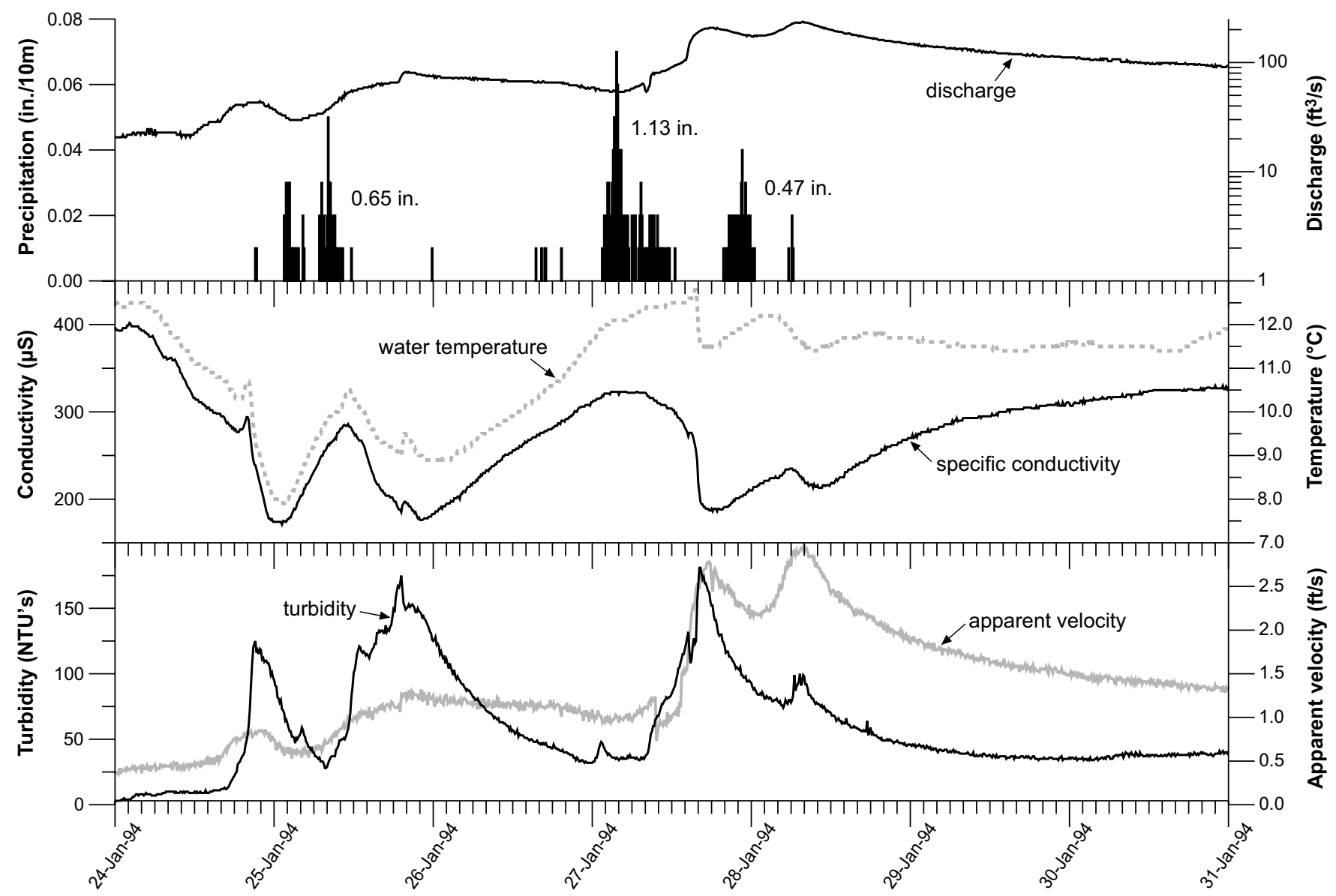

Figure 23. Chemographs and discharge hydrograph for Pleasant Grove Spring, illustrating the discordance of the occurrence of turbidity relative to velocity increases.

trogen applied in 1993-94. The smaller atrazine-equivalent loss and greater nitrate-nitrogen loss may be caused by changes in application rates or by wetter weather conditions in 1993-94 than 1992-93.

The annual mass flux of nitrate-nitrogen at Pleasant Grove Spring is apparently low, in comparison to the Big Spring Basin in Iowa (Hallberg and others, 1984) and considering the significant application of nitratenitrogen in the watershed. The cause of the low flux is not understood, but at least three hypotheses are possible. Harvest may export large amounts of nitrogen from the basin. If this is the case, farmers are managing nitrogen use well and maximizing crop uptake. Crop residue left on the fields may be responsible for the slight increase in nitrate observed during the wet winter and early spring months prior to rapid plant growth. A second hypothesis is that the apparently iron-rich soils may be sorbing, then later releasing, nitrogen (Thomas, 1972). The third hypothesis is that the nitrate is remaining stored, in solution, in ground water in the slow-flow zone of the aquifer. This hypothesis is strongly sup- ported by the concentration trends of other water-quality parameters. Whatever the mechanism, it is strongly moderating nitrate concentrations, which show only modest changes over the course of a year.

Average bacteria counts in the Pleasant Grove Spring Basin are always above drinking-water standards, and occasionally are above water-supply limits, suggesting that ground water in the basin is unsafe for human consumption without sanitization. Bacteria counts at Pleasant Grove Spring of samples collected during both phase I and phase II averaged $550 \mathrm{col} / 100 \mathrm{ml}$ fecal coliform and 2,550 col/100 $\mathrm{ml}$ fecal streptococci. Basinwide, samples averaged $465 \mathrm{col} / 100 \mathrm{ml}$ fecal coliform and $1,891 \mathrm{col} / 100 \mathrm{ml}$ fecal streptococci; maximum counts were 14,000 and $24,000 \mathrm{col} / 100 \mathrm{ml}$, respectively. Unfortunately, Enterococcus speciation analysis and sampling for optical brightener failed to identify the source of the bacteria. Fecal coliform and fecal streptococci counts shift between ratios indicating animal and human sources, depending on flow. Bacteria levels were lower after a facility to handle animal waste was installed on Upper Pleasant Grove Creek. High strepto- 


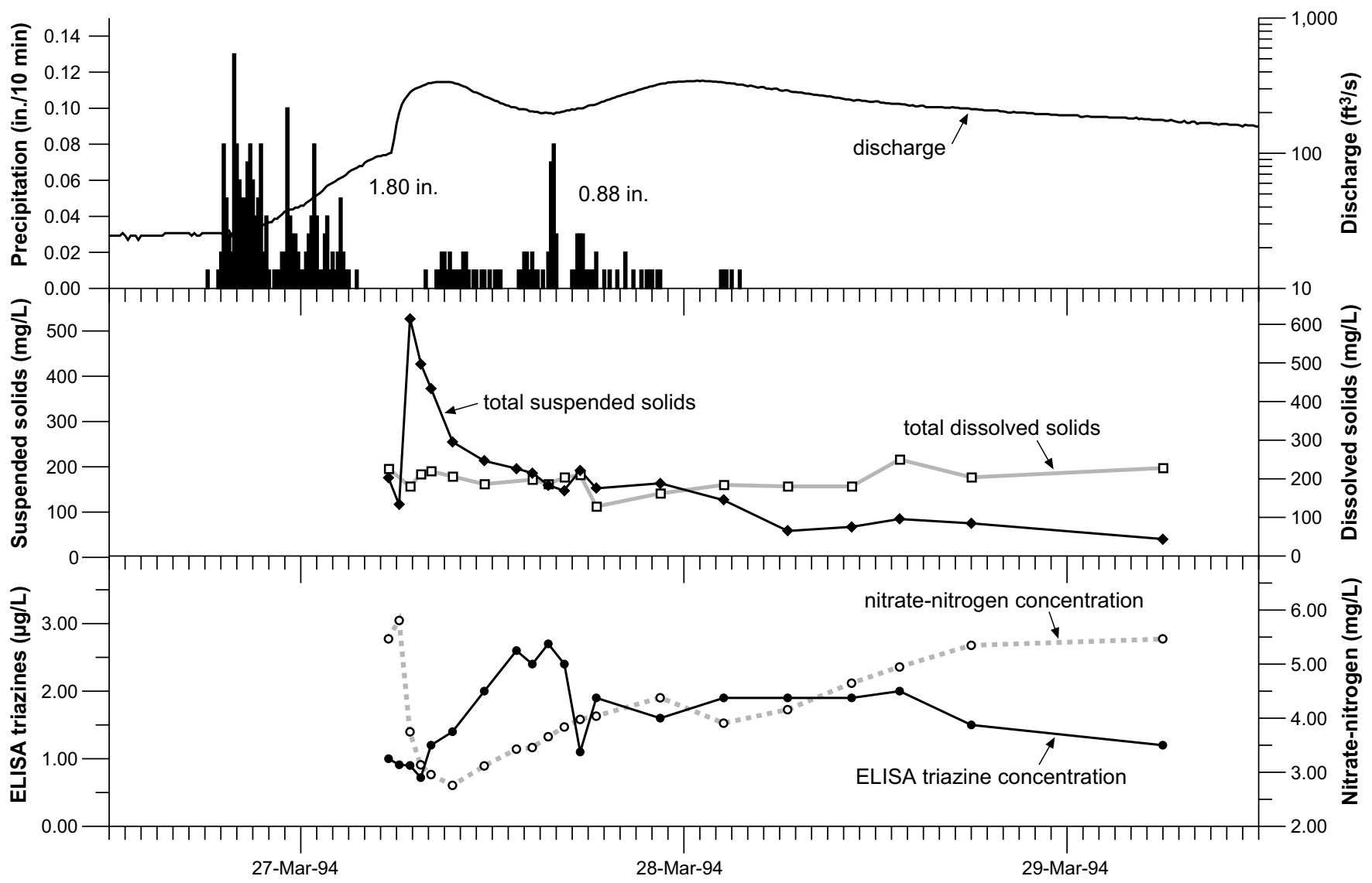

Figure 24. Discharge hydrograph and chemographs for the March 1994 high-flow event at Pleasant Grove Spring showing the discordance of triazine concentration (determined by ELISA) and both dissolved and suspended solids.

cocci counts followed by high coliform counts suggest animal waste is mobilized early in a high-flow event, followed by mobilization of human waste later in the event.

Monitored high-flow events reveal the complex interrelationship of chemical application, tillage, and weather to contaminant transport. Peaks in atrazineequivalent triazine flux are clearly associated with waters originating as field runoff, which enters the ground at swallow holes. The travel time for pesticides in runoff from the headwaters of the basin to Pleasant Grove Spring is less than a day. This is supported by other water-quality parameters associated with the higher pesticide concentration such as temperature changes, reduced conductivity, and increased turbidity. Analysis of filtered and unfiltered sample splits shows no apparent difference in concentration of pesticides, however. Also, the late arrival of higher nitrate concentrations and the stabilization of triazine concentrations to pre-event levels support the model of a diffuse-flow zone storing chemicals and moderating water-quality changes.

\section{SUMmaRY}

This report covers field work conducted between August 1990 and October 1994. During phase I, the area and hydrology of the Pleasant Grove Spring karst ground-water basin were delineated, land use in the basin was mapped, and contaminants were identified. During phase II, monitoring sites were instrumented and pre-BMP monitoring began. The monitoring included collection of data during storms. Also, wells were inventoried and water levels were measured in wells in order to construct a potentiometric map. BMP implementation is now under way.

Pollutants in concentrations of environmental and human health concern occur in ground water in the Pleasant Grove Spring karst drainage basin. Most of these pollutants stem directly from, or are closely associated with, use in agriculture. Although concentrations 


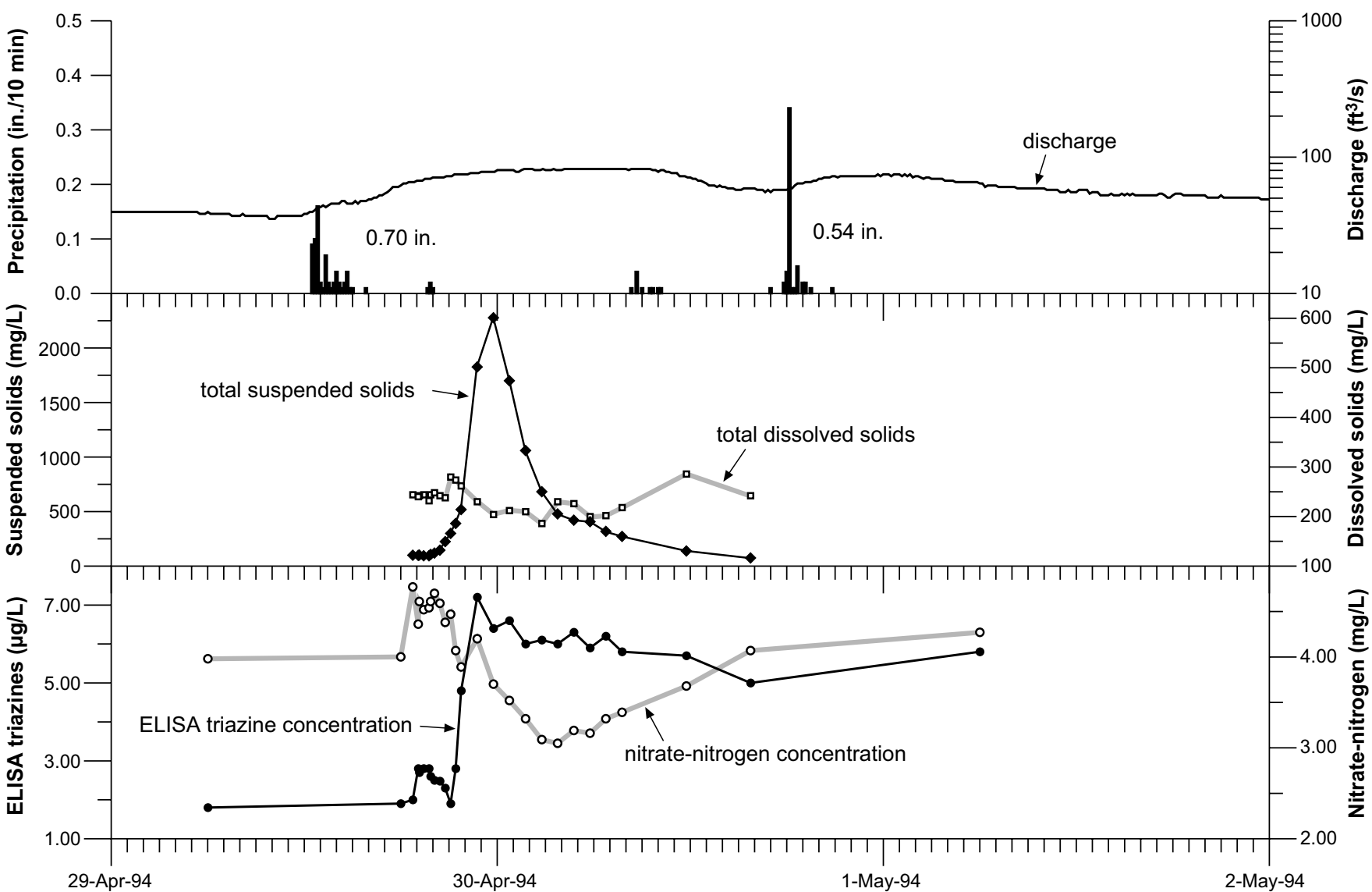

Figure 25. Discharge hydrograph and chemographs for the April 29, 1994, high-flow event at Pleasant Grove Spring.

of atrazine above drinking-water limits generally occur only after significant rainfall immediately following the planting season (when many pesticides are applied), and are associated with ground water originating as direct run-in, the peak atrazine concentrations are of environmental concern. Nitrate losses, though not an ecological problem, suggest significant economic loss to farmers. Bacteria counts improved after a facility to handle animal waste was installed, but remain a concern for drinking-water. Sediment is a major pollutant, but remains unquantified.

The hydrogeology of the basin is a significant controlling influence on the temporal variation of contaminant concentrations. The fast-flow conduit region is characterized by intermediate concentrations of nitrate and pesticides during low flow but substantially higher concentrations of triazines and lower concentrations of nitrate during high flow. The diffuse (slow) flow regime, which is estimated to represent slightly less than half of the basin, drains into the area dominated by conduit flow. The diffuse-flow region has persistently higher concentrations of nitrate but lower, less variable concentrations of triazines. The diffuse, slow-flow area is acting as a reservoir of agricultural chemicals, maintaining a background level of triazines and nitrate during low flow in the conduit-flow regime. Triazine concentrations are significantly higher during high flow, while nitrate concentrations are diluted.

Both municipal and domestic water supplies derived from ground water can be adversely affected. BMP implementation in the basin should focus on controlling animal waste, controlling crop field runoff with associated sediment and pesticide loss, and using more efficient methods of applying nutrients. A strong education program on ground-water protection is highly recommended. 


\section{References Cited}

Aley, Tom, and Fletcher, M.W., 1976, The water tracer's cookbook: Missouri Speleology, v. 16, no. 6, 36 p.

Alhajjar, B.J., 1990, Indicators of chemical pollution from septic systems: Ground Water, v. 28, no. 4, p. 559568.

Ashton, K., 1966, The analysis of flow data from karst drainage systems: Transactions of the Cave Research Group of Great Britain, v. 7, p. 161-203.

Atkinson, T.C., 1973, Experiments in tracing underground waters in limestone: Journal of Hydrology, v. 19 , p. 323-349.

Baker, J.L., 1980, Agricultural areas as nonpoint sources of pollution, in Overcash, M.R., and Davidson, J.M., eds., Environmental impact of nonpoint source pollution: Ann Arbor, Mich., Ann Arbor Science Publishers, p. 275-303.

Baker, J.L., Johnson, H.P., Borcherding, M.A., and Payne, W.R., 1978, Nutrient and pesticide movement from field to stream-A field study, in Best management practices for agriculture and silviculture: Ann Arbor, Mich., Ann Arbor Science Publishers, p. 213-245.

Boyer, D.G., and Pasquarell, G.C., 1994, Agricultural land use impacts on karst ground water quality, in Effects of human-induced changes on hydrologic systems: American Water Resources Association, p. 791-799.

Brown, C.J., 1985, Effects of ground water recharge on nitrate- $\mathrm{N}$ concentrations in a conduit flow-dominated carbonate aquifer in the Sinking Valley groundwater basin, south-central Kentucky: Richmond, Eastern Kentucky University, master's thesis, 145 p.

Brown, R.F., and Lambert, T.W., 1962, Availability of ground water in Allen, Barren, Edmonson, Green, Hart, Logan, Metcalfe, Monroe, Simpson, and Warren Counties, Kentucky: U.S. Geological Survey Hydrologic Investigations Atlas HA-32, 3 plates, scale 1:125,000.

Buchanan, T.J., and Somers, W.P., 1976, Discharge measurements at gaging stations, in Techniques of water-resources investigations of the United States Geological Survey: U.S. Geological Survey, Applications of Hydraulics, book 3, chapter A8, 65 p.

Canter, L.W., 1987, Nitrates and pesticides in ground water-An analysis of a computer-based literature search, in Fairchild, D.M., ed., Ground-water quality and agricultural practices: Chelsea, Mich., Lewis Publishers, p. 153-174.

Canter, L.W., and Knox, R.C., 1985, Septic tank system effects on ground water quality: Chelsea, Mich., Lewis Publishers, $336 \mathrm{p}$.

Cohen, S.Z., Eiden, C., and Lorber, M.N., 1986, Monitoring ground water for pesticides, in Garner, W.Y., Honeycutt, R.C., and Nigg, H.N., eds., Evaluation of pesticides in ground water: American Chemical Society Symposium Series 315, p. 170-196.

Crawford, N.C., 1986, Karst hydrologic problems associated with urban development-Ground-water contamination, hazardous fumes, sinkhole flooding, and sinkhole collapse in the Bowling Green area, Kentucky, in Environmental problems in karst terranes and their solutions: National Water Well Association, Eastern Kentucky University, Friends of the Karst, Kentucky Division of Water, National Park Service, and Western Kentucky University, Field Trip B, 85 p.

Cupp, J.D., 1994, Geomorphic analysis as a predictive tool in determining ground-water flow patterns in the Mississippian Plateau Region of Kentucky: Lexington, University of Kentucky, master's thesis, 98 p.

Currens, J.C., 1993, Characterization and quantification of nonpoint-source pollutant loads in the Pleasant Grove Spring Basin, Logan County, Kentucky-A conduit-flow-dominated karst aquifer underlying an intensive-use agricultural region: Kentucky Geological Survey, Open-File Report OF-93-07, 78 p.

Dao, T.H., Lavy, T.L., and Sorensen, R.C., 1979, Atrazine degradation and residue distribution in soil: Soil Science Society of America Journal, v. 43, p. 11291133.

Davis, S.N., Campbell, D.J., Bentley, H.W., and Flynn, T.J., 1985, Ground-water tracers: U.S. Environmental Protection Agency-Office of Research and Development and National Water Well Association, 200 p.

Devilbiss, T.S., 1981, An investigation into the movement of an agricultural pesticide within the groundwater system of a karst swallet: Richmond, Eastern Kentucky University, master's thesis, 99 p.

Dye, J.W., Barton, A.J., and Froedge, R.D., 1975, Soil survey of Logan County, Kentucky: U.S. Department of Agriculture-Soil Conservation Service, in cooperation with the Kentucky Agricultural Experiment Station-National Cooperative Soil Survey, $78 \mathrm{p}$.

Felton, G.K., 1991, Agricultural chemicals at the outlet of a shallow carbonate aquifer: American Society of 
Agricultural Engineers, 1991 International Summer Meeting, Albuquerque, N. Mex., paper 91-2109, 26 p.

Hall, J.K., Pawlus, M., and Higgins, E.R., 1972, Losses of atrazine in runoff water and soil sediment: Journal of Environmental Quality, v. 1, no. 2, p. 172-176.

Hallberg, G.R., Hoyer, B.E., Bettis, E.A., III, and Libra, R.D., 1983, Hydrogeology, water quality, and land management in the Big Spring Basin, Clayton County, Iowa: Iowa Geological Survey, Open-File Report 83-3, $191 \mathrm{p}$.

Hallberg, G.R., Libra, R.D., Bettis, E.A., III, and Hoyer, B.E., 1984, Hydrogeologic and water quality investigations in the Big Spring Basin, Clayton County, Iowa: Iowa Geological Survey, Open-File Report 84-4, $231 \mathrm{p}$.

Hampson, S.K., 1994, The impact of agricultural practices on epikarstic ground-water quality in the Inner Bluegrass Region in Kentucky: Lexington, University of Kentucky, master's thesis, $311 \mathrm{p}$.

Haszler, G.R., 1993, Water quality assessment in agricultural areas of Kentucky; surface- and ground-water report, October 1992-September 1993: University of Kentucky, Committee on Water Quality Assessment, $188 \mathrm{p}$.

Johnston, W.R., Ittihadieh, F.T., Craig, K.R., and Pillsbury, A.F., 1967, Insecticides in tile drainage effluent: Water Resources Research, v. 3, no. 2, p. 525537.

Jones, W.K., 1984, Dye tracer tests in karst areas: The NSS Bulletin, Journal of Caves and Karst Studies, v. 46 , no. 2, p. 3-9.

Keagy, D.M., Dinger, J.S., Fogle, A.W., and Sendlein, L.V.A., 1994a, Interim report on the effect of pesticides, nitrate, and bacteria on ground-water quality in a karst terrain in the Inner Blue Grass Region, Woodford County, Kentucky: Kentucky Geological Survey, Open-File Report OF-93-04, 46 p.

Keagy, D.M., Dinger, J.S., Hampson, S.K., and Sendlein, L.V.A., 1994b, Interim report on the effect of fractures on the quantity of ground water and the occurrence of pesticides and nutrients in the epikarst of the Inner Blue Grass Region, Bourbon County, Kentucky: Kentucky Geological Survey, Open-File Report OF93-05, 31 p.

Kentucky Agricultural Statistics Service, 1993, Kentucky agricultural statistics, 1992: Louisville, Kentucky Agricultural Statistics Service, 143 p.
Kentucky Division of Water, 1988, 1988 Kentucky report to Congress on water quality: Kentucky Natural Resources and Environmental Protection Cabinet, $150 \mathrm{p}$.

Libra, R.D., 1987, Impacts of agricultural chemicals on ground-water quality in Iowa, in Fairchild, D.M., ed., Ground-water quality and agricultural practices: Chelsea, Mich., Lewis Publishers, p. 185-215.

Libra, R.D., Hallberg, G.R., Hoyer, B.E., and Johnson, L.G., 1986, The Big Spring Basin Study, Iowa, in Agricultural impacts on ground water, a conference: National Water Well Association, p. 253-273.

Lichtenstein, E.P., 1958, Movement of insecticides in soils under leaching and non-leaching conditions: Journal of Economic Entomology, v. 51, no. 3, p. 380-383.

Magette, W.L., Weismiller, R.A., Angle, J.S., and Brinsfield, R.B., 1988, Nitrate standard for ground water beneath agricultural production areas: American Society of Agricultural Engineers paper 88-2642, $16 \mathrm{p}$.

Martin, J.R., and Green, J.D., 1992, Chemical control of weeds in Kentucky farm crops-1992: University of Kentucky College of Agriculture-Cooperative Extension Service, $87 \mathrm{p}$.

Meiman, J., 1985, Investigation of flood pulse movement through a maturely karstified aquifer at Mammoth Cave National Park: Richmond, Eastern Kentucky University, master's thesis, $343 \mathrm{p}$.

Meiman, J., 1991, The effects of recharge basin land-use practices on water quality at Mammoth Cave National Park, Kentucky, in Proceedings of the Third Conference on Hydrogeology, Ecology, Monitoring, and Management of Ground Water in Karst Terrains, December 4-6, 1991, Nashville, Tenn.: U.S. Environmental Protection Agency and the Association of Ground Water Scientists and Engineers, p. 697-714.

Miller, R.C., 1968, Geologic map of the Russellville quadrangle, Logan County, Kentucky: U.S. Geological Survey Geologic Quadrangle Map GQ-714, scale 1:24,000.

Mull, D.S., Smoot, J.L., and Liebermann, T.D., 1988, Dyetracing techniques used to determine ground-water flow in a carbonate aquifer system near Elizabethtown, Kentucky: U.S. Geological Survey Water-Resources Investigations Report 87-4174, 95 p.

Mylroie, J.E., 1984, Oakville Cave, in Western Kentucky speleological survey, annual report 1984: Murray 
State University-College of Environmental Sciences, scale 1:462.

Nitzkin, J.L., and Henry, M.H., 1971, Infectious hepatitis in Logan County, Kentucky; a probable common source outbreak: Journal of the Kentucky Medical Association, p. 349-353.

Ogden, A.E., 1988, Distinguishing flow regimes of springs in carbonate rock terrains, in Lehr, J.H., ed., Proceedings, Association of Ground Water Scientists and Engineers, Ground Water Geochemistry Conference, February 16-18, 1988: National Water Well Association, p. 53-73.

Ohmicron, Corp., 1991, Atrazine RaPID assay [technical bulletin accompanying test kit]: Newtown, Pa., Ohmicron Corp., 2 p.

Palmer, A.N., 1981, A geological guide to Mammoth Cave National Park: Teaneck, N.J., Zephyrus Press, $196 \mathrm{p}$.

Quinlan, J.F., ed., 1987, Qualitative water-tracing with dyes in karst terrains-Practical karst hydrogeology, with emphasis on groundwater monitoring: National Water Well Association, $26 \mathrm{p}$.

Quinlan, J.F., and Alexander, E.C., Jr., 1987, How often should samples be taken at relevant locations for reliable monitoring of pollutants from an agricultural, waste disposal, or spill site in a karst terrain, in Proceedings of the Second Multidisciplinary Conference on Sinkholes and the Environmental Impacts of Karst, Orlando, Fla., February 9-11, 1987: Boston, A.A. Balkema, p. 277-286.

Rainey, H.C., III, 1965, Geologic map of the Dennis quadrangle, Logan County, Kentucky: U.S. Geological Survey Geologic Quadrangle Map GQ-450, scale 1:24,000.

Sampson, W.F., 1995, Biological survey of Pleasant Grove Spring, Logan County, Kentucky, for "Characterization and Quantification of Nonpoint-Source Pollutant Loads in a Karst Aquifer Underlying an Agricultural Region": Kentucky Division of WaterWater Quality Branch, $10 \mathrm{p}$.

Sharpley, A.N., and Syers, J.K., 1979, Phosphorus inputs into a stream draining an agricultural watershed: Water, Air, and Soil Pollution, v. 11, p. 417-428.

Shawe, F.R., 1966a, Geologic map of the Adairville quadrangle, Kentucky-Tennessee: U.S. Geological Survey Geologic Quadrangle Map GQ-569, scale 1:24,000.
Shawe, F.R., 1966b, Geologic map of the Dot quadrangle, Kentucky-Tennessee: U.S. Geological Survey Geologic Quadrangle Map GQ-568, scale 1:24,000.

Smart, P.L., 1984, A review of the toxicity of twelve fluorescent dyes used for water tracing: The NSS Bulletin, Journal of Caves and Karst Studies, v. 46, no. 2, p. 21-33.

Smith, M.C., Bottcher, A.B., Campbell, K.L., and Thomas, D.L., 1988, Measurement of pesticide transport to shallow groundwater: American Society of Agricultural Engineers paper 88-2640, 42 p.

Steele, K.F., and Smith, C.R., 1994, Hydrochemistry and water quality of two primary carbonate aquifers, Ozark Plateaus Province, in Effects of humaninduced changes on hydrologic systems: American Water Resources Association, p. 1147-1156.

Thomas, G.W., 1972, The relation between soil characteristics, water movement, and nitrate contamination of ground water: University of Kentucky-Kentucky Water Resources Research Institute, Research Report 140, $31 \mathrm{p}$.

Thomas, G.W., and Phillips, R.E., 1979, Consequences of water movement in macropores: Journal of Environmental Quality, v. 8, no. 2, p. 149-152.

Thrailkill, John, Byrd, P.E., Sullivan, S.B., Spangler, L.E., Taylor, C.J., Nelson, G.K., and Pogue, K.R., 1983, Studies in dye-tracing techniques and karst hydrogeology: University of Kentucky-Kentucky Water Resources Research Institute, Research Report 140, $89 \mathrm{p}$.

Thurman, E.M., Meyer, M., Pomes, M., Perry, C.A., and Schwab, A.P., 1990, Enzyme-linked immunosorbent assay compared with gas chromatography/mass spectrometry for the determination of triazine herbicides in water: Analytical Chemistry, v. 62, no. 18, p. 2043-2048.

Tucker, N.L., 1982, Nonpoint agricultural pollution in a karst aquifer: Lost River groundwater basin, Warren County, Kentucky: Bowling Green, Western Kentucky University, master's thesis, $91 \mathrm{p}$.

U.S. Environmental Protection Agency, 1983, Handbook for sampling and sample preservation of water and waste water: U.S. Environmental Protection Agency, EPA-600/4-82/029, 402 p.

U.S. Environmental Protection Agency, 1989, Method 407. Determination of nitrogen- and phosphoruscontaining pesticides in water by gas chromatography with a nitrogen-phosphorus detector, revision 
2.0, in Methods for the determination of organic compounds in drinking water: U.S. Environmental Protection Agency, Environmental Monitoring Systems Laboratory, Office of Research and Development, EPA/600/4-88/039, p. 143-146.

U.S. Geological Survey, 1982, U.S. Geological Survey national handbook of recommended methods for water-data acquisition; chapter 5 , chemical and physical quality of water and sediment: U.S. Geological Survey, p. 5-1-5-194.

Van Couvering, J.A., 1962, Characteristics of large springs in Kentucky: Kentucky Geological Survey, ser. 10, Information Circular 8, 37 p.
Verduin, J., 1970, Significance of phosphorus in water supplies, in Willrich, T.L., and Smith, G.E., ed., Agricultural practices and water quality: Ames, Iowa State University Press, p. 63-71.

Wartenberg, D., 1988, Groundwater contamination by Temik aldicarb pesticide; the first eight months: Water Resources Research, v. 24, no. 2, p. 185-194.

White, A.W., Barnett, A.P., Wright, B.G., and Holladay, J.H., 1967, Atrazine losses from fallow land caused by runoff and erosion: Environmental Science and Technology, v. 1, no. 9, p. 740-744.

White, W.B., 1988, Geomorphology and hydrology of karst terrains: Oxford, Oxford University Press, 464 p. 


\section{Appendix A:}

Discharge Observations of Springs and Streams in the Pleasant Grove Spring Drainage Basin 
Pleasant Grove Spring

\begin{tabular}{|c|c|c|c|c|}
\hline Date & Time (CST) & Conditions & Stage (ft) & $\begin{array}{c}\text { Discharge } \\
\left(\mathrm{ft}^{3} / \mathrm{s}\right)\end{array}$ \\
\hline Aug/02/1990 & 11:00 & & & 1.30 \\
\hline Feb/28/1991 & $9: 10$ & & & 51.20 \\
\hline Apr/09/1991 & $14: 45$ & & & 47.50 \\
\hline Apr/09/1991 & $15: 28$ & & & 44.93 \\
\hline Apr/11/1991 & $13: 40$ & & & 44.76 \\
\hline Apr/11/1991 & $14: 38$ & & & 41.93 \\
\hline Apr/11/1991 & $12: 20$ & & & 41.70 \\
\hline May/01/1991 & $10: 17$ & & & 19.70 \\
\hline May/22/1991 & $12: 23$ & & & 37.70 \\
\hline Jun/26/1991 & $11: 24$ & & & 22.40 \\
\hline Jul/25/1991 & $11: 20$ & & & 5.55 \\
\hline Aug/29/1991 & $13: 40$ & & & 2.53 \\
\hline Sep/24/1991 & $10: 46$ & & & 1.85 \\
\hline Oct/22/1991 & $8: 50$ & & & 1.50 \\
\hline $\mathrm{Dec} / 17 / 1991$ & $8: 06$ & falling & 2.42 & 59.40 \\
\hline Jan/29/1992 & $10: 50$ & stable & 1.85 & 11.98 \\
\hline Feb/26/1992 & $11: 50$ & stable & 1.96 & 14.92 \\
\hline Mar/25/1992 & $13: 55$ & stable & 2.00 & 32.65 \\
\hline Apr/29/1992 & $11: 10$ & falling & 1.89 & 7.42 \\
\hline May/27/1992 & $11: 45$ & stable & 1.80 & 1.90 \\
\hline Jun/03/1992 & $15: 20$ & rising & 1.93 & 11.64 \\
\hline Jun/04/1992 & $14: 10$ & falling & 2.36 & 48.66 \\
\hline Jun/18/1992 & $8: 20$ & falling & 1.88 & 12.76 \\
\hline Jul/22/1992 & $17: 00$ & rising & 1.74 & 7.52 \\
\hline Jul/23/1992 & $13: 50$ & falling & 1.74 & 5.93 \\
\hline Aug/26/1992 & $11: 10$ & falling & 1.66 & 2.96 \\
\hline Oct/06/1992 & $15: 40$ & falling & 1.64 & 2.63 \\
\hline Nov/06/1992 & 9:00 & falling & 1.68 & 2.46 \\
\hline $\mathrm{Dec} / 02 / 1992$ & $9: 50$ & falling & 1.76 & 2.82 \\
\hline Jan/07/1993 & $16: 00$ & stable & 2.06 & 24.15 \\
\hline Jan/08/1993 & $12: 20$ & falling & 2.06 & 22.33 \\
\hline Feb/04/1993 & $11: 40$ & falling & 1.90 & 12.41 \\
\hline Mar/03/1993 & $10: 10$ & falling & 2.50 & 55.47 \\
\hline Apr/07/1993 & $9: 10$ & falling & 2.17 & 29.36 \\
\hline May/04/1993 & $13: 10$ & falling & 4.24 & 188.34 \\
\hline May/05/1993 & $10: 10$ & falling & 3.08 & 88.64 \\
\hline May/05/1993 & $12: 10$ & falling & 3.04 & 111.30 \\
\hline Aug/04/1993 & $10: 00$ & stable & 1.66 & 3.04 \\
\hline Sep/09/1993 & $7: 50$ & falling & 1.62 & 1.84 \\
\hline Oct/06/1993 & $7: 00$ & falling & 1.61 & 1.74 \\
\hline Nov/09/1993 & $11: 40$ & falling & 1.64 & 1.36 \\
\hline Mar/28/1994 & $15: 22$ & falling & 4.42 & 128.94 \\
\hline Apr/11/1994 & $13: 52$ & stable & 7.45 & 463.38 \\
\hline Apr/11/1994 & $18: 17$ & falling & 7.13 & 434.88 \\
\hline Apr/11/1994 & $14: 24$ & falling & 7.30 & 457.53 \\
\hline Apr/12/1994 & $9: 00$ & falling & 5.52 & 237.35 \\
\hline Aug/03/1994 & $9: 20$ & stable & 1.68 & 3.67 \\
\hline
\end{tabular}


Spring Valley karst window

\begin{tabular}{|l|c|l|c|c|}
\hline Date & Time $($ CST) & Conditions & Stage $(\mathrm{ft})$ & $\begin{array}{c}\text { Discharge } \\
\left(\mathrm{ft}^{3} / \mathrm{s}\right)\end{array}$ \\
\hline Aug/02/1990 & $10: 21$ & & & 2.39 \\
\hline Feb/28/1991 & $10: 51$ & & & 58.90 \\
\hline Apr/09/1991 & $10: 24$ & & & 32.40 \\
\hline Apr/11/1991 & $10: 46$ & & & 45.50 \\
\hline Jun/26/1991 & $12: 00$ & & & 20.08 \\
\hline Jul/25/1991 & $10: 30$ & & & 5.23 \\
\hline Aug/29/1991 & $12: 40$ & & & 2.80 \\
\hline Sep/24/1991 & $9: 24$ & & & 2.36 \\
\hline Oct/22/1991 & $9: 30$ & & & 4.50 \\
\hline Jan/29/1992 & $10: 00$ & & & 11.82 \\
\hline Feb/26/1992 & $11: 00$ & & & 15.44 \\
\hline Mar/25/1992 & $11: 10$ & & & 29.77 \\
\hline Apr/29/1992 & $9: 36$ & & & 7.40 \\
\hline May/27/1992 & $10: 15$ & & & 2.32 \\
\hline Jul/23/1992 & $12: 50$ & & & 5.80 \\
\hline May/20/1993 & $9: 10$ & falling & 1.18 & 16.19 \\
\hline Jun/02/1993 & $12: 20$ & stable & 1.10 & 12.87 \\
\hline Jun/17/1993 & $8: 50$ & falling & 0.83 & 6.77 \\
\hline Jun/30/1993 & $11: 10$ & falling & 0.79 & 5.05 \\
\hline Sep/07/1993 & $14: 20$ & stable & 0.72 & 1.80 \\
\hline Nov/08/1993 & $16: 20$ & stable & 1.08 & 1.28 \\
\hline Dec/07/1993 & $16: 44$ & falling & 1.54 & 21.95 \\
\hline
\end{tabular}

The Canyon karst window

\begin{tabular}{|l|c|l|l|c|}
\hline Date & Time (CST) & Conditions & Stage $(\mathrm{ft})$ & $\begin{array}{c}\text { Discharge } \\
\left(\mathrm{ft}^{3} / \mathrm{s}\right)\end{array}$ \\
\hline Aug/02/1990 & $9: 13$ & & & 0.11 \\
\hline May/01/1991 & $9: 31$ & & & 0.13 \\
\hline May/22/1991 & $9: 56$ & & & 8.70 \\
\hline Jun/26/1991 & $8: 58$ & & & 0.13 \\
\hline Jul/25/1991 & $9: 35$ & & & 0.14 \\
\hline Aug/29/1991 & $11: 55$ & & & 0.02 \\
\hline Sep/24/1991 & $8: 40$ & & & 0.01 \\
\hline Jan/29/1992 & $8: 35$ & & & 0.09 \\
\hline Feb/26/1992 & $9: 32$ & & & 0.14 \\
\hline Apr/29/1992 & $8: 40$ & & & 0.10 \\
\hline May/29/1992 & $11: 05$ & & & 0.02 \\
\hline
\end{tabular}


Shackelford Spring

\begin{tabular}{|l|c|l|l|c|}
\hline Date & Time $($ CST) & Conditions & Stage $(\mathrm{ft})$ & $\begin{array}{c}\text { Discharge } \\
\left(\mathrm{ft}^{3} / \mathrm{s}\right)\end{array}$ \\
\hline Feb/28/1991 & $12: 59$ & & & 0.48 \\
\hline May/01/1991 & $8: 05$ & & & 0.57 \\
\hline Jul/25/1991 & $8: 20$ & & & 0.54 \\
\hline Aug/29/1991 & $11: 13$ & & & 0.29 \\
\hline Sep/24/1991 & $7: 48$ & & & 0.12 \\
\hline Dec/17/1991 & $12: 35$ & & & 0.96 \\
\hline Jan/28/1992 & $14: 21$ & & & 0.33 \\
\hline Feb/26/1992 & $8: 47$ & & & 0.78 \\
\hline Mar/25/1992 & $9: 02$ & & & 0.58 \\
\hline Apr/29/1992 & $7: 43$ & & & 0.16 \\
\hline
\end{tabular}

Thad Flowers blue hole

\begin{tabular}{|l|c|l|l|c|}
\hline Date & Time (CST) & Conditions & Stage $(\mathrm{ft})$ & $\begin{array}{c}\text { Discharge } \\
\left(\mathrm{ft}^{3} / \mathrm{s}\right)\end{array}$ \\
\hline Feb/28/1991 & $12: 12$ & & & 0.55 \\
\hline May/01/1991 & $8: 13$ & & & 0.02 \\
\hline May/22/1991 & $7: 17$ & & & 0.20 \\
\hline Dec/17/1991 & $13: 35$ & & & 0.87 \\
\hline Mar/25/1992 & $7: 45$ & & & 0.50 \\
\hline
\end{tabular}

George Delaney swallow hole

\begin{tabular}{|l|c|l|c|c|}
\hline Date & Time (CST) & Conditions & Stage $(\mathrm{ft})$ & $\begin{array}{c}\text { Discharge } \\
\left(\mathrm{ft}^{3} / \mathrm{s}\right)\end{array}$ \\
\hline May/22/1991 & $11: 25$ & & & 8.75 \\
\hline Jun/26/1991 & $9: 45$ & & & 3.15 \\
\hline Jul/25/1991 & $9: 55$ & & & 0.01 \\
\hline Dec/17/1991 & $10: 15$ & & & 18.30 \\
\hline Jan/29/1992 & $9: 17$ & & & 1.64 \\
\hline Feb/26/1992 & $10: 20$ & & & 3.18 \\
\hline Mar/25/1992 & $10: 03$ & & & 10.46 \\
\hline May/20/1993 & $8: 00$ & falling & 1.46 & 2.29 \\
\hline Jun/03/1993 & $8: 50$ & stable & 0.71 & 1.36 \\
\hline Jun/03/1993 & $9: 02$ & stable & 0.71 & 1.26 \\
\hline Jun/17/1993 & $8: 20$ & falling & 0.14 & 0.00 \\
\hline Jun/17/1993 & $8: 15$ & falling & 0.14 & 0.00 \\
\hline Dec/07/1993 & $12: 03$ & falling & 1.07 & 6.15 \\
\hline Jan/11/1994 & $15: 45$ & falling & 1.16 & 10.81 \\
\hline Mar/03/1994 & $8: 26$ & falling & 2.50 & 12.29 \\
\hline Jun/02/1994 & $11: 28$ & stable & 0.68 & 0.60 \\
\hline
\end{tabular}




\section{Leslie Page karst window}

\begin{tabular}{|l|c|l|c|c|}
\hline Date & Time (CST) & Conditions & Stage $(\mathrm{ft})$ & $\begin{array}{c}\text { Discharge } \\
\left(\mathrm{ft}^{3} / \mathrm{s}\right)\end{array}$ \\
\hline May/05/1993 & $9: 20$ & & 0.78 & 0.48 \\
\hline May/20/1993 & $11: 10$ & falling & 0.62 & 0.01 \\
\hline Jun/02/1993 & $10: 10$ & & 0.63 & 0.02 \\
\hline Jun/17/1993 & $9: 50$ & falling & 0.61 & 0.04 \\
\hline Jun/30/1993 & $10: 00$ & falling & 0.59 & 0.00 \\
\hline Sep/07/1993 & $14: 40$ & & 0.50 & 0.25 \\
\hline Oct/05/1993 & $12: 40$ & falling & 0.50 & 0.00 \\
\hline Dec/07/1993 & $16: 07$ & falling & 0.62 & 0.07 \\
\hline Dec/07/1993 & $16: 07$ & falling & 0.62 & \\
\hline Jan/11/1994 & $14: 06$ & stable & 0.72 & 0.08 \\
\hline Feb/02/1994 & $9: 45$ & falling & 0.76 & 0.41 \\
\hline Feb/22/1994 & $13: 34$ & rising & 0.86 & 0.32 \\
\hline
\end{tabular}

Upper Pleasant Grove Creek

\begin{tabular}{|l|c|l|c|c|}
\hline Date & Time $($ CST $)$ & Conditions & Stage $(f t)$ & $\begin{array}{c}\text { Discharge } \\
\left(\mathrm{ft}^{3} / \mathrm{s}\right)\end{array}$ \\
\hline Jun/17/1993 & $7: 40$ & falling & 0.40 & 1.31 \\
\hline Jun/30/1993 & $9: 00$ & & 0.40 & 0.37 \\
\hline Sep/07/1993 & $15: 16$ & stable & 0.18 & 0.00 \\
\hline Dec/07/1993 & $15: 00$ & falling & 1.14 & 9.57 \\
\hline Feb/22/1994 & $15: 27$ & rising & 2.50 & 61.91 \\
\hline
\end{tabular}




\section{ApPEndix B:}

Analytical Methods, Sample Containers, Preservatives, and Holding Times Used for Samples Collected in the Pleasant Grove Spring Basin During Phases I AND II 
Analytical methods for water samples are listed in Table B-1. Comprehensive (C) samples include every analyte on the list except bacteria and field $\mathrm{pH}$, temperature, total alkalinity, and conductivity. Analytes included in base flow (B) and event (E) sampling are indicated under the heading "Analysis Suite." Bacteria, volatile organics, and optical brightener analyses are topical (T) and may be collected by themselves or in conjunction with another analysis suite.

Pesticide concentrations were determined by two methods: gas chromatograph (GC) with either a nitrogen-phosphorus detector (method 507) or electron-capture (method 508), and enzyme-linked immunosorbent assay (ELISA) or immunoassay. All samples collected before April 1992, and some samples collected after that date, were analyzed for pesticides by gas chromatograph. Beginning in April 1992 all samples were also analyzed by ELISA for triazine herbicides (collectively, atrazine, simazine, and cyanazine), alachlor, metolachlor, 2,4-D, and carbofuran. Because there were no results above detection limit for 2,4-D during the first year, analysis for 2,4-D was discontinued. Pesticide results after April 1992 reported in this document are ELISA unless otherwise noted.

The GC method provides a more accurate analysis, but is expensive and therefore used less often. For a few exceptions the reported GC analyses of some pesticides may have a slightly lower detection limit than those listed here. The pesticides determined by gas chromatograph and their detections in micrograms per liter are listed in Table B-2.

The Kentucky Geological Survey water-quality laboratory used Ohmicron "RaPID Assay" ELISA kits for all immunoassay analyses. The following description of the ELISA analytical method is excerpted from Ohmicron Corp. literature (1991) that accompanies each kit and is generally applicable to all Ohmicron kits:
The sample to be tested is added, along with an enzyme conjugate, to a disposable test tube, followed by paramagnetic particles with antibodies specific to triazines attached. Both the atrazine (which may be in the sample) and the enzyme labeled atrazine (the enzyme conjugate) compete for antibody binding sites on the magnetic particles. At the end of an incubation period, a magnetic field is applied to hold the paramagnetic particles (with atrazine and labeled atrazine analog bound to the antibodies on the particles, in proportion to their original concentration) in the tube and allow the unbound reagents to be decanted. After decanting the particles are washed and the enzyme substrate and the chromogen are added. The enzyme-labeled atrazine analog bound to the atrazine antibody catalyzes the conversion of the substrate/chromogen mixture to a colored product. After incubation the reaction is stopped with acid. Since the labeled atrazine was in competition with the unlabeled atrazine for the antibody sites, the color developed is inversely proportional to the concentration of atrazine in the sample.

The intensity of the color change is quantified on a spectrophotometer and the concentration reported in micrograms per liter.

While GC analysis detects specific target pesticides individually, ELISA analysis detects a target pesticide and $a$ few additional chemically related compounds. The ELISA triazine analysis is designed to be most sensitive to atrazine, which it measures above a detection limit of $0.046 \mu \mathrm{g} / \mathrm{L}$, though it also detects simazine (above $0.34 \mu \mathrm{g} / \mathrm{L}$ ) and cyanazine (above $1.0 \mu \mathrm{g} / \mathrm{L}$ ), according to the manufacturer's literature. The method also detects some degradation products of the pesticides. The ELISA triazine results are therefore the total of triazine herbicides and degradation products in the sample. The other ELISA analyses similarly react to a small group of compounds, but are most sensitive to the targeted pesticide. Detection limits by ELISA analysis, as used by the Kentucky Geological Survey water-quality laboratory, are as follows (units are $\mu \mathrm{g} / \mathrm{L}$ ): triazines, 0.06 (standard deviation [SD] 0.08); metolachlor, 0.06 (SD 0.3); 2,4-D, 0.90 (SD 0.16). 
Table B-1. Analytical methods, sample containers, preservatives, and maximum holding times.

Metals, Total

\begin{tabular}{|c|c|c|c|c|c|c|}
\hline Analyte & Container & Preservative & $\begin{array}{l}\text { Holding } \\
\text { Time }\end{array}$ & $\begin{array}{l}\text { Analytical } \\
\text { Procedure }\end{array}$ & $\begin{array}{l}M D L^{*} \\
(\mathrm{mg} / \mathrm{L})\end{array}$ & $\begin{array}{c}\text { Analysis } \\
\text { Suite }\end{array}$ \\
\hline Arsenic & \multirow{17}{*}{ Polyethylene } & \multirow{17}{*}{$\mathrm{HNO}_{3}$, ice } & \multirow{17}{*}{6 months } & \multirow{17}{*}{ EPA 200.7a } & 0.050 & $\mathrm{C}$ \\
\hline Barium & & & & & 0.0007 & $\mathrm{C}$ \\
\hline Calcium & & & & & 0.023 & $\mathrm{C}, \mathrm{E}$ \\
\hline Chromium & & & & & 0.008 & $\mathrm{C}$ \\
\hline Copper & & & & & 0.007 & $\mathrm{C}$ \\
\hline Iron & & & & & 0.006 & $\mathrm{C}$ \\
\hline Lead & & & & & 0.071 & $\mathrm{C}$ \\
\hline Magnesium & & & & & 0.030 & $\mathrm{C}, \mathrm{E}$ \\
\hline Manganese & & & & & 0.002 & $\mathrm{C}$ \\
\hline Nickel & & & & & 0.049 & $\mathrm{C}$ \\
\hline Phosphorus & & & & & 0.121 & $\mathrm{C}$ \\
\hline Potassium & & & & & 1.210 & $\mathrm{C}$ \\
\hline Silicon & & & & & 0.034 & $\mathrm{C}$ \\
\hline Sodium & & & & & 0.018 & $\mathrm{C}$ \\
\hline Strontium & & & & & 0.001 & C \\
\hline Sulfur & & & & & 0.030 & $\mathrm{C}$ \\
\hline Zinc & & & & & 0.004 & $\mathrm{C}$ \\
\hline
\end{tabular}

Metals, Dissolved

\begin{tabular}{|c|c|c|c|c|c|c|}
\hline Analyte & Container & Preservative & $\begin{array}{c}\text { Holding } \\
\text { Time }\end{array}$ & $\begin{array}{l}\text { Analytical } \\
\text { Procedure }\end{array}$ & $\begin{array}{l}M D L^{*} \\
(m g / L)\end{array}$ & $\begin{array}{c}\text { Analysis } \\
\text { Suite }\end{array}$ \\
\hline Arsenic & \multirow{17}{*}{ Polyethylene } & \multirow{17}{*}{$\mathrm{HNO}_{3}$, ice } & \multirow{17}{*}{6 months } & \multirow{17}{*}{ EPA $200.7 a$} & 0.050 & $\mathrm{C}$ \\
\hline Barium & & & & & 0.0007 & $\mathrm{C}$ \\
\hline Calcium & & & & & 0.023 & $\mathrm{C}$ \\
\hline Chromium & & & & & 0.008 & $\mathrm{C}$ \\
\hline Copper & & & & & 0.007 & $\mathrm{C}$ \\
\hline Iron & & & & & 0.006 & $\mathrm{C}$ \\
\hline Lead & & & & & 0.071 & $\mathrm{C}$ \\
\hline Magnesium & & & & & 0.030 & $\mathrm{C}$ \\
\hline Manganese & & & & & 0.002 & C \\
\hline Nickel & & & & & 0.049 & $\mathrm{C}$ \\
\hline Phosphorus & & & & & 0.121 & $\mathrm{C}$ \\
\hline Potassium & & & & & 1.21 & $\mathrm{C}$ \\
\hline Silicon & & & & & 0.034 & C \\
\hline Sodium & & & & & 0.018 & $\mathrm{C}$ \\
\hline Strontium & & & & & 0.001 & $\mathrm{C}$ \\
\hline Sulfur & & & & & 0.030 & C \\
\hline Zinc & & & & & 0.004 & $\mathrm{C}$ \\
\hline
\end{tabular}

*As of July 1993 
Table B-1. Continued.

Nutrients

\begin{tabular}{|c|c|c|c|c|c|c|}
\hline Analyte & Container & Preservative & $\begin{array}{c}\text { Holding } \\
\text { Time }\end{array}$ & $\begin{array}{l}\text { Analytical } \\
\text { Procedure }\end{array}$ & $\begin{array}{l}M D L^{*} \\
(m g / L)\end{array}$ & $\begin{array}{c}\text { Analysis } \\
\text { Suite }\end{array}$ \\
\hline Phosphorus-Total & \multirow{6}{*}{ Polyethylene } & \multirow{6}{*}{$\mathrm{H}_{2} \mathrm{SO}_{4}$, ice } & \multirow{3}{*}{14 days } & Calculated & 0.121 & $\mathrm{C}$ \\
\hline Orthophosphate & & & & EPA 365 & 0.009 & C \\
\hline Nitrate-Nitrogen & & & & EPA 300.0 & 0.02 & $\mathrm{C}, \mathrm{B}, \mathrm{E}$ \\
\hline Ammonia-Nitrogen & & & \multirow{3}{*}{48 hours } & EPA 350.3 & 0.07 & C \\
\hline Kjeldahl-Nitrogen & & & & EPA 351.4 & 0.03 & $\mathrm{C}$ \\
\hline Nitrite-Nitrogen & & & & EPA 354.1 & 0.002 & $\mathrm{C}$ \\
\hline
\end{tabular}

Inorganics-Nonmetals

\begin{tabular}{|c|c|c|c|c|c|c|}
\hline Analyte & Container & Preservative & $\begin{array}{c}\text { Holding } \\
\text { Time }\end{array}$ & $\begin{array}{l}\text { Analytical } \\
\text { Procedure }\end{array}$ & $\begin{array}{l}M D L^{*} \\
(m g / L)\end{array}$ & $\begin{array}{c}\text { Analysis } \\
\text { Suite }\end{array}$ \\
\hline Bicarbonate & \multirow{9}{*}{ Polyethylene } & \multirow{9}{*}{ Ice only } & \multirow{9}{*}{28 days } & Calculated & 3.0 & $\mathrm{C}$ \\
\hline Chloride & & & & EPA 300.0 & 1.0 & $\mathrm{C}$ \\
\hline Conductance & & & & EPA 120.1 & - & C \\
\hline Fluoride & & & & EPA 340.2 & 0.020 & $\mathrm{C}$ \\
\hline $\mathrm{pH}$ & & & & EPA 150.1 & - & $\mathrm{C}$ \\
\hline Sulfate & & & & EPA 300.0 & 5.0 & $\mathrm{C}$ \\
\hline Total hardness & & & & Calculated & 1.0 & $\mathrm{C}, \mathrm{E}$ \\
\hline Suspended solids & & & & EPA 160.1 & 3.0 & $\mathrm{C}, \mathrm{E}$ \\
\hline Dissolved solids & & & & EPA 160.1 & 10.0 & $\mathrm{C}, \mathrm{E}$ \\
\hline
\end{tabular}

Pesticides-Gas chromatograph

\begin{tabular}{|c|c|c|c|c|c|c|}
\hline Analyte & Container & Preservative & $\begin{array}{c}\text { Holding } \\
\text { Time }\end{array}$ & $\begin{array}{l}\text { Analytical } \\
\text { Procedure }\end{array}$ & $\begin{array}{l}M D L^{*} \\
(\mu g / L)\end{array}$ & $\begin{array}{c}\text { Analysis } \\
\text { Suite }\end{array}$ \\
\hline Butylate & \multirow{17}{*}{ Amber glass } & \multirow{17}{*}{ Ice only } & \multirow{17}{*}{7 days } & \multirow{17}{*}{ EPA $507 \& 508$} & 0.40 & \multirow{17}{*}{ C } \\
\hline Trifluralin & & & & & 0.01 & \\
\hline Atrazine & & & & & 0.30 & \\
\hline Metribuzin & & & & & 0.01 & \\
\hline Alachlor & & & & & 0.03 & \\
\hline Linuron & & & & & 0.10 & \\
\hline Metolachlor & & & & & 0.05 & \\
\hline Pendimethalin & & & & & 0.02 & \\
\hline Simazine & & & & & 0.30 & \\
\hline Malathion & & & & & 0.05 & \\
\hline Chlorpyrifos & & & & & 0.007 & \\
\hline Endosulfan I & & & & & 0.02 & \\
\hline Endosulfan II & & & & & 0.02 & \\
\hline \begin{tabular}{|l} 
Permethrin \\
\end{tabular} & & & & & 0.10 & \\
\hline Diazinon & & & & & 0.10 & \\
\hline Chlorothalonil & & & & & 0.01 & \\
\hline Cyanazine & & & & & 0.50 & \\
\hline
\end{tabular}

*As of July 1993 
Table B-1. Continued.

Pesticides-Enzyme-linked immunosorbent assay

\begin{tabular}{|c|c|c|c|c|c|c|}
\hline Analyte & Container & Preservative & $\begin{array}{l}\text { Holding } \\
\text { Time }\end{array}$ & $\begin{array}{l}\text { Analytical } \\
\text { Procedure }\end{array}$ & $\begin{array}{c}M D L \\
(\mu g / L)\end{array}$ & $\begin{array}{c}\text { Analysis } \\
\text { Suite }\end{array}$ \\
\hline Alachlor & \multirow{5}{*}{ Amber glass } & \multirow{5}{*}{ Ice only } & \multirow{5}{*}{7 days } & \multirow{5}{*}{$\begin{array}{l}\text { KGS water- } \\
\text { quality lab }\end{array}$} & 0.06 & \multirow{4}{*}{$\mathrm{C}, \mathrm{B}, \mathrm{E}$} \\
\hline Metolachlor & & & & & 0.05 & \\
\hline Triazine & & & & & 0.06 & \\
\hline Carbofuran & & & & & 0.07 & \\
\hline $2,4-D$ & & & & & 0.90 & $\mathrm{C}$ \\
\hline
\end{tabular}

Bacteria

\begin{tabular}{|c|c|c|c|c|c|c|}
\hline Analyte & Container & Preservative & $\begin{array}{c}\text { Holding } \\
\text { Time }\end{array}$ & $\begin{array}{l}\text { Analytical } \\
\text { Procedure }\end{array}$ & $\begin{array}{c}M D L \\
\text { (count) }\end{array}$ & $\begin{array}{c}\text { Analysis } \\
\text { Suite }\end{array}$ \\
\hline Total coli & \multirow{3}{*}{ Nalgene } & \multirow{3}{*}{ Ice only } & \multirow{3}{*}{6 hours } & SM 17 9222B & 1 & \multirow{3}{*}{$\mathrm{T}$} \\
\hline Fecal coli & & & & SM 17 9222D & 1 & \\
\hline Fecal strep & & & & SM $179230 B$ & 1 & \\
\hline
\end{tabular}




\section{ApPendix C:}

Analyses of Precipitation and Miscellaneous Quality-Assurance and Quality-Control Samples 
Precipitation Samples

\begin{tabular}{|c|c|c|c|c|c|c|c|c|}
\hline $\begin{array}{l}\text { Sample } \\
\text { Number }\end{array}$ & Date & $\begin{array}{l}\text { Time } \\
\text { (CST) }\end{array}$ & $\begin{array}{c}\text { Total ELISA } \\
\text { Triazines } \\
(\mu g / L)\end{array}$ & $\begin{array}{c}\text { Total GC } \\
\text { Atrazine } \\
(\mu \mathrm{g} / \mathrm{L})\end{array}$ & $\begin{array}{c}\text { Total ELISA } \\
\text { Carbofuran } \\
(\mu g / L)\end{array}$ & $\begin{array}{c}\text { Total ELISA } \\
\text { Metolachlor } \\
(\mu \mathrm{g} / \mathrm{L})\end{array}$ & $\begin{array}{l}\text { Nitrate } \\
\text { (as N) } \\
(\mathrm{mg} / \mathrm{L})\end{array}$ & $\begin{array}{c}\text { Deployment } \\
\text { Duration }\end{array}$ \\
\hline RAIN0001 & Jun/4/1992 & $12: 35$ & $<0.06$ & & $<0.07$ & $<0.06$ & & 1:45 hrs. \\
\hline RAIN0002 & Jul/7/1992 & $13: 43$ & $<0.06$ & $<0.08$ & $<0.07$ & 0.18 & & 21 days \\
\hline RAIN0003 & May/19/1992 & $8: 55$ & 0.68 & & $<0.07$ & 0.81 & & $17 \mathrm{hrs}$. \\
\hline RAIN0004 & Jun/1/1993 & $16: 43$ & 0.93 & 0.55 & $<0.07$ & 0.35 & & 12 days \\
\hline RAIN0005 & Jul/1/1993 & $8: 05$ & $<0.06$ & & $<0.07$ & 0.2 & 0.28 & 30 days \\
\hline RAIN0006 & Mar/28/1994 & $11: 40$ & $<0.07$ & & $<0.08$ & $<0.08$ & 0.271 & $21: 30$ hrs. \\
\hline RAIN0007 & Jun/2/1994 & $11: 56$ & $<0.07$ & & $<0.08$ & $<0.08$ & 0.926 & 1:15 hrs. \\
\hline
\end{tabular}

Miscellaneous Samples

\begin{tabular}{|c|c|c|c|c|c|c|c|}
\hline $\begin{array}{c}\text { Sample } \\
\text { Number }\end{array}$ & Date & $\begin{array}{c}\text { Time } \\
(\mathrm{CST})\end{array}$ & $\begin{array}{c}\text { Total ELISA } \\
\text { Triazines } \\
(\mu \mathrm{g} / \mathrm{L})\end{array}$ & $\begin{array}{c}\text { Total GC } \\
\text { Atrazine } \\
(\mu \mathrm{g} / \mathrm{L})\end{array}$ & $\begin{array}{c}\text { Total ELISA } \\
\text { Carbofuran } \\
(\mu \mathrm{g} / \mathrm{L})\end{array}$ & $\begin{array}{c}\text { Total ELISA } \\
\text { Metolachlor } \\
(\mu \mathrm{g} / \mathrm{L})\end{array}$ & $\begin{array}{c}\text { Nitrate } \\
(\text { as } N) \\
(\mathrm{mg} / \mathrm{L})\end{array}$ \\
\hline CAWW0001 & Apr/28/1994 & $7: 36$ & 1.4 & & $<0.08$ & 0.33 & 2.76 \\
\hline CAWW0002 & Apr/28/1994 & $7: 36$ & 1.1 & $<0.1$ & $<0.08$ & 0.17 & 2.69 \\
\hline LDWW0001 & $\mathrm{Jun} / 26 / 1991$ & $7: 23$ & 2.01 & & & & 6.0 \\
\hline MHWW0001 Jun/24/1993 & $9: 00$ & 3.2 & & $<0.06$ & 0.28 & 3.14 \\
\hline MMWW0001 Jul/15/1993 & $10: 50$ & $<0.06$ & & $<0.07$ & $<0.06$ & 0.77 \\
\hline
\end{tabular}


Quality-Assurance/Quality-Control Samples

\begin{tabular}{|c|c|c|c|c|c|c|c|}
\hline $\begin{array}{l}\text { Sample } \\
\text { Number }\end{array}$ & Date & $\begin{array}{c}\text { Time } \\
\text { (CST) }\end{array}$ & $\begin{array}{c}\text { Total ELISA } \\
\text { Triazines } \\
(\mu \mathrm{g} / \mathrm{L})\end{array}$ & $\begin{array}{c}\text { Total GC } \\
\text { Atrazine } \\
(\mu g / L)\end{array}$ & $\begin{array}{c}\text { Total ELISA } \\
\text { Carbofuran } \\
(\mu g / L)\end{array}$ & $\begin{array}{c}\text { Total ELISA } \\
\text { Metolachlor } \\
(\mu \mathrm{g} / \mathrm{L})\end{array}$ & $\begin{array}{l}\text { Nitrate } \\
\text { (as N) } \\
\text { (mg/L) }\end{array}$ \\
\hline LPDP0090 & May/12/1994 & $10: 40$ & 1.3 & & $<0.08$ & 0.44 & 5.29 \\
\hline PGDP0306 & Dec/8/1993 & $9: 30$ & 1.2 & & $<0.07$ & $<0.06$ & 7.45 \\
\hline PGDP0342 & Feb/2/1994 & $12: 10$ & $<0.07$ & & & & 7.32 \\
\hline PGDP0344 & Mar/1/1994 & $11: 00$ & 0.72 & & $<0.08$ & $<0.08$ & 6.94 \\
\hline PGDP0346 & Mar/28/1994 & $15: 57$ & 2.1 & & $<0.08$ & 0.28 & 4.97 \\
\hline PGDP0385 & Apr/7/1994 & $14: 00$ & 1.9 & & & & 6.17 \\
\hline PGDP0392 & Apr/13/1994 & $6: 15$ & 2.2 & & $<0.08$ & 0.24 & 5.58 \\
\hline PGDP0412 & Apr/27/1994 & $10: 00$ & 1.8 & & $<0.08$ & 0.42 & 3.95 \\
\hline PGDP0463 & Jun/1/1994 & $12: 00$ & 1.0 & & $<0.08$ & $<0.08$ & 4.2 \\
\hline PGDP0532 & Jul/7/1994 & $7: 10$ & 1.1 & & & & \\
\hline PGDP0539 & Aug/16/1994 & $10: 00$ & 0.72 & & & $<0.08$ & 4.31 \\
\hline PGEB0215 & May/4/1993 & $13: 55$ & & $<0.23$ & & & \\
\hline PGEB0159 & Mar/5/1993 & $10: 00$ & & $<0.018$ & & & \\
\hline PGEB0065 & Oct/6/1993 & $12: 50$ & & $<0.16$ & & & \\
\hline PGEB0343 & Feb/22/1994 & $11: 20$ & $<0.07$ & $<0.19$ & $<0.08$ & $<0.08$ & $<0.1$ \\
\hline PGEB2901 & Mar/2/1994 & $10: 00$ & $<0.07$ & & & & $<0.1$ \\
\hline PGEB3701 & Mar/2/1994 & $10: 00$ & $<0.07$ & & & & $<0.1$ \\
\hline LPEB3702 & Mar/2/1994 & $14: 00$ & $<0.07$ & & & & $<0.1$ \\
\hline PGEB0364 & Mar/28/1994 & $13: 00$ & $<0.07$ & & $<0.08$ & $<0.08$ & $<0.1$ \\
\hline PGEB0412 & Apr/27/1994 & $10: 00$ & $<0.06$ & & $<0.08$ & $<0.08$ & $<0.1$ \\
\hline PGEB0532 & Jul/7/1994 & $7: 10$ & $<0.07$ & & & & $<0.1$ \\
\hline FIBK0002 & Apr/29/1992 & $7: 33$ & $<0.06$ & $<0.021$ & $<0.07$ & $<0.04$ & \\
\hline FIBK0306 & Dec/8/1993 & $9: 30$ & $<0.06$ & & $<0.07$ & $<0.06$ & $<0.1$ \\
\hline FIBK0342 & Feb/02/1994 & $12: 10$ & $<0.07$ & & & & $<0.1$ \\
\hline
\end{tabular}

\section{Sample Number Explanations}

\section{RAIN-Precipitation sample}

CAWW-City of Adairville Water Works, Russell Law Oper.

MHWW-Water well; see ID number 17174, Appendix E

MMWW-Water well; see ID number 17155, Appendix E

LDWW-Water well; see ID number 11385, Appendix E

LPDP_Duplicate of Leslie Page karst window sample

PGDP_Duplicates of Pleasant Grove Spring samples

PGEB_Equipment blank collected at Pleasant Grove Spring

LPEB-Equipment blank collected at Leslie Page karst window

FIBK-Field blank 


\section{ApPENDIX D:}

Summary of Ground-Water Dye Traces in the Pleasant Grove Spring Basin Study Area 
Adairville Quadrangle

Spring Name: Unknown (probably Masons Spring)

\begin{tabular}{|l|l|l|c|c|c|c|c|}
\hline ID Number & Formation/Member & Spring Type & Receiving Water Body & River Basin & Latitude & Longitude & Elevation \\
\hline 13793 & St. Louis & Gravity & Little Whippoorwill Ck. & LCR & 364325.0 & 865058.0 & 530.0 \\
\hline $\begin{array}{l}\text { Comments: Detected in Little Whippoorwill Creek at Kentucky Highway } 663 \text { bridge, approximately } 1.5 \text { mi downstream of Masons Spring, the largest } \\
\text { spring known between Hobsons Spring and Kentucky Highway 663. }\end{array}$ \\
\hline Researcher & Injection Point Name & Dye Used & Dye Injection & Bug Recovery & Latitude & Longitude & Elevation \\
\hline JCC DK & Tadpole estavelle & Fluorescein & Jun/13/1991 & Jun/19/1991 & 364455.0 & 865157.0 & 585.0 \\
\hline
\end{tabular}

Dennis Quadrangle

Spring Name: Hobsons

\begin{tabular}{|l|l|l|c|c|c|c|c|}
\hline ID Number & Formation/Member & Spring Type & Receiving Water Body & River Basin & Latitude & Longitude & Elevation \\
\hline 13161 & St. Louis & Rise pool & Little Whippoorwill Ck. & LCR & 364507.0 & 865123.0 \\
\hline Comments: About 2,000 ft northeast of intersection U.S. Highway 431 and Kentucky Highway 739. & 570.0 \\
\hline Researcher & Injection Point Name & Dye Used & Dye Injection & Bug Recovery & Latitude & Longitude & Elevation \\
\hline JCC CDG & McCaleb karst window & Tinopal CBS-X & Apr/24/1991 & Apr/30/1991 & 364705.0 & 865145.0 & 595.0 \\
\hline JCC DG & Scales karst window & Rhodamine WT & Feb/20/1991 & Mar/27/1991 & 364608.0 & 865130.0 & 585.0 \\
\hline JCC DK & Greenbriar Cave & Rhodamine WT & Jun/13/1991 & Jun/19/1991 & 364758.0 & 865111.0 & 620.0 \\
\hline JCC DK & Crawdad estavelle & Tinopal CBS-X & Jul/11/1991 & Aug/21/1991 & 364719.0 & 865231.0 & 615.0 \\
\hline JCC DK & Scales estavelle & Fluorescein & Jul/11/1991 & Jul/18/1991 & 364612.0 & 865158.0 & 585.0 \\
\hline DG RM & Unnamed sinkhole & Rhodamine WT & Sep/09/1992 & Sep/23/1992 & 364838.0 & 865231.5 & 655.0 \\
\hline
\end{tabular}


Dot Quadrangle

\begin{tabular}{|c|c|c|c|c|c|c|c|}
\hline ID Number & Formation/Member & Spring Type & Receiving Water Body & River Basin & Latitude & Longitude & Elevation \\
\hline 10795 & St. Louis & Rise pool & Pleasant Grove Creek & LCR & 364244.0 & 865419.0 & 510.0 \\
\hline \multicolumn{8}{|c|}{ Comments: Also called Dripping Spring. Perennial discharge from a bedrock cave at 1 to $200 \mathrm{ft}^{3} / \mathrm{s}$. } \\
\hline Researcher & Injection Point Name & Dye Used & Dye Injection & Bug Recovery & Latitude & Longitude & Elevation \\
\hline JCC DK & The Canyon & Direct Yellow 96 & Apr/18/1991 & Apr/23/1991 & 364451.0 & 865358.0 & 550.0 \\
\hline JCC DK & Delaney swallow hole & Rhodamine WT & Apr/18/1991 & Apr/23/1991 & 364425.0 & 865512.0 & 540.0 \\
\hline JCC DG & Kemper karst window & Direct Yellow 96 & Mar/21/1991 & Mar/27/1991 & 364322.0 & 865330.0 & 550.0 \\
\hline$J C C D G$ & Dotson karst window & Fluorescein & Mar/21/1991 & Mar/27/1991 & 364349.0 & 865441.0 & 535.0 \\
\hline JCC DK & Harper well & Tinopal CBS-X & Jun/13/1991 & Jun/19/1991 & 364554.0 & 865333.0 & 580.0 \\
\hline JCC JA & U. Pleasant Gr. Ck. (UPGC) & Rhodamine WT & Jan/16/1992 & Jan/23/1992 & 364535.0 & 865450.0 & 575.0 \\
\hline JCC & Poison Ivy karst window & Fluorescein & Jun/04/1992 & Jun/10/1992 & 364348.0 & 865242.0 & 580.0 \\
\hline DG & Harper karst window & Rhodamine WT & Apr/21/1992 & May/14/1992 & 364512.0 & 865402.5 & 595.0 \\
\hline JCC EF & Piper estavelle, UPGC & Rhodamine WT & Nov/25/1992 & Dec/16/1992 & 364535.0 & 865450.0 & 575.0 \\
\hline JCC DG & Headwaters, UPGC & Rhodamine WT & Jan/21/1993 & Feb/03/1993 & 364713.0 & 865508.0 & 595.0 \\
\hline JCC DG & Bob Miller sinkhole & Fluorescein & Jan/20/1993 & $\operatorname{Jan} / 28 / 1993$ & 364435.0 & 865245.0 & 585.0 \\
\hline JCC EF & Johnson swallow hole & Rhodamine WT & Mar/24/1993 & Apr/01/1993 & 364305.0 & 865444.0 & 520.0 \\
\hline JCC & Wheatfield estavelle & Fluorescein & Apr/22/1993 & May/05/1993 & 364435.0 & 865337.0 & 580.0 \\
\hline JCC & Gooch sinkhole & Rhodamine WT & Jan/27/1994 & Feb/02/1994 & 364537.0 & 865238.0 & 610.0 \\
\hline JCC & Marvin Dotson sinkhole & Fluorescein & Mar/27/1994 & Mar/29/1994 & 364332.0 & 865420.0 & 565.0 \\
\hline
\end{tabular}

\section{Spring Name: Dotson Spring}

\begin{tabular}{|l|l|l|c|c|c|c|c|}
\hline ID Number & Formation/Member & Spring Type & Receiving Water Body & River Basin & Latitude & Longitude & Elevation \\
\hline 13686 & St. Louis & Rise pool & Pleasant Grove Creek & \multicolumn{2}{|c|}{ LCR } & 364218.0 & 865438.0 \\
\hline Comments: On east bank of Pleasant Grove Creek, west of Stovall Road, and approximately 0.75 mi downstream of Pleasant Grove Spring. \\
\hline \multicolumn{1}{|c|}{ Researcher } & Injection Point Name & Dye Used & Dye Injection & Bug Recovery & Latitude & Longitude & Elevation \\
\hline JCC & Timmie karst window & Direct Yellow 96 & Feb/19/1992 & Feb/25/1992 & 364219.0 & 865418.0 & 505.0 \\
\hline JCC DG & Travis sinkhole & Fluorescein & Dec/02/1992 & Dec/16/1992 & 364244.0 & 865234.0 & 560.0 \\
\hline
\end{tabular}


Spring Name: Campbell blue hole

\begin{tabular}{|l|l|c|c|c|c|c|c|}
\hline ID Number & Formation/Member & Spring Type & Receiving Water Body & River Basin & Latitude & Longitude & Elevation \\
\hline 13800 & St. Louis & Rise pool & Pleasant Grove Creek & LCR & 364202.0 & 865507.0 & 495.0 \\
\hline Comments: Located 1,000 ft east of Kentucky Highway 96 and 100 ft west of Pleasant Grove Creek. & & & \\
\hline Researcher & Injection Point Name & Dye Used & Dye Injection & Bug Recovery & Latitude & Longitude & Elevation \\
\hline JCC DK & Richarson karst window & Direct Yellow 96 & Jun/13/1991 & Jun/19/1991 & 364207.0 & 865558.0 & 535.0 \\
\hline JCC JA & Trailer karst window & Direct Yellow 96 & Jan/16/1992 & Jan/23/1992 & 364217.0 & 865514.0 & 540.0 \\
\hline
\end{tabular}

\section{Spring Name: Claude Blick}

\begin{tabular}{|l|l|c|c|c|c|c|c|}
\hline ID Number & Formation/Member & Spring Type & Receiving Water Body & River Basin & Latitude & Longitude & Elevation \\
\hline 13802 & St. Louis & Gravity & Whippoorwill Creek & LCR & 364253.0 & 865735.0 & 495.0 \\
\hline Comments: Located & 200 ft west of Kentucky Highway 1041, on east bank of Whippoorwill Creek. & \multicolumn{1}{|c|}{} \\
\hline Researcher & Injection Point Name & Dye Used & Dye Injection & Bug Recovery & Latitude & Longitude & Elevation \\
\hline JCC DK & Roaring well Cave & Rhodamine WT & Jul/11/1991 & Jul/18/1991 & 364258.0 & 865629.0 & 540.0 \\
\hline
\end{tabular}

Spring Name: Unknown (probably unnamed spring on Pleasant Grove (Creek)

\begin{tabular}{|l|l|l|c|c|c|c|c|}
\hline ID Number & Formation/Member & Spring Type & Receiving Water Body & River Basin & Latitude & Longitude & Elevation \\
\hline 13161 & St. Louis & Gravity & Pleasant Grove Creek & LCR & 364217.0 & 865450.0 & 505.0 \\
\hline $\begin{array}{l}\text { Comments: Detected in Pleasant Grove Creek at Mortimer Road bridge, approximately 1/8 mile downstream of an unnamed spring on the west bank of Pleasant Grove } \\
\text { Creek, less than 100 feet west of an abandoned house. The spring is the largest known on the west bank between Pleasant Grove Spring and Mortimer Road. }\end{array}$ \\
\hline Researcher & Injection Point Name & Dye Used & Dye Injection & Bug Recovery & Latitude & Longitude & Elevation \\
\hline JCC EF & Rodgers sinkhole & Fluorescein & Mar/24/1993 & Apr/01/1993 & 364255.0 & 865509.0 & 550.0 \\
\hline
\end{tabular}

\section{Russellville Quadrangle}

Spring Name: Steve Blick

\begin{tabular}{|l|l|l|c|c|c|c|c|}
\hline ID Number & Formation/Member & Spring Type & Receiving Water Body & River Basin & Latitude & Longitude & Elevation \\
\hline 13805 & Ste. Genevieve & Gravity & Whippoorwill Creek & LCR & 364508.0 & 865859.0 & 530 \\
\hline $\begin{array}{l}\text { Comments: Located on east bank of Whippoorwill Creek, northwest of intersection of Kentucky Highway 1309, and Kentucky Highway } 775 \text {, and about 400 ft. west } \\
\text { of Kentucky Highway 1309. }\end{array}$ \\
\hline Researcher & Injection Point Name & Dye Used & Dye Injection & Bug Recovery & Latitude & Longitude & Elevation \\
\hline JCC EF & King Cave & Rhodamine WT & Mar/04/1993 & Mar/23/1993 & 364436.0 & 865715.0 & 565 \\
\hline
\end{tabular}


Spring Name: Dawson

\begin{tabular}{|c|c|c|c|c|c|c|c|}
\hline ID Number & Formation/Member & Spring Type & Receiving Water Body & River Basin & Latitude & Longitude & Elevation \\
\hline 13806 & Ste. Genevieve & Gravity & Whippoorwill Creek & LCR & 364614.0 & 865814.0 & 550 \\
\hline \multicolumn{8}{|c|}{ Comments: Located approximately 2,000 ft. west of Kentucky Highway 1041 on east bank of Whippoorwill Creek. } \\
\hline Researcher & Injection Point Name & Dye Used & Dye Injection & Bug Recovery & Latitude & Longitude & Elevation \\
\hline JCC DK & Hickory Hill Karst W. & Fluorescein & Apr/18/1991 & Apr/23/1991 & 364528.0 & 865610.0 & 575 \\
\hline JCC DK & Drinking Cup Cave & Direct Yellow 96 & $\mathrm{Jul} / 11 / 1991$ & Jul/18/1991 & 364630.0 & 865647.0 & 585 \\
\hline $\mathrm{JCC}$ DH & Miles karst window & Tinopal CBS-X & Mar/26/1992 & Apr/01/1992 & 364606.0 & 865602.0 & 590 \\
\hline DG & Shackelford sinkhole & Tinopal CBS-X & Apr/21/1992 & Apr/30/1992 & 364619.0 & 865500.0 & 585 \\
\hline
\end{tabular}

\section{Spring Name: Spring View}

Spring Name: Spring View
\begin{tabular}{|l|l|l|c|c|c|c|c|}
\hline ID Number & Formation/Member & Spring Type & Receiving Water Body & River Basin & Latitude & Longitude & Elevation \\
\hline 13809 & Ste. Genevieve & Rise Pool & Dry Fork of Whippoorwill Ck. & LCR & 364746.0 & 865830.0 & \\
\hline Comments: Located 400 ft south of U.S. Highway 79 , and flows into Dry Fork. & & & & \\
\hline \multicolumn{1}{|l|}{ Researcher } & Injection Point Name & Dye Used & Dye Injection & Bug Recovery & Latitude & Longitude & Elevation \\
\hline JCC JA & Toon Swallow Hole & Direct Yellow 96 & Jan/16/1992 & Jan/23/1992 & 364758.0 & 865658.0 & 585 \\
\hline JCC JA & Wilkins karst window & Fluorescein & Jan/16/1992 & Jan/23/1992 & 364814.0 & 865415.0 & 615 \\
\hline JCC & Golf Course swallow hole & Rhodamine WT & Feb/19/1992 & Feb/25/1992 & 364855.0 & 865305.0 & 645 \\
\hline JCC & Sansom estavelle & Tinopal CBS-X & Feb/19/1992 & Feb/25/1992 & 364827.0 & 865325.0 & 635 \\
\hline
\end{tabular}

\section{Spring Name: Thad Flowers blue hole}

Spring Name: Thad Flowers blue hole
\begin{tabular}{|l|l|l|c|c|c|c|c|}
\hline ID Number & Formation/Member & Spring Type & Receiving Water Body & River Basin & Latitude & Longitude & Elevation \\
\hline 13950 & Ste. Genevieve & Rise Pool & Upper Pleasant Grove Creek & LCR & 364635.0 & 865348.0 & 600 \\
\hline Comments: An estevelle located 2,000 ft east of Kentucky Highway 96 in a grove of trees. & & & & \\
\hline Researcher & Injection Point Name & Dye Used & Dye Injection & Bug Recovery & Latitude & Longitude & Elevation \\
\hline JCC & Hindman sinkhole & Fluorescein & Feb/16/1993 & Mar/03/1993 & 364653.0 & 865343.0 & 610 \\
\hline
\end{tabular}




\section{ApPendix E:}

Inventory of Water Wells in the Pleasant Grove Spring Basin 
Static Water Levels Measured Between June 1 and September 13, 1993

\begin{tabular}{|c|c|c|c|c|c|}
\hline Well ID Number & Latitude & Longitude & $\begin{array}{c}\text { Total Depth } \\
(f t)\end{array}$ & $\begin{array}{c}\text { Elevation } \\
(\mathrm{ft})\end{array}$ & $\begin{array}{c}\text { Static Water Level } \\
(f t)\end{array}$ \\
\hline 11385 & 364628 & 865746 & 100.0 & 590 & \\
\hline 11485 & 364220 & 865435 & 37.0 & 530 & \\
\hline 11486 & 364225 & 865432 & 92.2 & 530 & 23.5 \\
\hline 11487 & 364225 & 865257 & 135.0 & 580 & 60.0 \\
\hline 11488 & 364230 & 865250 & 165.0 & 580 & 70.0 \\
\hline 11489 & 364313 & 865330 & 17.7 & 560 & 17.7 \\
\hline 11490 & 364315 & 865325 & & 570 & \\
\hline 11491 & 364318 & 865350 & 76.6 & 580 & 61.8 \\
\hline 11492 & 364328 & 865405 & 96.9 & 575 & 59.6 \\
\hline 11493 & 364340 & 865445 & 91.5 & 585 & 71.5 \\
\hline 11495 & 364222 & 865409 & & 540 & \\
\hline 11496 & 364407 & 865432 & & 575 & \\
\hline 11497 & 364433 & 865520 & & 580 & \\
\hline 11498 & 364428 & 865430 & 80.0 & 590 & 60.0 \\
\hline 11499 & 364452 & 865408 & 95.5 & 600 & 72.5 \\
\hline 11500 & 364430 & 865238 & 46.2 & 620 & 22.2 \\
\hline 17127 & 364458 & 865353 & 35.0 & 610 & 25.0 \\
\hline 17128 & 364445 & 865317 & 65.7 & 600 & 49.2 \\
\hline 17129 & 364458 & 865402 & & 590 & \\
\hline 17151 & 364515 & 865315 & & 600 & \\
\hline 17152 & 364450 & 865250 & 100.1 & 605 & 54.3 \\
\hline 17153 & 364502 & 865236 & 98.0 & 620 & 80.0 \\
\hline 17154 & 364452 & 865232 & & 620 & \\
\hline 17155 & 364500 & 865238 & 94.5 & 620 & 45.0 \\
\hline 17156 & 364508 & 865240 & 31.1 & 620 & 26.1 \\
\hline 17157 & 364432 & 865425 & & 610 & \\
\hline 17158 & 364440 & 865228 & 84.2 & 620 & 60.0 \\
\hline 17159 & 364456 & 865228 & & 620 & \\
\hline 17160 & 364448 & 865235 & 33.7 & 615 & 31.8 \\
\hline 17161 & 364330 & 865230 & & 620 & \\
\hline 17162 & 364328 & 865215 & & 600 & \\
\hline 17163 & 364305 & 865200 & & 610 & \\
\hline 17164 & 364318 & 865335 & & 600 & \\
\hline 17165 & 364455 & 865328 & 63.0 & 590 & 30.0 \\
\hline 17166 & 364450 & 865420 & & 612 & \\
\hline 17167 & 364525 & 865425 & & 610 & \\
\hline 17168 & 364520 & 865320 & 75.0 & 610 & 55.0 \\
\hline 17169 & 364250 & 864450 & 65.0 & 560 & 60.0 \\
\hline 17170 & 364320 & 865340 & 69.5 & 560 & 36.7 \\
\hline 17171 & 364553 & 865345 & & 640 & \\
\hline 17172 & 364553 & 865315 & 66.0 & 630 & 55.0 \\
\hline 17173 & 364535 & 865255 & & 640 & \\
\hline 17174 & 364530 & 865250 & 65.0 & 620 & \\
\hline 17175 & 364603 & 865410 & 64.6 & 605 & 23.0 \\
\hline 17176 & 364608 & 865410 & & 590 & 8.5 \\
\hline 17177 & 364720 & 865455 & 73.8 & 605 & 8.5 \\
\hline 17178 & 364630 & 865400 & 37.5 & 610 & 24.6 \\
\hline 17179 & 364718 & 865425 & 104.6 & 640 & 29.6 \\
\hline
\end{tabular}


Static Water Levels (Continued)

\begin{tabular}{|c|c|c|c|c|c|}
\hline 17180 & 364715 & 865423 & 29.2 & 620 & 9.2 \\
\hline 17181 & 364740 & 865345 & 135.0 & 650 & \\
\hline 17182 & 364715 & 865345 & & 645 & \\
\hline 17183 & 364700 & 865445 & & 600 & \\
\hline 17184 & 364738 & 865340 & & 650 & \\
\hline 17185 & 364738 & 865338 & & 650 & \\
\hline 17186 & 364800 & 865400 & & 640 & \\
\hline 17187 & 364740 & 865305 & & 650 & \\
\hline 17188 & 364756 & 865228 & 87.1 & 640 & 22.2 \\
\hline 17189 & 364638 & 865258 & 90.0 & 640 & 50.0 \\
\hline 17190 & 364508 & 865220 & 42.3 & 620 & 33.3 \\
\hline 17191 & 364402 & 865228 & 64.0 & 600 & 30.0 \\
\hline 17192 & 364510 & 865225 & & 610 & \\
\hline 17193 & 364456 & 865215 & & 600 & \\
\hline 17194 & 364455 & 865215 & 44.0 & 620 & \\
\hline 17195 & 364550 & 865154 & & 610 & \\
\hline 17196 & 364615 & 865103 & & 600 & \\
\hline 17197 & 364730 & 865222 & & 625 & \\
\hline 17198 & 364722 & 865238 & 87.8 & 630 & 31.0 \\
\hline 17199 & 364548 & 865156 & & 630 & \\
\hline 17200 & 364450 & 865138 & & 600 & \\
\hline 17201 & 364404 & 865128 & 121.3 & 590 & 52.5 \\
\hline 17202 & 364447 & 865127 & 36.0 & 587 & 30.4 \\
\hline 17203 & 364412 & 865131 & & 595 & \\
\hline 17204 & 364250 & 865605 & & 600 & 60.0 \\
\hline 17205 & 364250 & 865415 & & 550 & \\
\hline 17206 & 364307 & 865504 & & 570 & \\
\hline 17207 & 364314 & 865440 & 90.0 & 560 & \\
\hline 17208 & 364308 & 865442 & & 540 & \\
\hline 17209 & 364326 & 865435 & 85.0 & 580 & 75.0 \\
\hline 17210 & 364402 & 865504 & 75.0 & 560 & 49.0 \\
\hline 17211 & 364330 & 865549 & 60.0 & 590 & 40.0 \\
\hline 17212 & 364402 & 865639 & 70.0 & 598 & 50.0 \\
\hline 17213 & 364407 & 865640 & 57.6 & 570 & 27.3 \\
\hline 17214 & 364526 & 865547 & 80.0 & 610 & 70.0 \\
\hline 17215 & 364550 & 865558 & & 600 & \\
\hline 17216 & 364740 & 865510 & & 620 & \\
\hline 17217 & 364650 & 865202 & & 640 & \\
\hline 17218 & 364806 & 865415 & & 640 & \\
\hline 17219 & 364803 & 865409 & 90.8 & 635 & 12.5 \\
\hline 17220 & 364719 & 865404 & 76.3 & 630 & 26.3 \\
\hline 17221 & 364508 & 865143 & 79.3 & 620 & 46.0 \\
\hline 17222 & 364432 & 865202 & & 620 & \\
\hline 17223 & 364510 & 865245 & & 620 & \\
\hline 17224 & 364426 & 865557 & & 590 & \\
\hline 17225 & 364352 & 865434 & & 600 & \\
\hline 17226 & 364549 & 865407 & 140.0 & 620 & 2.0 \\
\hline 17227 & 364643 & 865427 & 35.7 & 610 & 29.0 \\
\hline 17228 & 364635 & 865424 & & 600 & \\
\hline 17229 & 364309 & 865450 & 48.3 & 550 & 41.8 \\
\hline
\end{tabular}


Static Water Levels (Continued)

\begin{tabular}{|l|l|l|l|l|l|}
\hline 17230 & 364552 & 865322 & & 630 & \\
\hline 17231 & 364617 & 865457 & & 615 & \\
\hline 17232 & 364616 & 865502 & & 615 & \\
\hline 17233 & 364615 & 865457 & & 615 & \\
\hline 17234 & 364514 & 865144 & & 620 & \\
\hline 17235 & 364420 & 865639 & & 575 & \\
\hline 17236 & 364306 & 865553 & & 610 & \\
\hline 17237 & 364830 & 865548 & 22.4 & 610 & 11.3 \\
\hline 17238 & 364427 & 865630 & 85.3 & 580 & 50.0 \\
\hline 17239 & 364827 & 865551 & & 640 & \\
\hline 17240 & 364827 & 865553 & & 630 & 46.0 \\
\hline 17241 & 364830 & 865550 & 45.8 & 630 & 33.9 \\
\hline 17242 & 364814 & 865324 & & 640 & 39.2 \\
\hline
\end{tabular}


Appendix F:

Field Water-Quality Measurements and Descriptive Statistics for the Pleasant Grove Spring Drainage Basin 
Pleasant Grove Spring, August 1990-September 1991

\begin{tabular}{|c|c|c|c|c|c|}
\hline $\begin{array}{c}\text { Sample } \\
\text { Number }\end{array}$ & Date & Time (CST) & Field $\mathrm{pH}$ & $\begin{array}{c}\text { Field Specific } \\
\text { Conductance } \\
\left(\begin{array}{l}\left.\text { at } 25^{\circ} \mathrm{C}\right) \\
(\mu \mathrm{S})\end{array}\right.\end{array}$ & $\begin{array}{c}\text { Water } \\
\text { Temperature } \\
\left({ }^{\circ} \mathrm{C}\right)\end{array}$ \\
\hline PGSP0001 & Aug/02/1990 & $11: 15$ & 6.49 & 493 & 14.6 \\
\hline PGSP0002 & Feb/28/1991 & $9: 55$ & 5.90 & 349 & 12.2 \\
\hline PGSP0003 & May/01/1991 & $10: 10$ & 6.50 & 418 & 14.4 \\
\hline PGSP0004 & May/22/1991 & $11: 30$ & 6.38 & 390 & 15.2 \\
\hline PGSP0005 & Jun/26/1991 & $9: 42$ & 6.19 & 326 & 15.3 \\
\hline PGSP0006 & Jul/25/1991 & $10: 15$ & 6.54 & 423 & 15.1 \\
\hline PGSP0007 & Aug/29/1991 & $12: 30$ & 6.10 & 356 & 15.1 \\
\hline PGSP0008 & Sep/24/1991 & $9: 30$ & 6.60 & 422 & 14.6 \\
\hline \hline \multicolumn{7}{|c|}{ Average* } & 6.34 & 397 & 14.6 \\
\hline \multicolumn{7}{|c|}{ Maximum } & 6.60 & 493 & 15.3 \\
\hline Minimum & 5.90 & 326 & 12.2 \\
\hline Stand. Dev. & 0.25 & 53.5 & 1.0 \\
\hline \hline Coef. Var. & 0.04 & 0.1 & 0.1 \\
\hline
\end{tabular}

Spring Valley karst window, August 1990-September 1991

\begin{tabular}{|c|c|c|c|c|c|}
\hline $\begin{array}{l}\text { Sample } \\
\text { Number }\end{array}$ & Date & Time (CST) & Field $\mathrm{pH}$ & $\begin{array}{c}\text { Field Specific } \\
\text { Conductance } \\
\left(\text { at } 25^{\circ} \mathrm{C}\right) \\
(\mu S)\end{array}$ & $\begin{array}{c}\text { Water } \\
\text { Temperature } \\
\left({ }^{\circ} \mathrm{C}\right)\end{array}$ \\
\hline SVKW0001 & Aug/02/1990 & 10:00 & 6.32 & 478 & 14.3 \\
\hline SVKW0002 & Feb/28/1991 & $11: 00$ & 6.75 & 349 & 12.0 \\
\hline SVKW0003 & May/22/1991 & $12: 17$ & 6.42 & 384 & 14.9 \\
\hline SVKW0004 & Jun/26/1991 & $11: 00$ & 6.50 & 331 & 15.2 \\
\hline SVKW0005 & Jul/25/1991 & $9: 30$ & 6.60 & 424 & 14.8 \\
\hline SVKW0006 & Aug/29/1991 & $11: 35$ & 6.35 & 349 & 14.7 \\
\hline SVKW0007 & Sep/24/1991 & $8: 40$ & 6.60 & 411 & 14.4 \\
\hline & & Average* $^{*}$ & $\overline{6.51}$ & $\overline{389}$ & $\overline{14.3}$ \\
\hline & & Maximum & 6.75 & 478 & 15.2 \\
\hline & & Minimum & 6.32 & 331 & 12.0 \\
\hline & & Stand. Dev. & 0.15 & 52.0 & 1.1 \\
\hline & & Coef. Var. & $\overline{0.02}$ & $\overline{0.1}$ & $\overline{0.1}$ \\
\hline
\end{tabular}

*These statistics are presented as a descriptive summary of the table. The effects of aliasing and variable sampling intervals may significantly affect the validity of averages presented as representative of ground-water quality in the basin. No data means an analysis was not performed. 
The Canyon karst window, August 1990-September 1991

\begin{tabular}{|c|c|c|c|c|c|}
\hline $\begin{array}{l}\text { Sample } \\
\text { Number }\end{array}$ & Date & Time (CST) & Field $\mathrm{pH}$ & $\begin{array}{c}\text { Field Specific } \\
\text { Conductance } \\
\left(\text { at } 25^{\circ} \mathrm{C}\right) \\
(\mu S)\end{array}$ & $\begin{array}{c}\text { Water } \\
\text { Temperature } \\
\left({ }^{\circ} \mathrm{C}\right)\end{array}$ \\
\hline TCKW0001 & Aug/02/1990 & 9:00 & 5.97 & 370 & $\overline{14.1}$ \\
\hline TCKW0002 & May/01/1991 & $8: 45$ & 6.30 & 408 & 13.6 \\
\hline TCKW0003 & May/22/1991 & 9:30 & 6.40 & 386 & 14.4 \\
\hline TCKW0004 & Jun/26/1991 & $7: 45$ & 6.52 & 349 & 14.4 \\
\hline TCKW0005 & Jul/25/1991 & $8: 24$ & 6.30 & 405 & 14.4 \\
\hline TCKW0006 & Aug/29/1991 & $10: 45$ & 6.38 & 335 & 14.5 \\
\hline TCKW0007 & Sep/24/1991 & $7: 40$ & 6.42 & 400 & 14.4 \\
\hline & & Average* $^{*}$ & 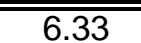 & $\overline{\overline{379}}$ & 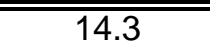 \\
\hline & & Maximum & 6.52 & 408 & 14.5 \\
\hline & & Minimum & 5.97 & 335 & 13.6 \\
\hline & & Stand. Dev. & 0.17 & 28.6 & 0.3 \\
\hline & & Coef. Var. & 0.03 & 0.1 & \\
\hline
\end{tabular}

Shackelford Spring, August 1990-September 1991

\begin{tabular}{|c|c|c|c|c|c|}
\hline $\begin{array}{l}\text { Sample } \\
\text { Number }\end{array}$ & Date & Time (CST) & Field $p H$ & $\begin{array}{c}\text { Field Specific } \\
\text { Conductance } \\
\left.\text { (at } 25^{\circ} \mathrm{C}\right) \\
(\mu S)\end{array}$ & $\begin{array}{c}\text { Water } \\
\text { Temperature } \\
\left({ }^{\circ} \mathrm{C}\right)\end{array}$ \\
\hline SKSP0001 & Aug/02/1990 & $7: 10$ & 6.10 & 486 & 15.9 \\
\hline SKSP0002 & Feb/28/1991 & $13: 25$ & 6.83 & 384 & 12.7 \\
\hline SKSP0003 & May/01/1991 & 7:05 & 6.70 & 411 & 12.8 \\
\hline SKSP0004 & May/22/1991 & $7: 45$ & 6.46 & 418 & 13.6 \\
\hline SKSP0005 & Jul/25/1991 & $7: 20$ & 6.58 & 428 & 16.1 \\
\hline SKSP0006 & Aug/29/1991 & 10:00 & 6.54 & 348 & 17.3 \\
\hline SKSP0007 & Sep/24/1991 & $6: 40$ & 6.20 & 394 & 17.7 \\
\hline \multicolumn{3}{|c|}{ Average $^{*}$} & 6.49 & $\overline{410}$ & $\overline{15.2}$ \\
\hline \multicolumn{3}{|r|}{ Maximum } & 6.83 & 486 & 17.7 \\
\hline \multicolumn{3}{|r|}{ Minimum } & 6.10 & 348 & 12.7 \\
\hline \multicolumn{3}{|r|}{ Stand. Dev. } & 0.26 & 42.7 & $\overline{2.1}$ \\
\hline \multicolumn{3}{|c|}{ Coef. Var. } & 0.04 & 0.1 & 0.1 \\
\hline
\end{tabular}

*These statistics are presented as a descriptive summary of the table. The effects of aliasing and variable sampling intervals may significantly affect the validity of averages presented as representative of ground-water quality in the basin. No data means an analysis was not performed. 
Thad Flowers blue hole, August 1990-September 1991

\begin{tabular}{|c|c|c|c|c|c|}
\hline $\begin{array}{l}\text { Sample } \\
\text { Number }\end{array}$ & Date & Time (CST) & Field $p H$ & $\begin{array}{c}\text { Field Specific } \\
\text { Conductance } \\
\left.\text { (at } 25^{\circ} \mathrm{C}\right) \\
(\mu S)\end{array}$ & $\begin{array}{c}\text { Water } \\
\text { Temperature } \\
\left({ }^{\circ} \mathrm{C}\right)\end{array}$ \\
\hline TFBH0001 & Feb/28/1991 & 12:05 & 6.80 & 356 & 13.8 \\
\hline TFBH0002 & May/01/1991 & $7: 45$ & 6.64 & 399 & 13.2 \\
\hline TFBH0003 & May/22/1991 & $6: 50$ & 6.06 & 397 & 13.0 \\
\hline TFBH0004 & Jun/26/1991 & $7: 15$ & 6.35 & 386 & 19.8 \\
\hline TFBH0005 & $\mathrm{Jul} / 25 / 1991$ & 11:10 & 6.92 & 506 & 22.6 \\
\hline TFBH0006 & Aug/29/1991 & $9: 25$ & 6.01 & 110 & 23.0 \\
\hline & & Average* $^{*}$ & 6.46 & 359 & $\overline{17.6}$ \\
\hline & & Maximum & 6.92 & 506 & 23.0 \\
\hline & & Minimum & 6.01 & 110 & 13.0 \\
\hline & & Stand. Dev. & 0.38 & 132.2 & 4.8 \\
\hline & & Coef. Var. & 0.06 & 0.4 & 0.3 \\
\hline
\end{tabular}

George Delaney swallow hole, August 1990-September 1991

\begin{tabular}{|c|c|c|c|c|c|}
\hline $\begin{array}{l}\text { Sample } \\
\text { Number }\end{array}$ & Date & Time (CST) & Field $p H$ & $\begin{array}{c}\text { Field Specific } \\
\text { Conductance } \\
\left.\text { (at } 25^{\circ} \mathrm{C}\right) \\
(\mu S)\end{array}$ & $\begin{array}{c}\text { Water } \\
\text { Temperature } \\
\left({ }^{\circ} \mathrm{C}\right)\end{array}$ \\
\hline GDSW0001 & May/22/1991 & $10: 30$ & 7.00 & 432 & 16.8 \\
\hline GDSW0002 & Jun/26/1991 & $8: 50$ & 6.70 & 372 & 17.3 \\
\hline GDSW0003 & Jul/25/1991 & $8: 55$ & 7.19 & 438 & 20.2 \\
\hline & & Average $^{*}$ & 6.96 & 414 & $\overline{18.1}$ \\
\hline & & Maximum & 7.19 & 438 & 20.2 \\
\hline & & Minimum & 6.70 & 372 & 16.8 \\
\hline
\end{tabular}

*These statistics are presented as a descriptive summary of the table. The effects of aliasing and variable sampling intervals may significantly affect the validity of averages presented as representative of ground-water quality in the basin. No data means an analysis was not performed. 
Pleasant Grove Spring, October 1991-September 1992

\begin{tabular}{|c|c|c|c|c|c|}
\hline $\begin{array}{l}\text { Sample } \\
\text { Number }\end{array}$ & Date & Time (CST) & Field $p H$ & $\begin{array}{c}\text { Field Specific } \\
\text { Conductance } \\
\left.\text { (at } 25^{\circ} \mathrm{C}\right) \\
(\mu S)\end{array}$ & $\begin{array}{c}\text { Water } \\
\text { Temperature } \\
\left({ }^{\circ} \mathrm{C}\right)\end{array}$ \\
\hline PGSP0009 & Oct/22/1991 & $8: 50$ & 6.55 & 483 & 14.4 \\
\hline PGSP0010 & $\mathrm{Dec} / 17 / 1991$ & $8: 06$ & 6.14 & 438 & 12.6 \\
\hline PGSP0011 & Jan/29/1992 & $11: 00$ & 6.56 & 557 & 13.2 \\
\hline PGSP0012 & Feb/26/1992 & $12: 15$ & 6.12 & 505 & 13.4 \\
\hline PGSP0013 & Mar/25/1992 & $13: 20$ & $\overline{7.04}$ & 334 & 13.4 \\
\hline PGSP0014 & Apr/01/1992 & $16: 16$ & 6.96 & 295 & 13.9 \\
\hline PGSP0015 & Apr/09/1992 & $15: 28$ & 6.96 & 304 & 14.5 \\
\hline PGSP0021 & Apr/29/1992 & $9: 40$ & 7.23 & & 15.7 \\
\hline PGSP0026 & May/27/1992 & $10: 45$ & 7.12 & 325 & 14.5 \\
\hline PGSP0027 & Jun/03/1992 & $15: 45$ & 7.19 & 412 & 14.3 \\
\hline PGSP0052 & Jun/04/1992 & $17: 15$ & 7.09 & 316 & 14.7 \\
\hline PGSP0053 & Jun/10/1992 & $13: 20$ & 7.21 & 400 & 14.7 \\
\hline PGSP0054 & Jun/18/1992 & $9: 30$ & 7.07 & 352 & 14.9 \\
\hline \multirow[t]{6}{*}{ PGSP0062 } & Aug/26/1992 & $11: 30$ & 7.04 & 365 & 15.3 \\
\hline & & Average* & 6.88 & 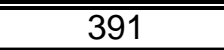 & $\overline{14.5}$ \\
\hline & & Maximum & 7.73 & 557 & 15.7 \\
\hline & & Minimum & 6.12 & 295 & 12.6 \\
\hline & & Stand. Dev. & 0.38 & 83.6 & 0.9 \\
\hline & & Coef. Var. & 0.06 & 0.2 & 0.10 \\
\hline
\end{tabular}

Spring Valley karst window, October 1991-September 1992

\begin{tabular}{|c|c|c|c|c|c|}
\hline $\begin{array}{l}\text { Sample } \\
\text { Number }\end{array}$ & Date & Time (CST) & Field pH & $\begin{array}{c}\text { Field Specific } \\
\text { Conductance } \\
\left.\text { (at } 25^{\circ} \mathrm{C}\right) \\
(\mu S)\end{array}$ & $\begin{array}{c}\text { Water } \\
\text { Temperature } \\
\left({ }^{\circ} \mathrm{C}\right)\end{array}$ \\
\hline SVKW0008 & Oct/22/1991 & $8: 00$ & 6.33 & 483 & 14.2 \\
\hline SVKW0009 & Jan/29/1992 & 10:00 & 6.09 & 555 & 13.3 \\
\hline SVKW0010 & Feb/26/1992 & 11:00 & 6.76 & 505 & 13.3 \\
\hline SVKW0011 & Mar/25/1992 & $10: 55$ & 6.93 & 351 & 13.3 \\
\hline SVKW0013 & Apr/29/1992 & $8: 40$ & 7.10 & & 16.0 \\
\hline SVKW0014 & May/27/1992 & $9: 15$ & 7.16 & 300 & 18.1 \\
\hline & & Average $^{*}$ & 6.73 & 439 & 14.7 \\
\hline & & Maximum & 7.16 & 555 & 18.1 \\
\hline & & Minimum & 6.09 & 300 & 13.3 \\
\hline & & Stand. Dev. & 0.43 & 108.2 & 2.0 \\
\hline & & Coef. Var. & 0.06 & 0.2 & 0.1 \\
\hline
\end{tabular}

\footnotetext{
*These statistics are presented as a descriptive summary of the table. The effects of aliasing and variable sampling intervals may significantly affect the validity of averages presented as representative of ground-water quality in the basin. No data means an analysis was not performed.
} 
The Canyon karst window, October 1991-September 1992

\begin{tabular}{|c|c|c|c|c|c|}
\hline $\begin{array}{c}\text { Sample } \\
\text { Number }\end{array}$ & Date & Time $(\mathrm{CST})$ & Field $\mathrm{pH}$ & $\begin{array}{c}\text { Field Specific } \\
\text { Conductance } \\
\left(\text { at } 25^{\circ} \mathrm{C}\right) \\
(\mu \mathrm{S})\end{array}$ & $\begin{array}{c}\text { Water } \\
\text { Temperature } \\
\left({ }^{\circ} \mathrm{C}\right)\end{array}$ \\
\hline TCKW0008 & Dec/17/1991 & $11: 30$ & 6.36 & 462 & 13.2 \\
\hline TCKW0009 & $\mathrm{Jan} / 29 / 1992$ & $8: 30$ & 6.01 & 559 & 14.0 \\
\hline TCKW0010 & Feb/26/1992 & $9: 45$ & 6.56 & 508 & 14.1 \\
\hline TCKW0011 & Mar/25/1992 & $12: 00$ & 6.99 & 356 & 14.1 \\
\hline TCKW0013 & Apr/29/1992 & $7: 40$ & 7.04 & & 14.6 \\
\hline TCKW0014 & May/27/1992 & $10: 05$ & 6.92 & 310 & 17.6 \\
\hline \hline \multicolumn{7}{|c|}{ Average } & 6.65 & 439 & 14.6 \\
\hline Maximum & 7.04 & 559 & 17.6 \\
\hline Minimum & 6.01 & 310 & 13.2 \\
\hline Stand. Dev. & 0.41 & 103.9 & 1.5 \\
\hline Coef. Var. & 0.06 & 0.2 & 0.1 \\
\hline \hline Total of 6 observations
\end{tabular}

Shackelford Spring, October 1991-September 1992

\begin{tabular}{|c|c|c|c|c|c|}
\hline $\begin{array}{l}\text { Sample } \\
\text { Number }\end{array}$ & Date & Time (CST) & Field $p H$ & $\begin{array}{c}\text { Field Specific } \\
\text { Conductance } \\
\left.\text { (at } 25^{\circ} \mathrm{C}\right) \\
(\mu \mathrm{S})\end{array}$ & $\begin{array}{c}\text { Water } \\
\text { Temperature } \\
\left({ }^{\circ} \mathrm{C}\right)\end{array}$ \\
\hline SKSP0008 & Oct/22/1991 & $6: 34$ & 6.24 & 473 & 17.3 \\
\hline SKSP0009 & $\mathrm{Dec} / 17 / 1991$ & $12: 00$ & 6.15 & 492 & 14.5 \\
\hline SKSP0010 & Jan/29/1992 & $14: 30$ & 6.37 & 534 & 13.0 \\
\hline SKSP0011 & Feb/26/1992 & $8: 40$ & 5.37 & 465 & 12.0 \\
\hline SKSP0012 & Mar/25/1992 & $8: 40$ & 7.10 & 413 & 12.4 \\
\hline SKSP0013 & Apr/29/1992 & $6: 43$ & 7.25 & & 12.6 \\
\hline SKSP0014 & May/27/1992 & $11: 50$ & 7.16 & 280 & 16.5 \\
\hline \multicolumn{3}{|c|}{ Average $^{*}$} & 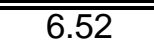 & 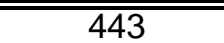 & 14.0 \\
\hline \multicolumn{3}{|c|}{ Maximum } & 7.25 & 534 & 17.3 \\
\hline \multicolumn{3}{|c|}{$\begin{array}{ll}\text { Minimum } \\
\end{array}$} & 5.37 & 280 & 12.0 \\
\hline \multicolumn{3}{|c|}{ 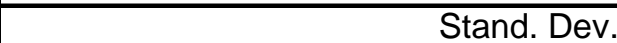 } & 0.69 & 88.9 & 2.1 \\
\hline \multicolumn{3}{|c|}{ Coef. Var. } & 0.11 & 0.2 & 0.2 \\
\hline
\end{tabular}

*These statistics are presented as a descriptive summary of the table. The effects of aliasing and variable sampling intervals may significantly affect the validity of averages presented as representative of ground-water quality in the basin. No data means an analysis was not performed. 
Thad Flowers blue hole, October 1991-September 1992

\begin{tabular}{|c|c|c|c|c|c|}
\hline $\begin{array}{c}\text { Sample } \\
\text { Number }\end{array}$ & Date & Time (CST) & Field $\mathrm{pH}$ & $\begin{array}{c}\text { Field Specific } \\
\text { Conductance } \\
\left(\text { at 25 }{ }^{\circ} \mathrm{C}\right) \\
(\mu S)\end{array}$ & $\begin{array}{c}\text { Water } \\
\text { Temperature } \\
\left({ }^{\circ} \mathrm{C}\right)\end{array}$ \\
\hline TFBH0007 & Dec/17/1991 & $13: 30$ & 6.24 & 446 & 14.4 \\
\hline TFBH0008 & Jan/29/1992 & $7: 50$ & 6.81 & 440 & 6.5 \\
\hline TFBH0009 & Feb/26/1992 & $7: 30$ & 6.86 & 342 & 7.5 \\
\hline TFBH0010 & Mar/25/1992 & $7: 20$ & 7.30 & 337 & 13.0 \\
\hline \hline \multicolumn{7}{|c|}{ Average ${ }^{*}$} & 6.80 & 391 & 10.4 \\
\hline Maximum & 7.30 & 446 & 14.4 \\
\hline Minimum & 6.24 & 337 & 6.5 \\
\hline Stand. Dev. & 0.43 & 59.8 & 3.9 \\
\hline \hline Coef. Var. & 0.06 & 0.2 & 0.4 \\
\hline \hline
\end{tabular}

George Delaney swallow hole, October 1991-September 1992

\begin{tabular}{|c|c|c|c|c|c|}
\hline $\begin{array}{c}\text { Sample } \\
\text { Number }\end{array}$ & Date & Time (CST) & Field $\mathrm{pH}$ & $\begin{array}{c}\text { Field Specific } \\
\text { Conductance } \\
\left(\text { at 25 }{ }^{\circ} \mathrm{C}\right) \\
(\mu S)\end{array}$ & $\begin{array}{c}\text { Water } \\
\text { Temperature } \\
\left({ }^{\circ} \mathrm{C}\right)\end{array}$ \\
\hline GDSW0004 & Dec/17/1991 & $10: 00$ & 6.83 & 408 & 9.8 \\
\hline GDSW0005 & Jan/29/1992 & $9: 10$ & 6.91 & 469 & 7.9 \\
\hline GDSW0006 & Feb/26/1992 & $10: 20$ & 7.42 & 415 & 7.8 \\
\hline GDSW0007 & Mar/25/1992 & $9: 45$ & 7.71 & 389 & 10.7 \\
\hline \hline \multicolumn{7}{|c|}{ Average } & 7.22 & 420 & 9.1 \\
\hline Maximum & 7.71 & 469 & 10.7 \\
\hline Minimum & 6.83 & 389 & 7.8 \\
\hline Stand. Dev. & 0.42 & 34.3 & 1.4 \\
\hline \hline Coef. Var. & 0.06 & 0.1 & 0.2 \\
\hline \hline
\end{tabular}

*These statistics are presented as a descriptive summary of the table. The effects of aliasing and variable sampling intervals may significantly affect the validity of averages presented as representative of ground-water quality in the basin. No data means an analysis was not performed. 
Pleasant Grove Spring, October 1992-September 1993

\begin{tabular}{|c|c|c|c|c|c|}
\hline $\begin{array}{l}\text { Sample } \\
\text { Number }\end{array}$ & Date & Time (CST) & Field $p H$ & $\begin{array}{c}\text { Field Specific } \\
\text { Conductance } \\
\left(\text { at } 25^{\circ} \mathrm{C}\right) \\
(\mu \mathrm{S})\end{array}$ & $\begin{array}{c}\text { Water } \\
\text { Temperature } \\
\left({ }^{\circ} \mathrm{C}\right)\end{array}$ \\
\hline PGSP0065 & Oct/06/1992 & $12: 50$ & 7.14 & 382 & 16.1 \\
\hline PGSP0067 & Nov/06/1992 & 9:00 & 6.93 & 643 & 14.3 \\
\hline PGSP0070 & $\mathrm{Dec} / 03 / 1992$ & 9:07 & 7.43 & 709 & 14.1 \\
\hline PGSP0071 & $\mid \operatorname{Jan} / 08 / 1993$ & $10: 19$ & 6.62 & 481 & 13.0 \\
\hline PGSP0108 & Feb/04/1993 & $10: 00$ & 7.40 & 536 & 13.0 \\
\hline PGSP0159 & Mar/05/1993 & $10: 00$ & 7.20 & 250 & 12.2 \\
\hline PGSP0211 & Apr/07/1993 & $8: 22$ & 7.18 & 468 & 14.1 \\
\hline PGSP0215 & May/04/1993 & $13: 55$ & 6.87 & 226 & 14.7 \\
\hline PGSP0255 & May/20/1993 & $9: 42$ & 7.23 & 744 & 14.5 \\
\hline PGSP0264 & Jun/02/1993 & $14: 30$ & 7.26 & 420 & 14.7 \\
\hline PGSP0299 & Aug/04/1993 & 9:00 & 7.16 & 642 & 14.6 \\
\hline PGSP0302 & Sep/09/1993 & $7: 30$ & 7.24 & 484 & 14.8 \\
\hline \multicolumn{3}{|c|}{$\begin{array}{|lc|}\text { Average }^{*} \\
\end{array}$} & 7.14 & 499 & 14.2 \\
\hline \multicolumn{3}{|c|}{\begin{tabular}{|l|} 
Maximum \\
\end{tabular}} & 7.43 & 744 & 16.1 \\
\hline \multicolumn{3}{|r|}{ Minimum } & 6.62 & 226 & 12.2 \\
\hline \multicolumn{3}{|r|}{ Stand. Dev. } & 0.23 & 166.4 & 1.0 \\
\hline \multicolumn{3}{|c|}{ | Total of 12 observations } & 0.03 & 0.3 & 0.1 \\
\hline
\end{tabular}

Spring Valley karst window, October 1992-September 1993

\begin{tabular}{|c|c|c|c|c|c|}
\hline $\begin{array}{c}\text { Sample } \\
\text { Number }\end{array}$ & Date & Time (CST) & Field $\mathrm{pH}$ & $\begin{array}{c}\text { Field Specific } \\
\text { Conductance } \\
\left(\text { at } 25^{\circ} \mathrm{C}\right) \\
(\mu \mathrm{S})\end{array}$ & $\begin{array}{c}\text { Water } \\
\text { Temperature } \\
\left({ }^{\circ} \mathrm{C}\right)\end{array}$ \\
\hline SVKW0015 & May/20/1993 & $9: 20$ & 7.20 & 565 & 14.7 \\
\hline SVKW0017 & Jun/02/1993 & $12: 55$ & 7.25 & 337 & 14.6 \\
\hline \hline \multicolumn{7}{|c|}{ Average } & 7.23 & 451 & 14.7 \\
\hline \hline
\end{tabular}

*These statistics are presented as a descriptive summary of the table. The effects of aliasing and variable sampling intervals may significantly affect the validity of averages presented as representative of ground-water quality in the basin. No data means an analysis was not performed. 
George Delaney swallow hole, October 1992-September 1993

\begin{tabular}{|c|c|c|c|c|c|}
\hline $\begin{array}{c}\text { Sample } \\
\text { Number }\end{array}$ & Date & Time (CST) & Field $\mathrm{pH}$ & $\begin{array}{c}\text { Field Specific } \\
\text { Conductance } \\
\left(\text { at } 25^{\circ} \mathrm{C}\right) \\
(\mu S)\end{array}$ & $\begin{array}{c}\text { Water } \\
\text { Temperature } \\
\left({ }^{\circ} \mathrm{C}\right)\end{array}$ \\
\hline GDSW0009 & May/20/1993 & $8: 14$ & 7.00 & 533 & 14.5 \\
\hline GDSW010A & Jun/03/1993 & $8: 45$ & 7.78 & 431 & 16.2 \\
\hline \hline \multicolumn{7}{|c|}{ Average $^{\star}$} & 7.39 & 482 & 15.4 \\
\hline \hline Total of 2 observations
\end{tabular}

Leslie Page karst window, October 1992-September 1993

\begin{tabular}{|c|c|c|c|c|c|}
\hline $\begin{array}{c}\text { Sample } \\
\text { Number }\end{array}$ & Date & Time $(\mathrm{CST})$ & Field $\mathrm{pH}$ & $\begin{array}{c}\text { Field Specific } \\
\text { Conductance } \\
\left(\begin{array}{c}\left.\text { at 25 }{ }^{\circ} \mathrm{C}\right) \\
(\mu \mathrm{S})\end{array}\right.\end{array}$ & $\begin{array}{c}\text { Water } \\
\text { Temperature } \\
\left({ }^{\circ} \mathrm{C}\right)\end{array}$ \\
\hline LPKW0009 & May/20/1993 & $11: 10$ & 7.60 & 157 & 13.9 \\
\hline LPKW010A & Jun/02/1993 & $16: 50$ & 7.40 & 208 & 14.7 \\
\hline LPKW0014 Jun/30/1993 & $9: 45$ & 7.65 & 229 & 15.9 \\
\hline \hline \multicolumn{7}{|c|}{ Average } & 7.56 & 180 & 14.6 \\
\hline \multicolumn{7}{|c|}{ Maximum } & 7.65 & 229 & 15.9 \\
\hline \multicolumn{7}{|c|}{ Minimum } & 7.40 & 125 & 13.9 \\
\hline \hline Total of 3 observations
\end{tabular}

Upper Pleasant Grove Creek, October 1992-September 1993

\begin{tabular}{|c|c|c|c|c|c|}
\hline $\begin{array}{c}\text { Sample } \\
\text { Number }\end{array}$ & Date & Time (CST) & Field $\mathrm{pH}$ & $\begin{array}{c}\text { Field Specific } \\
\text { Conductance } \\
\left(\text { at } 25^{\circ} \mathrm{C}\right) \\
(\mu S)\end{array}$ & $\begin{array}{c}\text { Water } \\
\text { Temperature } \\
\left({ }^{\circ} \mathrm{C}\right)\end{array}$ \\
\hline UPGC0002 & Jun/30/1993 & $9: 10$ & 7.65 & 387 & 21.4 \\
\hline UPGC0003 & Aug/03/1993 & $15: 33$ & 8.52 & 414 & 28.2 \\
\hline \hline \multicolumn{7}{|c|}{ Average* } & 8.09 & 401 & 24.8 \\
\hline \hline Total of 2 observations
\end{tabular}

*These statistics are presented as a descriptive summary of the table. The effects of aliasing and variable sampling intervals may significantly affect the validity of averages presented as representative of ground-water quality in the basin. No data means an analysis was not performed. 
Pleasant Grove Spring, October 1993-September 1994

\begin{tabular}{|c|c|c|c|c|c|}
\hline $\begin{array}{l}\text { Sample } \\
\text { Number }\end{array}$ & Date & Time (CST) & Field $\mathrm{pH}$ & $\begin{array}{c}\text { Field Specific } \\
\text { Conductance } \\
\left.\text { (at } 25^{\circ} \mathrm{C}\right) \\
(\mu S)\end{array}$ & $\begin{array}{c}\text { Water } \\
\text { Temperature } \\
\left({ }^{\circ} \mathrm{C}\right)\end{array}$ \\
\hline PGSP0303 & Oct/06/1993 & $7: 30$ & 7.13 & 421 & 14.4 \\
\hline PGSP0304 & Nov/09/1993 & $10: 45$ & 7.36 & 347 & 14.0 \\
\hline PGSP0334 & Jan/12/1994 & $11: 40$ & 7.11 & 390 & 12.1 \\
\hline PGSP0342 & Feb/02/1994 & $12: 10$ & 7.13 & 237 & 11.8 \\
\hline PGSP0343 & Feb/22/1994 & $11: 20$ & 7.00 & 202 & 13.0 \\
\hline PGSP0344 & Mar/01/1994 & $11: 00$ & 7.45 & 136 & 12.7 \\
\hline PGSP0364 & Mar/28/1994 & $13: 00$ & 7.01 & 200 & 12.3 \\
\hline PGSP & Apr/20/1994 & $11: 15$ & $\overline{7.10}$ & 173 & 14.4 \\
\hline PGSP0410 & Apr/26/1994 & $6: 00$ & 7.21 & 374 & 15.0 \\
\hline PGSP0412 & Apr/27/1994 & $10: 00$ & 7.25 & 356 & 15.6 \\
\hline PGSP0413 & Apr/28/1994 & $6: 00$ & 7.23 & 352 & 15.8 \\
\hline PGSP0449 & May/12/1994 & 9:00 & 7.19 & 392 & 14.5 \\
\hline PGSP & May/17/1994 & 13:57 & 7.13 & 417 & 16.5 \\
\hline PGSP0463 & Jun/01/1994 & $12: 00$ & 7.23 & 423 & 14.3 \\
\hline PGSP0529 & Jul/06/1994 & $10: 30$ & & 350 & \\
\hline PGSP0538 & Aug/03/1994 & $8: 30$ & 6.93 & 360 & 14.5 \\
\hline \multicolumn{3}{|c|}{$\begin{array}{ll}\text { Average }^{*} \\
\end{array}$} & 7.16 & 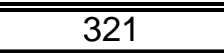 & $\overline{14.1}$ \\
\hline \multicolumn{3}{|c|}{$\begin{array}{ll}\text { Maximum } \\
\end{array}$} & 7.45 & 423 & 16.5 \\
\hline \multicolumn{3}{|r|}{ Minimum } & 6.93 & 136 & 11.8 \\
\hline \multicolumn{3}{|r|}{ Stand. Dev. } & 0.13 & 96.4 & 1.4 \\
\hline \multicolumn{3}{|c|}{ Coef. Var. } & 0.02 & 0.3 & 0.1 \\
\hline
\end{tabular}

George Delaney swallow hole, October 1993-September 1994

\begin{tabular}{|c|c|c|c|c|c|}
\hline $\begin{array}{l}\text { Sample } \\
\text { Number }\end{array}$ & Date & Time (CST) & Field $p H$ & $\begin{array}{c}\text { Field Specific } \\
\text { Conductance } \\
\left.\text { (at } 25^{\circ} \mathrm{C}\right) \\
(\mu S)\end{array}$ & $\begin{array}{c}\text { Water } \\
\text { Temperature } \\
\left({ }^{\circ} \mathrm{C}\right)\end{array}$ \\
\hline GDSW0013 & Mar/28/1994 & $10: 40$ & & 190 & 10.1 \\
\hline GDSW0015 & Apr/20/1994 & $12: 10$ & 7.80 & 191 & 16.1 \\
\hline GDSW0016 & Apr/26/1994 & $15: 30$ & 8.14 & 376 & 19.3 \\
\hline GDSW0017 & May/12/1994 & $9: 50$ & 7.90 & 408 & 15.0 \\
\hline GDSW0018 & May/17/1994 & $13: 28$ & 7.92 & 426 & 18.0 \\
\hline GDSW0019 & Jun/01/1994 & $7: 36$ & 7.65 & 406 & 16.1 \\
\hline \multirow[t]{6}{*}{ GDSW0021 } & Jul/06/1994 & $9: 45$ & & 400 & \\
\hline & & Average* $^{\star}$ & $\overline{7.88}$ & 342 & $\overline{15.8}$ \\
\hline & & Maximum & 8.14 & 426 & 19.3 \\
\hline & & Minimum & 7.65 & 190 & 10.1 \\
\hline & & Stand. Dev. & 0.18 & 104.8 & 3.2 \\
\hline & & Coef. Var. & 0.02 & 0.3 & 0.2 \\
\hline \multicolumn{6}{|c|}{ Total of 7 observations } \\
\hline
\end{tabular}

*These statistics are presented as a descriptive summary of the table. The effects of aliasing and variable sampling intervals may significantly affect the validity of averages presented as representative of ground-water quality in the basin. No data means an analysis was not performed. 
Leslie Page karst window, October 1993-September 1994

\begin{tabular}{|c|c|c|c|c|c|}
\hline $\begin{array}{l}\text { Sample } \\
\text { Number }\end{array}$ & Date & Time (CST) & Field pH & $\begin{array}{c}\text { Field Specific } \\
\text { Conductance } \\
\left.\text { (at } 25^{\circ} \mathrm{C}\right) \\
(\mu \mathrm{S})\end{array}$ & $\begin{array}{c}\text { Water } \\
\text { Temperature } \\
\left({ }^{\circ} \mathrm{C}\right)\end{array}$ \\
\hline LPKW0019 & Oct/05/1993 & $13: 20$ & 7.70 & 167 & 15.1 \\
\hline LPKW0020 & Nov/09/1993 & $9: 35$ & 7.75 & 121 & 12.5 \\
\hline LPKW0022 & Jan/11/1994 & $14: 23$ & 6.70 & 124 & 14.1 \\
\hline LPKW0023 & Feb/02/1994 & $9: 55$ & 6.92 & 20 & 12.5 \\
\hline LPKW0024 & Feb/22/1994 & 13:30 & 6.21 & 40 & 14.0 \\
\hline LPKW0080 & Apr/27/1994 & $8: 31$ & 6.94 & 219 & 14.0 \\
\hline LPKW0090 & May/12/1994 & $10: 40$ & 6.53 & 176 & 14.0 \\
\hline LPKW & May/17/1994 & $12: 48$ & 7.05 & 198 & 16.5 \\
\hline LPKW0104 & Jun/01/1994 & $8: 30$ & 6.62 & 241 & 13.8 \\
\hline LPKW0106 & Jun/27/1994 & $23: 50$ & & 230 & \\
\hline LPKW0109 & Aug/02/1994 & $14: 20$ & 6.41 & 209 & 14.9 \\
\hline & & Average* & 6.88 & 159 & 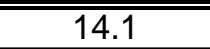 \\
\hline & & Maximum & 7.75 & 241 & 16.5 \\
\hline & & Minimum & 6.21 & 20 & 12.5 \\
\hline & & Stand. Dev. & 0.51 & 74.8 & 1.2 \\
\hline & & Coef. Var. & 0.07 & 0.5 & 0.1 \\
\hline
\end{tabular}

Upper Pleasant Grove Creek, October 1993-September 1994

\begin{tabular}{|c|c|c|c|c|c|}
\hline $\begin{array}{l}\text { Sample } \\
\text { Number }\end{array}$ & Date & Time (CST) & Field $p H$ & $\begin{array}{c}\text { Field Specific } \\
\text { Conductance } \\
\left(\text { at } 25^{\circ} \mathrm{C}\right) \\
(\mu S)\end{array}$ & $\begin{array}{c}\text { Water } \\
\text { Temperature } \\
\left({ }^{\circ} \mathrm{C}\right)\end{array}$ \\
\hline UPGC0006 & Feb/22/1994 & $15: 16$ & 7.50 & 162 & 11.0 \\
\hline UPGC0007 & Mar/28/1994 & $11: 05$ & & 185 & 11.5 \\
\hline UPGC0009 & \begin{tabular}{|l|l|} 
Apr/20/1994 \\
\end{tabular} & $12: 25$ & 7.88 & 175 & 19.5 \\
\hline UPGC0010 & Apr/27/1994 & 7:10 & 7.63 & 380 & 15.8 \\
\hline UPGC0011 & May/12/1994 & $10: 10$ & 7.84 & 408 & 17.0 \\
\hline UPGC0012 & May/17/1994 & $12: 13$ & 8.03 & 416 & 22.0 \\
\hline UPGC0013 & \begin{tabular}{|l|}
$J u n / 01 / 1994$ \\
\end{tabular} & $7: 07$ & 7.77 & 437 & 15.1 \\
\hline \multirow[t]{6}{*}{ UPGC0015 } & Jul/06/1994 & $7: 30$ & & 365 & \\
\hline & & Average* $^{*}$ & 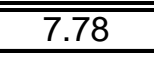 & $\overline{\overline{316}}$ & 16.0 \\
\hline & & Maximum & 8.03 & 437 & 22.0 \\
\hline & & Minimum & 7.50 & 162 & 11.0 \\
\hline & & Stand. Dev. & 0.19 & 119.7 & 4.0 \\
\hline & & Coef. Var. & 0.02 & 0.4 & 0.2 \\
\hline \multicolumn{6}{|c|}{ Total of 8 observations } \\
\hline
\end{tabular}

*These statistics are presented as a descriptive summary of the table. The effects of aliasing and variable sampling intervals may significantly affect the validity of averages presented as representative of ground-water quality in the basin. No data means an analysis was not performed. 
Miller School House water well, October 1993-September 1994

\begin{tabular}{|c|c|c|c|c|c|}
\hline $\begin{array}{c}\text { Sample } \\
\text { Number }\end{array}$ & Date & Time (CST) & Field $\mathrm{pH}$ & $\begin{array}{c}\text { Field Specific } \\
\text { Conductance } \\
\left(\text { at } 25^{\circ} \mathrm{C}\right) \\
(\mu \mathrm{S})\end{array}$ & $\begin{array}{c}\text { Water } \\
\text { Temperature } \\
\left({ }^{\circ} \mathrm{C}\right)\end{array}$ \\
\hline MSHW0001 & Apr/26/1994 & $14: 00$ & 7.43 & 615 & 15.5 \\
\hline \hline
\end{tabular}

*These statistics are presented as a descriptive summary of the table. The effects of aliasing and variable sampling intervals may significantly affect the validity of averages presented as representative of ground-water quality in the basin. No data means an analysis was not performed. 


\section{APPENDIX G: \\ Water Sample Analyses and Descriptive Statistics for the Pleasant Grove Spring Drainage Basin}


Pleasant Grove Spring, August 1990-September 1991

\begin{tabular}{|c|c|c|c|c|c|c|c|}
\hline $\begin{array}{l}\text { Sample } \\
\text { Number }\end{array}$ & Date & Time (CST) & $\begin{array}{c}\text { Total Nitrate- } \\
\text { Nitrogen } \\
(m g / L \text { as } N)\end{array}$ & $\begin{array}{c}\text { Total Nitrite } \\
(\mathrm{mg} / \mathrm{L} \text { as } \\
\left.\mathrm{NO}_{2}^{-}\right)\end{array}$ & $\begin{array}{c}\text { Ammonia } \\
(\mathrm{mg} / \mathrm{L} \text { as } \\
\left.\mathrm{NH}_{3}\right)\end{array}$ & $\begin{array}{c}\text { Total } \\
\text { Kjeldahl } \\
\text { Nitrogen } \\
(\mathrm{mg} / \mathrm{L} \text { as } \mathrm{N})\end{array}$ & $\begin{array}{l}\text { Orthophosphate } \\
\left(\mathrm{mg} / \mathrm{L} \text { as } \mathrm{PO}_{4}{ }^{-3}\right)\end{array}$ \\
\hline PGSP0001 & Aug/02/1990 & $11: 15$ & 4.10 & & & & \\
\hline PGSP0002 & Feb/28/1991 & $9: 55$ & 4.50 & $<0.01$ & 0.080 & $<0.030$ & $<0.010$ \\
\hline PGSP0003 & May/01/1991 & $10: 10$ & 4.80 & 0.011 & 0.080 & $<0.030$ & 0.020 \\
\hline PGSP0004 & May/22/1991 & $11: 30$ & 4.30 & 0.036 & 0.040 & $<0.030$ & 0.048 \\
\hline PGSP0005 & Jun/26/1991 & $9: 42$ & 4.20 & 0.006 & 0.030 & $<0.030$ & 0.048 \\
\hline PGSP0006 & 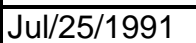 & $10: 15$ & 4.20 & 0.003 & 0.030 & $<0.030$ & 0.050 \\
\hline PGSP0007 & Aug/29/1991 & $12: 30$ & 3.82 & 0.003 & 0.020 & $<0.030$ & 0.040 \\
\hline PGSP0008 & Sep/24/1991 & $9: 30$ & 3.57 & & & & 0.048 \\
\hline & & Average* & $\overline{4.19}$ & $\overline{0.012}$ & 0.047 & & 0.038 \\
\hline & & Maximum & 4.80 & 0.036 & 0.080 & $<0.030$ & 0.050 \\
\hline & & Minimum & 3.57 & 0.003 & 0.020 & & $<0.010$ \\
\hline & & Stand. Dev. & 0.38 & 0.011 & 0.027 & & 0.016 \\
\hline & & Coef. Var. & 0.09 & 0.917 & 0.570 & & 0.427 \\
\hline
\end{tabular}

Spring Valley karst window, August 1990-September 1991

\begin{tabular}{|c|c|c|c|c|c|c|c|}
\hline $\begin{array}{l}\text { Sample } \\
\text { Number }\end{array}$ & Date & Time (CST) & $\begin{array}{c}\text { Total Nitrate- } \\
\text { Nitrogen } \\
\text { (mg/L as N) }\end{array}$ & $\begin{array}{c}\text { Total Nitrite } \\
(\mathrm{mg} / \mathrm{L} \text { as } \\
\left.\mathrm{NO}_{2}{ }^{-}\right)\end{array}$ & $\begin{array}{c}\text { Ammonia } \\
(\mathrm{mg} / \mathrm{L} \text { as } \\
\left.\mathrm{NH}_{3}\right)\end{array}$ & $\begin{array}{c}\text { Total } \\
\text { Kjeldahl } \\
\text { Nitrogen } \\
(\mathrm{mg} / \mathrm{L} \text { as } N) \\
\end{array}$ & $\begin{array}{l}\text { Orthophosphate } \\
\left(\mathrm{mg} / \mathrm{L} \text { as } \mathrm{PO}_{4}^{-3}\right)\end{array}$ \\
\hline SVKW0001 & Aug/02/1990 & $10: 00$ & 4.10 & & & & \\
\hline SVKW0002 & Feb/28/1991 & $11: 00$ & 4.70 & $<0.01$ & 0.120 & $<0.030$ & $<0.010$ \\
\hline SVKW0003 & May/22/1991 & $12: 17$ & 4.50 & 0.031 & 0.030 & $<0.030$ & 0.053 \\
\hline SVKW0004 & Jun/26/1991 & $11: 00$ & 4.20 & 0.005 & 0.050 & $<0.030$ & 0.046 \\
\hline SVKW0005 & Jul/25/1991 & 9:30 & 4.20 & 0.006 & 0.030 & $<0.030$ & 0.066 \\
\hline SVKW0006 & Aug/29/1991 & $11: 35$ & 3.80 & 0.003 & 0.010 & $<0.030$ & 0.045 \\
\hline SVKW0007 & Sep/24/1991 & $8: 40$ & 3.57 & & & & 0.043 \\
\hline & & Average $^{\star}$ & 44.15 & "0.011 & 0.048 & & (0.044 \\
\hline & & Maximum & 4.70 & 0.031 & 0.120 & $<0.030$ & 0.066 \\
\hline & & Minimum & 3.57 & 0.003 & 0.010 & & $<0.010$ \\
\hline & & Stand. Dev. & 0.39 & 0.010 & 0.043 & & 0.019 \\
\hline & & Coef. Var. & 0.09 & 0.932 & 0.889 & & 0.424 \\
\hline
\end{tabular}

\footnotetext{
*These statistics are presented as a descriptive summary of the table. The effects of aliasing and variable sampling intervals may significantly affect the validity of averages presented as representative of ground-water quality in the basin. No data means an analysis was not performed.
} 
The Canyon karst window, August 1990-September 1991

\begin{tabular}{|c|c|c|c|c|c|c|c|}
\hline $\begin{array}{l}\text { Sample } \\
\text { Number }\end{array}$ & Date & Time (CST) & $\begin{array}{l}\text { Total Nitrate- } \\
\text { Nitrogen } \\
\text { (mg/L as } N)\end{array}$ & $\begin{array}{c}\text { Total Nitrite } \\
\text { (mg/L as } \\
\left.\mathrm{NO}_{2}{ }^{-}\right)\end{array}$ & $\begin{array}{c}\text { Ammonia } \\
(\mathrm{mg} / \mathrm{L} \text { as } \\
\left.\mathrm{NH}_{3}\right)\end{array}$ & $\begin{array}{c}\text { Total } \\
\text { Kjeldahl } \\
\text { Nitrogen } \\
\text { (mg/L as } \mathrm{N})\end{array}$ & $\begin{array}{l}\text { Orthophosphate } \\
\left(\mathrm{mg} / \mathrm{L}_{\text {as }} \mathrm{PO}_{4}^{-3}\right)\end{array}$ \\
\hline TCKW0001 & Aug/02/1990 & $9: 00$ & 3.90 & & & & \\
\hline TCKW0002 & May/01/1991 & $8: 45$ & 3.50 & 0.005 & 0.010 & $<0.030$ & 0.029 \\
\hline TCKW0003 & May/22/1991 & $9: 30$ & 2.70 & 0.008 & 0.040 & $<0.030$ & 0.049 \\
\hline TCKW0004 & Jun/26/1991 & $7: 45$ & 3.70 & 0.003 & 0.030 & $<0.030$ & 0.032 \\
\hline TCKW0005 & Jul/25/1991 & $8: 24$ & 3.90 & 0.004 & 0.030 & $<0.030$ & 0.046 \\
\hline TCKW0006 & Aug/29/1991 & $10: 45$ & 3.62 & 0.004 & 0.030 & $<0.030$ & 0.042 \\
\hline TCKW0007 & Sep/24/1991 & $7: 40$ & 3.46 & & & & 0.046 \\
\hline & & Average ${ }^{\star}$ & 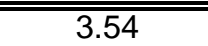 & 0.005 & $\overline{0.028}$ & & $\overline{0.041}$ \\
\hline & & Maximum & 3.90 & 0.008 & 0.040 & $<0.030$ & 0.049 \\
\hline & & Minimum & 2.70 & 0.003 & 0.010 & & 0.049 \\
\hline & & Stand. Dev. & 0.41 & 0.002 & 0.011 & & 0.008 \\
\hline & & Coef. Var. & 0.12 & 0.344 & 0.391 & & 0.203 \\
\hline
\end{tabular}

Shackelford Spring, August 1990-September 1991

\begin{tabular}{|c|c|c|c|c|c|c|c|}
\hline $\begin{array}{l}\text { Sample } \\
\text { Number }\end{array}$ & Date & Time (CST) & $\begin{array}{c}\text { Total Nitrate- } \\
\text { Nitrogen } \\
(\mathrm{mg} / \mathrm{L} \text { as } N)\end{array}$ & $\begin{array}{c}\text { Total Nitrite } \\
(\mathrm{mg} / \mathrm{L} \text { as } \\
\left.\mathrm{NO}_{2}^{-}\right)\end{array}$ & $\begin{array}{c}\text { Ammonia } \\
(\mathrm{mg} / \mathrm{L} \text { as } \\
\left.\mathrm{NH}_{3}\right)\end{array}$ & $\begin{array}{c}\text { Total } \\
\text { Kjeldahl } \\
\text { Nitrogen } \\
(\mathrm{mg} / \mathrm{L} \text { as N) }\end{array}$ & $\begin{array}{l}\text { Orthophosphate } \\
\left(\mathrm{mg} / \mathrm{L}_{\text {as }} \mathrm{PO}_{4}^{-3}\right)\end{array}$ \\
\hline SKSP0001 & Aug/02/1990 & $7: 10$ & 7.10 & & & & \\
\hline SKSP0002 & $\mathrm{Feb} / 28 / 1991$ & $13: 25$ & 7.00 & $<0.01$ & 0.090 & $<0.030$ & $<0.010$ \\
\hline SKSP0003 & May/01/1991 & $7: 05$ & 7.60 & 0.004 & 0.090 & $<0.030$ & 0.024 \\
\hline SKSP0004 & May/22/1991 & $7: 45$ & 7.40 & 0.006 & 0.040 & $<0.030$ & 0.038 \\
\hline SKSP0005 & \begin{tabular}{|l|l|}
$\mathrm{Jul} / 25 / 1991$ \\
\end{tabular} & $7: 20$ & 8.20 & 0.002 & 0.060 & $<0.030$ & 0.055 \\
\hline SKSP0006 & Aug/29/1991 & $10: 00$ & 7.04 & 0.003 & 0.010 & $<0.030$ & 0.058 \\
\hline SKSP0007 & Sep/24/1991 & $6: 40$ & 6.43 & & & & 0.057 \\
\hline & & Average* $^{*}$ & $\overline{7.25}$ & 0.005 & "0.058 & & $\overline{0.040}$ \\
\hline & & Maximum & 8.20 & 0.006 & 0.090 & $<0.030$ & 0.058 \\
\hline & & Minimum & 6.43 & 0.002 & 0.010 & & $<0.010$ \\
\hline & & Stand. Dev. & 0.56 & 0.003 & 0.034 & & 0.020 \\
\hline & & Coef. Var. & 0.08 & 0.566 & 0.590 & & 0.496 \\
\hline
\end{tabular}

\footnotetext{
${ }^{*}$ These statistics are presented as a descriptive summary of the table. The effects of aliasing and variable sampling intervals may significantly affect the validity of averages presented as representative of ground-water quality in the basin. No data means an analysis was not performed.
} 
Thad Flowers blue hole, August 1990-September 1991

\begin{tabular}{|c|c|c|c|c|c|c|c|}
\hline $\begin{array}{l}\text { Sample } \\
\text { Number }\end{array}$ & Date & Time (CST) & $\begin{array}{c}\text { Total Nitrate- } \\
\text { Nitrogen } \\
(m g / L \text { as } N)\end{array}$ & $\begin{array}{c}\text { Total Nitrite } \\
(\mathrm{mg} / \mathrm{L} \text { as } \\
\left.\mathrm{NO}_{2}{ }^{-}\right)\end{array}$ & $\begin{array}{c}\text { Ammonia } \\
(\mathrm{mg} / \mathrm{L} \text { as } \\
\left.\mathrm{NH}_{3}\right) \\
\end{array}$ & $\begin{array}{c}\text { Total } \\
\text { Kjeldahl } \\
\text { Nitrogen } \\
\text { (mg/L as N) }\end{array}$ & $\begin{array}{l}\text { Orthophosphate } \\
\left(\mathrm{mg} / \mathrm{L} \text { as } \mathrm{PO}_{4}{ }^{-3}\right)\end{array}$ \\
\hline TFBH0001 & Feb/28/1991 & $12: 05$ & 6.40 & & 0.050 & $<0.030$ & $<0.010$ \\
\hline TFBH0002 & May/01/1991 & $7: 45$ & 7.00 & 0.013 & 0.050 & $<0.030$ & 0.008 \\
\hline TFBH0003 & May/22/1991 & $6: 50$ & 6.80 & 0.010 & 0.070 & 0.300 & 0.024 \\
\hline TFBH0004 & Jun/26/1991 & $7: 15$ & 4.60 & 0.426 & 0.300 & $<0.030$ & 0.049 \\
\hline TFBH0005 & Jul/25/1991 & $11: 10$ & 0.02 & 0.007 & 4.460 & 0.090 & 0.062 \\
\hline TFBH0006 & Aug/29/1991 & $9: 25$ & 1.04 & 0.208 & 1.020 & $<0.030$ & 0.477 \\
\hline & & Average $^{\star}$ & "4.31 & "0.133 & $\bar{~} 0.992$ & 0.085 & 0.105 \\
\hline & & Maximum & 7.00 & 0.426 & 4.460 & 0.300 & 0.477 \\
\hline & & Minimum & 0.02 & 0.007 & 0.050 & $<0.030$ & $<0.010$ \\
\hline & & Stand. Dev. & 3.06 & 0.165 & 1.740 & & 0.184 \\
\hline & & Coef. Var. & 0.71 & 1.244 & 1.754 & & 1.748 \\
\hline
\end{tabular}

George Delaney swallow hole, August 1990-September 1991

\begin{tabular}{|c|c|c|c|c|c|c|c|}
\hline $\begin{array}{l}\text { Sample } \\
\text { Number }\end{array}$ & Date & Time (CST) & $\begin{array}{c}\text { Total Nitrate- } \\
\text { Nitrogen } \\
\text { (mg/L as N) }\end{array}$ & $\begin{array}{c}\text { Total Nitrite } \\
(\mathrm{mg} / \mathrm{L} \text { as } \\
\left.\mathrm{NO}_{2}{ }^{-}\right)\end{array}$ & $\begin{array}{c}\text { Ammonia } \\
(m g / L \text { as } \\
\left.\mathrm{NH}_{3}\right)\end{array}$ & $\begin{array}{c}\text { Total } \\
\text { Kjeldahl } \\
\text { Nitrogen } \\
(\mathrm{mg} / \mathrm{L} \text { as } \mathrm{N}) \\
\end{array}$ & $\begin{array}{l}\text { Orthophosphate } \\
\left(\mathrm{mg} / \mathrm{L}_{\text {as }} \mathrm{PO}_{4}^{-3}\right)\end{array}$ \\
\hline GDSW0001 & May/22/1991 & $10: 30$ & 6.70 & 0.058 & 0.050 & $<0.030$ & 0.040 \\
\hline GDSW0002 & Jun/26/1991 & $8: 50$ & 5.70 & 0.034 & 0.050 & $<0.030$ & 0.033 \\
\hline GDSW0003 & Jul/25/1991 & $8: 55$ & 4.30 & 0.171 & 0.120 & $<0.030$ & 0.074 \\
\hline & & Average* $^{*}$ & 5.57 & 0.088 & $\overline{0.073}$ & & 0.049 \\
\hline & & Maximum & 6.70 & 0.171 & 0.120 & $<0.030$ & 0.074 \\
\hline & & Minimum & 4.30 & 0.034 & 0.050 & & 0.033 \\
\hline
\end{tabular}

Pleasant Grove Spring, August 1990-September 1991

\begin{tabular}{|c|c|c|c|c|c|c|}
\hline $\begin{array}{l}\text { Sample } \\
\text { Number }\end{array}$ & $\begin{array}{c}\text { Laboratory } \\
\mathrm{pH}\end{array}$ & $\begin{array}{c}\text { Laboratory } \\
\text { Specific } \\
\text { Conductance } \\
\left(\text { at } 25^{\circ} \mathrm{C}\right)(\mu S)\end{array}$ & $\begin{array}{c}\text { Total Alkalinity } \\
\text { (mg/L as CaCO3) }\end{array}$ & $\begin{array}{c}\text { Dissolved } \\
\text { Solids Residue } \\
\text { on Evaporation } \\
\left(\mathrm{mg} / \mathrm{L} 180^{\circ} \mathrm{C}\right)\end{array}$ & $\begin{array}{c}\text { Suspended } \\
\text { Solids } \\
\text { Residue on } \\
\text { Evaporation } \\
(\mathrm{mg} / \mathrm{L} \\
\left.180^{\circ} \mathrm{C}\right)\end{array}$ & $\begin{array}{c}\text { Total Iron } \\
\text { (mg/L as Fe })\end{array}$ \\
\hline PGSP0001 & 7.16 & 468 & 219 & 278 & 5 & 0.106 \\
\hline PGSP0002 & 7.02 & 363 & 150 & 194 & 26 & 0.688 \\
\hline PGSP0003 & 7.15 & 397 & 174 & 256 & 9 & 0.128 \\
\hline PGSP0004 & 7.08 & 365 & 160 & 254 & 33 & 0.772 \\
\hline PGSP0005 & 6.98 & 357 & 154 & 230 & 18 & 1.230 \\
\hline PGSP0006 & 6.71 & 440 & 200 & 238 & 8 & 0.213 \\
\hline PGSP0007 & 6.48 & 481 & 224 & 310 & 3 & 0.058 \\
\hline PGSP0008 & 6.93 & 489 & 232 & 308 & 4 & 0.046 \\
\hline Average $^{*}$ & 6.94 & 420 & 189.13 & 259 & 13.25 & 0.405 \\
\hline Maximum & 7.16 & 489 & 232 & 310 & 33 & 1.230 \\
\hline Minimum & 6.48 & 357 & 150 & 194 & 3 & 0.046 \\
\hline Stand. Dev. & 0.23 & 56.0 & 33.61 & 39.5 & 11.21 & 0.439 \\
\hline Coef. Var & 0.03 & 0.1 & 0.18 & 0.2 & 0.85 & 1.083 \\
\hline
\end{tabular}

*These statistics are presented as a descriptive summary of the table. The effects of aliasing and variable sampling intervals may significantly affect the validity of averages presented as representative of ground-water quality in the basin. No data means an analysis was not performed. 
Spring Valley karst window, August 1990-September 1991

\begin{tabular}{|c|c|c|c|c|c|c|}
\hline $\begin{array}{l}\text { Sample } \\
\text { Number }\end{array}$ & $\begin{array}{l}\text { Laboratory } \\
\mathrm{pH}\end{array}$ & $\begin{array}{c}\text { Laboratory } \\
\text { Specific } \\
\text { Conductance } \\
\left(\text { at } 25^{\circ} \mathrm{C}\right)(\mu S)\end{array}$ & $\begin{array}{c}\text { Total Alkalinity } \\
\text { (mg/L as CaCO3) }\end{array}$ & $\begin{array}{c}\text { Dissolved } \\
\text { Solids Residue } \\
\text { on Evaporation } \\
\left(\mathrm{mg} / \mathrm{L} 180^{\circ} \mathrm{C}\right)\end{array}$ & $\begin{array}{c}\text { Suspended } \\
\text { Solids } \\
\text { Residue on } \\
\text { Evaporation } \\
(\mathrm{mg} / \mathrm{L} \\
\left.180^{\circ} \mathrm{C}\right)\end{array}$ & $\begin{array}{c}\text { Total Iron } \\
(m g / L \text { as } F e)\end{array}$ \\
\hline SVKW0001 & 7.12 & 466 & 218 & 283 & 4 & 0.134 \\
\hline SVKW0002 & 7.08 & 362 & 150 & 194 & 32 & 0.778 \\
\hline SVKW0003 & 7.18 & 369 & 162 & 252 & 40 & 1.100 \\
\hline SVKW0004 & 7.10 & 359 & 156 & 232 & 16 & 0.788 \\
\hline SVKW0005 & 6.73 & 441 & 199 & 250 & 8 & 0.279 \\
\hline SVKW0006 & 6.55 & 479 & 222 & 306 & 5 & 0.384 \\
\hline SVKW0007 & 6.93 & 489 & 231 & 284 & 5 & 0.194 \\
\hline Average* & 6.96 & 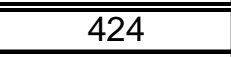 & 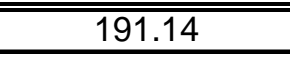 & 257 & 15.71 & 0.522 \\
\hline Maximum & 7.18 & 489 & 231 & 306 & 40 & 1.100 \\
\hline Minimum & 6.55 & 359 & 150 & 194 & 4 & 0.134 \\
\hline Stand. Dev. & 0.23 & 58.3 & 34.40 & 37.6 & 14.61 & 0.367 \\
\hline Coef. Var. & 0.03 & 0.1 & 0.18 & 0.1 & 0.93 & 0.702 \\
\hline
\end{tabular}

The Canyon karst window, August 1990-September 1991

\begin{tabular}{|c|c|c|c|c|c|c|}
\hline $\begin{array}{l}\text { Sample } \\
\text { Number }\end{array}$ & $\begin{array}{l}\text { Laboratory } \\
\mathrm{pH}\end{array}$ & $\begin{array}{c}\text { Laboratory } \\
\text { Specific } \\
\text { Conductance } \\
\left(\text { at } 25^{\circ} \mathrm{C}\right)(\mu S)\end{array}$ & $\begin{array}{l}\text { Total Alkalinity } \\
\text { (mg/L as CaCO3) }\end{array}$ & $\begin{array}{c}\text { Dissolved } \\
\text { Solids Residue } \\
\text { on Evaporation } \\
\text { ( } \mathrm{mg} / \mathrm{L} 180^{\circ} \mathrm{C} \text { ) }\end{array}$ & $\begin{array}{c}\text { Suspended } \\
\text { Solids } \\
\text { Residue on } \\
\text { Evaporation } \\
(\mathrm{mg} / \mathrm{L} \\
\left.180^{\circ} \mathrm{C}\right)\end{array}$ & $\begin{array}{c}\text { Total Iron } \\
(\mathrm{mg} / \mathrm{L} \text { as } \mathrm{Fe})\end{array}$ \\
\hline TCKW0001 & 7.11 & 450 & 212 & 276 & 16 & 0.558 \\
\hline TCKW0002 & 7.00 & 395 & 179 & 222 & 34 & 0.424 \\
\hline TCKW0003 & 6.99 & 367 & 168 & 214 & 94 & 2.650 \\
\hline TCKW0004 & 7.00 & 387 & 174 & 250 & 23 & 0.692 \\
\hline TCKW0005 & 6.71 & 427 & 194 & 238 & 24 & 0.600 \\
\hline TCKW0006 & 6.62 & 458 & 213 & 296 & 26 & 0.750 \\
\hline TCKW0007 & 7.03 & 467 & 221 & 276 & 56 & 2.430 \\
\hline Average* & 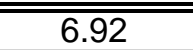 & 422 & 194.43 & 253 & 39.00 & $\bar{~} 1.158$ \\
\hline Maximum & 7.11 & 467 & 221 & 296 & 94 & 2.650 \\
\hline Minimum & 6.62 & 367 & 168 & 214 & 16 & 0.424 \\
\hline Stand. Dev. & 0.18 & 39.0 & 21.27 & 30.6 & 27.44 & 0.952 \\
\hline Coef. Var. & 0.03 & 0.1 & 0.11 & 0.1 & 0.70 & 0.822 \\
\hline
\end{tabular}

${ }^{*}$ These statistics are presented as a descriptive summary of the table. The effects of aliasing and variable sampling intervals may significantly affect the validity of averages presented as representative of ground-water quality in the basin. No data means an analysis was not performed. 
Shackelford Spring, August 1990-September 1991

\begin{tabular}{|c|c|c|c|c|c|c|}
\hline $\begin{array}{l}\text { Sample } \\
\text { Number }\end{array}$ & $\begin{array}{c}\text { Laboratory } \\
\mathrm{pH}\end{array}$ & $\begin{array}{c}\text { Laboratory } \\
\text { Specific } \\
\text { Conductance } \\
\left(\text { at } 25^{\circ} \mathrm{C}\right)(\mu \mathrm{S}) \\
\end{array}$ & $\begin{array}{c}\text { Total Alkalinity } \\
\text { (mg/L as CaCO3) }\end{array}$ & $\begin{array}{c}\text { Dissolved } \\
\text { Solids Residue } \\
\text { on Evaporation } \\
\left(\mathrm{mg} / \mathrm{L} 180^{\circ} \mathrm{C}\right) \\
\end{array}$ & $\begin{array}{l}\text { Suspended } \\
\text { Solids } \\
\text { Residue on } \\
\text { Evaporation } \\
(\mathrm{mg} / \mathrm{L} \\
\left.180^{\circ} \mathrm{C}\right) \\
\end{array}$ & $\begin{array}{c}\text { Total Iron } \\
(\mathrm{mg} / \mathrm{L} \text { as } \mathrm{Fe})\end{array}$ \\
\hline SKSP0001 & 7.20 & 443 & 212 & 299 & 4 & 0.147 \\
\hline SKSP0002 & 6.98 & 392 & 150 & 212 & 8 & 0.118 \\
\hline SKSP0003 & 7.09 & 407 & 163 & 264 & 6 & 0.123 \\
\hline SKSP0004 & 7.16 & 406 & 162 & 316 & 40 & 0.012 \\
\hline SKSP0005 & 6.88 & 433 & 168 & 296 & 7 & 0.303 \\
\hline SKSP0006 & 6.66 & 444 & 178 & 298 & 5 & 1.040 \\
\hline SKSP0007 & 7.08 & 444 & 184 & 270 & 27 & 0.388 \\
\hline Average* & $\overline{7.01}$ & 424 & 173.86 & 279 & 13.86 & 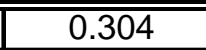 \\
\hline Maximum & 7.20 & 444 & 212 & 316 & 40 & 1.040 \\
\hline Minimum & 6.66 & 392 & 150 & 212 & 4 & 0.012 \\
\hline Stand. Dev. & 0.19 & 21.9 & 20.15 & 34.7 & 13.99 & 0.348 \\
\hline Coef. Var. & 0.03 & 0.1 & 0.12 & 0.1 & 1.01 & 1.143 \\
\hline
\end{tabular}

Thad Flowers blue hole, August 1990-September 1991

\begin{tabular}{|c|c|c|c|c|c|c|}
\hline $\begin{array}{l}\text { Sample } \\
\text { Number }\end{array}$ & $\begin{array}{l}\text { Laboratory } \\
\mathrm{pH}\end{array}$ & $\begin{array}{c}\text { Laboratory } \\
\text { Specific } \\
\text { Conductance } \\
\left(\text { at } 25^{\circ} \mathrm{C}\right)(\mu \mathrm{S})\end{array}$ & $\begin{array}{c}\text { Total Alkalinity } \\
\text { (mg/L as CaCO3) }\end{array}$ & $\begin{array}{c}\text { Dissolved } \\
\text { Solids Residue } \\
\text { on Evaporation } \\
\text { ( } \mathrm{mg} / \mathrm{L} 180^{\circ} \mathrm{C} \text { ) }\end{array}$ & $\begin{array}{c}\text { Suspended } \\
\text { Solids } \\
\text { Residue on } \\
\text { Evaporation } \\
(\mathrm{mg} / \mathrm{L} \\
\left.180^{\circ} \mathrm{C}\right)\end{array}$ & $\begin{array}{c}\text { Total Iron } \\
(m g / L \text { as } F e)\end{array}$ \\
\hline TFBH0001 & 6.92 & 360 & 129 & 202 & 3 & 0.014 \\
\hline TFBH0002 & 7.15 & 390 & 154 & 268 & 3 & 0.028 \\
\hline TFBH0003 & 7.02 & 382 & 150 & 304 & 4 & 0.126 \\
\hline TFBH0004 & 7.04 & 372 & 151 & 260 & 6 & 0.123 \\
\hline TFBH0005 & 7.12 & 437 & 203 & 232 & 8 & 1.010 \\
\hline TFBH0006 & 6.33 & 121 & 37 & 164 & 420 & \\
\hline Average* & 6.93 & 344 & 137.33 & 238 & 74.00 & 0.260 \\
\hline Maximum & 7.15 & 437 & 203 & 304 & 420 & 1.010 \\
\hline Minimum & 6.33 & 121 & 37 & 164 & 3 & 0.014 \\
\hline Stand. Dev & 0.30 & 112.2 & 54.91 & 50.1 & 169.52 & 0.422 \\
\hline Coef. Var. & 0.04 & 0.3 & 0.40 & 0.2 & 2.29 & 1.623 \\
\hline
\end{tabular}

*These statistics are presented as a descriptive summary of the table. The effects of aliasing and variable sampling intervals may significantly affect the validity of averages presented as representative of ground-water quality in the basin. No data means an analysis was not performed. 
George Delaney swallow hole, August 1990-September 1991

\begin{tabular}{|c|c|c|c|c|c|c|}
\hline $\begin{array}{l}\text { Sample } \\
\text { Number }\end{array}$ & $\begin{array}{c}\text { Laboratory } \\
\mathrm{pH}\end{array}$ & $\begin{array}{c}\text { Laboratory } \\
\text { Specific } \\
\text { Conductance } \\
\left(\text { at } 25^{\circ} \mathrm{C}\right)(\mu S)\end{array}$ & $\begin{array}{c}\text { Total Alkalinity } \\
\text { (mg/L as CaCO3) }\end{array}$ & $\begin{array}{c}\text { Dissolved } \\
\text { Solids Residue } \\
\text { on Evaporation } \\
\left(\mathrm{mg} / \mathrm{L} 180^{\circ} \mathrm{C}\right)\end{array}$ & $\begin{array}{c}\text { Suspended } \\
\text { Solids } \\
\text { Residue on } \\
\text { Evaporation } \\
(\mathrm{mg} / \mathrm{L} \\
\left.180^{\circ} \mathrm{C}\right)\end{array}$ & $\begin{array}{c}\text { Total Iron } \\
(m g / L \text { as } F e)\end{array}$ \\
\hline GDSW0001 & 7.60 & 385 & 154 & 308 & 16 & 0.146 \\
\hline GDSW0002 & 7.02 & 381 & 157 & 244 & 14 & 0.375 \\
\hline GDSW0003 & 7.48 & $\overline{411}$ & 177 & 268 & 36 & 1.390 \\
\hline Average $^{*}$ & $\overline{7.37}$ & $\overline{\overline{392}}$ & 162.67 & $\overline{273}$ & 22.00 & 0.637 \\
\hline Maximum & 7.60 & 411 & 177 & 308 & 36 & 1.390 \\
\hline Minimum & 7.02 & 381 & 154 & 244 & 14 & 0.146 \\
\hline
\end{tabular}

Pleasant Grove Spring, August 1990-September 1991

\begin{tabular}{|c|c|c|c|c|c|c|c|}
\hline $\begin{array}{l}\text { Sample } \\
\text { Number }\end{array}$ & $\begin{array}{c}\text { Total } \\
\text { Calcium } \\
\text { (mg/L as Ca) }\end{array}$ & $\begin{array}{c}\text { Total } \\
\text { Magnesium } \\
\text { (mg/L as Mg) }\end{array}$ & $\begin{array}{l}\text { Total Sodium } \\
\text { ( } \mathrm{mg} / \mathrm{L} \text { as } \mathrm{Na})\end{array}$ & $\begin{array}{c}\text { Total } \\
\text { Potassium } \\
\text { (mg/L as K) }\end{array}$ & $\begin{array}{c}\text { Bicarbonate } \\
(\mathrm{mg} / \mathrm{L} \text { as } \\
\left.\mathrm{HCO}_{3}{ }^{-}\right)\end{array}$ & $\begin{array}{c}\text { Total Sulfate } \\
\left(\mathrm{mg}^{\mathrm{L}} \mathrm{L} \text { as }\right. \\
\left.\mathrm{SO}_{4}^{-2}\right)\end{array}$ & $\begin{array}{l}\text { Dissolved } \\
\text { Chloride } \\
\text { (mg/L as Cl) }\end{array}$ \\
\hline PGSP0001 & 78.10 & 7.59 & 2.18 & 1.32 & 267 & 5.48 & 5.01 \\
\hline PGSP0002 & 62.90 & 5.57 & 2.08 & 1.66 & 183 & 5.00 & 6.13 \\
\hline PGSP0003 & 68.20 & 6.15 & 2.21 & 1.12 & 212 & 10.90 & 5.86 \\
\hline PGSP0004 & 65.60 & 5.93 & 2.11 & 1.26 & 195 & 5.62 & 5.18 \\
\hline PGSP0005 & 64.30 & 5.98 & 1.89 & 1.91 & 188 & 5.00 & 5.00 \\
\hline PGSP0006 & 76.60 & 7.40 & 2.18 & 1.17 & 244 & 5.40 & 5.28 \\
\hline PGSP0007 & 88.00 & 8.46 & 2.26 & 1.15 & 273 & 7.53 & 4.65 \\
\hline PGSP0008 & 85.90 & 8.37 & 2.17 & 1.22 & 283 & 5.82 & 4.33 \\
\hline Average* $^{*}$ & $\overline{73.70}$ & 6.93 & 2.14 & 1.35 & $\overline{230.63}$ & $\overline{6.34}$ & $\overline{5.18}$ \\
\hline \begin{tabular}{|l|} 
Maximum \\
\end{tabular} & 88.00 & 8.46 & 2.26 & 1.91 & 283 & 10.90 & 6.13 \\
\hline \begin{tabular}{|l|} 
Minimum \\
\end{tabular} & 62.90 & 5.57 & 1.89 & 1.12 & 183 & 5.00 & 4.33 \\
\hline Stand. Dev. & 9.87 & 1.16 & 0.11 & 0.28 & 40.96 & 2.01 & 0.59 \\
\hline Coef. Var. & 0.13 & 0.17 & 0.05 & 0.21 & 0.18 & 0.32 & 0.11 \\
\hline
\end{tabular}

*These statistics are presented as a descriptive summary of the table. The effects of aliasing and variable sampling intervals may significantly affect the validity of averages presented as representative of ground-water quality in the basin. No data means an analysis was not performed. 
Spring Valley karst window, August 1990-September 1991

\begin{tabular}{|c|c|c|c|c|c|c|c|}
\hline $\begin{array}{l}\text { Sample } \\
\text { Number }\end{array}$ & $\begin{array}{c}\text { Total } \\
\text { Calcium } \\
\text { (mg/L as Ca) }\end{array}$ & $\begin{array}{c}\text { Total } \\
\text { Magnesium } \\
\text { (mg/L as } M g)\end{array}$ & $\begin{array}{l}\text { Total Sodium } \\
\text { ( } \mathrm{mg} / \mathrm{L} \text { as } \mathrm{Na})\end{array}$ & $\begin{array}{c}\text { Total } \\
\text { Potassium } \\
\text { (mg/L as K) }\end{array}$ & $\begin{array}{c}\text { Bicarbonate } \\
\left(\mathrm{mg}^{\mathrm{L} \text { as }}\right. \\
\left.\mathrm{HCO}_{3}{ }^{-}\right)\end{array}$ & $\begin{array}{c}\text { Total Sulfate } \\
(\mathrm{mg} / \mathrm{L} \text { as } \\
\left.\mathrm{SO}_{4}^{-2}\right)\end{array}$ & $\begin{array}{l}\text { Dissolved } \\
\text { Chloride } \\
\text { (mg/L as Cl) }\end{array}$ \\
\hline SVKW0001 & 80.10 & 7.99 & 2.25 & 1.32 & 266 & 5.50 & 4.88 \\
\hline SVKW0002 & 63.50 & 5.68 & 2.10 & 1.43 & 183 & 5.00 & 5.94 \\
\hline SVKW0003 & 66.70 & 6.07 & 2.14 & 1.07 & 198 & 5.46 & 5.34 \\
\hline$\overline{\text { SVKW0004 }}$ & 64.40 & 6.05 & 1.95 & 1.51 & 190 & 5.00 & 5.12 \\
\hline SVKW0005 & 77.40 & 7.54 & 2.17 & 1.27 & 243 & 5.06 & 5.17 \\
\hline SVKW0006 & 85.70 & 8.50 & 2.20 & 1.11 & 271 & 5.00 & 4.62 \\
\hline SVKW0007 & 84.00 & 8.44 & 2.15 & 1.38 & 282 & 5.84 & 4.15 \\
\hline "Average* & $\overline{774.54}$ & $\overline{77.18}$ & $\overline{\overline{2.14}}$ & $\overline{c 1.30}$ & $\overline{2033.29}$ & "5.27 & $\overline{\overline{5.03}}$ \\
\hline Maximum & 85.70 & 8.50 & 2.25 & 1.51 & 282 & 5.84 & 5.94 \\
\hline \begin{tabular}{|l|} 
Minimum \\
\end{tabular} & 63.50 & 5.68 & 1.95 & 1.07 & 183 & 5.00 & 4.15 \\
\hline Stand. Dev. & 9.48 & 1.22 & 0.10 & 0.16 & 42.05 & 0.34 & 0.57 \\
\hline Coef. Var. & 0.13 & 0.17 & 0.04 & 0.12 & 0.18 & 0.06 & 0.11 \\
\hline
\end{tabular}

The Canyon karst window, August 1990-September 1991

\begin{tabular}{|c|c|c|c|c|c|c|c|}
\hline $\begin{array}{l}\text { Sample } \\
\text { Number }\end{array}$ & $\begin{array}{c}\text { Total } \\
\text { Calcium } \\
(\mathrm{mg} / \mathrm{L} \text { as } \mathrm{Ca})\end{array}$ & $\begin{array}{c}\text { Total } \\
\text { Magnesium } \\
\text { (mg/L as } M g)\end{array}$ & $\begin{array}{l}\text { Total Sodium } \\
\text { ( } \mathrm{mg} / \mathrm{L} \text { as } \mathrm{Na})\end{array}$ & $\begin{array}{c}\text { Total } \\
\text { Potassium } \\
\text { (mg/L as K) }\end{array}$ & $\begin{array}{c}\text { Bicarbonate } \\
\left(\mathrm{mg}^{\prime} \mathrm{L} \text { as }\right. \\
\left.\mathrm{HCO}_{3}^{-}\right)\end{array}$ & $\begin{array}{c}\text { Total Sulfate } \\
(\mathrm{mg} / \mathrm{L} \text { as } \\
\left.\mathrm{SO}_{4}^{-2}\right)\end{array}$ & $\begin{array}{l}\text { Dissolved } \\
\text { Chloride } \\
\text { (mg/L as Cl) }\end{array}$ \\
\hline TCKW0001 & 78.70 & 7.49 & 2.19 & 1.32 & 258 & 0.00 & 4.26 \\
\hline TCKW0002 & 70.70 & 6.06 & 1.98 & 1.15 & 218 & 9.06 & 4.82 \\
\hline TCKW0003 & 67.50 & 6.51 & 1.95 & 1.46 & 205 & 5.94 & 4.38 \\
\hline TCKW0004 & 73.40 & 6.18 & 1.99 & 1.28 & 212 & 5.00 & 4.77 \\
\hline TCKW0005 & 75.60 & 7.16 & 2.11 & 1.15 & 236 & 5.00 & 4.80 \\
\hline TCKW0006 & 85.00 & 8.17 & 2.24 & 1.31 & 260 & 5.00 & 4.42 \\
\hline TCKW0007 & 81.40 & 8.23 & 2.28 & 1.10 & 269 & 5.25 & 4.05 \\
\hline Average* $^{\star}$ & $\overline{766.04}$ & $\overline{77.11}$ & 2.11 & 1.25 & 236.86 & 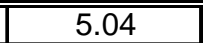 & $4 \quad 4.50$ \\
\hline Maximum & 85.00 & 8.23 & 2.28 & 1.46 & 269 & 9.06 & 4.82 \\
\hline Minimum & 67.50 & 6.06 & 1.95 & 1.10 & 205 & 0.00 & 4.05 \\
\hline Stand. Dev. & 6.12 & 0.90 & 0.13 & 0.13 & 25.84 & 2.66 & 0.30 \\
\hline Coef. Var. & 0.08 & 0.13 & 0.06 & 0.10 & 0.11 & 0.53 & 0.07 \\
\hline
\end{tabular}

\footnotetext{
*These statistics are presented as a descriptive summary of the table. The effects of aliasing and variable sampling intervals may significantly affect the validity of averages presented as representative of ground-water quality in the basin. No data means an analysis was not performed.
} 
Shackelford Spring, August 1990-September 1991

\begin{tabular}{|l|c|c|c|c|c|c|c|}
\hline $\begin{array}{c}\text { Sample } \\
\text { Number }\end{array}$ & $\begin{array}{c}\text { Total } \\
\text { Calcium } \\
(\mathrm{mg} / \mathrm{L} \text { as Ca) }\end{array}$ & $\begin{array}{c}\text { Total } \\
\text { Magnesium } \\
(\mathrm{mg} / \mathrm{L} \text { as } \mathrm{Mg})\end{array}$ & $\begin{array}{c}\text { Total Sodium } \\
(\mathrm{mg} / \mathrm{L} \text { as } \mathrm{Na})\end{array}$ & $\begin{array}{c}\text { Total } \\
\text { Potassium } \\
(\mathrm{mg} / \mathrm{L} \text { as } \mathrm{K})\end{array}$ & $\begin{array}{c}\text { Bicarbonate } \\
(\mathrm{mg} / \mathrm{L} \text { as } \\
\left.\mathrm{HCO}_{3}{ }^{-}\right)\end{array}$ & $\begin{array}{c}\text { Total Sulfate } \\
(\mathrm{mg} / \mathrm{L} \text { as } \\
\left.\mathrm{SO}_{4}^{-2}\right)\end{array}$ & $\begin{array}{c}\text { Dissolved } \\
\text { Chloride } \\
(\mathrm{mg} / \mathrm{L} \text { as Cl) }\end{array}$ \\
\hline SKSP0001 & 74.30 & 5.59 & 3.17 & 1.32 & 258 & 6.59 & 9.60 \\
\hline SKSP0002 & 69.10 & 5.45 & 2.66 & 1.30 & 182 & 5.69 & 7.74 \\
\hline SKSP0003 & 71.30 & 5.54 & 2.87 & 1.10 & 199 & 10.60 & 8.60 \\
\hline SKSP0004 & 72.40 & 5.65 & 2.88 & 0.93 & 198 & 7.11 & 8.67 \\
\hline SKSP0005 & 75.80 & 5.81 & 3.23 & 1.05 & 205 & 6.04 & 9.45 \\
\hline SKSP0006 & 77.70 & 5.99 & 3.08 & 1.07 & 217 & 12.60 & 9.53 \\
\hline SKSP0007 & 76.30 & 6.00 & 2.96 & 1.18 & 224 & 8.76 & 9.52 \\
\hline \hline Average & 73.84 & 5.72 & 2.98 & 1.14 & 211.86 & 8.20 & 9.02 \\
\hline Maximum & 77.70 & 6.00 & 3.23 & 1.32 & 258 & 12.60 & 9.60 \\
\hline Minimum & 69.10 & 5.45 & 2.66 & 0.93 & 182 & 5.69 & 7.74 \\
\hline Stand. Dev. & 3.05 & 0.22 & 0.20 & 0.14 & 24.49 & 2.59 & 0.70 \\
\hline Coef. Var. & 0.04 & 0.04 & 0.07 & 0.12 & 0.12 & 0.32 & 0.08 \\
\hline \hline Number of analyses 7
\end{tabular}

Thad Flowers blue hole, August 1990-September 1991

\begin{tabular}{|l|c|c|c|c|c|c|c|}
\hline $\begin{array}{c}\text { Sample } \\
\text { Number }\end{array}$ & $\begin{array}{c}\text { Total } \\
\text { Calcium } \\
(\mathrm{mg} / \mathrm{L} \text { as Ca) }\end{array}$ & $\begin{array}{c}\text { Total } \\
\text { Magnesium } \\
(\mathrm{mg} / \mathrm{L} \text { as } \mathrm{Mg})\end{array}$ & $\begin{array}{c}\text { Total Sodium } \\
(\mathrm{mg} / \mathrm{L} \text { as } \mathrm{Na})\end{array}$ & $\begin{array}{c}\text { Total } \\
\text { Potassium } \\
(\mathrm{mg} / \mathrm{L} \text { as } \mathrm{K})\end{array}$ & $\begin{array}{c}\text { Bicarbonate } \\
(\mathrm{mg} / \mathrm{L} \text { as } \\
\left.\mathrm{HCO}_{3}{ }^{-}\right)\end{array}$ & $\begin{array}{c}\text { Total Sulfate } \\
(\mathrm{mg} / \mathrm{L} \text { as } \\
\left.\mathrm{SO}_{4}^{-2}\right)\end{array}$ & $\begin{array}{c}\text { Dissolved } \\
\text { Chloride } \\
(\mathrm{mg} / \mathrm{L} \text { as Cl) }\end{array}$ \\
\hline TFBH0001 & 62.10 & 4.51 & 2.91 & 0.76 & 157 & 8.48 & 10.40 \\
\hline TFBH0002 & 67.20 & 4.73 & 3.19 & 0.66 & 188 & 15.30 & 10.80 \\
\hline TFBH0003 & 64.60 & 4.58 & 3.17 & 0.93 & 183 & 7.05 & 10.30 \\
\hline TFBH0004 & 68.80 & 4.77 & 3.10 & 1.60 & 184 & 7.14 & 9.52 \\
\hline TFBH0005 & 72.10 & 5.21 & 3.08 & 3.01 & 248 & 6.20 & 10.40 \\
\hline TFBH0006 & 1.00 & 1.00 & 1.00 & 1.00 & 45 & 14.40 & 2.00 \\
\hline \hline Average & 66.96 & 4.76 & 3.09 & 1.39 & 167.50 & 9.76 & 8.90 \\
\hline Maximum & 72.10 & 5.21 & 3.19 & 3.01 & 248 & 15.30 & 10.80 \\
\hline Minimum & 62.10 & 4.51 & 2.91 & 0.66 & 45 & 6.20 & 2.00 \\
\hline Stand. Dev. & 3.84 & 0.27 & 0.11 & 0.98 & 67.13 & 4.02 & 3.41 \\
\hline Coef. Var. & 0.06 & 0.06 & 0.04 & 0.70 & 0.40 & 0.41 & 0.38 \\
\hline \hline Number of analyses 6
\end{tabular}

George Delaney swallow hole, August 1990-September 1991

\begin{tabular}{|c|c|c|c|c|c|c|c|}
\hline $\begin{array}{l}\text { Sample } \\
\text { Number }\end{array}$ & $\begin{array}{c}\text { Total } \\
\text { Calcium } \\
(\mathrm{mg} / \mathrm{L} \text { as Ca })\end{array}$ & $\begin{array}{c}\text { Total } \\
\text { Magnesium } \\
\text { (mg/L as Mg) }\end{array}$ & $\begin{array}{l}\text { Total Sodium } \\
\text { ( } \mathrm{mg} / \mathrm{L} \text { as } \mathrm{Na})\end{array}$ & $\begin{array}{c}\text { Total } \\
\text { Potassium } \\
\text { (mg/L as K) }\end{array}$ & $\begin{array}{c}\text { Bicarbonate } \\
(\mathrm{mg} / \mathrm{L} \text { as } \\
\left.\mathrm{HCO}_{3}^{-}\right)\end{array}$ & $\begin{array}{c}\text { Total Sulfate } \\
(\mathrm{mg} / \mathrm{L} \text { as } \\
\left.\mathrm{SO}_{4}^{-2}\right)\end{array}$ & $\begin{array}{l}\text { Dissolved } \\
\text { Chloride } \\
\text { (mg/L as Cl) }\end{array}$ \\
\hline GDSW0001 & 68.20 & 5.36 & 3.04 & 0.93 & 188 & 6.48 & 8.45 \\
\hline GDSW0002 & 71.60 & 5.82 & 2.75 & 1.26 & 191 & 6.31 & 7.81 \\
\hline GDSW0003 & 71.50 & 6.45 & 2.75 & 1.81 & 216 & 6.01 & 8.04 \\
\hline Average* $^{*}$ & $\overline{70.43}$ & 5.88 & 2.85 & 1.33 & $\bar{~} 198.33$ & "6.27 & 8.10 \\
\hline Maximum & 71.60 & 6.45 & 3.04 & 1.81 & 216 & 6.48 & 8.45 \\
\hline \begin{tabular}{|l|} 
Minimum \\
\end{tabular} & 68.20 & 5.36 & 2.75 & 0.93 & 188 & 6.01 & 7.81 \\
\hline
\end{tabular}

\footnotetext{
*These statistics are presented as a descriptive summary of the table. The effects of aliasing and variable sampling intervals may significantly affect the validity of averages presented as representative of ground-water quality in the basin. No data means an analysis was not performed.
} 
Pleasant Grove Spring, October 1991-September 1992

\begin{tabular}{|c|c|c|c|c|c|c|c|}
\hline $\begin{array}{l}\text { Sample } \\
\text { Number }\end{array}$ & Date & Time (CST) & $\begin{array}{l}\text { Total Nitrate- } \\
\text { Nitrogen } \\
\text { (mg/L as N) }\end{array}$ & $\begin{array}{c}\text { Total Nitrite } \\
\left(\mathrm{mg} / \mathrm{L} \text { as } \mathrm{NO}_{2-}\right)\end{array}$ & $\begin{array}{c}\text { Ammonia } \\
\left(\mathrm{mg} / \mathrm{L} \text { as } \mathrm{NH}_{3}\right)\end{array}$ & $\begin{array}{l}\text { Total Kjeldahl } \\
\text { Nitrogen } \\
\text { (mg/L as } N) \\
\end{array}$ & \begin{tabular}{|c} 
Orthophosphate \\
$\left(\mathrm{mg}^{\prime} \mathrm{L}\right.$ as \\
$\left.\mathrm{PO}_{4}{ }^{-3}\right)$ \\
\end{tabular} \\
\hline PGSP0009 & Oct/22/1991 & $8: 50$ & 3.69 & & & & 0.037 \\
\hline PGSP0010 & Dec/17/1991 & $8: 06$ & 5.25 & & & & 0.049 \\
\hline PGSP0011 & Jan/29/1992 & $11: 00$ & 4.77 & & & & 0.030 \\
\hline PGSP0012 & Feb/26/1992 & $12: 15$ & 4.54 & & & & 0.034 \\
\hline PGSP0013 & Mar/25/1992 & $13: 20$ & 5.00 & & & & 0.027 \\
\hline PGSP0014 & Apr/01/1992 & $16: 16$ & 5.00 & & & & \\
\hline PGSP0015 & Apr/09/1992 & $15: 28$ & 4.75 & & & & \\
\hline PGSP0016 & Apr/16/1992 & $10: 30$ & 4.66 & & & & \\
\hline PGSP0017 & Apr/20/1992 & $18: 55$ & 4.66 & & & & \\
\hline PGSP0018 & Apr/21/1992 & $8: 30$ & 4.50 & & & & \\
\hline PGSP0019 & Apr/21/1992 & $17: 55$ & 4.54 & & & & \\
\hline PGSP0020 & Apr/22/1992 & $7: 37$ & 4.59 & & & & \\
\hline PGSP0021 & Apr/29/1992 & $9: 40$ & 4.38 & & & & 0.034 \\
\hline PGSP0022 & May/07/1992 & $12: 30$ & 4.32 & & & & \\
\hline PGSP0023 & May/14/1992 & $8: 30$ & 4.30 & & & & \\
\hline PGSP0024 & May/20/1992 & $7: 35$ & 5.79 & & & & \\
\hline PGSP0025 & May/20/1992 & $14: 30$ & & & & & \\
\hline PGSP0026 & May/27/1992 & $10: 45$ & 5.18 & & & & 0.035 \\
\hline PGSP0027 & Jun/03/1992 & $15: 45$ & 5.83 & & & & 0.049 \\
\hline PGSP0028 & Jun/04/1992 & $2: 58$ & 4.76 & & & & \\
\hline PGSP0029 & Jun/04/1992 & $3: 18$ & 4.71 & & & & \\
\hline PGSP0030 & Jun/04/1992 & $3: 38$ & 4.75 & & & & \\
\hline PGSP0031 & Jun/04/1992 & $3: 58$ & 4.77 & & & & \\
\hline PGSP0032 & Jun/04/1992 & $4: 18$ & 4.64 & & & & \\
\hline PGSP0033 & Jun/04/1992 & $4: 38$ & 4.24 & & & & \\
\hline PGSP0034 & 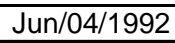 & 4:58 & 3.38 & & & & \\
\hline PGSP0035 & Jun/04/1992 & $5: 18$ & 3.72 & & & & \\
\hline PGSP0036 & Jun/04/1992 & $5: 38$ & 3.87 & & & & \\
\hline PGSP0037 & Jun/04/1992 & $5: 58$ & 3.96 & & & & \\
\hline PGSP0038 & $\begin{array}{l}\text { Jun/04/1992 } \\
\end{array}$ & $6: 58$ & 3.38 & & & & \\
\hline PGSP0039 & Jun/04/1992 & $7: 58$ & 3.80 & & & & \\
\hline PGSP0040 & Jun/04/1992 & $8: 58$ & 4.22 & & & & \\
\hline PGSP0041 & Jun/04/1992 & $9: 58$ & 4.42 & & & & \\
\hline PGSP0042 & Jun/04/1992 & $10: 58$ & 4.44 & & & & \\
\hline PGSP0043 & Jun/04/1992 & $11: 58$ & 4.67 & & & & \\
\hline PGSP0044 & Jun/04/1992 & $12: 58$ & 5.02 & & & & \\
\hline PGSP0045 & Jun/04/1992 & $13: 58$ & 5.10 & & & & \\
\hline PGSP0046 & Jun/04/1992 & $14: 58$ & 5.11 & & & & \\
\hline PGSP0047 & Jun/04/1992 & $15: 58$ & 4.80 & & & & \\
\hline PGSP0052 & Jun/04/1992 & $17: 15$ & & & & & \\
\hline PGSP0048 & Jun/04/1992 & 19:55 & 5.09 & & & & \\
\hline PGSP0049 & Jun/04/1992 & $23: 55$ & 5.25 & & & & \\
\hline PGSP0050 & Jun/05/1992 & $3: 55$ & 5.37 & & & & \\
\hline PGSP0051 & Jun/05/1992 & $7: 55$ & 5.52 & & & & \\
\hline PGSP0053 & Jun/10/1992 & $13: 20$ & 5.03 & & & & \\
\hline PGSP0054 & Jun/18/1992 & $9: 30$ & 4.59 & & & & 0.050 \\
\hline PGSP0055 & Jun/24/1992 & $13: 35$ & 4.84 & & & & \\
\hline PGSP0056 & Jul/01/1992 & $15: 00$ & 4.84 & & & & \\
\hline
\end{tabular}

*These statistics are presented as a descriptive summary of the table. The effects of aliasing and variable sampling intervals may significantly affect the validity of averages presented as representative of ground-water quality in the basin. No data means an analysis was not performed. 
Pleasant Grove Spring, October 1991-September 1992

\begin{tabular}{|c|c|c|c|c|c|c|c|}
\hline $\begin{array}{l}\text { Sample } \\
\text { Number }\end{array}$ & Date & Time (CST) & $\begin{array}{l}\text { Total Nitrate- } \\
\text { Nitrogen } \\
\text { (mg/L as } N)\end{array}$ & $\begin{array}{c}\text { Total Nitrite } \\
\left(\mathrm{mg} / \mathrm{L} \text { as } \mathrm{NO}_{2-}\right)\end{array}$ & $\begin{array}{c}\text { Ammonia } \\
\left(\mathrm{mg} / \mathrm{L} \text { as } \mathrm{NH}_{3}\right)\end{array}$ & $\begin{array}{l}\text { Total Kjeldahl } \\
\text { Nitrogen } \\
\text { (mg/L as } N)\end{array}$ & $\begin{array}{c}\text { Orthophosphate } \\
\text { (mg/L as } \\
\left.\mathrm{PO}_{4}{ }^{-3}\right)\end{array}$ \\
\hline PGSP0057 & Jul/08/1992 & $11: 15$ & 4.66 & & & & \\
\hline PGSP0058 & Jul/13/1992 & $15: 00$ & 4.66 & & & & \\
\hline PGSP0059 & Jul/23/1992 & $15: 45$ & 4.70 & & & & \\
\hline PGSP0060 & Jul/30/1992 & $6: 55$ & 6.62 & & & & \\
\hline PGSP0061 & Aug/13/1992 & $14: 15$ & 4.61 & & & & \\
\hline PGSP0062 & Aug/26/1992 & $11: 30$ & 6.22 & & & & 0.039 \\
\hline PGSP0063 & Sep/09/1992 & $11: 42$ & 4.48 & & & & \\
\hline PGSP0064 & Sep/23/1992 & $14: 25$ & 4.00 & & & & \\
\hline & & Average* & 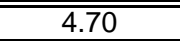 & & & & 0.038 \\
\hline & & Maximum & 6.62 & & & & 0.050 \\
\hline & & Minimum & 3.38 & & & & 0.027 \\
\hline & & Stand. Dev. & 0.62 & & & & 0.008 \\
\hline & & Coef. Var. & 0.13 & & & & 0.215 \\
\hline
\end{tabular}

\begin{tabular}{|c|c|c|c|c|c|c|c|}
\hline $\begin{array}{l}\text { Sample } \\
\text { Number }\end{array}$ & Date & Time (CST) & $\begin{array}{l}\text { Total Nitrate- } \\
\text { Nitrogen } \\
\text { (mg/L as } N)\end{array}$ & $\begin{array}{c}\text { Total Nitrite } \\
\left(\mathrm{mg} / \mathrm{L} \text { as } \mathrm{NO}_{2-}\right)\end{array}$ & $\begin{array}{c}\text { Ammonia } \\
\left(\mathrm{mg} / \mathrm{L} \text { as } \mathrm{NH}_{3}\right)\end{array}$ & $\begin{array}{c}\text { Total Kjeldahl } \\
\text { Nitrogen } \\
\text { (mg/L as } N)\end{array}$ & $\begin{array}{c}\text { Orthophosphate } \\
\text { (mg/L as } \\
\left.\mathrm{PO}_{4}^{-3}\right)\end{array}$ \\
\hline SVKW0008 & Oct/22/1991 & $8: 00$ & 3.44 & & & & 0.043 \\
\hline SVKW0009 & Jan/29/1992 & $10: 00$ & 4.79 & & & & 0.027 \\
\hline SVKW0010 & \begin{tabular}{|l|}
$\mathrm{Feb} / 26 / 1992$ \\
\end{tabular} & $11: 00$ & 4.72 & & & & 0.030 \\
\hline SVKW0011 & Mar/25/1992 & $10: 55$ & 5.13 & & & & 0.027 \\
\hline SVKW0012 & Apr/01/1992 & $15: 15$ & 5.02 & & & & \\
\hline SVKW0013 & \begin{tabular}{|l|} 
Apr/29/1992 \\
\end{tabular} & $8: 40$ & 4.52 & & & & 0.039 \\
\hline SVKW0014 & May/27/1992 & $9: 15$ & 5.40 & & & & 0.033 \\
\hline & & Average* $^{\star}$ & 4.72 & & & & 0.033 \\
\hline & & Maximum & 5.40 & & & & 0.043 \\
\hline & & Minimum & 3.44 & & & & 0.027 \\
\hline & & Stand. Dev. & 0.63 & & & & 0.007 \\
\hline & & Coef. Var. & 0.13 & & & & 0.199 \\
\hline
\end{tabular}

The Canyon karst window, October 1991-September 1992

\begin{tabular}{|c|c|c|c|c|c|c|c|}
\hline $\begin{array}{l}\text { Sample } \\
\text { Number }\end{array}$ & Date & Time (CST) & $\begin{array}{l}\text { Total Nitrate- } \\
\text { Nitrogen } \\
\text { (mg/L as N) }\end{array}$ & $\begin{array}{c}\text { Total Nitrite } \\
\left(\mathrm{mg} / \mathrm{L} \text { as } \mathrm{NO}_{2-}\right)\end{array}$ & $\begin{array}{c}\text { Ammonia } \\
\left(\mathrm{mg} / \mathrm{L} \text { as } \mathrm{NH}_{3}\right)\end{array}$ & $\begin{array}{c}\text { Total Kjeldahl } \\
\text { Nitrogen } \\
\text { (mg/L as } N)\end{array}$ & $\begin{array}{c}\text { Orthophosphate } \\
\text { (mg/L as } \\
\mathrm{PO}_{4}^{-3} \text { ) }\end{array}$ \\
\hline TCKW0008 & $\mathrm{Dec} / 17 / 1991$ & $11: 30$ & 4.00 & & & & 0.040 \\
\hline TCKW0009 & Jan/29/1992 & $8: 30$ & 4.09 & & & & 0.031 \\
\hline TCKW0010 & Feb/26/1992 & $9: 45$ & 3.80 & & & & 0.026 \\
\hline TCKW0011 & Mar/25/1992 & $12: 00$ & 3.98 & & & & 0.032 \\
\hline TCKW0012 & Apr/01/1992 & $14: 45$ & 3.89 & & & & \\
\hline TCKW0013 & Apr/29/1992 & $7: 40$ & 3.98 & & & & 0.032 \\
\hline TCKW0014 & May/27/1992 & $10: 05$ & 5.02 & & & & 0.030 \\
\hline & & Average $^{*}$ & 4.11 & & & & 0.032 \\
\hline & & Maximum & 5.02 & & & & 0.040 \\
\hline & & Minimum & 3.80 & & & & 0.026 \\
\hline & & Stand. Dev. & 0.41 & & & & 0.005 \\
\hline & & Coef. Var. & 0.10 & & & & 0.144 \\
\hline
\end{tabular}

${ }^{*}$ These statistics are presented as a descriptive summary of the table. The effects of aliasing and variable sampling intervals may significantly affect the validity of averages presented as representative of ground-water quality in the basin. No data means an analysis was not performed. 
Shackelford Spring, October 1991-September 1992

\begin{tabular}{|c|c|c|c|c|c|c|c|}
\hline $\begin{array}{l}\text { Sample } \\
\text { Number }\end{array}$ & Date & Time (CST) & $\begin{array}{l}\text { Total Nitrate- } \\
\text { Nitrogen } \\
\text { (mg/L as } N)\end{array}$ & $\begin{array}{c}\text { Total Nitrite } \\
\left(\mathrm{mg} / \mathrm{L} \text { as } \mathrm{NO}_{2-}\right)\end{array}$ & $\begin{array}{c}\text { Ammonia } \\
\left(m g / L \text { as } \mathrm{NH}_{3}\right)\end{array}$ & $\begin{array}{c}\text { Total Kjeldahl } \\
\text { Nitrogen } \\
\text { (mg/L as } N)\end{array}$ & $\begin{array}{c}\text { Orthophosphate } \\
(\mathrm{mg} / \mathrm{L} \text { as } \\
\left.\mathrm{PO}_{4}^{-3}\right)\end{array}$ \\
\hline SKSP0008 & Oct/22/1991 & $6: 34$ & 6.52 & & & & 0.035 \\
\hline SKSP0009 & $\mathrm{Dec} / 17 / 1991$ & $12: 00$ & 7.44 & & & & 0.042 \\
\hline SKSP0010 & Jan/29/1992 & $14: 30$ & 7.41 & & & & 0.028 \\
\hline SKSP0011 & Feb/26/1992 & $8: 40$ & 7.57 & & & & 0.028 \\
\hline SKSP0012 & Mar/25/1992 & $8: 40$ & 7.10 & & & & 0.028 \\
\hline SKSP0013 & Apr/29/1992 & $6: 43$ & 7.19 & & & & 0.027 \\
\hline SKSP0014 & May/27/1992 & $11: 50$ & 8.50 & & & & 0.033 \\
\hline \multicolumn{3}{|r|}{ Average* $^{\star}$} & 7.39 & & & & 0.032 \\
\hline \multicolumn{3}{|r|}{ Maximum } & 8.50 & & & & 0.042 \\
\hline \multicolumn{3}{|r|}{ Minimum } & 6.52 & & & & 0.027 \\
\hline \multicolumn{3}{|r|}{ Stand. Dev. } & 0.60 & & & & 0.006 \\
\hline \multicolumn{3}{|r|}{ Coef. Var. } & 0.08 & & & & 0.174 \\
\hline
\end{tabular}

Thad Flowers blue hole, October 1991-September 1992

\begin{tabular}{|c|c|c|c|c|c|c|c|}
\hline $\begin{array}{l}\text { Sample } \\
\text { Number }\end{array}$ & Date & Time (CST) & $\begin{array}{l}\text { Total Nitrate- } \\
\text { Nitrogen } \\
\text { (mg/L as } N)\end{array}$ & $\begin{array}{c}\text { Total Nitrite } \\
\left(\mathrm{mg} / \mathrm{L} \text { as } \mathrm{NO}_{2-}\right)\end{array}$ & $\begin{array}{c}\text { Ammonia } \\
\left(\mathrm{mg} / \mathrm{L} \text { as } \mathrm{NH}_{3}\right)\end{array}$ & $\begin{array}{l}\text { Total Kjeldahl } \\
\text { Nitrogen } \\
\text { (mg/L as } N)\end{array}$ & $\begin{array}{c}\text { Orthophosphate } \\
(\mathrm{mg} / \mathrm{L} \text { as } \\
\left.\mathrm{PO}_{4}^{-3}\right)\end{array}$ \\
\hline TFBH0007 & $\mathrm{Dec} / 17 / 1991$ & $13: 30$ & 8.46 & & & & 0.035 \\
\hline TFBH0008 & Jan/29/1992 & $7: 50$ & 7.23 & & & & 0.026 \\
\hline TFBH0009 & Feb/26/1992 & $7: 30$ & 3.10 & & & & 0.016 \\
\hline TFBH0010 & Mar/25/1992 & $7: 20$ & 7.03 & & & & 0.018 \\
\hline \multicolumn{3}{|r|}{ Average $^{*}$} & 6.45 & & & & 0.024 \\
\hline \multicolumn{3}{|r|}{ Maximum } & 8.46 & & & & 0.035 \\
\hline \multicolumn{3}{|r|}{ Minimum } & 3.10 & & & & 0.016 \\
\hline \multicolumn{3}{|r|}{ Stand. Dev. } & 2.33 & & & & 0.009 \\
\hline \multicolumn{3}{|r|}{ Coef. Var. } & 0.36 & & & & 0.364 \\
\hline
\end{tabular}

George Delaney swallow hole, October 1991-September 1992

\begin{tabular}{|c|c|c|c|c|c|c|c|}
\hline $\begin{array}{l}\text { Sample } \\
\text { Number }\end{array}$ & Date & Time (CST) & $\begin{array}{c}\text { Total Nitrate- } \\
\text { Nitrogen } \\
\text { (mg/L as } N)\end{array}$ & $\begin{array}{c}\text { Total Nitrite } \\
\left(\mathrm{mg} / \mathrm{L} \text { as } \mathrm{NO}_{2-}\right)\end{array}$ & $\begin{array}{c}\text { Ammonia } \\
\left(\mathrm{mg} / \mathrm{L} \text { as } \mathrm{NH}_{3}\right)\end{array}$ & $\begin{array}{c}\text { Total Kjeldahl } \\
\text { Nitrogen } \\
\text { (mg/L as } N) \\
\end{array}$ & $\begin{array}{c}\text { Orthophosphate } \\
(\mathrm{mg} / \mathrm{L} \text { as } \\
\left.\mathrm{PO}_{4}^{-3}\right)\end{array}$ \\
\hline GDSW0004 & Dec/17/1991 & $10: 00$ & 7.15 & & & & 0.051 \\
\hline GDSW0005 & Jan/29/1992 & $9: 10$ & 6.69 & & & & 0.018 \\
\hline GDSW0006 & Feb/26/1992 & $10: 20$ & 6.80 & & & & 0.072 \\
\hline GDSW0007 & Mar/25/1992 & 9:45 & 6.94 & & & & 0.018 \\
\hline \begin{tabular}{|l|} 
GDSW0008 \\
\end{tabular} & Apr/01/1992 & 15:45 & 6.80 & & & & \\
\hline & & Average* $^{\star}$ & 6.88 & & & & 0.040 \\
\hline & & Maximum & 7.15 & & & & 0.072 \\
\hline & & Minimum & 6.69 & & & & 0.018 \\
\hline & & Stand. Dev. & 0.18 & & & & 0.027 \\
\hline & & Coef. Var. & 0.03 & & & & 0.668 \\
\hline
\end{tabular}

*These statistics are presented as a descriptive summary of the table. The effects of aliasing and variable sampling intervals may significantly affect the validity of averages presented as representative of ground-water quality in the basin. No data means an analysis was not performed. 
Pleasant Grove Spring, October 1991-September 1992

\begin{tabular}{|c|c|c|c|c|c|c|}
\hline $\begin{array}{l}\text { Sample } \\
\text { Number }\end{array}$ & $\begin{array}{l}\text { Laboratory } \\
\mathrm{pH}\end{array}$ & $\begin{array}{c}\text { Laboratory } \\
\text { Specific } \\
\text { Conductance } \\
\left(\text { at } 25^{\circ} \mathrm{C}\right)(\mu S)\end{array}$ & $\begin{array}{c}\text { Total Alkalinity } \\
\text { (mg/L as CaCO3) }\end{array}$ & $\begin{array}{c}\text { Dissolved } \\
\text { Solids Residue } \\
\text { on Evaporation } \\
\left(\mathrm{mg} / \mathrm{L} 180^{\circ} \mathrm{C}\right)\end{array}$ & $\begin{array}{l}\text { Suspended } \\
\text { Solids } \\
\text { Residue on } \\
\text { Evaporation } \\
(\mathrm{mg} / \mathrm{L} \\
\left.180^{\circ} \mathrm{C}\right)\end{array}$ & $\begin{array}{c}\text { Total Iron } \\
(\mathrm{mg} / \mathrm{L} \text { as } \mathrm{Fe})\end{array}$ \\
\hline PGSP0009 & 6.90 & 490 & 238 & 274 & 3 & 0.061 \\
\hline PGSP0010 & 7.00 & 384 & 165 & 218 & 37 & 1.350 \\
\hline PGSP0011 & 7.30 & 427 & 190 & 218 & 4 & 0.071 \\
\hline PGSP0012 & 7.12 & 429 & 196 & 280 & 6 & 0.406 \\
\hline PGSP0013 & 6.63 & 393 & 175 & 254 & 9 & 0.178 \\
\hline PGSP0021 & 6.30 & 425 & 196 & 246 & 3 & 0.075 \\
\hline PGSP0026 & 7.22 & 434 & 201 & 286 & 3 & 0.224 \\
\hline PGSP0027 & 7.09 & 418 & 189 & 270 & 4 & 0.358 \\
\hline PGSP0028 & & & & 268 & 8 & \\
\hline PGSP0029 & & & & 304 & 35 & \\
\hline PGSP0030 & & & & 322 & 34 & \\
\hline PGSP0031 & & & & 290 & 114 & \\
\hline PGSP0032 & & & & 300 & 186 & \\
\hline PGSP0033 & & & & 242 & 370 & \\
\hline PGSP0034 & & & & 190 & 667 & \\
\hline PGSP0035 & & & & 242 & 311 & \\
\hline PGSP0036 & & & & 254 & 249 & \\
\hline PGSP0037 & & & & 268 & 289 & \\
\hline PGSP0038 & & & & 248 & 597 & \\
\hline PGSP0039 & & & & 326 & 294 & \\
\hline PGSP0040 & & & & 328 & 302 & \\
\hline PGSP0041 & & & & 322 & 196 & \\
\hline PGSP0042 & & & & 294 & 122 & \\
\hline PGSP0043 & & & & 260 & 116 & \\
\hline PGSP0044 & & & & 272 & 101 & \\
\hline PGSP0045 & & & & 260 & 128 & \\
\hline PGSP0046 & & & & 262 & 113 & \\
\hline PGSP0047 & & & & 234 & 115 & \\
\hline PGSP0048 & & & & 224 & 99 & \\
\hline PGSP0049 & & & & 208 & 62 & \\
\hline PGSP0050 & & & & 216 & 45 & \\
\hline PGSP0051 & & & & 232 & 35 & \\
\hline PGSP0054 & 6.74 & 414 & 186 & 262 & 3 & 0.257 \\
\hline PGSP0057 & & & & 274 & 11 & \\
\hline PGSP0058 & & & & 250 & 4 & \\
\hline PGSP0062 & 7.01 & 476 & 225 & 280 & 3 & 0.018 \\
\hline Average* & $\overline{6.93}$ & $\overline{429}$ & $\overline{196.10}$ & 263 & $\overline{129.94}$ & 0.300 \\
\hline Maximum & 7.30 & 490 & 238 & 328 & 667 & 1.350 \\
\hline Minimum & 6.30 & 384 & 165 & 190 & 3 & 0.018 \\
\hline Stand. Dev. & 0.30 & 32.7 & 21.65 & 34.3 & 163.72 & 0.391 \\
\hline Coef. Var. & 0.04 & 0.1 & 0.11 & 0.1 & 1.26 & 1.306 \\
\hline
\end{tabular}

*These statistics are presented as a descriptive summary of the table. The effects of aliasing and variable sampling intervals may significantly affect the validity of averages presented as representative of ground-water quality in the basin. No data means an analysis was not performed. 
Spring Valley karst window, October 1991-September 1992

\begin{tabular}{|l|c|c|c|c|c|c|}
\hline $\begin{array}{c}\text { Sample } \\
\text { Number }\end{array}$ & $\begin{array}{c}\text { Laboratory } \\
\mathrm{pH}\end{array}$ & $\begin{array}{c}\text { Laboratory } \\
\text { Specific } \\
\text { Conductance } \\
(\text { at 25 } \mathrm{C})(\mu \mathrm{S})\end{array}$ & $\begin{array}{c}\text { Total Alkalinity } \\
(\mathrm{mg} / \mathrm{L} \text { as CaCO3) }\end{array}$ & $\begin{array}{c}\text { Suspended } \\
\text { Solids } \\
\text { Solids Residue } \\
\text { on Evaporation } \\
\left(\mathrm{mg} / \mathrm{L} 180^{\circ} \mathrm{C}\right)\end{array}$ & $\begin{array}{c}\text { Residue on } \\
\text { Evaporation } \\
(\mathrm{mg} / \mathrm{L} \\
\left.180^{\circ} \mathrm{C}\right)\end{array}$ & $\begin{array}{c}\text { Total Iron } \\
(\mathrm{mg} / \mathrm{L} \text { as } \mathrm{Fe})\end{array}$ \\
\hline SVKW0008 & 6.75 & 492 & 237 & 272 & 3 & 0.067 \\
\hline SVKW0009 & 7.29 & 427 & 190 & 230 & 5 & 0.119 \\
\hline SVKW0010 & 7.13 & 430 & 195 & 286 & 6 & 0.283 \\
\hline SVKW0011 & 6.55 & 395 & 175 & 256 & 12 & 0.241 \\
\hline SVKW0013 & 6.15 & 431 & 197 & 242 & 6 & 0.093 \\
\hline SVKW0014 & 7.19 & 433 & 202 & 280 & 3 & 0.207 \\
\hline \hline Average & 6.84 & 435 & 199.33 & 261 & 5.83 & 0.168 \\
\hline Maximum & 7.29 & 492 & 237 & 286 & 12 & 0.283 \\
\hline Minimum & 6.15 & 395 & 175 & 230 & 3 & 0.067 \\
\hline Stand. Dev. & 0.44 & 31.5 & 20.64 & 22.2 & 3.31 & 0.088 \\
\hline Coef. Var. & 0.06 & 0.1 & 0.10 & 0.1 & 0.57 & 0.520 \\
\hline \hline
\end{tabular}

The Canyon karst window, October 1991-September 1992

\begin{tabular}{|l|c|c|c|c|c|c|}
\hline $\begin{array}{c}\text { Sample } \\
\text { Number }\end{array}$ & $\begin{array}{c}\text { Laboratory } \\
\mathrm{pH}\end{array}$ & $\begin{array}{c}\text { Laboratory } \\
\text { Specific } \\
\text { Conductance } \\
\left(\text { at } 25^{\circ} \mathrm{C}\right)(\mu \mathrm{S})\end{array}$ & $\begin{array}{c}\text { Total Alkalinity } \\
(\mathrm{mg} / \mathrm{L} \text { as CaCO3) }\end{array}$ & $\begin{array}{c}\text { Suspended } \\
\text { Solids Residue } \\
\text { on Evaporation } \\
\left(\mathrm{mg} / \mathrm{L} 180^{\circ} \mathrm{C}\right)\end{array}$ & $\begin{array}{c}\text { Sissolved } \\
\text { Residue on } \\
\text { Evaporation } \\
(\mathrm{mg} / \mathrm{L} \\
\left.180^{\circ} \mathrm{C}\right)\end{array}$ & $\begin{array}{c}\text { Total Iron } \\
(\mathrm{mg} / \mathrm{L} \text { as } \mathrm{Fe})\end{array}$ \\
\hline TCKW0008 & 6.87 & 389 & 177 & 226 & 20 & 0.993 \\
\hline TCKW0009 & 7.12 & 425 & 194 & 236 & 22 & 0.680 \\
\hline TCKW0010 & 6.98 & 431 & 205 & 260 & 16 & 0.489 \\
\hline TCKW0011 & 6.56 & 392 & 184 & 252 & 36 & 0.964 \\
\hline TCKW0013 & 5.99 & 424 & 200 & 256 & 17 & 0.445 \\
\hline TCKW0014 & 7.07 & 427 & 202 & 268 & 8 & 0.630 \\
\hline \hline Average ${ }^{*}$ & 6.77 & 415 & 193.67 & 250 & 19.83 & 0.700 \\
\hline Maximum & 7.12 & 431 & 205 & 268 & 36 & 0.933 \\
\hline Minimum & 5.99 & 389 & 177 & 226 & 8 & 0.445 \\
\hline Stand. Dev. & 0.43 & 18.9 & 11.04 & 15.7 & 9.26 & 0.233 \\
\hline Coef. Var. & 0.06 & \multicolumn{7}{|l|}{0.06} & 0.1 & 0.47 & 0.332 \\
\hline \hline
\end{tabular}

*These statistics are presented as a descriptive summary of the table. The effects of aliasing and variable sampling intervals may significantly affect the validity of averages presented as representative of ground-water quality in the basin. No data means an analysis was not performed. 
Shackelford Spring, October 1991-September 1992

\begin{tabular}{|c|c|c|c|c|c|c|}
\hline $\begin{array}{l}\text { Sample } \\
\text { Number }\end{array}$ & $\begin{array}{l}\text { Laboratory } \\
\mathrm{pH}\end{array}$ & $\begin{array}{c}\text { Laboratory } \\
\text { Specific } \\
\text { Conductance } \\
\left(\text { at } 25^{\circ} \mathrm{C}\right)(\mu S)\end{array}$ & $\begin{array}{c}\text { Total Alkalinity } \\
\text { (mg/L as CaCO3) }\end{array}$ & $\begin{array}{c}\text { Dissolved } \\
\text { Solids Residue } \\
\text { on Evaporation } \\
\text { ( } \mathrm{mg} / \mathrm{L} 180^{\circ} \mathrm{C} \text { ) }\end{array}$ & $\begin{array}{l}\text { Suspended } \\
\text { Solids } \\
\text { Residue on } \\
\text { Evaporation } \\
(\mathrm{mg} / \mathrm{L} \\
\left.180^{\circ} \mathrm{C}\right)\end{array}$ & $\begin{array}{c}\text { Total Iron } \\
\text { (mg/L as Fe })\end{array}$ \\
\hline SKSP0008 & 6.75 & 450 & 190 & 256 & 4 & 0.272 \\
\hline SKSP0009 & 7.06 & 423 & 170 & 244 & 14 & 0.365 \\
\hline SKSP0010 & 7.27 & 429 & 171 & 238 & 5 & 0.184 \\
\hline SKSP0011 & 7.11 & 428 & 171 & 316 & 6 & 0.184 \\
\hline \begin{tabular}{|l|} 
SKSP0012 \\
\end{tabular} & 6.57 & 413 & 170 & 298 & 4 & 0.126 \\
\hline SKSP0013 & 6.09 & 418 & 169 & 268 & 4 & 0.204 \\
\hline SKSP0014 & 7.29 & 427 & 173 & 288 & 6 & 0.167 \\
\hline Average $^{*}$ & 6.88 & 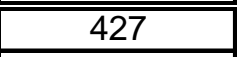 & 173.43 & 273 & $\overline{6.14}$ & 0.215 \\
\hline Maximum & 7.29 & 450 & 190 & 316 & 14 & 0.365 \\
\hline \begin{tabular}{|l|} 
Minimum \\
\end{tabular} & 6.09 & 413 & 169 & 238 & 4 & 0.126 \\
\hline Stand. Dev. & 0.44 & 11.7 & 7.41 & 29.1 & 3.58 & 0.080 \\
\hline Coef. Var. & 0.06 & & 0.04 & 0.1 & 0.58 & 0.371 \\
\hline
\end{tabular}

Thad Flowers blue hole, October 1991-September 1992

\begin{tabular}{|c|c|c|c|c|c|c|}
\hline $\begin{array}{l}\text { Sample } \\
\text { Number }\end{array}$ & $\begin{array}{c}\text { Laboratory } \\
\mathrm{pH}\end{array}$ & $\begin{array}{c}\text { Laboratory } \\
\text { Specific } \\
\text { Conductance } \\
\left(\text { at } 25^{\circ} \mathrm{C}\right)(\mu S)\end{array}$ & $\begin{array}{c}\text { Total Alkalinity } \\
\text { (mg/L as CaCO3) }\end{array}$ & $\begin{array}{l}\text { Dissolved } \\
\text { Solids Residue } \\
\text { on Evaporation } \\
\left(\mathrm{mg} / \mathrm{L} 180^{\circ} \mathrm{C}\right)\end{array}$ & $\begin{array}{l}\text { Suspended } \\
\text { Solids } \\
\text { Residue on } \\
\text { Evaporation } \\
(\mathrm{mg} / \mathrm{L} \\
\left.180^{\circ} \mathrm{C}\right)\end{array}$ & $\begin{array}{c}\text { Total Iron } \\
(\mathrm{mg} / \mathrm{L} \text { as } \mathrm{Fe})\end{array}$ \\
\hline TFBH0007 & 7.09 & 365 & 133 & 202 & 18 & 0.367 \\
\hline TFBH0008 & 7.71 & 402 & 152 & 218 & 20 & 0.494 \\
\hline TFBH0009 & 7.63 & 365 & 152 & 226 & 34 & 0.616 \\
\hline TFBH0010 & 6.50 & 362 & 137 & 250 & 4 & 0.047 \\
\hline Average* $^{*}$ & 7.23 & $\overline{374}$ & 143.50 & 224 & 19.00 & 0.381 \\
\hline Maximum & 7.71 & 402 & 152 & 250 & 34 & 0.616 \\
\hline Minimum & 6.50 & 362 & 133 & 202 & 4 & 0.047 \\
\hline Stand. Dev. & 0.56 & 19.1 & 9.95 & 20.0 & 12.27 & 0.245 \\
\hline Coef. Var. & 0.08 & 0.1 & 0.07 & 0.1 & 0.65 & 0.642 \\
\hline
\end{tabular}

*These statistics are presented as a descriptive summary of the table. The effects of aliasing and variable sampling intervals may significantly affect the validity of averages presented as representative of ground-water quality in the basin. No data means an analysis was not performed. 
George Delaney swallow hole, October 1991-September 1992

\begin{tabular}{|c|c|c|c|c|c|c|}
\hline $\begin{array}{l}\text { Sample } \\
\text { Number }\end{array}$ & $\begin{array}{l}\text { Laboratory } \\
\mathrm{pH}\end{array}$ & $\begin{array}{c}\text { Laboratory } \\
\text { Specific } \\
\text { Conductance } \\
\left(\text { at } 25^{\circ} \mathrm{C}\right)(\mu S) \text {. }\end{array}$ & $\begin{array}{c}\text { Total Alkalinity } \\
\text { (mg/L as CaCO3) }\end{array}$ & $\begin{array}{c}\text { Dissolved } \\
\text { Solids Residue } \\
\text { on Evaporation } \\
\left(\mathrm{mg} / \mathrm{L} 180^{\circ} \mathrm{C}\right)\end{array}$ & $\begin{array}{c}\text { Suspended } \\
\text { Solids } \\
\text { Residue on } \\
\text { Evaporation } \\
\quad(\mathrm{mg} / \mathrm{L} \\
\left.180^{\circ} \mathrm{C}\right)\end{array}$ & $\begin{array}{c}\text { Total Iron } \\
(\mathrm{mg} / \mathrm{L} \text { as } \mathrm{Fe})\end{array}$ \\
\hline GDSW0004 & 7.46 & 386 & 149 & 216 & 12 & 0.395 \\
\hline GDSW0005 & 7.68 & 418 & 168 & 218 & 8 & 0.168 \\
\hline GDSW0006 & 7.62 & 408 & 164 & 305 & 22 & 0.420 \\
\hline GDSW0007 & 7.00 & 389 & 156 & 274 & 14 & 0.230 \\
\hline Average* $^{\star}$ & $\overline{7.44}$ & 400 & 159.25 & 253 & 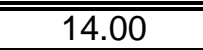 & 0.303 \\
\hline \begin{tabular}{|l|} 
Maximum \\
\end{tabular} & 7.68 & 418 & 168 & 305 & 22 & 0.420 \\
\hline \begin{tabular}{|l|} 
Minimum \\
\end{tabular} & 7.00 & 386 & 149 & 216 & 8 & 0.168 \\
\hline Stand. Dev. & 0.31 & 15.3 & 8.46 & 43.7 & 5.89 & 0.123 \\
\hline Coef. Var. & 0.04 & & 0.05 & 0.2 & 0.42 & 0.407 \\
\hline
\end{tabular}

Pleasant Grove Spring, October 1991-September 1992

\begin{tabular}{|c|c|c|c|c|c|c|c|}
\hline $\begin{array}{l}\text { Sample } \\
\text { Number }\end{array}$ & $\begin{array}{c}\text { Total } \\
\text { Calcium } \\
(\mathrm{mg} / \mathrm{L} \text { as } \mathrm{Ca}) \\
\end{array}$ & $\begin{array}{c}\text { Total } \\
\text { Magnesium } \\
(\mathrm{mg} / \mathrm{L} \text { as } \mathrm{Mg})\end{array}$ & $\begin{array}{l}\text { Total Sodium } \\
\text { (mg/L as Na) }\end{array}$ & $\begin{array}{c}\text { Total } \\
\text { Potassium } \\
\text { (mg/L as K) }\end{array}$ & $\begin{array}{c}\text { Bicarbonate } \\
(\mathrm{mg} / \mathrm{L} \text { as } \\
\left.\mathrm{HCO}_{3}^{-}\right)\end{array}$ & $\begin{array}{c}\text { Total Sulfate } \\
\left(\mathrm{mg}_{\mathrm{L}} \mathrm{L} \text { as }\right. \\
\left.\mathrm{SO}_{4}^{-2}\right)\end{array}$ & $\begin{array}{l}\text { Dissolved } \\
\text { Chloride } \\
\text { (mg/L as Cl) }\end{array}$ \\
\hline PGSP0009 & 88.90 & 8.85 & 2.24 & 0.93 & 290 & 6.24 & 4.13 \\
\hline PGSP0010 & 76.90 & 6.58 & 2.46 & 1.77 & 201 & 5.60 & 5.83 \\
\hline PGSP0011 & 76.30 & 6.96 & 2.33 & 0.92 & 232 & 5.53 & 10.30 \\
\hline PGSP0012 & 79.00 & 7.21 & 2.48 & 1.62 & 239 & 6.02 & 6.22 \\
\hline PGSP0013 & 70.70 & 6.17 & 2.40 & 1.20 & 213 & 5.26 & 6.41 \\
\hline PGSP0021 & 78.90 & 7.38 & 2.37 & 1.42 & 239 & 5.18 & 4.87 \\
\hline PGSP0026 & 79.90 & 7.66 & 2.32 & 1.31 & 245 & 5.66 & 5.26 \\
\hline PGSP0027 & 75.70 & 6.99 & 2.21 & 1.23 & 230 & 5.14 & 5.29 \\
\hline PGSP0054 & 69.90 & 6.55 & 2.18 & 0.72 & 227 & 5.26 & 4.56 \\
\hline PGSP0062 & 83.40 & 8.23 & 3.10 & 0.72 & 274 & 5.54 & 5.91 \\
\hline \begin{tabular}{|l} 
Average* \\
\end{tabular} & 77.96 & 7.26 & 2.41 & 1.18 & 239.00 & 5.54 & 5.88 \\
\hline Maximum & 88.90 & 8.85 & 3.10 & 1.77 & 290 & 6.24 & 10.30 \\
\hline \begin{tabular}{|l|} 
Minimum \\
\end{tabular} & 69.90 & 6.17 & 2.18 & 0.72 & 201 & 5.14 & 4.13 \\
\hline Stand. Dev. & 5.59 & 0.81 & 0.26 & 0.36 & 26.36 & 0.36 & 1.72 \\
\hline $\begin{array}{l}\text { Coef. Var. } \\
\end{array}$ & 0.07 & 0.11 & 0.11 & 0.30 & 0.11 & 0.07 & 0.29 \\
\hline
\end{tabular}

*These statistics are presented as a descriptive summary of the table. The effects of aliasing and variable sampling intervals may significantly affect the validity of averages presented as representative of ground-water quality in the basin. No data means an analysis was not performed. 
Spring Valley karst window, October 1991-September 1992

\begin{tabular}{|l|c|c|c|c|c|c|c|}
\hline $\begin{array}{c}\text { Sample } \\
\text { Number }\end{array}$ & $\begin{array}{c}\text { Total } \\
\text { Calcium } \\
(\mathrm{mg} / \mathrm{L} \text { as Ca } \mathrm{Ca}\end{array}$ & $\begin{array}{c}\text { Total } \\
\text { Magnesium } \\
(\mathrm{mg} / \mathrm{L} \text { as } \mathrm{Mg})\end{array}$ & $\begin{array}{c}\text { Total Sodium } \\
(\mathrm{mg} / \mathrm{L} \text { as } \mathrm{Na})\end{array}$ & $\begin{array}{c}\text { Total } \\
\text { Potassium } \\
(\mathrm{mg} / \mathrm{L} \text { as } \mathrm{K})\end{array}$ & $\begin{array}{c}\text { Bicarbonate } \\
(\mathrm{mg} / \mathrm{L} \text { as } \\
\left.\mathrm{HCO}_{3}{ }^{-}\right)\end{array}$ & $\begin{array}{c}\text { Total Sulfate } \\
(\mathrm{mg} / \mathrm{L} \text { as } \\
\left.\mathrm{SO}_{4}^{-2}\right)\end{array}$ & $\begin{array}{c}\text { Dissolved } \\
\text { Chloride } \\
(\mathrm{mg} / \mathrm{L} \text { as } \mathrm{Cl})\end{array}$ \\
\hline SVKW0008 & 89.30 & 9.11 & 2.26 & 0.94 & 289 & 6.54 & 4.92 \\
\hline SVKW0009 & 75.10 & 6.97 & 2.31 & 1.14 & 232 & 5.18 & 6.22 \\
\hline SVKW0010 & 78.40 & 7.21 & 2.48 & 1.33 & 238 & 6.27 & 6.53 \\
\hline SVKW0011 & 70.60 & 6.22 & 2.44 & 0.96 & 213 & 5.34 & 6.66 \\
\hline SVKW0013 & 78.10 & 7.41 & 2.31 & 1.11 & 240 & 5.24 & 5.04 \\
\hline SVKW0014 & 80.30 & 7.83 & 2.35 & 1.24 & 246 & 5.68 & 5.38 \\
\hline \hline Average* & 78.63 & 7.46 & 2.36 & 1.12 & 243.00 & 5.71 & 5.79 \\
\hline Maximum & 89.30 & 9.11 & 2.48 & 1.33 & 289 & 6.54 & 6.66 \\
\hline Minimum & 70.60 & 6.22 & 2.26 & 0.94 & 213 & 5.18 & 4.92 \\
\hline Stand. Dev. & 6.23 & 0.97 & 0.08 & 0.15 & 25.22 & 0.57 & 0.77 \\
\hline Coef. Var. & 0.08 & 0.13 & 0.04 & 0.14 & 0.10 & 0.10 & 0.13 \\
\hline \hline
\end{tabular}

The Canyon karst window, October 1991-September 1992

\begin{tabular}{|l|c|c|c|c|c|c|c|}
\hline $\begin{array}{c}\text { Sample } \\
\text { Number }\end{array}$ & $\begin{array}{c}\text { Total } \\
\text { Calcium } \\
(\mathrm{mg} / \mathrm{L} \text { as Ca })\end{array}$ & $\begin{array}{c}\text { Total } \\
\text { Magnesium } \\
(\mathrm{mg} / \mathrm{L} \text { as } \mathrm{Mg})\end{array}$ & $\begin{array}{c}\text { Total Sodium } \\
(\mathrm{mg} / \mathrm{L} \text { as } \mathrm{Na})\end{array}$ & $\begin{array}{c}\text { Total } \\
\text { Potassium } \\
(\mathrm{mg} / \mathrm{L} \text { as } \mathrm{K})\end{array}$ & $\begin{array}{c}\text { Bicarbonate } \\
(\mathrm{mg} / \mathrm{L} \text { as } \\
\left.\mathrm{HCO}_{3}{ }^{-}\right)\end{array}$ & $\begin{array}{c}\text { Total Sulfate } \\
(\mathrm{mg} / \mathrm{L} \text { as } \\
\left.\mathrm{SO}_{4}{ }^{-2}\right)\end{array}$ & $\begin{array}{c}\text { Dissolved } \\
\text { Chloride } \\
(\mathrm{mg} / \mathrm{L} \text { as Cl) }\end{array}$ \\
\hline TCKW0008 & 73.60 & 6.17 & 1.94 & 1.37 & 216 & 5.26 & 4.34 \\
\hline TCKW0009 & 77.00 & 6.81 & 2.15 & 1.15 & 236 & 5.00 & 5.11 \\
\hline TCKW0010 & 79.70 & 6.92 & 2.18 & 1.51 & 250 & 5.07 & 4.11 \\
\hline TCKW0011 & 71.40 & 6.18 & 2.02 & 1.42 & 224 & 5.00 & 4.82 \\
\hline TCKW0013 & 80.10 & 7.26 & 2.29 & 1.17 & 244 & 5.00 & 4.25 \\
\hline TCKW0014 & 78.20 & 7.14 & 2.16 & 1.48 & 246 & 5.00 & 4.36 \\
\hline \hline Average* & 76.67 & 6.75 & 2.12 & 1.35 & 236.00 & 5.06 & 4.50 \\
\hline Maximum & 80.10 & 7.26 & 2.29 & 1.51 & 250 & 5.26 & 5.11 \\
\hline Minimum & 71.40 & 6.17 & 1.94 & 1.15 & 216 & 5.00 & 4.11 \\
\hline Stand. Dev. & 3.48 & 0.47 & 0.12 & 0.16 & 13.45 & 0.10 & 0.38 \\
\hline Coef. Var. & 0.05 & 0.07 & 0.06 & 0.11 & 0.06 & 0.02 & 0.09 \\
\hline \hline
\end{tabular}

*These statistics are presented as a descriptive summary of the table. The effects of aliasing and variable sampling intervals may significantly affect the validity of averages presented as representative of ground-water quality in the basin. No data means an analysis was not performed. 
Shackelford Spring, October 1991-September 1992

\begin{tabular}{|c|c|c|c|c|c|c|c|}
\hline $\begin{array}{l}\text { Sample } \\
\text { Number }\end{array}$ & $\begin{array}{c}\text { Total } \\
\text { Calcium } \\
\text { (mg/L as Ca) }\end{array}$ & $\begin{array}{c}\text { Total } \\
\text { Magnesium } \\
\text { (mg/L as } M g)\end{array}$ & $\begin{array}{l}\text { Total Sodium } \\
\text { (mg/L as Na) }\end{array}$ & $\begin{array}{c}\text { Total } \\
\text { Potassium } \\
\text { (mg/L as K) }\end{array}$ & $\begin{array}{c}\text { Bicarbonate } \\
\left(\mathrm{mg} / \mathrm{L} \text { as }^{-}\right. \\
\left.\mathrm{HCO}_{3}{ }^{-}\right)\end{array}$ & $\begin{array}{c}\text { Total Sulfate } \\
\left(\mathrm{mg}_{\mathrm{L}} \text { as }\right. \\
\left.\mathrm{SO}_{4}^{-2}\right)\end{array}$ & $\begin{array}{l}\text { Dissolved } \\
\text { Chloride } \\
\text { (mg/L as Cl) }\end{array}$ \\
\hline SKSP0008 & 78.00 & 6.02 & 3.04 & 0.93 & 232 & 7.40 & 9.29 \\
\hline \begin{tabular}{|l|} 
SKSP0009 \\
\end{tabular} & 75.90 & 5.90 & 2.85 & 1.39 & 207 & 6.80 & 8.05 \\
\hline SKSP0010 & 76.60 & 5.85 & 3.02 & 1.18 & 208 & 6.44 & 9.72 \\
\hline SKSP0011 & 77.00 & 5.90 & 3.14 & 1.35 & 208 & 7.47 & 9.96 \\
\hline \begin{tabular}{|l|l|} 
SKSP012 \\
\end{tabular} & 75.80 & 5.85 & 2.95 & 1.20 & 207 & 6.47 & 8.81 \\
\hline \begin{tabular}{|l|l|} 
SKSP0013 \\
\end{tabular} & 76.10 & 5.81 & 3.03 & 1.15 & 206 & 6.33 & 8.80 \\
\hline SKSP0014 & 75.20 & 5.84 & 3.20 & 1.04 & 211 & 7.32 & 10.00 \\
\hline$\overline{\text { Average }}^{\star}$ & $\overline{776.37}$ & (5.88 & (3.03 & (1.18 & $\overline{211.29}$ & (26.89 & 9.23 \\
\hline \begin{tabular}{|l|} 
Maximum \\
\end{tabular} & 78.00 & 6.02 & 3.20 & 1.39 & 232 & 7.47 & 10.00 \\
\hline Minimum & 75.20 & 5.81 & 2.85 & 0.93 & 206 & 6.33 & 8.05 \\
\hline Stand. Dev. & 0.92 & 0.07 & 0.12 & 0.16 & 9.27 & 0.50 & 0.72 \\
\hline Coef. Var. & 0.01 & 0.01 & 0.04 & 0.14 & 0.04 & 0.07 & 0.08 \\
\hline
\end{tabular}

Thad Flowers blue hole, October 1991-September 1992

\begin{tabular}{|l|c|c|c|c|c|c|c|}
\hline $\begin{array}{c}\text { Sample } \\
\text { Number }\end{array}$ & $\begin{array}{c}\text { Total } \\
\text { Calcium } \\
(\mathrm{mg} / \mathrm{L} \text { as } \mathrm{Ca})\end{array}$ & $\begin{array}{c}\text { Total } \\
\text { Magnesium } \\
(\mathrm{mg} / \mathrm{L} \text { as } \mathrm{Mg})\end{array}$ & $\begin{array}{c}\text { Total Sodium } \\
(\mathrm{mg} / \mathrm{L} \text { as } \mathrm{Na})\end{array}$ & $\begin{array}{c}\text { Total } \\
\text { Potassium } \\
(\mathrm{mg} / \mathrm{L} \text { as } \mathrm{K})\end{array}$ & $\begin{array}{c}\text { Bicarbonate } \\
(\mathrm{mg} / \mathrm{L} \text { as } \\
\left.\mathrm{HCO}_{3}{ }^{-}\right)\end{array}$ & $\begin{array}{c}\text { Total Sulfate } \\
(\mathrm{mg} / \mathrm{L} \text { as } \\
\left.\mathrm{SO}_{4}^{-2}\right)\end{array}$ & $\begin{array}{c}\text { Dissolved } \\
\text { Chloride } \\
(\mathrm{mg} / \mathrm{L} \text { as Cl) }\end{array}$ \\
\hline TFBH0007 & 65.60 & 4.63 & 2.84 & 0.93 & 162 & 5.51 & 11.00 \\
\hline TFBH0008 & 71.50 & 5.03 & 3.20 & 0.95 & 185 & 6.83 & 12.80 \\
\hline TFBH0009 & 67.00 & 5.25 & 3.20 & 1.35 & 185 & 8.98 & 12.80 \\
\hline TFBH0010 & 63.30 & 4.60 & 3.01 & 0.72 & 167 & 7.87 & 11.00 \\
\hline \hline Average* & 66.85 & 4.88 & 3.06 & 0.99 & 174.75 & 7.30 & 11.90 \\
\hline Maximum & 71.50 & 5.25 & 3.20 & 1.35 & 185 & 8.98 & 12.80 \\
\hline Minimum & 63.30 & 4.60 & 2.84 & 0.72 & 162 & 5.51 & 11.00 \\
\hline Stand. Dev. & 3.45 & 0.32 & 0.17 & 0.26 & 12.01 & 1.48 & 1.04 \\
\hline Coef. Var. & 0.05 & 0.06 & 0.06 & 0.27 & 0.07 & 0.20 & 0.09 \\
\hline
\end{tabular}

George Delaney swallow hole, October 1991-September 1992

\begin{tabular}{|c|c|c|c|c|c|c|c|}
\hline $\begin{array}{l}\text { Sample } \\
\text { Number }\end{array}$ & $\begin{array}{c}\text { Total } \\
\text { Calcium } \\
(\mathrm{mg} / \mathrm{L} \text { as } \mathrm{Ca})\end{array}$ & $\begin{array}{c}\text { Total } \\
\text { Magnesium } \\
\text { (mg/L as Mg) }\end{array}$ & $\begin{array}{l}\text { Total Sodium } \\
\text { ( } \mathrm{mg} / \mathrm{L} \text { as } \mathrm{Na})\end{array}$ & $\begin{array}{c}\text { Total } \\
\text { Potassium } \\
\text { (mg/L as K) }\end{array}$ & $\begin{array}{c}\text { Bicarbonate } \\
(\mathrm{mg} / \mathrm{L} \text { as } \\
\left.\mathrm{HCO}_{3}{ }^{-}\right)\end{array}$ & $\begin{array}{c}\text { Total Sulfate } \\
(\mathrm{mg} / \mathrm{L} \text { as } \\
\left.\mathrm{SO}_{4}^{-2}\right)\end{array}$ & $\begin{array}{l}\text { Dissolved } \\
\text { Chloride } \\
\text { (mg/L as Cl) }\end{array}$ \\
\hline GDSW0004 & 66.50 & 5.21 & 2.94 & 1.68 & 182 & 7.51 & 9.76 \\
\hline GDSW0005 & 71.50 & 6.04 & 3.18 & 1.06 & 205 & 6.72 & 10.10 \\
\hline GDSW0006 & 71.60 & 5.67 & 3.63 & 2.19 & 200 & 8.61 & 10.20 \\
\hline GDSW0007 & 68.90 & 5.38 & 3.18 & 0.88 & 190 & 6.82 & 9.82 \\
\hline "Average* & "69.63 & $\overline{5.58}$ & 3.23 & 1.45 & $\overline{194.25}$ & $\overline{77.42}$ & 9.97 \\
\hline \begin{tabular}{|l|} 
Maximum \\
\end{tabular} & 71.60 & 6.04 & 3.63 & 2.19 & 205 & 8.61 & 10.20 \\
\hline Minimum & 66.50 & 5.21 & 2.94 & 0.88 & 182 & 6.72 & 9.76 \\
\hline Stand. Dev. & 2.43 & 0.36 & 0.29 & 0.60 & 10.28 & 0.87 & 0.21 \\
\hline Coef. Var. & 0.03 & 0.07 & 0.09 & 0.41 & 0.05 & 0.12 & 0.02 \\
\hline
\end{tabular}

*These statistics are presented as a descriptive summary of the table. The effects of aliasing and variable sampling intervals may significantly affect the validity of averages presented as representative of ground-water quality in the basin. No data means an analysis was not performed. 
Pleasant Grove Spring, October 1992-September 1993

\begin{tabular}{|c|c|c|c|c|c|c|c|}
\hline $\begin{array}{l}\text { Sample } \\
\text { Number }\end{array}$ & Date & Time (CST) & $\begin{array}{l}\text { Total Nitrate- } \\
\text { Nitrogen } \\
\text { (mg/L as N) }\end{array}$ & $\begin{array}{c}\text { Total Nitrite } \\
\left(\mathrm{mg} / \mathrm{L} \text { as } \mathrm{NO}_{2}^{-}\right)\end{array}$ & $\begin{array}{c}\text { Ammonia } \\
\left(\mathrm{mg} / \mathrm{L} \text { as } \mathrm{NH}_{3}\right)\end{array}$ & $\begin{array}{c}\text { Total Kjeldahl } \\
\text { Nitrogen } \\
\text { (mg/L as } N \text { ) }\end{array}$ & $\begin{array}{l}\text { Orthophosphate } \\
\left(\mathrm{mg} / \mathrm{L}_{\text {as } \mathrm{PO}_{4}}{ }^{-3}\right)\end{array}$ \\
\hline PGSP0065 & Oct/06/1992 & $12: 50$ & 4.29 & & & & 0.033 \\
\hline PGSP0066 & Oct/22/1992 & $10: 14$ & 4.00 & & & & \\
\hline PGSP0067 & Nov/06/1992 & $9: 00$ & 3.84 & & & & 0.044 \\
\hline PGSP0068 & Nov/20/1992 & $11: 54$ & 3.96 & & & & \\
\hline PGSP0070 & $\mathrm{Dec} / 03 / 1992$ & $9: 07$ & 4.02 & & & & 0.083 \\
\hline PGSP0071 & Jan/08/1993 & $10: 19$ & 5.18 & & & & 0.045 \\
\hline PGSP0072 & Jan/13/1993 & 8:00 & 5.29 & & & & \\
\hline PGSP0073 & Jan/13/1993 & 9:00 & 5.56 & & & & \\
\hline PGSP0074 & Jan/13/1993 & $10: 00$ & 5.51 & & & & \\
\hline PGSP0075 & Jan/13/1993 & $11: 00$ & 5.49 & & & & \\
\hline PGSP0076 & Jan/13/1993 & $12: 00$ & 5.44 & & & & \\
\hline PGSP0077 & Jan/13/1993 & 13:00 & 5.38 & & & & \\
\hline PGSP0078 & Jan/13/1993 & $14: 00$ & 5.47 & & & & \\
\hline PGSP0079 & Jan/13/1993 & $15: 00$ & 5.40 & & & & \\
\hline PGSP0080 & Jan/13/1993 & $16: 00$ & 5.42 & & & & \\
\hline PGSP0081 & $\mathrm{Jan} / 13 / 1993$ & 17:00 & 5.40 & & & & \\
\hline PGSP0082 & $\mathrm{Jan} / 21 / 1993$ & $10: 15$ & 5.33 & & & & \\
\hline PGSP0083 & $\mathrm{Jan} / 28 / 1993$ & 15:06 & 5.54 & & & & \\
\hline PGSP0084 & $\mathrm{Jan} / 28 / 1993$ & $15: 40$ & 5.33 & & & & \\
\hline PGSP0089 & Jan/28/1993 & $20: 40$ & 5.40 & & & & \\
\hline PGSP0095 & Jan/29/1993 & $2: 40$ & 5.45 & & & & \\
\hline PGSP0101 & Jan/29/1993 & $8: 40$ & 5.40 & & & & \\
\hline PGSP0107 & Jan/29/1993 & $14: 40$ & 5.38 & & & & \\
\hline PGSP0108 & Feb/04/1993 & $10: 00$ & 5.24 & & & & 0.045 \\
\hline PGSP0109 & Feb/16/1993 & $6: 10$ & 4.97 & & & & \\
\hline PGSP0110 & $\mathrm{Feb} / 16 / 1993$ & $6: 30$ & 5.02 & & & & \\
\hline PGSP0111 & Feb/16/1993 & $6: 50$ & 4.93 & & & & \\
\hline PGSP0112 & Feb/16/1993 & $7: 10$ & 4.95 & & & & \\
\hline PGSP0113 & $\mathrm{Feb} / 16 / 1993$ & $7: 30$ & 4.95 & & & & \\
\hline PGSP0114 & Feb/16/1993 & $7: 50$ & 4.93 & & & & \\
\hline PGSP0115 & $\mathrm{Feb} / 16 / 1993$ & $8: 10$ & 5.11 & & & & \\
\hline PGSP0116 & Feb/16/1993 & $8: 30$ & 5.04 & & & & \\
\hline PGSP0117 & Feb/16/1993 & $8: 50$ & 4.93 & & & & \\
\hline PGSP0118 & $\mathrm{Feb} / 16 / 1993$ & $9: 10$ & 5.02 & & & & \\
\hline PGSP0119 & Feb/16/1993 & $10: 10$ & 4.84 & & & & \\
\hline PGSP0120 & Feb/16/1993 & $11: 10$ & 4.97 & & & & \\
\hline PGSP0121 & $\mathrm{Feb} / 16 / 1993$ & $12: 10$ & 4.84 & & & & \\
\hline PGSP0122 & Feb/16/1993 & $13: 10$ & 5.02 & & & & \\
\hline PGSP0123 & $\mathrm{Feb} / 16 / 1993$ & $14: 10$ & 4.88 & & & & \\
\hline PGSP0124 & $\mathrm{Feb} / 16 / 1993$ & $15: 10$ & 4.97 & & & & \\
\hline PGSP0125 & $\mathrm{Feb} / 16 / 1993$ & $16: 10$ & 5.00 & & & & \\
\hline PGSP0126 & $\mathrm{Feb} / 16 / 1993$ & $17: 10$ & 5.00 & & & & \\
\hline PGSP0127 & $\mathrm{Feb} / 16 / 1993$ & $18: 10$ & 5.06 & & & & \\
\hline PGSP0128 & $\mathrm{Feb} / 16 / 1993$ & $19: 10$ & 5.00 & & & & \\
\hline PGSP0129 & $\mathrm{Feb} / 16 / 1993$ & $23: 10$ & 4.90 & & & & \\
\hline PGSP0130 & Feb/17/1993 & $3: 10$ & 4.68 & & & & \\
\hline PGSP0131 & Feb/17/1993 & $7: 10$ & 4.88 & & & & \\
\hline PGSP0132 & Feb/17/1993 & $11: 10$ & 5.06 & & & & \\
\hline PGSP0133 & Feb/17/1993 & $16: 30$ & 5.29 & & & & \\
\hline PGSP0134 & Feb/18/1993 & $8: 00$ & 5.42 & & & & \\
\hline PGSP0135 & Feb/21/1993 & $10: 13$ & 5.15 & & & & \\
\hline PGSP0136 & Feb/21/1993 & $10: 33$ & 5.02 & & & & \\
\hline PGSP0137 & Feb/21/1993 & $10: 53$ & 5.13 & & & & \\
\hline PGSP0138 & $\mathrm{Feb} / 21 / 1993$ & $11: 13$ & 5.11 & & & & \\
\hline
\end{tabular}

*These statistics are presented as a descriptive summary of the table. The effects of aliasing and variable sampling intervals may significantly affect the validity of averages presented as representative of ground-water quality in the basin. No data means an analysis was not performed. 
Pleasant Grove Spring, October 1992-September 1993

\begin{tabular}{|c|c|c|c|c|c|c|c|}
\hline $\begin{array}{l}\text { Sample } \\
\text { Number }\end{array}$ & Date & Time (CST) & $\begin{array}{l}\text { Total Nitrate- } \\
\text { Nitrogen } \\
\text { (mg/L as N) }\end{array}$ & $\begin{array}{c}\text { Total Nitrite } \\
\left(\mathrm{mg} / \mathrm{L} \text { as } \mathrm{NO}_{2}{ }^{-}\right)\end{array}$ & $\begin{array}{c}\text { Ammonia } \\
\left(\mathrm{mg} / \mathrm{L} \text { as } \mathrm{NH}_{3}\right)\end{array}$ & $\begin{array}{c}\text { Total Kjeldahl } \\
\text { Nitrogen } \\
\text { (mg/L as } N)\end{array}$ & $\begin{array}{l}\text { Orthophosphate } \\
\left(\mathrm{mg} / \mathrm{L}_{\text {as }} \mathrm{PO}_{4}^{-3}\right)\end{array}$ \\
\hline PGSP0139 & Feb/21/1993 & $11: 33$ & 4.97 & & & & \\
\hline PGSP0140 & Feb/21/1993 & $11: 53$ & 4.95 & & & & \\
\hline PGSP0141 & Feb/21/1993 & $12: 13$ & 5.00 & & & & \\
\hline PGSP0142 & Feb/21/1993 & $12: 33$ & 5.02 & & & & \\
\hline PGSP0143 & Feb/21/1993 & $12: 53$ & 4.93 & & & & \\
\hline PGSP0144 & $\mathrm{Feb} / 21 / 1993$ & $13: 13$ & 4.88 & & & & \\
\hline PGSP0145 & Feb/21/1993 & $14: 13$ & 4.93 & & & & \\
\hline PGSP0146 & Feb/21/1993 & $15: 13$ & 5.02 & & & & \\
\hline PGSP0147 & \begin{tabular}{|l|l|} 
Feb/21/1993 \\
\end{tabular} & $16: 13$ & 5.18 & & & & \\
\hline PGSP0148 & Feb/21/1993 & $17: 13$ & 5.11 & & & & \\
\hline PGSP0149 & Feb/21/1993 & $18: 13$ & 5.11 & & & & \\
\hline PGSP0150 & Feb/21/1993 & 19:13 & 5.20 & & & & \\
\hline PGSP0151 & Feb/21/1993 & $20: 13$ & 5.24 & & & & \\
\hline PGSP0152 & \begin{tabular}{|l|l|} 
Feb/21/1993 \\
\end{tabular} & $21: 13$ & 5.24 & & & & \\
\hline PGSP0153 & Feb/21/1993 & $22: 13$ & 5.00 & & & & \\
\hline PGSP0154 & Feb/21/1993 & $23: 13$ & 5.20 & & & & \\
\hline PGSP0155 & Feb/22/1993 & $3: 13$ & 5.20 & & & & \\
\hline PGSP0156 & Feb/22/1993 & $7: 13$ & 5.20 & & & & \\
\hline PGSP0157 & \begin{tabular}{|l|l|} 
Feb/22/1993 \\
\end{tabular} & $11: 13$ & 5.13 & & & & \\
\hline PGSP0158 & \begin{tabular}{|l} 
Feb/22/1993 \\
\end{tabular} & $15: 13$ & 5.29 & & & & \\
\hline PGSP0159 & Mar/03/1993 & $9: 00$ & 4.66 & & & & 0.078 \\
\hline PGSP0160 & Mar/18/1993 & $10: 20$ & 5.45 & & & & \\
\hline PGSP0161 & Mar/22/1993 & $20: 15$ & 5.22 & & & & \\
\hline PGSP0172 & \begin{tabular}{|l} 
Mar/23/1993 \\
\end{tabular} & $1: 15$ & 5.15 & & & & \\
\hline PGSP0176 & Mar/23/1993 & $5: 15$ & 5.09 & & & & \\
\hline PGSP0180 & Mar/23/1993 & $9: 15$ & 5.00 & & & & \\
\hline PGSP0181 & Mar/23/1993 & $13: 15$ & 4.45 & & & & \\
\hline PGSP0182 & Mar/23/1993 & $17: 15$ & 4.48 & & & & \\
\hline PGSP0183 & Mar/23/1993 & $21: 15$ & 4.86 & & & & \\
\hline PGSP0184 & Mar/24/1993 & $1: 15$ & 4.90 & & & & \\
\hline PGSP0185 & Mar/25/1993 & 11:00 & 5.33 & & & & \\
\hline PGSP0186 & Mar/26/1993 & $2: 28$ & 5.20 & & & & \\
\hline PGSP0187 & Mar/26/1993 & $2: 48$ & 5.09 & & & & \\
\hline PGSP0188 & Mar/26/1993 & $3: 08$ & 5.02 & & & & \\
\hline PGSP0189 & Mar/26/1993 & $3: 28$ & 5.13 & & & & \\
\hline PGSP0190 & Mar/26/1993 & $3: 48$ & 5.13 & & & & \\
\hline PGSP0191 & Mar/26/1993 & $4: 08$ & 5.13 & & & & \\
\hline PGSP0192 & \begin{tabular}{|l} 
Mar/26/1993 \\
\end{tabular} & $4: 28$ & 4.75 & & & & \\
\hline PGSP0193 & Mar/26/1993 & $4: 48$ & 5.06 & & & & \\
\hline PGSP0194 & Mar/26/1993 & $5: 08$ & 5.04 & & & & \\
\hline PGSP0195 & Mar/26/1993 & $5: 28$ & 5.04 & & & & \\
\hline PGSP0196 & Mar/26/1993 & $6: 28$ & 5.06 & & & & \\
\hline PGSP0197 & \begin{tabular}{|l} 
Mar/26/1993 \\
\end{tabular} & $7: 28$ & 5.24 & & & & \\
\hline PGSP0198 & Mar/26/1993 & $8: 28$ & 5.18 & & & & \\
\hline PGSP0199 & Mar/26/1993 & $9: 28$ & 5.24 & & & & \\
\hline PGSP0200 & Mar/26/1993 & $10: 28$ & 5.18 & & & & \\
\hline PGSP0201 & Mar/26/1993 & $11: 28$ & 4.77 & & & & \\
\hline PGSP0202 & Mar/26/1993 & $12: 28$ & 4.48 & & & & \\
\hline PGSP0203 & Mar/26/1993 & $13: 28$ & 4.38 & & & & \\
\hline PGSP0204 & Mar/26/1993 & $14: 28$ & 4.43 & & & & \\
\hline PGSP0205 & Mar/26/1993 & $15: 28$ & 4.50 & & & & \\
\hline PGSP0206 & Mar/26/1993 & 19:28 & 4.52 & & & & \\
\hline PGSP0207 & Mar/26/1993 & $23: 28$ & 4.84 & & & & \\
\hline PGSP0208 & Mar/27/1993 & $3: 28$ & 5.09 & & & & \\
\hline PGSP0209 & Mar/27/1993 & $7: 28$ & 5.09 & & & & \\
\hline
\end{tabular}

*These statistics are presented as a descriptive summary of the table. The effects of aliasing and variable sampling intervals may significantly affect the validity of averages presented as representative of ground-water quality in the basin. No data means an analysis was not performed. 
Pleasant Grove Spring, October 1992-September 1993

\begin{tabular}{|c|c|c|c|c|c|c|c|}
\hline $\begin{array}{l}\text { Sample } \\
\text { Number }\end{array}$ & Date & Time (CST) & $\begin{array}{l}\text { Total Nitrate- } \\
\text { Nitrogen } \\
\text { (mg/L as N) }\end{array}$ & $\begin{array}{c}\text { Total Nitrite } \\
\left(\mathrm{mg} / \mathrm{L} \text { as } \mathrm{NO}_{2}^{-}\right)\end{array}$ & $\begin{array}{c}\text { Ammonia } \\
\left(\mathrm{mg} / \mathrm{L} \text { as } \mathrm{NH}_{3}\right)\end{array}$ & $\begin{array}{c}\text { Total Kjeldahl } \\
\text { Nitrogen } \\
\text { (mg/L as N) }\end{array}$ & $\begin{array}{l}\text { Orthophosphate } \\
\left(\mathrm{mg} / \mathrm{L} \text { as } \mathrm{PO}_{4}^{-3}\right)\end{array}$ \\
\hline PGSP0210 & 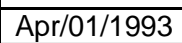 & $16: 54$ & 5.15 & & & & \\
\hline PGSP0211 & 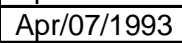 & $8: 22$ & 5.09 & & & & 0.033 \\
\hline PGSP0212 & \begin{tabular}{|c|c|} 
Apr/21/1993 \\
\end{tabular} & $15: 10$ & 5.04 & & & & \\
\hline PGSP0213 & May/03/1993 & $17: 39$ & 4.70 & & & & \\
\hline PGSP0214 & May/03/1993 & $18: 39$ & 4.81 & & & & \\
\hline PGSP0215 & \begin{tabular}{|l|l} 
May/04/1993 \\
\end{tabular} & $13: 55$ & 4.25 & & & & 0.310 \\
\hline PGSP0216 & May/04/1993 & $14: 50$ & 4.84 & & & & \\
\hline PGSP0217 & May/04/1993 & $15: 50$ & 5.06 & & & & \\
\hline PGSP0218 & May/04/1993 & $16: 50$ & 5.06 & & & & \\
\hline PGSP0219 & May/04/1993 & $17: 50$ & 5.20 & & & & \\
\hline PGSP0220 & May/04/1993 & $18: 50$ & 5.29 & & & & \\
\hline PGSP0221 & \begin{tabular}{|l|l} 
May/04/1993 \\
\end{tabular} & 19:50 & 5.27 & & & & \\
\hline PGSP0222 & May/04/1993 & $20: 50$ & 5.31 & & & & \\
\hline PGSP0223 & May/04/1993 & $21: 50$ & 5.38 & & & & \\
\hline PGSP0224 & May/04/1993 & $22: 50$ & 5.38 & & & & \\
\hline PGSP0225 & $\mid$ May/05/1993 & $1: 50$ & 5.56 & & & & \\
\hline PGSP0226 & May/05/1993 & $4: 50$ & 5.79 & & & & \\
\hline PGSP0227 & May/05/1993 & $7: 50$ & 5.97 & & & & \\
\hline PGSP0228 & May/05/1993 & $10: 50$ & 6.08 & & & & \\
\hline \begin{tabular}{|l|} 
PGSP0229 \\
\end{tabular} & \begin{tabular}{|l|l} 
May/05/1993 \\
\end{tabular} & $13: 50$ & 5.81 & & & & \\
\hline PGSP0230 & May/05/1993 & $16: 50$ & 5.94 & & & & \\
\hline PGSP0231 & May/05/1993 & 19:50 & 5.74 & & & & \\
\hline PGSP0232 & May/05/1993 & $22: 50$ & 5.74 & & & & \\
\hline PGSP0233 & May/06/1993 & $1: 50$ & 5.94 & & & & \\
\hline PGSP0234 & May/06/1993 & $9: 15$ & 5.62 & & & & \\
\hline PGSP0235 & May/18/1993 & $3: 22$ & 4.88 & & & & \\
\hline PGSP0241 & May/18/1993 & $9: 22$ & 4.95 & & & & \\
\hline PGSP0251 & May/19/1993 & $9: 22$ & 5.06 & & & & \\
\hline PGSP0255 & May/20/1993 & $9: 42$ & 4.90 & & & & \\
\hline PGSP0256 & \begin{tabular}{|l|l|} 
May/21/1993 \\
\end{tabular} & $2: 15$ & 5.11 & & & & \\
\hline PGSP0257 & May/22/1993 & $2: 15$ & 4.97 & & & & \\
\hline PGSP0258 & May/23/1993 & $2: 15$ & 4.84 & & & & \\
\hline PGSP0259 & \begin{tabular}{|l|l|} 
May/24/1993 \\
\end{tabular} & $2: 15$ & 4.84 & & & & \\
\hline PGSP0260 & May/26/1993 & $12: 42$ & 5.00 & & & & \\
\hline PGSP0261 & May/29/1993 & $18: 50$ & 4.56 & & & & \\
\hline PGSP0262 & 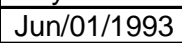 & $16: 29$ & 5.20 & & & & \\
\hline PGSP0263 & Jun/02/1993 & $4: 29$ & 5.44 & & & & \\
\hline PGSP0264 & \begin{tabular}{|l|l|} 
Jun/02/1993 \\
\end{tabular} & $14: 30$ & & & & & 0.040 \\
\hline PGSP0265 & Jun/08/1993 & $17: 14$ & 4.83 & & & & \\
\hline PGSP0266 & \begin{tabular}{|l|l|} 
Jun/16/1993 \\
\end{tabular} & $6: 05$ & 4.88 & & & & \\
\hline PGSP0267 & \begin{tabular}{|l} 
Jun/24/1993 \\
\end{tabular} & $9: 23$ & 4.83 & & & & \\
\hline PGSP0268 & Jun/24/1993 & 19:52 & 4.47 & & & & \\
\hline PGSP0269 & 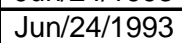 & $20: 52$ & 4.56 & & & & \\
\hline PGSP0270 & Jun/24/1993 & $21: 52$ & 4.41 & & & & \\
\hline PGSP0271 & 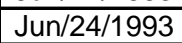 & $22: 52$ & 4.55 & & & & \\
\hline PGSP0272 & \begin{tabular}{|l|l|l|} 
Jun/24/1993 \\
\end{tabular} & $23: 52$ & 4.60 & & & & \\
\hline PGSP0273 & Jun/25/1993 & $0: 52$ & 4.57 & & & & \\
\hline PGSP0274 & \begin{tabular}{|l|l} 
Jun/25/1993 \\
\end{tabular} & $1: 52$ & 4.56 & & & & \\
\hline PGSP0275 & \begin{tabular}{|l|l|l} 
Jun/25/1993 \\
\end{tabular} & $2: 52$ & 4.56 & & & & \\
\hline PGSP0276 & \begin{tabular}{|l|} 
Jun/25/1993 \\
\end{tabular} & $3: 52$ & 4.53 & & & & \\
\hline PGSP0277 & \begin{tabular}{|l|l|l} 
Jun/25/1993 \\
\end{tabular} & $4: 52$ & 4.54 & & & & \\
\hline PGSP0278 & \begin{tabular}{|l|l|l|} 
Jun/25/1993 \\
\end{tabular} & $7: 52$ & 4.65 & & & & \\
\hline PGSP0279 & \begin{tabular}{|l} 
Jun/25/1993 \\
\end{tabular} & $10: 52$ & 4.64 & & & & \\
\hline PGSP0280 & \begin{tabular}{|l|l|l} 
Jun/25/1993 \\
\end{tabular} & $13: 52$ & 4.55 & & & & \\
\hline PGSP0281 & |Jun/25/1993 & $16: 52$ & 4.59 & & & & \\
\hline
\end{tabular}

*These statistics are presented as a descriptive summary of the table. The effects of aliasing and variable sampling intervals may significantly affect the validity of averages presented as representative of ground-water quality in the basin. No data means an analysis was not performed. 
Pleasant Grove Spring, October 1992-September 1993

\begin{tabular}{|c|c|c|c|c|c|c|c|}
\hline $\begin{array}{l}\text { Sample } \\
\text { Number }\end{array}$ & Date & Time (CST) & $\begin{array}{c}\text { Total Nitrate- } \\
\text { Nitrogen } \\
\text { (mg/L as } N)\end{array}$ & 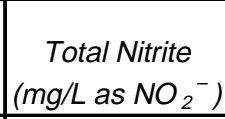 & $\begin{array}{c}\text { Ammonia } \\
\left(\mathrm{mg} / \mathrm{L} \text { as } \mathrm{NH}_{3}\right)\end{array}$ & $\begin{array}{c}\text { Total Kjeldahl } \\
\text { Nitrogen } \\
\text { (mg/L as } N) \\
\end{array}$ & $\begin{array}{l}\text { Orthophosphate } \\
\left(\mathrm{mg} / \mathrm{L}_{\text {as }} \mathrm{PO}_{4}{ }^{-3}\right)\end{array}$ \\
\hline PGSP0282 & Jun/25/1993 & $19: 52$ & 4.69 & & & & \\
\hline PGSP0283 & Jun/25/1993 & $22: 52$ & 4.80 & & & & \\
\hline PGSP0284 & Jun/26/1993 & $1: 52$ & 4.49 & & & & \\
\hline PGSP0285 & Jun/26/1993 & $4: 52$ & 4.05 & & & & \\
\hline PGSP0286 & Jun/26/1993 & $7: 52$ & 3.61 & & & & \\
\hline PGSP0287 & Jun/26/1993 & $10: 52$ & 3.51 & & & & \\
\hline PGSP0288 & Jun/26/1993 & $22: 52$ & 3.83 & & & & \\
\hline PGSP0289 & \begin{tabular}{|l|} 
Jun/27/1993 \\
\end{tabular} & $10: 52$ & 4.22 & & & & \\
\hline PGSP0290 & Jun/27/1993 & $22: 52$ & 4.42 & & & & \\
\hline PGSP0291 & Jun/28/1993 & $10: 52$ & 4.47 & & & & \\
\hline PGSP0292 & Jun/29/1993 & 11:00 & 4.43 & & & & 0.152 \\
\hline PGSP0293 & Jul/02/1993 & $16: 04$ & 3.54 & & & & \\
\hline PGSP0294 & \begin{tabular}{|l|} 
Jul/03/1993 \\
\end{tabular} & 13:04 & 4.14 & & & & \\
\hline PGSP0295 & Jul/15/1993 & $12: 08$ & 4.44 & & & & \\
\hline PGSP0296 & Jul/16/1993 & $11: 30$ & & & & & \\
\hline PGSP0297 & Jul/22/1993 & $11: 20$ & & & & & \\
\hline PGSP0298 & Jul/29/1993 & 9:46 & 5.42 & & & & \\
\hline PGSP0299 & Aug/04/1993 & 9:00 & 6.33 & & & & 0.041 \\
\hline PGSP0300 & Aug/14/1993 & $15: 53$ & 5.49 & & & & \\
\hline PGSP0301 & Aug/24/1993 & $12: 18$ & 5.13 & & & & \\
\hline PGSP0302 & Sep/09/1993 & $7: 30$ & 5.65 & & & & 0.030 \\
\hline & & Average* $^{\star}$ & 4.98 & & & & 0.078 \\
\hline & & Maximum & 6.33 & & & & 0.310 \\
\hline & & Minimum & 3.51 & & & & 0.300 \\
\hline & & Stand. Dev. & 0.46 & & & & 0.081 \\
\hline & & Coef. Var. & 0.09 & & & & 1.038 \\
\hline
\end{tabular}

Spring Valley karst window, October 1992-September 1993

\begin{tabular}{|c|c|c|c|c|c|c|c|}
\hline $\begin{array}{l}\text { Sample } \\
\text { Number }\end{array}$ & Date & Time (CST) & $\begin{array}{c}\text { Total Nitrate- } \\
\text { Nitrogen } \\
\text { (mg/L as N) }\end{array}$ & 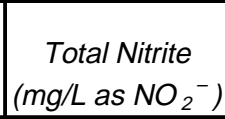 & $\begin{array}{c}\text { Ammonia } \\
\left(\mathrm{mg} / \mathrm{L} \text { as } \mathrm{NH}_{3}\right)\end{array}$ & $\begin{array}{c}\text { Total Kjeldahl } \\
\text { Nitrogen } \\
\text { (mg/L as } N)\end{array}$ & $\begin{array}{l}\text { Orthophosphate } \\
\left(\mathrm{mg} / \mathrm{L}_{\text {as }} \mathrm{PO}_{4}{ }^{-3}\right)\end{array}$ \\
\hline SVKW0015 & May/20/1993 & $9: 20$ & 5.01 & & & & \\
\hline SVKW0016 & May/26/1993 & $12: 10$ & 5.11 & & & & \\
\hline & & Average $^{\star}$ & 5.06 & & & & \\
\hline
\end{tabular}

*These statistics are presented as a descriptive summary of the table. The effects of aliasing and variable sampling intervals may significantly affect the validity of averages presented as representative of ground-water quality in the basin. No data means an analysis was not performed. 
George Delaney swallow hole, October 1992-September 1993

\begin{tabular}{|c|c|c|c|c|c|c|c|}
\hline $\begin{array}{l}\text { Sample } \\
\text { Number }\end{array}$ & Date & Time (CST) & $\begin{array}{l}\text { Total Nitrate- } \\
\text { Nitrogen } \\
\text { (mg/L as N) }\end{array}$ & $\begin{array}{c}\text { Total Nitrite } \\
\left(\mathrm{mg} / \mathrm{L} \text { as } \mathrm{NO}_{2}^{-}\right)\end{array}$ & $\begin{array}{c}\text { Ammonia } \\
\left(\mathrm{mg} / \mathrm{L} \text { as } \mathrm{NH}_{3}\right)\end{array}$ & $\begin{array}{c}\text { Total Kjeldahl } \\
\text { Nitrogen } \\
\text { (mg/L as } N \text { ) } \\
\end{array}$ & $\begin{array}{l}\text { Orthophosphate } \\
\left(\mathrm{mg} / \mathrm{L} \text { as } \mathrm{PO}_{4}^{-3}\right)\end{array}$ \\
\hline GDSW0009 & May/20/1993 & $8: 14$ & 6.98 & & & & \\
\hline GDSW0010 & May/26/1993 & $11: 50$ & 6.66 & & & & \\
\hline GDSW0011 & Jun/17/1993 & $8: 20$ & 5.56 & & & & \\
\hline & & Average* & 6.40 & & & & \\
\hline & & Maximum & 6.98 & & & & \\
\hline & & Minimum & 5.56 & & & & \\
\hline
\end{tabular}

Leslie Page karst window, October 1992-September 1993

\begin{tabular}{|c|c|c|c|c|c|c|c|}
\hline $\begin{array}{l}\text { Sample } \\
\text { Number }\end{array}$ & Date & Time (CST) & $\begin{array}{l}\text { Total Nitrate- } \\
\text { Nitrogen } \\
\text { (mg/L as N) }\end{array}$ & $\begin{array}{c}\text { Total Nitrite } \\
\left(\mathrm{mg} / \mathrm{L} \text { as } \mathrm{NO}_{2}^{-}\right)\end{array}$ & $\begin{array}{c}\text { Ammonia } \\
\left(\mathrm{mg} / \mathrm{L} \text { as } \mathrm{NH}_{3}\right)\end{array}$ & $\begin{array}{c}\text { Total Kjeldahl } \\
\text { Nitrogen } \\
\text { (mg/L as N) }\end{array}$ & $\begin{array}{l}\text { Orthophosphate } \\
\left(\mathrm{mg} / \mathrm{L}_{\text {as }} \mathrm{PO}_{4}{ }^{-3}\right)\end{array}$ \\
\hline LPKW0001 & Apr/10/1993 & $18: 00$ & 5.15 & & & & \\
\hline \begin{tabular}{|l} 
LPKW0002 \\
\end{tabular} & Apr/11/1993 & $6: 00$ & 5.31 & & & & \\
\hline LPKW0003 & Apr/11/1993 & $18: 00$ & 4.88 & & & & \\
\hline \begin{tabular}{|l} 
LPKW0004 \\
\end{tabular} & Apr/12/1993 & $6: 00$ & 5.08 & & & & \\
\hline \begin{tabular}{|l} 
LPKW0005 \\
\end{tabular} & Apr/12/1993 & $18: 00$ & 4.97 & & & & \\
\hline LPKW0006 & Apr/13/1993 & $6: 00$ & 5.11 & & & & \\
\hline \begin{tabular}{|l} 
LPKW0007 \\
\end{tabular} & May/05/1993 & $8: 17$ & 4.38 & & & & \\
\hline \begin{tabular}{|l|l|} 
LPKW0099 \\
\end{tabular} & May/20/1993 & $11: 10$ & 4.86 & & & & \\
\hline \begin{tabular}{|l|l} 
LPKW0010 \\
\end{tabular} & May/26/1993 & $11: 30$ & 4.88 & & & & \\
\hline LPKW010A & Jun/02/1993 & $16: 50$ & & & & & \\
\hline \begin{tabular}{|l|} 
LPKW0011 \\
\end{tabular} & Jun/08/1993 & $8: 34$ & 4.90 & & & & \\
\hline \begin{tabular}{|l|l|} 
LPKW0012 \\
\end{tabular} & Jun/17/1993 & 9:50 & 4.72 & & & & \\
\hline \begin{tabular}{|l|l|l} 
LPKW013 \\
\end{tabular} & Jun/24/1993 & $10: 00$ & 4.72 & & & & \\
\hline LPKW0014 & Jun/30/1993 & $9: 45$ & 4.49 & & & & \\
\hline \begin{tabular}{|l|l|l} 
LPKW015 \\
\end{tabular} & Jul/15/1993 & $11: 22$ & 4.22 & & & & \\
\hline \multirow[t]{6}{*}{ LPKW0017 } & Jul/29/1993 & $10: 32$ & 5.24 & & & & \\
\hline & & Average ${ }^{*}$ & 4.86 & & & & \\
\hline & & Maximum & 5.31 & & & & \\
\hline & & \begin{tabular}{|l|} 
Minimum \\
\end{tabular} & 4.22 & & & & \\
\hline & & Stand. Dev. & 0.31 & & & & \\
\hline & & Coef. Var. & 0.06 & & & & \\
\hline
\end{tabular}

Upper Pleasant Grove Creek, October 1992-September 1993

\begin{tabular}{|c|c|c|c|c|c|c|c|}
\hline $\begin{array}{l}\text { Sample } \\
\text { Number }\end{array}$ & Date & Time (CST) & $\begin{array}{l}\text { Total Nitrate- } \\
\text { Nitrogen } \\
\text { (mg/L as N) }\end{array}$ & $\begin{array}{c}\text { Total Nitrite } \\
\left(\mathrm{mg} / \mathrm{L} \text { as } \mathrm{NO}_{2}^{-}\right)\end{array}$ & $\begin{array}{c}\text { Ammonia } \\
\left(\mathrm{mg} / \mathrm{L} \text { as } \mathrm{NH}_{3}\right)\end{array}$ & $\begin{array}{l}\text { Total Kjeldahl } \\
\text { Nitrogen } \\
\text { (mg/L as N) }\end{array}$ & $\begin{array}{l}\text { Orthophosphate } \\
\left(\mathrm{mg} / \mathrm{L} \text { as } \mathrm{PO}_{4}{ }^{-3}\right)\end{array}$ \\
\hline UPGC0001 & Jun/17/1993 & $7: 25$ & 8.00 & & & & \\
\hline UPGC0002 & Jun/30/1993 & $9: 10$ & 6.33 & & & & \\
\hline UPGC0003 & Aug/03/1993 & $15: 33$ & 8.00 & & & & \\
\hline & & Average ${ }^{*}$ & $\overline{77.44}$ & & & & \\
\hline & & Maximum & 8.00 & & & & \\
\hline & & Minimum & 6.33 & & & & \\
\hline
\end{tabular}

*These statistics are presented as a descriptive summary of the table. The effects of aliasing and variable sampling intervals may significantly affect the validity of averages presented as representative of ground-water quality in the basin. No data means an analysis was not performed. 
Pleasant Grove Spring, October 1992-September 1993

\begin{tabular}{|c|c|c|c|c|c|c|}
\hline $\begin{array}{l}\text { Sample } \\
\text { Number }\end{array}$ & $\begin{array}{c}\text { Laboratory } \\
\mathrm{pH}\end{array}$ & $\begin{array}{c}\text { Laboratory } \\
\text { Specific } \\
\text { Conductance } \\
\left(\text { at } 25^{\circ} \mathrm{C}\right)(\mu S)\end{array}$ & $\begin{array}{c}\text { Total Alkalinity } \\
\text { (mg/L as CaCO3) }\end{array}$ & $\begin{array}{c}\text { Dissolved } \\
\text { Solids Residue } \\
\text { on Evaporation } \\
\left.\text { ( } \mathrm{mg} / \mathrm{L} 180^{\circ} \mathrm{C}\right)\end{array}$ & $\begin{array}{l}\text { Suspended } \\
\quad \text { Solids } \\
\text { Residue on } \\
\text { Evaporation } \\
(\mathrm{mg} / \mathrm{L} \\
\left.180^{\circ} \mathrm{C}\right)\end{array}$ & $\begin{array}{c}\text { Total Iron } \\
(m g / L \text { as } F e)\end{array}$ \\
\hline PGSP0065 & 7.26 & 478 & 235 & 248 & 3 & 0.111 \\
\hline PGSP0067 & 7.64 & 547 & 241 & 258 & 3 & 0.007 \\
\hline PGSP0070 & 7.25 & 488 & 241 & 300 & 3 & 0.006 \\
\hline PGSP0071 & 7.16 & 432 & 198 & 212 & 8 & 0.279 \\
\hline PGSP0084 & & & & 258 & 8 & \\
\hline PGSP0089 & & & & 224 & 7 & \\
\hline PGSP0095 & & & & 248 & 6 & \\
\hline PGSP0101 & & & & 260 & 5 & \\
\hline PGSP0107 & & & & 254 & 7 & \\
\hline PGSP0108 & 7.07 & 464 & 198 & 254 & 4 & 0.122 \\
\hline PGSP0109 & & & & 256 & 4 & \\
\hline PGSP0110 & & & & 264 & 6 & \\
\hline PGSP0111 & & & & 260 & 7 & \\
\hline PGSP0112 & & & & 286 & 8 & \\
\hline PGSP0113 & & & & 266 & 7 & \\
\hline PGSP0114 & & & & 262 & 9 & \\
\hline PGSP0115 & & & & 260 & 10 & \\
\hline PGSP0116 & & & & 258 & 12 & \\
\hline PGSP0117 & & & & 242 & 12 & \\
\hline PGSP0118 & & & & 244 & 16 & \\
\hline PGSP0119 & & & & 248 & 18 & \\
\hline PGSP0120 & & & & 256 & 22 & \\
\hline PGSP0121 & & & & 256 & 22 & \\
\hline PGSP0122 & & & & 252 & 22 & \\
\hline PGSP0123 & & & & 274 & 18 & \\
\hline PGSP0124 & & & & 266 & 11 & \\
\hline PGSP0125 & & & & 288 & 22 & \\
\hline PGSP0126 & & & & 266 & 21 & \\
\hline PGSP0127 & & & & 268 & 22 & \\
\hline PGSP0128 & & & & 274 & 18 & \\
\hline PGSP0129 & & & & 232 & 25 & \\
\hline PGSP0130 & & & & 238 & 21 & \\
\hline PGSP0131 & & & & 214 & 18 & \\
\hline PGSP0132 & & & & 230 & 14 & \\
\hline PGSP0133 & & & & 238 & 11 & \\
\hline PGSP0134 & & & & 246 & 8 & \\
\hline PGSP0135 & & & & 248 & 46 & \\
\hline PGSP0136 & & & & 270 & 42 & \\
\hline PGSP0137 & & & & 250 & 55 & \\
\hline PGSP0138 & & & & 260 & 64 & \\
\hline PGSP0139 & & & & 258 & 82 & \\
\hline PGSP0140 & & & & 262 & 76 & \\
\hline PGSP0141 & & & & 226 & 67 & \\
\hline PGSP0142 & & & & 228 & 72 & \\
\hline PGSP0143 & & & & 234 & 87 & \\
\hline
\end{tabular}


Pleasant Grove Spring, October 1992-September 1993

\begin{tabular}{|c|c|c|c|c|c|c|}
\hline $\begin{array}{l}\text { Sample } \\
\text { Number }\end{array}$ & $\begin{array}{l}\text { Laboratory } \\
\mathrm{pH}\end{array}$ & $\begin{array}{c}\text { Laboratory } \\
\text { Specific } \\
\text { Conductance } \\
\left(\text { at } 25^{\circ} \mathrm{C}\right)(\mu S)\end{array}$ & $\begin{array}{c}\text { Total Alkalinity } \\
\text { (mg/L as CaCO3) }\end{array}$ & $\begin{array}{c}\text { Dissolved } \\
\text { Solids Residue } \\
\text { on Evaporation } \\
\left(\mathrm{mg} / \mathrm{L} 180^{\circ} \mathrm{C}\right)\end{array}$ & $\begin{array}{c}\text { Suspended } \\
\text { Solids } \\
\text { Residue on } \\
\text { Evaporation } \\
(\mathrm{mg} / \mathrm{L} \\
\left.180^{\circ} \mathrm{C}\right)\end{array}$ & $\begin{array}{c}\text { Total Iron } \\
(m g / L \text { as } F e)\end{array}$ \\
\hline PGSP0144 & & & & 216 & 82 & \\
\hline PGSP0145 & & & & 236 & 53 & \\
\hline PGSP0146 & & & & 242 & 68 & \\
\hline PGSP0147 & & & & 262 & 87 & \\
\hline PGSP0148 & & & & 258 & 96 & \\
\hline PGSP0149 & & & & 236 & 132 & \\
\hline PGSP0150 & & & & 246 & 176 & \\
\hline PGSP0151 & & & & 252 & 232 & \\
\hline PGSP0152 & & & & 230 & 240 & \\
\hline PGSP0153 & & & & 546 & 239 & \\
\hline PGSP0154 & & & & 548 & 226 & \\
\hline PGSP0155 & & & & 542 & 162 & \\
\hline PGSP0156 & & & & 548 & 116 & \\
\hline PGSP0157 & & & & 564 & 83 & \\
\hline PGSP0158 & & & & 554 & 66 & \\
\hline PGSP0159 & 7.38 & 406 & 141 & 222 & 63 & 2.930 \\
\hline PGSP0161 & & & & 250 & 5 & \\
\hline PGSP0172 & & & & 268 & 48 & \\
\hline PGSP0176 & & & & 242 & 36 & \\
\hline PGSP0180 & & & & 240 & 53 & \\
\hline PGSP0181 & & & & 236 & 64 & \\
\hline PGSP0182 & & & & 228 & 42 & \\
\hline PGSP0183 & & & & 230 & 29 & \\
\hline PGSP0184 & & & & 226 & 29 & \\
\hline PGSP0185 & & & & 244 & 10 & \\
\hline PGSP0186 & & & & 242 & 38 & \\
\hline PGSP0187 & & & & 258 & 41 & \\
\hline PGSP0188 & & & & 248 & 40 & \\
\hline PGSP0189 & & & & 238 & 40 & \\
\hline PGSP0190 & & & & 242 & 45 & \\
\hline PGSP0191 & & & & 246 & 47 & \\
\hline PGSP0192 & & & & 238 & 48 & \\
\hline PGSP0193 & & & & 250 & 51 & \\
\hline PGSP0194 & & & & 268 & 53 & \\
\hline PGSP0195 & & & & 258 & 62 & \\
\hline PGSP0196 & & & & 272 & 89 & \\
\hline PGSP0197 & & & & 270 & 104 & \\
\hline PGSP0198 & & & & 278 & 135 & \\
\hline PGSP0199 & & & & 208 & 167 & \\
\hline PGSP0200 & & & & 212 & 212 & \\
\hline PGSP0201 & & & & 212 & 211 & \\
\hline PGSP0202 & & & & 210 & 191 & \\
\hline PGSP0203 & & & & 220 & 174 & \\
\hline PGSP0204 & & & & 210 & 150 & \\
\hline PGSP0205 & & & & 154 & 130 & \\
\hline
\end{tabular}


Pleasant Grove Spring, October 1992-September 1993

\begin{tabular}{|c|c|c|c|c|c|c|}
\hline $\begin{array}{l}\text { Sample } \\
\text { Number }\end{array}$ & $\begin{array}{l}\text { Laboratory } \\
\mathrm{pH}\end{array}$ & $\begin{array}{c}\text { Laboratory } \\
\text { Specific } \\
\text { Conductance } \\
\left(\text { at } 25^{\circ} \mathrm{C}\right)(\mu S)\end{array}$ & $\begin{array}{c}\text { Total Alkalinity } \\
\text { (mg/L as CaCO3) }\end{array}$ & $\begin{array}{c}\text { Dissolved } \\
\text { Solids Residue } \\
\text { on Evaporation } \\
\text { ( } \mathrm{mg} / \mathrm{L} 180^{\circ} \mathrm{C} \text { ) }\end{array}$ & \begin{tabular}{|c|} 
Suspended \\
Solids \\
Residue on \\
Evaporation \\
$(\mathrm{mg} / \mathrm{L}$ \\
$\left.180^{\circ} \mathrm{C}\right)$ \\
\end{tabular} & $\begin{array}{c}\text { Total Iron } \\
(\mathrm{mg} / \mathrm{L} \text { as Fe })\end{array}$ \\
\hline PGSP0206 & & & & 162 & 90 & \\
\hline PGSP0207 & & & & 178 & 72 & \\
\hline PGSP0208 & & & & 176 & 63 & \\
\hline PGSP0209 & & & & 180 & 56 & \\
\hline PGSP0210 & & & & 180 & 34 & \\
\hline PGSP0211 & 7.63 & 395 & 149 & 248 & 6 & 0.123 \\
\hline PGSP0213 & & & & 272 & 14 & \\
\hline PGSP0214 & & & & 214 & 98 & \\
\hline PGSP0215 & 7.23 & 241 & 98 & 176 & 201 & 7.170 \\
\hline PGSP0216 & & & & 200 & 202 & \\
\hline PGSP0217 & & & & 206 & 162 & \\
\hline PGSP0218 & & & & 528 & 184 & \\
\hline PGSP0219 & & & & 400 & 164 & \\
\hline PGSP0220 & & & & 498 & 170 & \\
\hline PGSP0221 & & & & 466 & 156 & \\
\hline PGSP0222 & & & & 468 & 164 & \\
\hline PGSP0223 & & & & 274 & 146 & \\
\hline PGSP0224 & & & & 194 & 160 & \\
\hline PGSP0225 & & & & 192 & 134 & \\
\hline PGSP0226 & & & & 214 & 120 & \\
\hline PGSP0227 & & & & 218 & 108 & \\
\hline PGSP0228 & & & & 232 & 100 & \\
\hline PGSP0229 & & & & 216 & 160 & \\
\hline PGSP0230 & & & & 298 & 94 & \\
\hline PGSP0231 & & & & 302 & 86 & \\
\hline PGSP0232 & & & & 292 & 86 & \\
\hline PGSP0233 & & & & 310 & 70 & \\
\hline PGSP0234 & & & & 304 & 76 & \\
\hline PGSP0264 & 7.25 & 424 & 195 & 270 & 11 & 0.117 \\
\hline PGSP0268 & & & & 238 & 14 & \\
\hline PGSP0269 & & & & 240 & 12 & \\
\hline PGSP0270 & & & & 228 & 21 & \\
\hline PGSP0271 & & & & 262 & 10 & \\
\hline PGSP0272 & & & & 262 & 8 & \\
\hline PGSP0273 & & & & 242 & 10 & \\
\hline PGSP0274 & & & & 246 & 12 & \\
\hline PGSP0275 & & & & 236 & 15 & \\
\hline PGSP0276 & & & & 214 & 16 & \\
\hline PGSP0277 & & & & 220 & 22 & \\
\hline PGSP0278 & & & & 224 & 17 & \\
\hline PGSP0279 & & & & 244 & 27 & \\
\hline PGSP0280 & & & & 226 & 13 & \\
\hline PGSP0281 & & & & 286 & 16 & \\
\hline PGSP0282 & & & & 204 & 56 & \\
\hline PGSP0283 & & & & 272 & 28 & \\
\hline
\end{tabular}


Pleasant Grove Spring, October 1992-September 1993

\begin{tabular}{|c|c|c|c|c|c|c|}
\hline $\begin{array}{l}\text { Sample } \\
\text { Number }\end{array}$ & $\begin{array}{l}\text { Laboratory } \\
\mathrm{pH}\end{array}$ & $\begin{array}{c}\text { Laboratory } \\
\text { Specific } \\
\text { Conductance } \\
\left(\text { at } 25^{\circ} \mathrm{C}\right)(\mu S)\end{array}$ & $\begin{array}{c}\text { Total Alkalinity } \\
\text { (mg/L as CaCO3) }\end{array}$ & $\begin{array}{c}\text { Dissolved } \\
\text { Solids Residue } \\
\text { on Evaporation } \\
\text { ( } \mathrm{mg} / \mathrm{L} 180^{\circ} \mathrm{C} \text { ) }\end{array}$ & $\begin{array}{c}\text { Suspended } \\
\text { Solids } \\
\text { Residue on } \\
\text { Evaporation } \\
(\mathrm{mg} / \mathrm{L} \\
\left.180^{\circ} \mathrm{C}\right)\end{array}$ & $\begin{array}{c}\text { Total Iron } \\
(\mathrm{mg} / \mathrm{L} \text { as } \mathrm{Fe})\end{array}$ \\
\hline PGSP0284 & & & & 370 & 61 & \\
\hline PGSP0285 & & & & 348 & 69 & \\
\hline PGSP0286 & & & & 266 & 80 & \\
\hline PGSP0287 & & & & 258 & 74 & \\
\hline PGSP0288 & & & & 294 & 27 & \\
\hline PGSP0289 & & & & 298 & 8 & \\
\hline PGSP0290 & & & & 316 & 14 & \\
\hline PGSP0291 & & & & 336 & 8 & \\
\hline PGSP0292 & 7.00 & 438 & 214 & 258 & 10 & 0.166 \\
\hline PGSP0299 & 7.15 & 405 & 232 & 276 & 3 & \\
\hline Average* & $\overline{7.27}$ & 429 & 194.73 & 267 & $\bar{~} 64.36$ & $\bar{~} 1.103$ \\
\hline Maximum & 7.64 & 547 & 241 & 564 & 240 & 7.170 \\
\hline Minimum & 7.00 & 241 & 98 & 154 & 3 & 0.006 \\
\hline Stand. Dev. & 0.21 & 76.6 & 46.93 & 79.5 & 62.77 & 2.309 \\
\hline Coef. Var. & 0.03 & 0.2 & 0.24 & 0.3 & 0.98 & 2.093 \\
\hline
\end{tabular}

Pleasant Grove Spring, October 1992-September 1993

\begin{tabular}{|c|c|c|c|c|c|c|c|}
\hline $\begin{array}{l}\text { Sample } \\
\text { Number }\end{array}$ & $\begin{array}{c}\text { Total } \\
\text { Calcium } \\
\text { (mg/L as Ca })\end{array}$ & $\begin{array}{c}\text { Total } \\
\text { Magnesium } \\
\text { (mg/L as Mg) }\end{array}$ & $\begin{array}{l}\text { Total Sodium } \\
\text { ( } \mathrm{mg} / \mathrm{L} \text { as } \mathrm{Na})\end{array}$ & $\begin{array}{c}\text { Total } \\
\text { Potassium } \\
\text { (mg/L as K) }\end{array}$ & $\begin{array}{c}\text { Bicarbonate } \\
(\mathrm{mg} / \mathrm{L} \text { as } \\
\left.\mathrm{HCO}_{3}{ }^{-}\right)\end{array}$ & $\begin{array}{c}\text { Total Sulfate } \\
\left(\mathrm{mg}_{\mathrm{L}} \mathrm{L} \text { as }\right. \\
\left.\mathrm{SO}_{4}^{-2}\right)\end{array}$ & $\begin{array}{l}\text { Dissolved } \\
\text { Chloride } \\
\text { (mg/L as Cl) }\end{array}$ \\
\hline PGSP0065 & 85.00 & 8.48 & 2.39 & 1.28 & 286 & 5.85 & 6.15 \\
\hline PGSP0067 & 85.20 & 8.49 & 2.38 & 1.28 & 294 & 5.89 & 5.46 \\
\hline PGSP0070 & 87.40 & 8.80 & 2.46 & 1.28 & 294 & 5.65 & 5.67 \\
\hline PGSP0071 & 76.20 & 6.82 & 2.79 & 2.06 & 241 & 5.78 & 6.50 \\
\hline$\overline{P G S P 0108}$ & 79.40 & 7.24 & 2.67 & 1.28 & 241 & 5.26 & 6.19 \\
\hline PGSP0159 & 55.30 & 5.02 & 0.21 & 2.59 & 172 & 6.61 & 6.23 \\
\hline PGSP0211 & 68.50 & 6.04 & 2.50 & 1.28 & 182 & 5.36 & 6.86 \\
\hline PGSP0215 & 41.20 & 4.38 & 1.42 & 5.08 & 119 & 6.34 & 5.33 \\
\hline PGSP0299 & & & & & 283 & 5.37 & 6.09 \\
\hline PGSP0302 & 89.40 & 9.09 & 2.42 & 1.21 & 294 & 5.43 & 5.76 \\
\hline Average $^{\star}$ & 744.18 & $\overline{77.15}$ & 2.14 & 1.93 & $\overline{235.56}$ & "5.75 & "6.02 \\
\hline Maximum & 89.40 & 9.09 & 2.79 & 5.08 & 294 & 6.61 & 6.86 \\
\hline \begin{tabular}{|l|} 
Minimum \\
\end{tabular} & 41.20 & 4.38 & 0.21 & 1.21 & 119 & 5.26 & 5.33 \\
\hline Stand. Dev & 16.40 & 1.72 & 0.82 & 1.28 & 64.28 & 0.44 & 0.47 \\
\hline Coef. Var. & 0.22 & 0.24 & 0.38 & 0.66 & 0.27 & 0.08 & 0.08 \\
\hline
\end{tabular}

*These statistics are presented as a descriptive summary of the table. The effects of aliasing and variable sampling intervals may significantly affect the validity of averages presented as representative of ground-water quality in the basin. No data means an analysis was not performed. 
Pleasant Grove Spring, October 1993-September 1994

\begin{tabular}{|c|c|c|c|c|c|c|c|}
\hline $\begin{array}{l}\text { Sample } \\
\text { Number }\end{array}$ & Date & Time (CST) & $\begin{array}{l}\text { Total Nitrate- } \\
\text { Nitrogen } \\
\text { (mg/L as N) }\end{array}$ & $\begin{array}{c}\text { Total Nitrite } \\
\left(\mathrm{mg} / \mathrm{L} \text { as } \mathrm{NO}_{2}{ }^{-}\right)\end{array}$ & $\begin{array}{c}\text { Ammonia } \\
\left(m g / L \text { as } \mathrm{NH}_{3}\right) \\
\end{array}$ & $\begin{array}{l}\text { Total Kjeldahl } \\
\text { Nitrogen } \\
\text { (mg/L as } N) \\
\end{array}$ & $\begin{array}{c}\text { Orthophosphate } \\
\text { (mg/L as } \\
\mathrm{PO}_{4}^{-3} \text { ) }\end{array}$ \\
\hline PGSP0303 & Oct/06/1993 & $7: 30$ & 5.40 & & & & 0.032 \\
\hline PGSP0304 & Nov/09/1993 & $10: 45$ & 5.01 & & & & 0.035 \\
\hline PGSP0305 & Nov/18/1993 & $12: 37$ & 5.33 & & & & \\
\hline PGSP0306 & $\mathrm{Dec} / 08 / 1993$ & $9: 30$ & 7.66 & & & & \\
\hline PGSP0307 & Dec/09/1993 & $21: 04$ & 7.55 & & & & \\
\hline PGSP0308 & $\mathrm{Dec} / 09 / 1993$ & $22: 04$ & 7.50 & & & & \\
\hline PGSP0309 & $\mathrm{Dec} / 09 / 1993$ & $23: 04$ & 7.36 & & & & \\
\hline PGSP0310 & $\mathrm{Dec} / 10 / 1993$ & $0: 04$ & 7.30 & & & & \\
\hline PGSP0311 & $\mathrm{Dec} / 10 / 1993$ & $1: 04$ & 7.36 & & & & \\
\hline PGSP0312 & $\mathrm{Dec} / 10 / 1993$ & $2: 04$ & 7.27 & & & & \\
\hline PGSP0313 & $\mathrm{Dec} / 10 / 1993$ & $3: 04$ & 7.16 & & & & \\
\hline PGSP0314 & $\mathrm{Dec} / 10 / 1993$ & $4: 04$ & 7.34 & & & & \\
\hline PGSP0315 & $\mathrm{Dec} / 10 / 1993$ & 5:04 & 6.98 & & & & \\
\hline PGSP0316 & $\mathrm{Dec} / 10 / 1993$ & $6: 04$ & 6.82 & & & & \\
\hline PGSP0317 & $\mathrm{Dec} / 10 / 1993$ & $9: 04$ & 6.37 & & & & \\
\hline PGSP0318 & Dec/10/1993 & $12: 04$ & 5.11 & & & & \\
\hline PGSP0319 & $\mathrm{Dec} / 10 / 1993$ & $15: 04$ & 5.15 & & & & \\
\hline PGSP0320 & $\mathrm{Dec} / 10 / 1993$ & 18:04 & 5.60 & & & & \\
\hline PGSP0321 & $\mathrm{Dec} / 10 / 1993$ & $21: 04$ & 6.14 & & & & \\
\hline PGSP0322 & $\mathrm{Dec} / 11 / 1993$ & $0: 04$ & 6.51 & & & & \\
\hline PGSP0323 & Dec/11/1993 & $3: 04$ & 6.87 & & & & \\
\hline PGSP0324 & $\mathrm{Dec} / 11 / 1993$ & $6: 04$ & 7.16 & & & & \\
\hline PGSP0325 & $\mathrm{Dec} / 11 / 1993$ & 9:04 & 7.07 & & & & \\
\hline PGSP0326 & $\mathrm{Dec} / 11 / 1993$ & $12: 04$ & 7.18 & & & & \\
\hline PGSP0327 & $\mathrm{Dec} / 12 / 1993$ & $0: 04$ & 7.50 & & & & \\
\hline PGSP0328 & Dec/12/1993 & $12: 04$ & 7.77 & & & & \\
\hline PGSP0329 & $\mathrm{Dec} / 13 / 1993$ & $0: 04$ & 7.55 & & & & \\
\hline PGSP0330 & Dec/13/1993 & $12: 04$ & 7.82 & & & & \\
\hline PGSP0332 & $\mathrm{Dec} / 29 / 1993$ & $12: 55$ & 7.07 & & & & \\
\hline PGSP0333 & Jan/02/1994 & $3: 55$ & 6.84 & & & & \\
\hline PGSP0334 & Jan/12/1994 & $11: 40$ & 7.16 & & & & \\
\hline PGSP0335 & Jan/24/1994 & $17: 24$ & 4.90 & & & & \\
\hline PGSP0336 & Jan/24/1994 & $20: 24$ & 4.65 & & & & \\
\hline PGSP0337 & Jan/25/1994 & $8: 24$ & 4.88 & & & & \\
\hline PGSP0338 & Jan/25/1994 & $20: 24$ & 3.75 & & & & \\
\hline PGSP0339 & Jan/26/1994 & $8: 24$ & 5.04 & & & & \\
\hline PGSP0340 & Jan/26/1994 & $20: 24$ & 6.42 & & & & \\
\hline PGSP0341 & Jan/27/1994 & $8: 50$ & 6.66 & & & & \\
\hline PGSP0342 & Feb/02/1994 & $12: 10$ & 7.34 & & & & \\
\hline PGSP0343 & Feb/22/1994 & $11: 20$ & 7.05 & & & & 0.053 \\
\hline PGSP0344 & Mar/01/1994 & $11: 00$ & 7.05 & & & & \\
\hline PGSP0345 & Mar/09/1994 & $9: 00$ & 3.82 & & & & \\
\hline PGSP0346 & Mar/15/1994 & $15: 57$ & 6.82 & & & & \\
\hline PGSP0347 & Mar/27/1994 & $5: 30$ & 5.47 & & & & \\
\hline PGSP0348 & Mar/27/1994 & $6: 10$ & 5.81 & & & & \\
\hline PGSP0349 & Mar/27/1994 & $6: 50$ & 3.75 & & & & \\
\hline PGSP0350 & Mar/27/1994 & $7: 30$ & 3.14 & & & & \\
\hline PGSP0351 & Mar/27/1994 & $8: 10$ & 2.96 & & & & \\
\hline PGSP0352 & Mar/27/1994 & $9: 30$ & 2.76 & & & & \\
\hline PGSP0353 & Mar/27/1994 & $11: 30$ & 3.12 & & & & \\
\hline PGSP0354 & Mar/27/1994 & $13: 30$ & 3.43 & & & & \\
\hline PGSP0355 & Mar/27/1994 & $14: 30$ & 3.46 & & & & \\
\hline PGSP0356 & Mar/27/1994 & $15: 30$ & 3.66 & & & & \\
\hline PGSP0357 & Mar/27/1994 & $16: 30$ & 3.84 & & & & \\
\hline
\end{tabular}

*These statistics are presented as a descriptive summary of the table. The effects of aliasing and variable sampling intervals may significantly affect the validity of averages presented as representative of ground-water quality in the basin. No data means an analysis was not performed. 
Pleasant Grove Spring, October 1993-September 1994

\begin{tabular}{|c|c|c|c|c|c|c|c|}
\hline $\begin{array}{l}\text { Sample } \\
\text { Number }\end{array}$ & Date & Time (CST) & $\begin{array}{l}\text { Total Nitrate- } \\
\text { Nitrogen } \\
\text { (mg/L as N) }\end{array}$ & $\begin{array}{c}\text { Total Nitrite } \\
\left(\mathrm{mg} / \mathrm{L} \text { as } \mathrm{NO}_{2}^{-}\right)\end{array}$ & $\begin{array}{c}\text { Ammonia } \\
\left(\mathrm{mg} / \mathrm{L} \text { as } \mathrm{NH}_{3}\right)\end{array}$ & $\begin{array}{c}\text { Total Kjeldahl } \\
\text { Nitrogen } \\
\text { (mg/L as } N)\end{array}$ & $\begin{array}{c}\text { Orthophosphate } \\
\text { (mg/L as } \\
\left.\mathrm{PO}_{4}{ }^{-3}\right)\end{array}$ \\
\hline PGSP0358 & \begin{tabular}{|l|l|}
$\operatorname{Mar} / 27 / 1994$ \\
\end{tabular} & $17: 30$ & 3.98 & & & & \\
\hline PGSP0359 & Mar/27/1994 & $18: 30$ & 4.04 & & & & \\
\hline PGSP0360 & \begin{tabular}{|l|}
$\operatorname{Mar} / 27 / 1994$ \\
\end{tabular} & $22: 30$ & 4.38 & & & & \\
\hline PGSP0361 & Mar/28/1994 & $2: 30$ & 3.91 & & & & \\
\hline PGSP0362 & \begin{tabular}{|l|}
$\operatorname{Mar} / 28 / 1994$ \\
\end{tabular} & $6: 30$ & 4.16 & & & & \\
\hline PGSP0363 & \begin{tabular}{|l|}
$\operatorname{Mar} / 28 / 1994$ \\
\end{tabular} & $10: 30$ & 4.65 & & & & \\
\hline PGSP0364 & Mar/28/1994 & $13: 00$ & 4.95 & & & & 0.138 \\
\hline PGSP0365 & \begin{tabular}{|l|l|}
$\operatorname{Mar} / 28 / 1994$ \\
\end{tabular} & $18: 00$ & 5.35 & & & & \\
\hline PGSP0366 & Mar/29/1994 & $6: 00$ & 5.47 & & & & \\
\hline PGSP0367 & \begin{tabular}{|l|}
$\operatorname{Mar} / 29 / 1994$ \\
\end{tabular} & $18: 00$ & 5.74 & & & & \\
\hline PGSP0368 & Mar/30/1994 & $6: 00$ & 5.90 & & & & \\
\hline PGSP0369 & Mar/30/1994 & 18:00 & 6.23 & & & & \\
\hline PGSP0370 & \begin{tabular}{|l|}
$\operatorname{Mar} / 31 / 1994$ \\
\end{tabular} & $6: 00$ & 6.23 & & & & \\
\hline PGSP0371 & \begin{tabular}{|l|} 
Mar/31/1994 \\
\end{tabular} & $18: 00$ & 5.81 & & & & \\
\hline PGSP0372 & \begin{tabular}{|l|l|} 
Apr/01/1994 \\
\end{tabular} & $6: 00$ & 6.30 & & & & \\
\hline PGSP0373 & Apr/01/1994 & $18: 00$ & 5.58 & & & & \\
\hline PGSP0374 & \begin{tabular}{|l|l|} 
Apr/02/1994 \\
\end{tabular} & $6: 00$ & 6.12 & & & & \\
\hline PGSP0375 & \begin{tabular}{|c|} 
Apr/02/1994 \\
\end{tabular} & $18: 00$ & 6.28 & & & & \\
\hline PGSP0376 & \begin{tabular}{|c|} 
Apr/03/1994 \\
\end{tabular} & $6: 00$ & 6.23 & & & & \\
\hline PGSP0377 & \begin{tabular}{|l|l|} 
Apr/03/1994 \\
\end{tabular} & $18: 00$ & 6.30 & & & & \\
\hline PGSP0378 & Apr/04/1994 & $6: 00$ & 5.99 & & & & \\
\hline PGSP0379 & \begin{tabular}{|l|} 
Apr/04/1994 \\
\end{tabular} & $18: 00$ & 6.35 & & & & \\
\hline PGSP0380 & \begin{tabular}{|l|l|} 
Apr/05/1994 \\
\end{tabular} & $6: 00$ & 6.23 & & & & \\
\hline PGSP0381 & \begin{tabular}{|l|l|} 
Apr/05/1994 \\
\end{tabular} & $18: 00$ & 6.28 & & & & \\
\hline PGSP0382 & \begin{tabular}{|l|l} 
Apr/06/1994 \\
\end{tabular} & $6: 00$ & 5.58 & & & & \\
\hline PGSP0383 & Apr/06/1994 & $18: 00$ & 5.87 & & & & \\
\hline PGSP0384 & \begin{tabular}{|l|} 
Apr/07/1994 \\
\end{tabular} & $6: 00$ & 6.12 & & & & \\
\hline PGSP0385 & Apr/07/1994 & $14: 00$ & 6.14 & & & & \\
\hline PGSP0387 & \begin{tabular}{|l|l|} 
Apr/11/1994 \\
\end{tabular} & $14: 13$ & 2.37 & & & & \\
\hline PGSP0388 & \begin{tabular}{|c|} 
Apr/11/1994 \\
\end{tabular} & $17: 57$ & 3.14 & & & & \\
\hline PGSP0389 & Apr/12/1994 & $7: 30$ & 5.38 & & & & \\
\hline PGSP0391 & \begin{tabular}{|l|l} 
Apr/12/1994 \\
\end{tabular} & $15: 30$ & 5.67 & & & & \\
\hline PGSP0392 & \begin{tabular}{|c|} 
Apr/13/1994 \\
\end{tabular} & $6: 15$ & 5.65 & & & & \\
\hline PGSP0393 & \begin{tabular}{|l|l} 
Apr/13/1994 \\
\end{tabular} & $18: 00$ & 6.10 & & & & \\
\hline PGSP0394 & \begin{tabular}{|l|l} 
Apr/14/1994 \\
\end{tabular} & $6: 00$ & 6.17 & & & & \\
\hline PGSP0395 & \begin{tabular}{|c|} 
Apr/14/1994 \\
\end{tabular} & $18: 00$ & 6.28 & & & & \\
\hline PGSP0396 & \begin{tabular}{|l|l} 
Apr/15/1994 \\
\end{tabular} & $6: 00$ & 6.23 & & & & \\
\hline PGSP0397 & Apr/15/1994 & $18: 00$ & 4.99 & & & & \\
\hline PGSP0398 & \begin{tabular}{|l|l} 
Apr/16/1994 \\
\end{tabular} & $6: 00$ & 5.08 & & & & \\
\hline PGSP0399 & Apr/16/1994 & $18: 00$ & 5.78 & & & & \\
\hline PGSP0400 & \begin{tabular}{|l|l|} 
Apr/17/1994 \\
\end{tabular} & $6: 00$ & 6.05 & & & & \\
\hline PGSP0401 & \begin{tabular}{|l|l} 
Apr/17/1994 \\
\end{tabular} & $18: 00$ & 6.26 & & & & \\
\hline PGSP0402 & \begin{tabular}{|c|} 
Apr/18/1994 \\
\end{tabular} & $6: 00$ & 6.12 & & & & \\
\hline PGSP0403 & \begin{tabular}{|l|l} 
Apr/18/1994 \\
\end{tabular} & $18: 00$ & 6.10 & & & & \\
\hline PGSP0404 & Apr/19/1994 & $6: 00$ & 6.08 & & & & \\
\hline PGSP404A & \begin{tabular}{|l|l|} 
Apr/20/1994 \\
\end{tabular} & $6: 00$ & 4.27 & & & & \\
\hline PGSP0405 & \begin{tabular}{|c|} 
Apr/21/1994 \\
\end{tabular} & $6: 00$ & 4.77 & & & & \\
\hline PGSP0406 & \begin{tabular}{|l|l|} 
Apr/22/1994 \\
\end{tabular} & $6: 00$ & 4.43 & & & & \\
\hline PGSP0407 & \begin{tabular}{|l|} 
Apr/23/1994 \\
\end{tabular} & $6: 00$ & 4.34 & & & & \\
\hline PGSP0408 & \begin{tabular}{|l|l|} 
Apr/24/1994 \\
\end{tabular} & $6: 00$ & 4.04 & & & & \\
\hline PGSP0409 & \begin{tabular}{|l|l|} 
Apr/25/1994 \\
\end{tabular} & $6: 00$ & 4.25 & & & & \\
\hline PGSP0410 & Apr/26/1994 & $6: 00$ & 4.02 & & & & \\
\hline PGSP0411 & \begin{tabular}{|c|} 
Apr/27/1994 \\
\end{tabular} & $6: 00$ & 4.09 & & & & \\
\hline PGSP0412 & \begin{tabular}{|l|l|} 
Apr/27/1994 \\
\end{tabular} & $10: 00$ & 4.11 & & & & 0.509 \\
\hline
\end{tabular}

*These statistics are presented as a descriptive summary of the table. The effects of aliasing and variable sampling intervals may significantly affect the validity of averages presented as representative of ground-water quality in the basin. No data means an analysis was not performed. 
Pleasant Grove Spring, October 1993-September 1994

\begin{tabular}{|c|c|c|c|c|c|c|c|}
\hline $\begin{array}{l}\text { Sample } \\
\text { Number }\end{array}$ & Date & Time (CST) & $\begin{array}{c}\text { Total Nitrate- } \\
\text { Nitrogen } \\
\text { (mg/L as } N)\end{array}$ & $\begin{array}{c}\text { Total Nitrite } \\
\left(\mathrm{mg} / \mathrm{L} \text { as } \mathrm{NO}_{2}{ }^{-}\right)\end{array}$ & $\begin{array}{c}\text { Ammonia } \\
\left(m g / L \text { as } \mathrm{NH}_{3}\right) \\
\end{array}$ & $\begin{array}{l}\text { Total Kjeldahl } \\
\text { Nitrogen } \\
\text { (mg/L as } N) \\
\end{array}$ & $\begin{array}{c}\text { Orthophosphate } \\
\text { (mg/L as } \\
\mathrm{PO}_{4}^{-3} \text { ) }\end{array}$ \\
\hline PGSP0413 & Apr/28/1994 & $6: 00$ & 3.91 & & & & \\
\hline PGSP0414 & Apr/29/1994 & $6: 00$ & 3.98 & & & & \\
\hline PGSP0415 & Apr/29/1994 & $18: 00$ & 4.00 & & & & \\
\hline PGSP0416 & Apr/29/1994 & $18: 45$ & 4.77 & & & & \\
\hline PGSP0417 & Apr/29/1994 & 19:05 & 4.36 & & & & \\
\hline PGSP0418 & Apr/29/1994 & $19: 09$ & 4.61 & & & & \\
\hline PGSP0419 & Apr/29/1994 & $19: 25$ & 4.52 & & & & \\
\hline PGSP0420 & Apr/29/1994 & $19: 45$ & 4.54 & & & & \\
\hline PGSP0421 & Apr/29/1994 & $19: 51$ & 4.61 & & & & \\
\hline PGSP0422 & Apr/29/1994 & $20: 05$ & 4.70 & & & & \\
\hline PGSP0423 & Apr/29/1994 & $20: 25$ & 4.59 & & & & \\
\hline PGSP0424 & Apr/29/1994 & $20: 45$ & 4.38 & & & & \\
\hline PGSP0425 & Apr/29/1994 & $21: 05$ & 4.47 & & & & \\
\hline PGSP0426 & Apr/29/1994 & $21: 25$ & 4.07 & & & & \\
\hline PGSP0427 & Apr/29/1994 & $21: 45$ & 3.89 & & & & \\
\hline PGSP0428 & Apr/29/1994 & $22: 45$ & 4.20 & & & & \\
\hline PGSP0429 & Apr/29/1994 & $23: 45$ & 3.70 & & & & \\
\hline PGSP0430 & Apr/30/1994 & $0: 45$ & 3.52 & & & & \\
\hline PGSP0431 & Apr/30/1994 & $1: 45$ & 3.32 & & & & \\
\hline PGSP0432 & Apr/30/1994 & $2: 45$ & 3.09 & & & & \\
\hline PGSP0433 & Apr/30/1994 & $3: 45$ & 3.05 & & & & \\
\hline PGSP0434 & Apr/30/1994 & $4: 45$ & 3.19 & & & & \\
\hline PGSP0435 & Apr/30/1994 & $5: 45$ & 3.16 & & & & \\
\hline PGSP0436 & Apr/30/1994 & $6: 45$ & 3.32 & & & & \\
\hline PGSP0437 & Apr/30/1994 & $7: 45$ & 3.39 & & & & \\
\hline PGSP0438 & Apr/30/1994 & $11: 45$ & 3.68 & & & & \\
\hline PGSP0439 & Apr/30/1994 & $15: 45$ & 4.07 & & & & \\
\hline PGSP0440 & May/01/1994 & $6: 00$ & 4.27 & & & & \\
\hline PGSP0441 & May/02/1994 & $6: 00$ & 4.61 & & & & \\
\hline PGSP0442 & May/03/1994 & $6: 00$ & 4.09 & & & & \\
\hline PGSP0443 & May/04/1994 & $6: 00$ & 4.38 & & & & \\
\hline PGSP0444 & May/04/1994 & $18: 00$ & 4.34 & & & & \\
\hline PGSP0445 & \begin{tabular}{|l|} 
May/05/1994 \\
\end{tabular} & $6: 00$ & 4.34 & & & & \\
\hline PGSP0446 & May/07/1994 & $6: 00$ & 4.22 & & & & \\
\hline PGSP0447 & May/09/1994 & $6: 00$ & 4.47 & & & & \\
\hline PGSP0448 & May/11/1994 & $6: 00$ & 4.36 & & & & \\
\hline PGSP0449 & May/12/1994 & 9:00 & 4.36 & & & & \\
\hline PGSP0450 & May/13/1994 & $6: 00$ & 4.20 & & & & \\
\hline PGSP0451 & May/14/1994 & $6: 00$ & 4.22 & & & & \\
\hline PGSP0452 & May/15/1994 & $6: 00$ & 3.98 & & & & \\
\hline PGSP0453 & May/15/1994 & $18: 00$ & 4.29 & & & & \\
\hline PGSP0454 & May/16/1994 & $6: 00$ & 4.04 & & & & \\
\hline PGSP0455 & May/17/1994 & $6: 00$ & 4.22 & & & & \\
\hline PGSP0456 & May/18/1994 & $6: 00$ & 4.41 & & & & \\
\hline PGSP0457 & May/20/1994 & $6: 00$ & 4.45 & & & & \\
\hline PGSP0458 & May/22/1994 & $6: 00$ & 4.34 & & & & \\
\hline PGSP0459 & May/24/1994 & $6: 00$ & 4.29 & & & & \\
\hline PGSP0460 & May/26/1994 & $6: 00$ & 4.29 & & & & \\
\hline PGSP0461 & May/28/1994 & $6: 00$ & 3.95 & & & & \\
\hline PGSP0462 & May/30/1994 & $6: 00$ & 4.25 & & & & \\
\hline PGSP0463 & Jun/01/1994 & $12: 00$ & 4.20 & & & & \\
\hline PGSP0464 & Jun/03/1994 & $6: 00$ & 4.22 & & & & \\
\hline PGSP0465 & Jun/05/1994 & $6: 00$ & 3.84 & & & & \\
\hline PGSP0466 & Jun/07/1994 & $6: 00$ & 4.22 & & & & \\
\hline
\end{tabular}

*These statistics are presented as a descriptive summary of the table. The effects of aliasing and variable sampling intervals may significantly affect the validity of averages presented as representative of ground-water quality in the basin. No data means an analysis was not performed. 
Pleasant Grove Spring, October 1993-September 1994

\begin{tabular}{|c|c|c|c|c|c|c|c|}
\hline $\begin{array}{l}\text { Sample } \\
\text { Number }\end{array}$ & Date & Time (CST) & $\begin{array}{l}\text { Total Nitrate- } \\
\text { Nitrogen } \\
\text { (mg/L as N) }\end{array}$ & $\begin{array}{c}\text { Total Nitrite } \\
\left(\mathrm{mg} / \mathrm{L} \text { as } \mathrm{NO}_{2}^{-}\right)\end{array}$ & $\begin{array}{c}\text { Ammonia } \\
\left(m g / L \text { as } \mathrm{NH}_{3}\right)\end{array}$ & $\begin{array}{c}\text { Total Kjeldahl } \\
\text { Nitrogen } \\
\text { (mg/L as } N)\end{array}$ & $\begin{array}{c}\text { Orthophosphate } \\
\text { (mg/L as } \\
\left.\mathrm{PO}_{4}{ }^{-3}\right)\end{array}$ \\
\hline PGSP0467 & 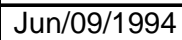 & $6: 00$ & 4.43 & & & & \\
\hline PGSP0468 & \begin{tabular}{|l|l|} 
Jun/10/1994 \\
\end{tabular} & $6: 00$ & 4.59 & & & & \\
\hline PGSP0469 & \begin{tabular}{|l|l|} 
Jun/10/1994 \\
\end{tabular} & 11:01 & 4.74 & & & & \\
\hline PGSP0470 & \begin{tabular}{|l|l|} 
Jun/10/1994 \\
\end{tabular} & $11: 21$ & 4.70 & & & & \\
\hline PGSP0471 & \begin{tabular}{|l|l|l|} 
Jun/10/1994 \\
\end{tabular} & $11: 41$ & 4.72 & & & & \\
\hline PGSP0472 & \begin{tabular}{|l|l|l|} 
Jun/1099 \\
\end{tabular} & 12:01 & 4.65 & & & & \\
\hline PGSP0473 & \begin{tabular}{|l|l}
$J u n / 10 / 1994$ \\
\end{tabular} & $12: 21$ & 4.65 & & & & \\
\hline PGSP0474 & \begin{tabular}{|l|l|} 
Jun/10/1994 \\
\end{tabular} & $12: 41$ & 4.72 & & & & \\
\hline PGSP0475 & Jun/10/1994 & 13:01 & 4.65 & & & & \\
\hline PGSP0476 & \begin{tabular}{|l|l|} 
Jun/10/1994 \\
\end{tabular} & $13: 21$ & 4.74 & & & & \\
\hline PGSP0477 & \begin{tabular}{|l|l|}
$J u n / 10 / 1994$ \\
\end{tabular} & $13: 41$ & 4.63 & & & & \\
\hline PGSP0478 & \begin{tabular}{|l|l|l|} 
Jun/10/1994 \\
\end{tabular} & 14:01 & 4.70 & & & & \\
\hline PGSP0479 & \begin{tabular}{|l|l|} 
Jun/10/1994 \\
\end{tabular} & 15:01 & 4.36 & & & & \\
\hline PGSP0480 & \begin{tabular}{|l|l|} 
Jun/10/1994 \\
\end{tabular} & 16:01 & 4.74 & & & & \\
\hline PGSP0481 & \begin{tabular}{|l|l|} 
Jun/10/1994 \\
\end{tabular} & $17: 01$ & 4.65 & & & & \\
\hline PGSP0482 & \begin{tabular}{|l|l|} 
Jun/10/1994 \\
\end{tabular} & 18:01 & 4.70 & & & & \\
\hline PGSP0483 & \begin{tabular}{|l|l|l|} 
Jun/10/1994 \\
\end{tabular} & 19:01 & 4.61 & & & & \\
\hline PGSP0484 & \begin{tabular}{|l|l|} 
Jun/10/1994 \\
\end{tabular} & $20: 01$ & 4.63 & & & & \\
\hline PGSP0485 & Jun/10/1994 & $21: 01$ & 4.68 & & & & \\
\hline PGSP0486 & \begin{tabular}{|l|l|} 
Jun/10/1994 \\
\end{tabular} & $22: 01$ & 4.65 & & & & \\
\hline PGSP0487 & Jun/10/1994 & $23: 01$ & 4.61 & & & & \\
\hline PGSP0488 & \begin{tabular}{|l|l|} 
Jun/11/1994 \\
\end{tabular} & $0: 01$ & 4.61 & & & & \\
\hline PGSP0489 & 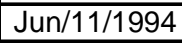 & 4:01 & 4.61 & & & & \\
\hline PGSP0490 & \begin{tabular}{|l|l|l|} 
Jun/11/1994 \\
\end{tabular} & $6: 00$ & 4.13 & & & & \\
\hline PGSP0491 & \begin{tabular}{|l|l|} 
Jun/11/1994 \\
\end{tabular} & $8: 01$ & 4.56 & & & & \\
\hline PGSP0492 & \begin{tabular}{|l|l|l|} 
Jun/11/1994 \\
\end{tabular} & 12:01 & 4.50 & & & & \\
\hline PGSP0493 & \begin{tabular}{|l|l|} 
Jun/11/1994 \\
\end{tabular} & 16:01 & 4.52 & & & & \\
\hline PGSP0494 & \begin{tabular}{|l|l|} 
Jun/14/1994 \\
\end{tabular} & $6: 00$ & 4.52 & & & & \\
\hline PGSP0495 & \begin{tabular}{|l|l|} 
Jun/16/1994 \\
\end{tabular} & $6: 00$ & 4.11 & & & & \\
\hline PGSP0496 & \begin{tabular}{|l|l|} 
Jun/17/1994 \\
\end{tabular} & $6: 00$ & 4.18 & & & & \\
\hline PGSP0497 & Jun/17/1994 & $21: 13$ & 4.59 & & & & \\
\hline PGSP0498 & Jun/17/1994 & $21: 33$ & 4.63 & & & & \\
\hline PGSP0499 & Jun/17/1994 & $21: 53$ & 4.65 & & & & \\
\hline PGSP0500 & \begin{tabular}{|l|l|} 
Jun/17/1994 \\
\end{tabular} & $22: 13$ & 4.63 & & & & \\
\hline PGSP0501 & \begin{tabular}{|l|l|} 
Jun/17/1994 \\
\end{tabular} & $22: 33$ & 4.59 & & & & \\
\hline PGSP0502 & \begin{tabular}{|l|l|l|} 
Jun/17/1994 \\
\end{tabular} & $22: 53$ & 4.65 & & & & \\
\hline PGSP0503 & \begin{tabular}{|l|l|} 
Jun/17/1994 \\
\end{tabular} & $23: 13$ & & & & & \\
\hline PGSP0504 & \begin{tabular}{|l|l|l|} 
Jun/17/1994 \\
\end{tabular} & $23: 33$ & 4.72 & & & & \\
\hline PGSP0505 & \begin{tabular}{|l|l|} 
Jun/17/1994 \\
\end{tabular} & $23: 53$ & 4.81 & & & & \\
\hline PGSP0506 & \begin{tabular}{|l|l|} 
Jun/18/1994 \\
\end{tabular} & $0: 13$ & 4.70 & & & & \\
\hline PGSP0507 & \begin{tabular}{|l|l|} 
Jun/18/1994 \\
\end{tabular} & $1: 13$ & 4.79 & & & & \\
\hline PGSP0508 & \begin{tabular}{|l|l|} 
Jun/18/1994 \\
\end{tabular} & $2: 13$ & 4.25 & & & & \\
\hline PGSP0509 & \begin{tabular}{|l|l|}
$J u n / 18 / 1994$ \\
\end{tabular} & $3: 13$ & 3.23 & & & & \\
\hline PGSP0510 & \begin{tabular}{|l|l|} 
Jun/18/1994 \\
\end{tabular} & $4: 13$ & 3.23 & & & & \\
\hline PGSP0511 & \begin{tabular}{|l|l}
$J u n / 18 / 1994$ \\
\end{tabular} & $5: 13$ & 3.37 & & & & \\
\hline PGSP0512 & \begin{tabular}{|l} 
Jun/18/1994 \\
\end{tabular} & $6: 13$ & 3.39 & & & & \\
\hline PGSP0513 & \begin{tabular}{|l|l|} 
Jun/18/1994 \\
\end{tabular} & $7: 13$ & 3.50 & & & & \\
\hline PGSP0514 & \begin{tabular}{|l|l|} 
Jun/18/1994 \\
\end{tabular} & $8: 13$ & 3.57 & & & & \\
\hline PGSP0515 & \begin{tabular}{|l|l|} 
Jun/18/1994 \\
\end{tabular} & 9:13 & 3.52 & & & & \\
\hline PGSP0516 & \begin{tabular}{|l|l|} 
Jun/18/1994 \\
\end{tabular} & $10: 13$ & 3.59 & & & & \\
\hline PGSP0517 & \begin{tabular}{|l|l|} 
Jun/18/1994 \\
\end{tabular} & $14: 13$ & 3.50 & & & & \\
\hline PGSP0518 & \begin{tabular}{|l|l|} 
Jun/18/1994 \\
\end{tabular} & $18: 13$ & 3.48 & & & & \\
\hline PGSP0519 & \begin{tabular}{|l|} 
Jun/18/1994 \\
\end{tabular} & $22: 13$ & 3.66 & & & & \\
\hline PGSP0520 & \begin{tabular}{|l|l|} 
Jun/19/1994 \\
\end{tabular} & $2: 13$ & 3.75 & & & & \\
\hline
\end{tabular}

*These statistics are presented as a descriptive summary of the table. The effects of aliasing and variable sampling intervals may significantly affect the validity of averages presented as representative of ground-water quality in the basin. No data means an analysis was not performed. 
Pleasant Grove Spring, October 1993-September 1994

\begin{tabular}{|c|c|c|c|c|c|c|c|}
\hline $\begin{array}{l}\text { Sample } \\
\text { Number }\end{array}$ & Date & Time (CST) & $\begin{array}{l}\text { Total Nitrate- } \\
\text { Nitrogen } \\
\text { (mg/L as } N)\end{array}$ & $\begin{array}{c}\text { Total Nitrite } \\
\left(\mathrm{mg} / \mathrm{L}_{\text {as }} \mathrm{NO}_{2}{ }^{-}\right)\end{array}$ & $\begin{array}{c}\text { Ammonia } \\
\left(\mathrm{mg} / \mathrm{L} \text { as } \mathrm{NH}_{3}\right)\end{array}$ & $\begin{array}{c}\text { Total Kjeldahl } \\
\text { Nitrogen } \\
\text { (mg/L as } N)\end{array}$ & $\begin{array}{c}\text { Orthophosphate } \\
\text { (mg/L as } \\
\left.\mathrm{PO}_{4}{ }^{-3}\right)\end{array}$ \\
\hline PGSP0521 & \begin{tabular}{|l|l|} 
Jun/20/1994 \\
\end{tabular} & $6: 00$ & 4.22 & & & & \\
\hline PGSP0522 & Jun/22/1994 & $6: 00$ & 4.07 & & & & \\
\hline PGSP0523 & Jun/24/1994 & $6: 00$ & 4.09 & & & & \\
\hline PGSP0524 & \begin{tabular}{|l|l|} 
Jun/26/1994 \\
\end{tabular} & $6: 00$ & 4.16 & & & & \\
\hline PGSP0525 & Jun/29/1994 & $6: 00$ & 4.16 & & & & \\
\hline PGSP0526 & Jul/01/1994 & $6: 00$ & 4.27 & & & & \\
\hline PGSP0527 & Jul/03/1994 & $6: 00$ & 4.22 & & & & \\
\hline PGSP0528 & Jul/05/1994 & $6: 00$ & 4.22 & & & & \\
\hline PGSP0529 & Jul/06/1994 & $10: 30$ & 4.41 & & & & \\
\hline PGSP0530 & Jul/07/1994 & $6: 00$ & 4.16 & & & & \\
\hline PGSP0531 & Jul/07/1994 & $6: 30$ & 3.95 & & & & \\
\hline PGSP0532 & Jul/07/1994 & $7: 10$ & 3.68 & & & & \\
\hline PGSP0533 & Jul/07/1994 & 11:30 & 2.67 & & & & \\
\hline PGSP0534 & Jul/13/1994 & $6: 00$ & 4.22 & & & & \\
\hline PGSP0535 & Jul/20/1994 & $6: 00$ & 4.45 & & & & \\
\hline PGSP0537 & Jul/25/1994 & $18: 38$ & 4.29 & & & & \\
\hline PGSP0538 & Aug/03/1994 & $8: 30$ & 4.27 & & & & \\
\hline PGSP0539 & Aug/16/1994 & $10: 00$ & 4.16 & & & & \\
\hline PGSP0540 & Sep/08/1994 & $8: 15$ & 3.86 & & & & \\
\hline PGSP0541 & Sep/19/1994 & $13: 50$ & 3.82 & & & & \\
\hline \multicolumn{3}{|r|}{ Average* $^{*}$} & 4.86 & & & & 0.153 \\
\hline \multicolumn{3}{|r|}{ Maximum } & 7.82 & & & & 0.509 \\
\hline \multicolumn{3}{|r|}{ Minimum } & 2.37 & & & & 0.035 \\
\hline \multicolumn{3}{|r|}{ Stand. Dev. } & 1.20 & & & & 0.203 \\
\hline \multicolumn{3}{|r|}{ Coef. Var. } & 0.25 & & & & 1.326 \\
\hline
\end{tabular}

George Delaney swallow hole, October 1993-September 1994

\begin{tabular}{|c|c|c|c|c|c|c|c|}
\hline $\begin{array}{l}\text { Sample } \\
\text { Number }\end{array}$ & Date & Time (CST) & $\begin{array}{c}\text { Total Nitrate- } \\
\text { Nitrogen } \\
\text { (mg/L as } N) \\
\end{array}$ & $\begin{array}{c}\text { Total Nitrite } \\
\left(\mathrm{mg} / \mathrm{L}^{2} \text { as } \mathrm{NO}_{2}{ }^{-}\right)\end{array}$ & $\begin{array}{c}\text { Ammonia } \\
\left(\mathrm{mg} / \mathrm{L} \text { as } \mathrm{NH}_{3}\right)\end{array}$ & $\begin{array}{l}\text { Total Kjeldahl } \\
\text { Nitrogen } \\
\text { (mg/L as } N) \\
\end{array}$ & $\begin{array}{c}\text { Orthophosphate } \\
\text { (mg/L as } \\
\left.\mathrm{PO}_{4}{ }^{-3}\right)\end{array}$ \\
\hline GDSW0012 & $\mathrm{Dec} / 07 / 1993$ & $11: 40$ & 10.40 & & & & \\
\hline GDSW0013 & \begin{tabular}{|l|} 
Mar/28/1994 \\
\end{tabular} & $10: 40$ & 5.69 & & & & \\
\hline GDSW0014 & Apr/07/1994 & $15: 00$ & 7.77 & & & & \\
\hline GDSW0015 & Apr/20/1994 & $12: 10$ & 7.79 & & & & \\
\hline GDSW0016 & Apr/26/1994 & $15: 30$ & 5.35 & & & & \\
\hline GDSW0017 & May/12/1994 & $9: 50$ & 5.72 & & & & \\
\hline GDSW0018 & May/17/1994 & 13:28 & 5.60 & & & & \\
\hline \begin{tabular}{|l|} 
GDSW0019 \\
\end{tabular} & Jun/01/1994 & $7: 36$ & 5.42 & & & & \\
\hline GDSW0020 & Jun/15/1994 & $0: 20$ & 4.70 & & & & \\
\hline GDSW0021 & Jul/06/1994 & $9: 45$ & 4.88 & & & & \\
\hline \multicolumn{3}{|r|}{ Average* } & 6.33 & & & & \\
\hline \multicolumn{3}{|r|}{ Maximum } & 10.40 & & & & \\
\hline \multicolumn{3}{|r|}{ Minimum } & 4.70 & & & & \\
\hline \multicolumn{3}{|r|}{ Stand. Dev. } & 1.78 & & & & \\
\hline \multicolumn{3}{|r|}{ Coef. Var. } & 0.28 & & & & \\
\hline
\end{tabular}

*These statistics are presented as a descriptive summary of the table. The effects of aliasing and variable sampling intervals may significantly affect the validity of averages presented as representative of ground-water quality in the basin. No data means an analysis was not performed. 
Leslie Page karst window, October 1993-September 1994

\begin{tabular}{|c|c|c|c|c|c|c|c|}
\hline $\begin{array}{l}\text { Sample } \\
\text { Number }\end{array}$ & Date & Time (CST) & $\begin{array}{l}\text { Total Nitrate- } \\
\text { Nitrogen } \\
\text { (mg/L as N) }\end{array}$ & $\begin{array}{c}\text { Total Nitrite } \\
\left(\mathrm{mg} / \mathrm{L} \text { as } \mathrm{NO}_{2}^{-}\right) \\
\end{array}$ & $\begin{array}{c}\text { Ammonia } \\
\left(\mathrm{mg} / \mathrm{L} \text { as } \mathrm{NH}_{3}\right)\end{array}$ & $\begin{array}{l}\text { Total Kjeldahl } \\
\text { Nitrogen } \\
\text { (mg/L as N) }\end{array}$ & $\begin{array}{c}\text { Orthophosphate } \\
(\mathrm{mg} / \mathrm{L} \text { as } \\
\left.\mathrm{PO}_{4}{ }^{-3}\right) \\
\end{array}$ \\
\hline LPKW0020 & Nov/09/1993 & $9: 35$ & 5.42 & & & & \\
\hline LPKW0021 & Dec/07/1993 & $16: 53$ & 5.90 & & & & \\
\hline LPKW0022 & \begin{tabular}{|l|}
$J a n / 11 / 1994$ \\
\end{tabular} & $14: 23$ & 6.37 & & & & \\
\hline LPKW0023 & Feb/02/1994 & $9: 55$ & 7.34 & & & & \\
\hline LPKW0024 & Feb/22/1994 & $13: 30$ & 7.43 & & & & 0.035 \\
\hline LPKW0026 & Mar/10/1994 & 19:23 & 8.79 & & & & \\
\hline LPKW0027 & Mar/10/1994 & 19:43 & 8.22 & & & & \\
\hline LPKW0028 & Mar/10/1994 & $20: 03$ & 8.09 & & & & \\
\hline LPKW0029 & Mar/10/1994 & $20: 23$ & 8.20 & & & & \\
\hline LPKW0030 & Mar/10/1994 & $20: 43$ & 8.22 & & & & \\
\hline LPKW0031 & Mar/10/1994 & $21: 03$ & 8.09 & & & & \\
\hline \begin{tabular}{|l} 
LPKW0032 \\
\end{tabular} & Mar/10/1994 & $21: 23$ & 8.79 & & & & \\
\hline LPKW0033 & Mar/10/1994 & $21: 43$ & 7.88 & & & & \\
\hline LPKW0034 & Mar/10/1994 & $22: 03$ & 7.86 & & & & \\
\hline LPKW0035 & \begin{tabular}{|l|}
$\operatorname{Mar} / 10 / 1994$ \\
\end{tabular} & $22: 23$ & 7.88 & & & & \\
\hline LPKW0036 & Mar/10/1994 & $23: 23$ & 7.86 & & & & \\
\hline LPKW0037 & Mar/11/1994 & $0: 23$ & 8.49 & & & & \\
\hline LPKW0038 & Mar/11/1994 & $1: 23$ & 7.91 & & & & \\
\hline LPKW0039 & Mar/11/1994 & $2: 23$ & 8.02 & & & & \\
\hline LPKW0040 & \begin{tabular}{|l|}
$\operatorname{Mar} / 11 / 1994$ \\
\end{tabular} & $3: 23$ & 7.95 & & & & \\
\hline LPKW0041 & Mar/11/1994 & $4: 23$ & 8.65 & & & & \\
\hline LPKW0042 & Mar/11/1994 & $5: 23$ & 8.02 & & & & \\
\hline LPKW0043 & Mar/11/1994 & $6: 23$ & 8.02 & & & & \\
\hline \begin{tabular}{|l} 
LPKW 0044 \\
\end{tabular} & Mar/11/1994 & $7: 23$ & 8.18 & & & & \\
\hline LPKW0045 & Mar/11/1994 & $8: 23$ & 8.65 & & & & \\
\hline LPKW0046 & Mar/11/1994 & $12: 23$ & 8.63 & & & & \\
\hline LPKW0047 & \begin{tabular}{|l|}
$\operatorname{Mar} / 11 / 1994$ \\
\end{tabular} & $16: 23$ & 8.61 & & & & \\
\hline LPKW0048 & Mar/11/1994 & $20: 23$ & 8.72 & & & & \\
\hline LPKW0049 & Mar/12/1994 & $0: 23$ & 8.67 & & & & \\
\hline LPKW0050 & Mar/15/1994 & $17: 10$ & 7.70 & & & & \\
\hline LPKW0051 & Mar/27/1994 & $15: 50$ & 7.32 & & & & \\
\hline LPKW0052 & \begin{tabular}{|l|}
$\operatorname{Mar} / 28 / 1994$ \\
\end{tabular} & $9: 10$ & 7.79 & & & & \\
\hline LPKW0053 & Mar/28/1994 & $9: 30$ & 6.75 & & & & \\
\hline LPKW0054 & \begin{tabular}{|l|}
$\operatorname{Mar} / 28 / 1994$ \\
\end{tabular} & $9: 50$ & 7.68 & & & & \\
\hline LPKW0055 & Mar/28/1994 & $10: 10$ & 7.86 & & & & \\
\hline LPKW0056 & \begin{tabular}{|l|}
$\operatorname{Mar} / 28 / 1994$ \\
\end{tabular} & $10: 30$ & 7.61 & & & & \\
\hline LPKW0057 & Mar/28/1994 & $10: 50$ & 7.86 & & & & \\
\hline LPKW0058 & \begin{tabular}{|l|}
$\operatorname{Mar} / 28 / 1994$ \\
\end{tabular} & $11: 10$ & 7.77 & & & & \\
\hline LPKW0059 & \begin{tabular}{|l|}
$\operatorname{Mar} / 28 / 1994$ \\
\end{tabular} & $11: 30$ & 7.55 & & & & \\
\hline LPKW0060 & Mar/28/1994 & $11: 50$ & 7.59 & & & & \\
\hline LPKW0061 & \begin{tabular}{|l|}
$\operatorname{Mar} / 28 / 1994$ \\
\end{tabular} & $12: 10$ & 7.73 & & & & \\
\hline \begin{tabular}{|l|l|} 
LPKW062 \\
\end{tabular} & Mar/28/1994 & $12: 30$ & 7.73 & & & & \\
\hline LPKW0063 & Mar/28/1994 & $13: 30$ & 7.59 & & & & \\
\hline LPKW0064 & \begin{tabular}{|l|}
$\operatorname{Mar} / 28 / 1994$ \\
\end{tabular} & $14: 30$ & 7.88 & & & & \\
\hline LPKW0065 & Mar/28/1994 & $15: 30$ & 7.93 & & & & \\
\hline LPKW0066 & \begin{tabular}{|l|}
$\operatorname{Mar} / 28 / 1994$ \\
\end{tabular} & 16:30 & 7.75 & & & & \\
\hline LPKW0067 & Mar/28/1994 & $17: 30$ & 7.79 & & & & \\
\hline LPKW0068 & \begin{tabular}{|l|}
$\operatorname{Mar} / 28 / 1994$ \\
\end{tabular} & 18:30 & 7.86 & & & & \\
\hline LPKW0069 & Mar/28/1994 & 19:30 & 7.68 & & & & \\
\hline LPKW0070 & \begin{tabular}{|l|}
$\operatorname{Mar} / 28 / 1994$ \\
\end{tabular} & $20: 30$ & 7.73 & & & & \\
\hline \begin{tabular}{|l|} 
LPKW071 \\
\end{tabular} & Mar/28/1994 & $21: 30$ & 7.77 & & & & \\
\hline LPKW0072 & Mar/28/1994 & $22: 30$ & 7.79 & & & & \\
\hline LPKW0073 & Mar/29/1994 & $2: 30$ & 7.86 & & & & \\
\hline LPKW0074 & Mar/29/1994 & $6: 30$ & 7.84 & & & & \\
\hline
\end{tabular}

*These statistics are presented as a descriptive summary of the table. The effects of aliasing and variable sampling intervals may significantly affect the validity of averages presented as representative of ground-water quality in the basin. No data means an analysis was not performed. 
Leslie Page karst window, October 1993-September 1994

\begin{tabular}{|c|c|c|c|c|c|c|c|}
\hline $\begin{array}{l}\text { Sample } \\
\text { Number }\end{array}$ & Date & Time (CST) & $\begin{array}{l}\text { Total Nitrate- } \\
\text { Nitrogen } \\
\text { (mg/L as } N \text { ) }\end{array}$ & $\begin{array}{c}\text { Total Nitrite } \\
\left(\mathrm{mg} / \mathrm{L}_{\text {as }} \mathrm{NO}_{2}{ }^{-}\right)\end{array}$ & $\begin{array}{c}\text { Ammonia } \\
\left(\mathrm{mg} / \mathrm{L} \text { as } \mathrm{NH}_{3}\right)\end{array}$ & $\begin{array}{l}\text { Total Kjeldahl } \\
\text { Nitrogen } \\
\text { (mg/L as } N)\end{array}$ & $\begin{array}{c}\text { Orthophosphate } \\
\qquad \begin{array}{c}(\mathrm{mg} / \mathrm{L} \text { as } \\
\left.\mathrm{PO}_{4}{ }^{-3}\right)\end{array}\end{array}$ \\
\hline LPKW0075 & Mar/29/1994 & $10: 30$ & 7.88 & & & & \\
\hline LPKW0076 & Mar/29/1994 & $14: 30$ & 7.59 & & & & \\
\hline LPKW0077 & Apr/07/1994 & $10: 55$ & 6.94 & & & & \\
\hline LPKW0078 & Apr/12/1994 & $8: 06$ & 8.38 & & & & \\
\hline LPKW0079 & Apr/20/1994 & $8: 15$ & 7.52 & & & & \\
\hline LPKW0080 & Apr/27/1994 & $8: 31$ & 4.54 & & & & \\
\hline LPKW0081 & May/02/1994 & $12: 23$ & 5.20 & & & & \\
\hline LPKW0082 & May/03/1994 & $6: 00$ & 5.04 & & & & \\
\hline LPKW0083 & May/04/1994 & $6: 00$ & 5.01 & & & & \\
\hline LPKW0088 & May/09/1994 & $6: 00$ & 5.35 & & & & \\
\hline LPKW0089 & May/11/1994 & $6: 00$ & 5.33 & & & & \\
\hline LPKW0090 & May/12/1994 & $10: 40$ & 5.31 & & & & \\
\hline LPKW0091 & May/13/1994 & $6: 00$ & 5.42 & & & & \\
\hline LPKW0092 & May/14/1994 & $6: 00$ & 5.33 & & & & \\
\hline LPKW0093 & May/15/1994 & $6: 00$ & 5.31 & & & & \\
\hline LPKW0094 & May/16/1994 & $6: 00$ & 5.24 & & & & \\
\hline LPKW0095 & May/17/1994 & $6: 00$ & 5.33 & & & & \\
\hline LPKW0096 & May/18/1994 & $6: 00$ & 5.26 & & & & \\
\hline LPKW0097 & May/20/1994 & $6: 00$ & 5.15 & & & & \\
\hline LPKW0098 & May/22/1994 & $6: 00$ & 5.15 & & & & \\
\hline LPKW0099 & May/24/1994 & $6: 00$ & 5.15 & & & & \\
\hline LPKW0100 & May/25/1994 & $10: 45$ & 5.04 & & & & \\
\hline LPKW0101 & May/27/1994 & $10: 45$ & 5.13 & & & & \\
\hline LPKW0102 & May/29/1994 & $10: 45$ & 5.01 & & & & \\
\hline LPKW0103 & May/31/1994 & $10: 45$ & 4.92 & & & & \\
\hline LPKW0104 & Jun/01/1994 & $8: 30$ & 4.72 & & & & \\
\hline LPKW0105 & Jun/15/1994 & $11: 35$ & 4.92 & & & & \\
\hline LPKW0106 & Jun/27/1994 & $23: 50$ & 4.77 & & & & \\
\hline LPKW0107 & Jun/28/1994 & $7: 50$ & 4.54 & & & & \\
\hline LPKW0108 & Jun/29/1994 & $7: 50$ & 4.61 & & & & \\
\hline LPKW0109 & Aug/02/1994 & $14: 20$ & 4.31 & & & & \\
\hline LPKW0110 & Sep/07/1994 & $12: 50$ & 4.18 & & & & \\
\hline & & Average* & 6.90 & & & & \\
\hline & & Maximum & 8.79 & & & & \\
\hline & & Minimum & 4.18 & & & & \\
\hline & & Stand. Dev. & 1.50 & & & & \\
\hline & & Coef. Var. & 0.22 & & & & \\
\hline
\end{tabular}

*These statistics are presented as a descriptive summary of the table. The effects of aliasing and variable sampling intervals may significantly affect the validity of averages presented as representative of ground-water quality in the basin. No data means an analysis was not performed. 
Upper Pleasant Grove Creek, October 1993-September 1994

\begin{tabular}{|c|c|c|c|c|c|c|c|}
\hline $\begin{array}{l}\text { Sample } \\
\text { Number }\end{array}$ & Date & Time (CST) & $\begin{array}{c}\text { Total Nitrate- } \\
\text { Nitrogen } \\
\text { (mg/L as } N) \\
\end{array}$ & $\begin{array}{c}\text { Total Nitrite } \\
\left(\mathrm{mg} / \mathrm{L} \text { as } \mathrm{NO}_{2}{ }^{-}\right)\end{array}$ & $\begin{array}{c}\text { Ammonia } \\
\left(m g / L \text { as } \mathrm{NH}_{3}\right) \\
\end{array}$ & $\begin{array}{c}\text { Total Kjeldahl } \\
\text { Nitrogen } \\
\text { (mg/L as } N) \\
\end{array}$ & $\begin{array}{c}\text { Orthophosphate } \\
\text { (mg/L as } \\
\left.\mathrm{PO}_{4}{ }^{-3}\right)\end{array}$ \\
\hline UPGC0004 & Nov/18/1993 & $11: 31$ & 8.43 & & & & \\
\hline UPGC0005 & $\mathrm{Dec} / 07 / 1993$ & $15: 10$ & 10.80 & & & & \\
\hline UPGC0006 & Feb/22/1994 & $15: 16$ & 7.30 & & & & \\
\hline UPGC0007 & Mar/28/1994 & $11: 05$ & 5.60 & & & & \\
\hline UPGC0008 & Apr/07/1994 & $10: 25$ & 8.04 & & & & \\
\hline UPGC0009 & Apr/20/1994 & $12: 25$ & 7.77 & & & & \\
\hline UPGC0010 & Apr/27/1994 & $7: 10$ & 5.62 & & & & \\
\hline UPGC0011 & May/12/1994 & $10: 10$ & 6.01 & & & & \\
\hline UPGC0012 & May/17/1994 & $12: 13$ & 5.65 & & & & \\
\hline UPGC0013 & Jun/01/1994 & $7: 07$ & 6.96 & & & & \\
\hline UPGC0014 & Jun/15/1994 & 11:00 & 7.39 & & & & \\
\hline UPGC0015 & Jul/06/1994 & $7: 30$ & 6.73 & & & & \\
\hline \multicolumn{3}{|r|}{ Average $^{*}$} & 7.19 & & & & \\
\hline \multicolumn{3}{|r|}{ Maximum } & 10.80 & & & & \\
\hline \multicolumn{3}{|r|}{ Minimum } & 5.60 & & & & \\
\hline \multicolumn{3}{|r|}{ Stand. Dev. } & 1.50 & & & & \\
\hline \multicolumn{3}{|r|}{ Coef. Var. } & 0.21 & & & & \\
\hline
\end{tabular}

Miller School House water well, October 1993-September 1994

\begin{tabular}{|c|c|c|c|c|c|c|c|}
\hline $\begin{array}{l}\text { Sample } \\
\text { Number }\end{array}$ & Date & Time (CST) & $\begin{array}{l}\text { Total Nitrate- } \\
\text { Nitrogen } \\
\text { (mg/L as } N)\end{array}$ & $\begin{array}{c}\text { Total Nitrite } \\
\left(\mathrm{mg} / \mathrm{L}_{\text {as }} \mathrm{NO}_{2}{ }^{-}\right)\end{array}$ & $\begin{array}{c}\text { Ammonia } \\
\left(\mathrm{mg} / \mathrm{L} \text { as } \mathrm{NH}_{3}\right)\end{array}$ & $\begin{array}{l}\text { Total Kjeldahl } \\
\text { Nitrogen } \\
\text { (mg/L as } N)\end{array}$ & $\begin{array}{c}\text { Orthophosphate } \\
\text { (mg/L as } \\
\left.\mathrm{PO}_{4}^{-3}\right)\end{array}$ \\
\hline MSHW0001 & Apr/26/1994 & $14: 00$ & 1.45 & & & & 0.766 \\
\hline
\end{tabular}

*These statistics are presented as a descriptive summary of the table. The effects of aliasing and variable sampling intervals may significantly affect the validity of averages presented as representative of ground-water quality in the basin. No data means an analysis was not performed. 
Pleasant Grove Spring, October 1993-September 1994

\begin{tabular}{|c|c|c|c|c|c|c|}
\hline $\begin{array}{l}\text { Sample } \\
\text { Number }\end{array}$ & $\begin{array}{c}\text { Laboratory } \\
\mathrm{pH}\end{array}$ & $\begin{array}{c}\text { Laboratory } \\
\text { Specific } \\
\text { Conductance } \\
\left.\text { (at } 25^{\circ} \mathrm{C}\right)(\mu S)\end{array}$ & $\begin{array}{c}\text { Total } \\
\text { Alkalinity } \\
\text { (mg/L as } \\
\text { CaCO3) }\end{array}$ & $\begin{array}{c}\text { Dissolved Solids } \\
\text { Residue on } \\
\text { Evaporation } \\
\left(\mathrm{mg} / \mathrm{L} 180^{\circ} \mathrm{C}\right)\end{array}$ & \begin{tabular}{|} 
Suspended \\
Solids Residue \\
on Evaporation \\
( $\left.\mathrm{mg} / \mathrm{L} 180^{\circ} \mathrm{C}\right)$
\end{tabular} & $\begin{array}{c}\text { Total Iron } \\
(m g / L \text { as } F e)\end{array}$ \\
\hline PGSP0303 & 6.82 & 503 & & 296 & 5 & 0.048 \\
\hline PGSP0304 & 7.36 & 508 & & 302 & 4 & 0.006 \\
\hline PGSP0307 & & & & 276 & 7 & \\
\hline PGSP0312 & & & & 278 & 17 & \\
\hline PGSP0317 & & & & 278 & 205 & \\
\hline PGSP0326 & & & & 258 & 14 & \\
\hline PGSP0328 & & & & 256 & 8 & \\
\hline PGSP0330 & & & & 260 & 3 & \\
\hline PGSP0335 & & & & 144 & 44 & \\
\hline PGSP0336 & & & & 178 & 143 & \\
\hline PGSP0337 & & & & 156 & 51 & \\
\hline PGSP0338 & & & & 152 & 293 & \\
\hline PGSP0339 & & & & 174 & 123 & \\
\hline PGSP0340 & & & & 206 & 98 & \\
\hline PGSP0341 & & & & 218 & 65 & \\
\hline PGSP0343 & 6.75 & 352 & & 222 & 44 & 0.857 \\
\hline PGSP0345 & & & & 140 & 140 & \\
\hline PGSP0346 & & & & 196 & 196 & \\
\hline PGSP0347 & & & & 226 & 176 & \\
\hline PGSP0349 & & & & 180 & 527 & \\
\hline PGSP0350 & & & & 212 & 427 & \\
\hline PGSP0351 & & & & 220 & 373 & \\
\hline PGSP0352 & & & & 206 & 255 & \\
\hline PGSP0353 & & & & 186 & 214 & \\
\hline PGSP0355 & & & & 198 & 186 & \\
\hline PGSP0356 & & & & 186 & 159 & \\
\hline PGSP0357 & & & & 204 & 147 & \\
\hline PGSP0358 & & & & 210 & 192 & \\
\hline PGSP0359 & & & & 128 & 153 & \\
\hline PGSP0360 & & & & 162 & 163 & \\
\hline PGSP0361 & & & & 184 & 127 & \\
\hline PGSP0362 & & & & 180 & 59 & \\
\hline PGSP0363 & & & & 180 & 67 & \\
\hline PGSP0364 & & & & 250 & 85 & \\
\hline PGSP0365 & & & & 204 & 75 & 2.360 \\
\hline PGSP0366 & & & & 228 & 40 & \\
\hline PGSP0367 & & & & 216 & 52 & \\
\hline PGSP0368 & & & & 228 & 46 & \\
\hline PGSP0369 & & & & 228 & 38 & \\
\hline PGSP0370 & & & & 222 & 33 & \\
\hline PGSP0371 & & & & 230 & 32 & \\
\hline PGSP0372 & & & & 228 & 29 & \\
\hline PGSP0373 & & & & 332 & 28 & \\
\hline PGSP0374 & & & & 238 & 36 & \\
\hline PGSP0375 & & & & 244 & 29 & \\
\hline PGSP0376 & & & & 224 & 27 & \\
\hline
\end{tabular}


Pleasant Grove Spring, October 1993-September 1994

\begin{tabular}{|c|c|c|c|c|c|c|}
\hline $\begin{array}{l}\text { Sample } \\
\text { Number }\end{array}$ & $\begin{array}{c}\text { Laboratory } \\
\mathrm{pH}\end{array}$ & $\begin{array}{c}\text { Laboratory } \\
\text { Specific } \\
\text { Conductance } \\
\left(\text { at } 25^{\circ} \mathrm{C}\right)(\mu \mathrm{S})\end{array}$ & $\begin{array}{c}\text { Total } \\
\text { Alkalinity } \\
\text { (mg/L as } \\
\text { CaCO3) }\end{array}$ & $\begin{array}{c}\text { Dissolved Solids } \\
\text { Residue on } \\
\text { Evaporation } \\
\left(\mathrm{mg} / \mathrm{L} 180^{\circ} \mathrm{C}\right)\end{array}$ & $\begin{array}{c}\text { Suspended } \\
\text { Solids Residue } \\
\text { on Evaporation } \\
\left(\mathrm{mg} / \mathrm{L} 180^{\circ} \mathrm{C}\right)\end{array}$ & $\begin{array}{c}\text { Total Iron } \\
(m g / L \text { as } F e)\end{array}$ \\
\hline PGSP0377 & & & & 248 & 33 & \\
\hline PGSP0378 & & & & 238 & 24 & \\
\hline PGSP0379 & & & & 186 & 23 & \\
\hline PGSP0380 & & & & 182 & 24 & \\
\hline PGSP0381 & & & & 188 & 24 & \\
\hline PGSP0382 & & & & 166 & 37 & \\
\hline PGSP0383 & & & & 174 & 31 & \\
\hline PGSP0384 & & & & 180 & 19 & \\
\hline PGSP0387 & & & & 162 & & \\
\hline PGSP0388 & & & & 178 & & \\
\hline PGSP0389 & & & & 202 & & \\
\hline PGSP0391 & & & & 200 & & \\
\hline PGSP0392 & & & & 206 & & \\
\hline PGSP0393 & & & & 232 & 139 & \\
\hline PGSP0394 & & & & 238 & 93 & \\
\hline PGSP0395 & & & & 234 & 67 & \\
\hline PGSP0396 & & & & 212 & 90 & \\
\hline PGSP0397 & & & & 202 & 290 & \\
\hline PGSP0398 & & & & 222 & 81 & \\
\hline PGSP0399 & & & & 220 & 44 & \\
\hline PGSP0400 & & & & 218 & 52 & \\
\hline PGSP0401 & & & & 250 & 47 & \\
\hline PGSP0402 & & & & 236 & 46 & \\
\hline PGSP0403 & & & & 242 & 49 & \\
\hline PGSP0404 & & & & 234 & 45 & \\
\hline PGSP0412 & 7.20 & 356 & & 216 & 4 & 0.419 \\
\hline PGSP0416 & & & & 244 & 99 & \\
\hline PGSP0417 & & & & 240 & 98 & \\
\hline PGSP0418 & & & & 242 & 101 & \\
\hline PGSP0419 & & & & 244 & 94 & \\
\hline PGSP0420 & & & & 232 & 94 & \\
\hline PGSP0421 & & & & 244 & 107 & \\
\hline PGSP0422 & & & & 248 & 120 & \\
\hline PGSP0423 & & & & 242 & 146 & \\
\hline PGSP0424 & & & & 238 & 224 & \\
\hline PGSP0425 & & & & 280 & 299 & \\
\hline PGSP0426 & & & & 274 & 391 & \\
\hline PGSP0427 & & & & 262 & 518 & \\
\hline PGSP0428 & & & & 230 & 1827 & \\
\hline PGSP0429 & & & & 204 & 2278 & \\
\hline PGSP0430 & & & & 212 & 1700 & \\
\hline PGSP0431 & & & & 210 & 1061 & \\
\hline PGSP0432 & & & & 186 & 682 & \\
\hline PGSP0433 & & & & 230 & 478 & \\
\hline PGSP0434 & & & & 226 & 421 & \\
\hline PGSP0435 & & & & 200 & 407 & \\
\hline
\end{tabular}


Pleasant Grove Spring, October 1993-September 1994

\begin{tabular}{|c|c|c|c|c|c|c|}
\hline $\begin{array}{l}\text { Sample } \\
\text { Number }\end{array}$ & $\begin{array}{c}\text { Laboratory } \\
\mathrm{pH}\end{array}$ & $\begin{array}{c}\text { Laboratory } \\
\text { Specific } \\
\text { Conductance } \\
\left.\text { (at } 25^{\circ} \mathrm{C}\right)(\mu S)\end{array}$ & $\begin{array}{c}\text { Total } \\
\text { Alkalinity } \\
\text { (mg/L as } \\
\text { CaCO3) }\end{array}$ & $\begin{array}{c}\text { Dissolved Solids } \\
\text { Residue on } \\
\text { Evaporation } \\
\left(\mathrm{mg} / \mathrm{L} 180^{\circ} \mathrm{C}\right)\end{array}$ & $\begin{array}{c}\text { Suspended } \\
\text { Solids Residue } \\
\text { on Evaporation } \\
\left(\mathrm{mg} / \mathrm{L} 180^{\circ} \mathrm{C}\right)\end{array}$ & $\begin{array}{c}\text { Total Iron } \\
\text { (mg/L as Fe) }\end{array}$ \\
\hline PGSP0436 & & & & 202 & 318 & \\
\hline PGSP0437 & & & & 218 & 272 & \\
\hline PGSP0438 & & & & 286 & 138 & \\
\hline PGSP0439 & & & & 242 & 74 & \\
\hline PGSP0443 & & & & 254 & 33 & \\
\hline PGSP0445 & & & & & 28 & \\
\hline PGSP0448 & & & & & 20 & \\
\hline PGSP0469 & & & & 236 & 28 & \\
\hline PGSP0470 & & & & 226 & 15 & \\
\hline PGSP0471 & & & & 240 & 15 & \\
\hline PGSP0472 & & & & 128 & 11 & \\
\hline PGSP0473 & & & & 210 & 11 & \\
\hline PGSP0474 & & & & 242 & 10 & \\
\hline PGSP0475 & & & & 234 & 10 & \\
\hline PGSP0476 & & & & 242 & 9 & \\
\hline PGSP0477 & & & & 248 & 10 & \\
\hline PGSP0478 & & & & 232 & 13 & \\
\hline PGSP0479 & & & & 246 & 15 & \\
\hline PGSP0480 & & & & 242 & 14 & \\
\hline PGSP0481 & & & & 262 & 11 & \\
\hline PGSP0482 & & & & 250 & 13 & \\
\hline PGSP0483 & & & & 262 & 12 & \\
\hline PGSP0484 & & & & 284 & 6 & \\
\hline PGSP0485 & & & & 270 & 20 & \\
\hline PGSP0486 & & & & 268 & 6 & \\
\hline PGSP0487 & & & & 240 & 16 & \\
\hline PGSP0488 & & & & 256 & 24 & \\
\hline PGSP0491 & & & & 272 & 13 & \\
\hline PGSP0492 & & & & 276 & 11 & \\
\hline PGSP0493 & & & & 280 & 22 & \\
\hline PGSP0497 & & & & 210 & 45 & \\
\hline PGSP0498 & & & & 218 & 30 & \\
\hline PGSP0499 & & & & 222 & 29 & \\
\hline PGSP0500 & & & & 216 & 56 & \\
\hline PGSP0501 & & & & 406 & 97 & \\
\hline PGSP0502 & & & & 228 & 123 & \\
\hline PGSP0503 & & & & 236 & 165 & \\
\hline PGSP0504 & & & & 234 & 15 & \\
\hline PGSP0505 & & & & 250 & 3 & \\
\hline PGSP0506 & & & & 264 & 226 & \\
\hline PGSP0507 & & & & 254 & 373 & \\
\hline PGSP0508 & & & & 178 & 706 & \\
\hline PGSP0509 & & & & 134 & 951 & \\
\hline PGSP0510 & & & & 132 & 764 & \\
\hline PGSP0511 & & & & 130 & 621 & \\
\hline
\end{tabular}


Pleasant Grove Spring, October 1993-September 1994

\begin{tabular}{|c|c|c|c|c|c|c|}
\hline $\begin{array}{l}\text { Sample } \\
\text { Number }\end{array}$ & $\begin{array}{c}\text { Laboratory } \\
\mathrm{pH}\end{array}$ & $\begin{array}{c}\text { Laboratory } \\
\quad \text { Specific } \\
\text { Conductance } \\
\left(\text { at } 25^{\circ} \mathrm{C}\right)(\mu S)\end{array}$ & $\begin{array}{c}\text { Total } \\
\text { Alkalinity } \\
\text { (mg/L as } \\
\text { CaCO3) }\end{array}$ & $\begin{array}{c}\text { Dissolved Solids } \\
\text { Residue on } \\
\text { Evaporation } \\
\left.\text { (mg/ } 180^{\circ} \mathrm{C}\right)\end{array}$ & $\begin{array}{c}\text { Suspended } \\
\text { Solids Residue } \\
\text { on Evaporation } \\
\left(\mathrm{mg} / \mathrm{L} 180^{\circ} \mathrm{C}\right)\end{array}$ & $\begin{array}{c}\text { Total Iron } \\
(\mathrm{mg} / \mathrm{L} \text { as } \mathrm{Fe})\end{array}$ \\
\hline PGSP0512 & & & & 142 & 540 & \\
\hline PGSP0513 & & & & 150 & 364 & \\
\hline PGSP0514 & & & & 142 & 321 & \\
\hline PGSP0515 & & & & 146 & 271 & \\
\hline PGSP0516 & & & & 150 & 210 & \\
\hline PGSP0517 & & & & 164 & 123 & \\
\hline PGSP0518 & & & & 178 & 91 & \\
\hline PGSP0519 & & & & 176 & 71 & \\
\hline PGSP0520 & & & & 200 & 67 & \\
\hline Average* & $\overline{7.03}$ & 430 & & $\overline{2222}$ & 179.32 & 0.738 \\
\hline Maximum & 7.36 & 508 & & 406 & 2,278 & 2.360 \\
\hline Minimum & 6.75 & 352 & & 128 & 3 & 0.006 \\
\hline Stand. Dev. & 0.29 & 87.5 & & 57.7 & 326.43 & 0.969 \\
\hline Coef. Var. & 0.04 & 0.2 & & 0.3 & 1.82 & 1.314 \\
\hline
\end{tabular}

Leslie Page karst window, October 1993-September 1994

\begin{tabular}{|c|c|c|c|c|c|c|}
\hline $\begin{array}{l}\text { Sample } \\
\text { Number }\end{array}$ & $\begin{array}{c}\text { Laboratory } \\
\mathrm{pH}\end{array}$ & $\begin{array}{l}\text { Laboratory } \\
\text { Specific } \\
\text { Conductance } \\
\left.\text { (at } 25^{\circ} \mathrm{C}\right)(\mu S)\end{array}$ & $\begin{array}{c}\text { Total } \\
\text { Alkalinity } \\
\text { (mg/L as } \\
\text { CaCO3) }\end{array}$ & $\begin{array}{c}\text { Dissolved Solids } \\
\text { Residue on } \\
\text { Evaporation } \\
\left.\text { (mg/L } 180^{\circ} \mathrm{C}\right)\end{array}$ & $\begin{array}{c}\text { Suspended } \\
\text { Solids Residue } \\
\text { on Evaporation } \\
\left(\mathrm{mg} / \mathrm{L} 180^{\circ} \mathrm{C}\right)\end{array}$ & $\begin{array}{c}\text { Total Iron } \\
\text { (mg/L as Fe) }\end{array}$ \\
\hline LPKW0024 & 6.17 & 171 & & 104 & 34 & 0.842 \\
\hline LPKW0026 & & & & 62 & 4 & \\
\hline LPKW0027 & & & & 88 & & \\
\hline LPKW0028 & & & & 58 & & \\
\hline LPKW0029 & & & & 66 & & \\
\hline LPKW0030 & & & & 60 & & \\
\hline LPKW0031 & & & & 48 & & \\
\hline LPKW0032 & & & & 74 & 3 & \\
\hline LPKW0033 & & & & 46 & & \\
\hline LPKW0034 & & & & 48 & & \\
\hline LPKW0035 & & & & 50 & & \\
\hline LPKW0036 & & & & 44 & & \\
\hline LPKW0037 & & & & 100 & 3 & \\
\hline LPKW0038 & & & & 32 & & \\
\hline LPKW0040 & & & & 38 & & \\
\hline LPKW0041 & & & & 108 & 3 & \\
\hline LPKW0042 & & & & 34 & & \\
\hline LPKW0043 & & & & 38 & & \\
\hline LPKW0044 & & & & 32 & & \\
\hline LPKW0045 & & & & 102 & 3 & \\
\hline LPKW0046 & & & & 96 & 3 & \\
\hline LPKW0047 & & & & 100 & 3 & \\
\hline
\end{tabular}

*These statistics are presented as a descriptive summary of the table. The effects of aliasing and variable sampling intervals may significantly affect the validity of averages presented as representative of ground-water quality in the basin. No data means an analysis was not performed. 
Leslie Page karst window, October 1993-September 1994

\begin{tabular}{|c|c|c|c|c|c|c|}
\hline $\begin{array}{l}\text { Sample } \\
\text { Number }\end{array}$ & $\begin{array}{c}\text { Laboratory } \\
\mathrm{pH}\end{array}$ & $\begin{array}{c}\text { Laboratory } \\
\text { Specific } \\
\text { Conductance } \\
\left(\text { at } 25^{\circ} \mathrm{C}\right)(\mu \mathrm{S})\end{array}$ & $\begin{array}{c}\text { Total } \\
\text { Alkalinity } \\
\text { (mg/L as } \\
\text { CaCO3) }\end{array}$ & $\begin{array}{c}\text { Dissolved Solids } \\
\text { Residue on } \\
\text { Evaporation } \\
\left(\mathrm{mg} / \mathrm{L} 180^{\circ} \mathrm{C}\right)\end{array}$ & \begin{tabular}{|c|} 
Suspended \\
Solids Residue \\
on Evaporation \\
$\left(\mathrm{mg} / \mathrm{L} 180^{\circ} \mathrm{C}\right)$
\end{tabular} & $\begin{array}{c}\text { Total Iron } \\
(\mathrm{mg} / \mathrm{L} \text { as } \mathrm{Fe})\end{array}$ \\
\hline LPKW0048 & & & & 118 & 3 & \\
\hline LPKW0049 & & & & 84 & 3 & \\
\hline LPKW0050 & & & & 108 & & \\
\hline LPKW0053 & & & & 66 & & \\
\hline LPKW0054 & & & & 90 & & \\
\hline LPKW0055 & & & & 96 & & \\
\hline LPKW0056 & & & & 78 & & \\
\hline LPKW0057 & & & & 88 & & \\
\hline LPKW0058 & & & & 98 & & \\
\hline LPKW0059 & & & & 102 & & \\
\hline LPKW0060 & & & & 102 & & \\
\hline LPKW0061 & & & & 114 & & \\
\hline LPKW0062 & & & & 114 & & \\
\hline LPKW0063 & & & & 108 & & \\
\hline LPKW0064 & & & & 108 & & \\
\hline LPKW0065 & & & & 118 & & \\
\hline LPKW0066 & & & & 114 & & \\
\hline LPKW0067 & & & & 120 & & \\
\hline LPKW0068 & & & & 114 & & \\
\hline LPKW0069 & & & & 56 & & \\
\hline LPKW0070 & & & & 88 & & \\
\hline LPKW0071 & & & & 102 & & \\
\hline LPKW0072 & & & & 76 & & \\
\hline LPKW0073 & & & & 108 & & \\
\hline LPKW0074 & & & & 116 & & \\
\hline LPKW0075 & & & & 116 & & \\
\hline LPKW0076 & & & & 114 & & \\
\hline LPKW0078 & & & & 126 & & \\
\hline Average* & 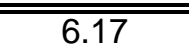 & $\overline{171}$ & & 85 & 6.20 & \\
\hline Maximum & 6.17 & 171 & & 126 & 34 & \\
\hline Minimum & 6.17 & 171 & & 32 & 3 & \\
\hline Stand. Dev. & & & & 28.5 & 9.77 & \\
\hline Coef. Var. & & & & 0.3 & 1.58 & \\
\hline
\end{tabular}

Miller School House water well, October 1993-September 1994

\begin{tabular}{|c|c|c|c|c|c|c|}
\hline $\begin{array}{l}\text { Sample } \\
\text { Number }\end{array}$ & $\begin{array}{c}\text { Laboratory } \\
\mathrm{pH}\end{array}$ & $\begin{array}{c}\text { Laboratory } \\
\text { Specific } \\
\text { Conductance } \\
\left(\text { at } 25^{\circ} \mathrm{C}\right)(\mu S)\end{array}$ & $\begin{array}{c}\text { Total } \\
\text { Alkalinity } \\
\text { (mg/L as } \\
\text { CaCO3) }\end{array}$ & $\begin{array}{c}\text { Dissolved Solids } \\
\text { Residue on } \\
\text { Evaporation } \\
\left(\mathrm{mg} / \mathrm{L} 180^{\circ} \mathrm{C}\right)\end{array}$ & $\begin{array}{c}\text { Suspended } \\
\text { Solids Residue } \\
\text { on Evaporation } \\
\left(\mathrm{mg} / \mathrm{L} 180^{\circ} \mathrm{C}\right)\end{array}$ & $\begin{array}{c}\text { Total Iron } \\
\text { (mg/L as } \mathrm{Fe})\end{array}$ \\
\hline MSHW0001 & 7.51 & 590 & & 350 & 8 & 0.237 \\
\hline
\end{tabular}

*These statistics are presented as a descriptive summary of the table. The effects of aliasing and variable sampling intervals may significantly affect the validity of averages presented as representative of ground-water quality in the basin. No data means an analysis was not performed. 
Pleasant Grove Spring, October 1993-September 1994

\begin{tabular}{|c|c|c|c|c|c|c|c|}
\hline $\begin{array}{l}\text { Sample } \\
\text { Number }\end{array}$ & $\begin{array}{c}\text { Total } \\
\text { Calcium } \\
\text { (mg/L as Ca) }\end{array}$ & $\begin{array}{c}\text { Total } \\
\text { Magnesium } \\
\text { (mg/L as } \mathrm{Mg})\end{array}$ & $\begin{array}{l}\text { Total Sodium } \\
\text { (mg/L as } \mathrm{Na})\end{array}$ & $\begin{array}{c}\text { Total } \\
\text { Potassium } \\
\text { (mg/L as } \mathrm{K})\end{array}$ & $\begin{array}{c}\text { Bicarbonate } \\
(\mathrm{mg} / \mathrm{L} \text { as } \\
\left.\mathrm{HCO}_{3}{ }^{-}\right)\end{array}$ & $\begin{array}{c}\text { Total Sulfate } \\
(\mathrm{mg} / \mathrm{L} \text { as } \\
\left.\mathrm{SO}_{4}^{-2}\right)\end{array}$ & $\begin{array}{c}\text { Dissolved } \\
\text { Chloride } \\
\text { (mg/L as Cl) }\end{array}$ \\
\hline PGSP0303 & 90.20 & 9.22 & 2.37 & 1.21 & 307 & 5.76 & 4.90 \\
\hline PGSP0304 & 92.10 & 9.52 & 2.43 & 1.25 & 308 & 6.24 & 4.98 \\
\hline PGSP0343 & 59.20 & 5.19 & 2.33 & 1.76 & 178 & 6.30 & 6.84 \\
\hline PGSP0364 & 42.60 & 4.26 & 1.71 & 2.65 & 128 & 5.80 & 5.10 \\
\hline PGSP0412 & 60.40 & 5.56 & 2.05 & 1.30 & 190 & 5.10 & 5.30 \\
\hline Average* $^{*}$ & 68.90 & $\overline{6.75}$ & 2.18 & 1.63 & 222.20 & $\overline{5.84}$ & $\overline{\overline{5.42}}$ \\
\hline Maximum & 92.10 & 9.52 & 2.43 & 2.65 & 308 & 6.30 & 6.84 \\
\hline Minimum & 42.60 & 4.26 & 1.71 & 1.21 & 128 & 5.10 & 4.90 \\
\hline Stand. Dev. & 21.51 & 2.44 & 0.30 & 0.61 & 81.27 & 0.48 & 0.81 \\
\hline Coef. Var. & 0.31 & 0.36 & 0.14 & 0.37 & 0.37 & 0.08 & 0.15 \\
\hline
\end{tabular}

Leslie Page karst window, October 1993-September 1994

\begin{tabular}{|c|c|c|c|c|c|c|c|}
\hline $\begin{array}{l}\text { Sample } \\
\text { Number }\end{array}$ & $\begin{array}{c}\text { Total } \\
\text { Calcium } \\
\text { (mg/L as } \mathrm{Ca})\end{array}$ & $\begin{array}{c}\text { Total } \\
\text { Magnesium } \\
\text { (mg/L as } \mathrm{Mg})\end{array}$ & $\begin{array}{l}\text { Total Sodium } \\
\text { ( } \mathrm{mg} / \mathrm{L} \text { as } \mathrm{Na})\end{array}$ & $\begin{array}{c}\text { Total } \\
\text { Potassium } \\
\text { (mg/L as } \mathrm{K})\end{array}$ & $\begin{array}{c}\text { Bicarbonate } \\
\text { (mg/L as } \\
\left.\mathrm{HCO}_{3}{ }^{-}\right)\end{array}$ & $\begin{array}{c}\text { Total Sulfate } \\
\text { (mg/L as } \\
\left.\mathrm{SO}_{4}{ }^{-2}\right)\end{array}$ & $\begin{array}{c}\text { Dissolved } \\
\text { Chloride } \\
\text { (mg/L as Cl) }\end{array}$ \\
\hline LPKW0024 & 23.90 & 2.85 & 2.45 & 1.30 & 63 & 12.90 & 8.32 \\
\hline
\end{tabular}

Miller School House water well, October 1993-September 1994

\begin{tabular}{|c|c|c|c|c|c|c|c|}
\hline $\begin{array}{c}\text { Sample } \\
\text { Number }\end{array}$ & $\begin{array}{c}\text { Total } \\
\text { Calcium } \\
(\mathrm{mg} / \mathrm{L} \text { as } \mathrm{Ca})\end{array}$ & $\begin{array}{c}\text { Total } \\
\text { Magnesium } \\
(\mathrm{mg} / \mathrm{L} \text { as } \mathrm{Mg})\end{array}$ & $\begin{array}{c}\text { Total Sodium } \\
(\mathrm{mg} / \mathrm{L} \text { as } \mathrm{Na})\end{array}$ & $\begin{array}{c}\text { Total } \\
\text { Potassium } \\
(\mathrm{mg} / \mathrm{L} \text { as } \mathrm{K})\end{array}$ & $\begin{array}{c}\text { Bicarbonate } \\
(\mathrm{mg} / \mathrm{L} \text { as } \\
\left.\mathrm{HCO}_{3}^{-}\right)\end{array}$ & $\begin{array}{c}\text { Total Sulfate } \\
(\mathrm{mg} / \mathrm{L} \text { as } \\
\left.\mathrm{SO}_{4}{ }^{-2}\right)\end{array}$ & $\begin{array}{c}\text { Dissolved } \\
\text { Chloride } \\
(\mathrm{mg} / \mathrm{L} \text { as } \mathrm{Cl})\end{array}$ \\
\hline MSHW0001 & 54.80 & 32.00 & 14.60 & 1.21 & 348 & 26.20 & 5.30 \\
\hline \hline
\end{tabular}

${ }^{*}$ These statistics are presented as a descriptive summary of the table. The effects of aliasing and variable sampling intervals may significantly affect the validity of averages presented as representative of ground-water quality in the basin. No data means an analysis was not performed. 
ApPendix H:

Water Sample Analyses and Descriptive Statistics for Samples Collected from Pleasant Grove Spring and Shackelford Spring and Used to Develop Figure 10 
Pleasant Grove Spring

\begin{tabular}{|l|c|c|c|c|c|c|c|}
\hline $\begin{array}{c}\text { Sample } \\
\text { Number } \dagger\end{array}$ & $\begin{array}{c}\text { Total Calcium } \\
(\mathrm{mg} / \mathrm{L} \text { as Ca })\end{array}$ & $\begin{array}{c}\text { Total } \\
\text { Magnesium } \\
(\mathrm{mg} / \mathrm{L} \text { as } \mathrm{Mg})\end{array}$ & $\begin{array}{c}\text { Total Sodium } \\
(\mathrm{mg} / \mathrm{L} \text { as } \mathrm{Na})\end{array}$ & $\begin{array}{c}\text { Total } \\
\text { Potassium } \\
(\mathrm{mg} / \mathrm{L} \text { as } \mathrm{K})\end{array}$ & $\begin{array}{c}\text { Bicarbonate } \\
\left(\mathrm{mg} / \mathrm{L} \text { as } \mathrm{HCO}_{3}\right)\end{array}$ & $\begin{array}{c}\text { Total Sulfate } \\
(\mathrm{mg} / \mathrm{L} \text { as } \\
\left.\text { SO }_{4}\right)\end{array}$ & $\begin{array}{c}\text { Dissolved } \\
\text { Chloride } \\
(\mathrm{mg} / \mathrm{L} \text { as } \mathrm{Cl})\end{array}$ \\
\hline PGSP0003 & 68.20 & 6.15 & 2.21 & 1.12 & 212 & 10.90 & 5.86 \\
\hline PGSP0004 & 65.60 & 5.93 & 2.11 & 1.26 & 195 & 5.62 & 5.18 \\
\hline PGSP0006 & 76.60 & 7.40 & 2.18 & 1.17 & 244 & 5.40 & 5.28 \\
\hline PGSP0007 & 88.00 & 8.46 & 2.26 & 1.15 & 273 & 7.53 & 4.65 \\
\hline PGSP0008 & 85.90 & 8.37 & 2.17 & 1.22 & 283 & 5.82 & 4.33 \\
\hline PGSP0009 & 88.90 & 8.85 & 2.24 & 0.93 & 290 & 6.24 & 4.13 \\
\hline PGSP0010 & 76.90 & 6.58 & 2.46 & 1.77 & 201 & 5.60 & 5.83 \\
\hline PGSP0011 & 76.30 & 6.96 & 2.33 & 0.92 & 232 & 5.53 & 10.30 \\
\hline PGSP0012 & 79.00 & 7.21 & 2.48 & 1.62 & 239 & 6.02 & 6.22 \\
\hline PGSP0013 & 70.70 & 6.17 & 2.40 & 1.20 & 213 & 5.26 & 6.41 \\
\hline PGSP0021 & 78.90 & 7.38 & 2.37 & 1.42 & 239 & 5.18 & 4.87 \\
\hline PGSP0026 & 79.90 & 7.66 & 2.32 & 1.31 & 245 & 5.66 & 5.26 \\
\hline \hline Average & 77.91 & 7.26 & 2.29 & 1.26 & 238.83 & 6.23 & 5.69 \\
\hline Maximum & 88.90 & 8.85 & 2.48 & 1.77 & 290 & 10.90 & 10.30 \\
\hline Minimum & 65.60 & 5.93 & 2.11 & 0.92 & 195 & 5.18 & 4.13 \\
\hline Stand. Dev. & 7.36 & 0.96 & 0.12 & 0.25 & 31.02 & 1.60 & 1.62 \\
\hline Coef. Var. & 0.09 & 0.13 & 0.05 & 0.20 & 0.13 & 0.26 & 0.28 \\
\hline \hline
\end{tabular}

Shackelford Spring

\begin{tabular}{|c|c|c|c|c|c|c|c|}
\hline $\begin{array}{c}\text { Sample } \\
\text { Numbert }\end{array}$ & $\begin{array}{c}\text { Total Calcium } \\
\text { ( } \mathrm{mg} / \mathrm{L} \text { as Ca) }\end{array}$ & $\begin{array}{c}\text { Total } \\
\text { Magnesium } \\
\text { (mg/L as Mg) }\end{array}$ & $\begin{array}{l}\text { Total Sodium } \\
\text { ( } \mathrm{mg} / \mathrm{L} \text { as } \mathrm{Na} \text { ) }\end{array}$ & $\begin{array}{c}\text { Total } \\
\text { Potassium } \\
\text { (mg/L as K) }\end{array}$ & $\begin{array}{c}\text { Bicarbonate } \\
\left(\mathrm{mg} / \mathrm{L} \text { as } \mathrm{HCO}_{3}\right)\end{array}$ & $\begin{array}{c}\text { Total Sulfate } \\
\left(\mathrm{mg}^{\prime} \mathrm{L} \text { as }\right. \\
\left.\mathrm{SO}_{4}\right)\end{array}$ & $\begin{array}{l}\text { Dissolved } \\
\text { Chloride } \\
\text { (mg/L as Cl) }\end{array}$ \\
\hline SKSP0003 & 71.30 & 5.54 & 2.87 & 1.10 & 199 & 10.60 & 8.60 \\
\hline SKSP0004 & 72.40 & 5.65 & 2.88 & 0.93 & 198 & 7.11 & 8.67 \\
\hline \begin{tabular}{|l|} 
SKSP0005 \\
\end{tabular} & 75.80 & 5.81 & 3.23 & 1.05 & 205 & 6.04 & 9.45 \\
\hline SKSP0006 & 77.70 & 5.99 & 3.08 & 1.07 & 217 & 12.60 & 9.53 \\
\hline SKSP0007 & 76.30 & 6.00 & 2.96 & 1.18 & 224 & 8.76 & 9.52 \\
\hline SKSP0008 & 78.00 & 6.02 & 3.04 & 0.93 & 232 & 7.40 & 9.29 \\
\hline SKSP0009 & 75.90 & 5.90 & 2.85 & 1.39 & 207 & 6.80 & 8.05 \\
\hline \begin{tabular}{|l|l} 
SKSP0010 \\
\end{tabular} & 76.60 & 5.85 & 3.02 & 1.18 & 208 & 6.44 & 9.72 \\
\hline SKSP0011 & 77.00 & 5.90 & 3.14 & 1.35 & 208 & 7.47 & 9.96 \\
\hline SKSP0012 & 75.80 & 5.85 & 2.95 & 1.20 & 207 & 6.47 & 8.81 \\
\hline SKSP0013 & 76.10 & 5.81 & 3.03 & 1.15 & 206 & 6.33 & 8.80 \\
\hline \begin{tabular}{|l|} 
SKSP0014 \\
\end{tabular} & 75.20 & 5.84 & 3.20 & 1.04 & 211 & 7.32 & 10.00 \\
\hline Average* $^{\star}$ & 75.68 & $\overline{c 5.85}$ & 3.02 & 1.13 & $\overline{20.17}$ & $\overline{c 7.78}$ & 9.20 \\
\hline Maximum & 78.00 & 6.02 & 3.23 & 1.39 & 232 & 12.60 & 10.00 \\
\hline \begin{tabular}{|l|} 
Minimum \\
\end{tabular} & 71.30 & 5.54 & 2.85 & 0.93 & 198 & 6.04 & 8.05 \\
\hline Stand. Dev. & 1.97 & 0.14 & 0.13 & 0.14 & 9.82 & 1.97 & 0.61 \\
\hline Coef. Var. & 0.03 & 0.02 & 0.04 & 0.13 & 0.05 & 0.25 & 0.07 \\
\hline
\end{tabular}

†See Appendix G for collection dates and additional data.

*These statistics are presented as a descriptive summary of the table. The effects of aliasing and variable sampling intervals may significantly affect the validity of averages presented as representative of ground-water quality in the basin. No data means an analysis was not performed. 
Pleasant Grove Spring, October 1990-September 1991

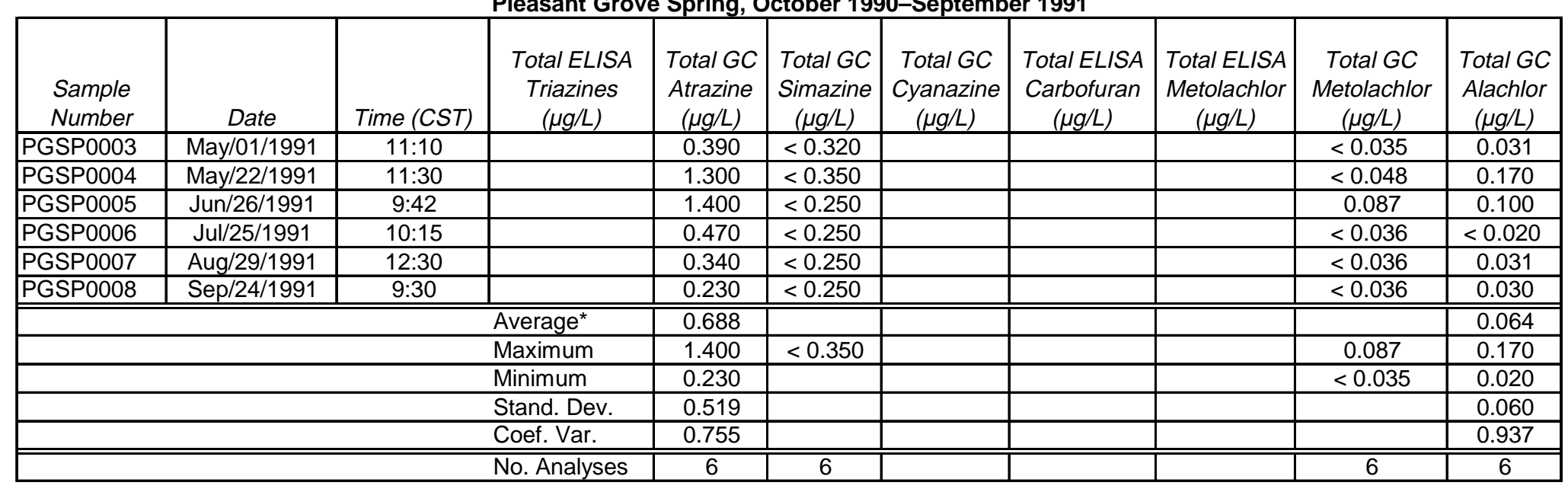

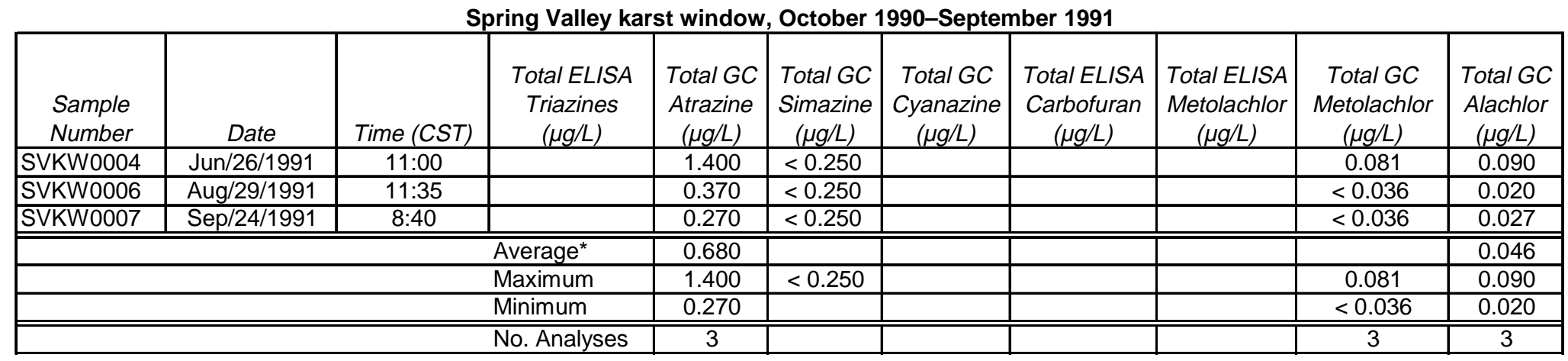

*These statistics are presented as a descriptive summary of the table. The effects of aliasing and variable sampling intervals may significantly affect the validity of averages presented as representative of ground-water quality in the basin. No data means an analysis was not performed. 
The Canyon karst window, October 1990-September 1991

\begin{tabular}{|c|c|c|c|c|c|c|c|c|c|c|}
\hline $\begin{array}{l}\text { Sample } \\
\text { Number }\end{array}$ & Date & Time (CST) & $\begin{array}{c}\text { Total ELISA } \\
\text { Triazines } \\
(\mu \mathrm{g} / \mathrm{L})\end{array}$ & $\begin{array}{c}\text { Total GC } \\
\text { Atrazine } \\
(\mu \mathrm{g} / \mathrm{L})\end{array}$ & $\begin{array}{c}\text { Total GC } \\
\text { Simazine } \\
(\mu g / L)\end{array}$ & $\begin{array}{c}\text { Total GC } \\
\text { Cyanazine } \\
(\mu \mathrm{g} / \mathrm{L})\end{array}$ & $\begin{array}{c}\text { Total ELISA } \\
\text { Carbofuran } \\
(\mu g / L)\end{array}$ & $\begin{array}{c}\text { Total ELISA } \\
\text { Metolachlor } \\
(\mu g / L)\end{array}$ & $\begin{array}{c}\text { Total GC } \\
\text { Metolachlor } \\
(\mu \mathrm{g} / \mathrm{L})\end{array}$ & $\begin{array}{c}\text { Total GC } \\
\text { Alachlor } \\
(\mu \mathrm{g} / \mathrm{L})\end{array}$ \\
\hline TCKW0002 & May/01/1991 & $8: 45$ & & 0.750 & $<0.320$ & & & & $<0.035$ & $<0.022$ \\
\hline TCKW0003 & May/22/1991 & $9: 30$ & & 1.000 & $<0.350$ & & & & $<0.048$ & $<0.022$ \\
\hline TCKW0004 & Jun/26/1991 & $7: 45$ & & 1.100 & $<0.250$ & & & & $<0.036$ & $<0.020$ \\
\hline TCKW0005 & Jul/25/1991 & $8: 24$ & & 0.390 & $<0.250$ & & & & $<0.036$ & $<0.020$ \\
\hline TCKW0006 & Aug/29/1991 & $10: 45$ & & 0.360 & $<0.250$ & & & & $<0.036$ & $<0.020$ \\
\hline TCKW0007 & Sep/24/1991 & $7: 40$ & & 0.230 & $<0.250$ & & & & $<0.036$ & $<0.020$ \\
\hline \multicolumn{4}{|r|}{ Average $^{*}$} & 0.638 & & & & & & \\
\hline \multicolumn{4}{|r|}{ Maximum } & 1.100 & $<0.350$ & & & & $<0.048$ & $<0.022$ \\
\hline \multicolumn{4}{|r|}{ Minimum } & 0.230 & & & & & & \\
\hline \multicolumn{4}{|r|}{ Stand. Dev. } & 0.364 & & & & & & \\
\hline \multicolumn{4}{|r|}{ Coef. Var. } & 0.570 & & & & & & \\
\hline \multicolumn{4}{|r|}{ No. Analyses } & $\overline{c 6}$ & $\overline{c 6}$ & & & & $\overline{6}$ & 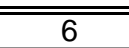 \\
\hline
\end{tabular}

Shackelford Spring, October 1990-September 1991

\begin{tabular}{|c|c|c|c|c|c|c|c|c|c|c|}
\hline $\begin{array}{l}\text { Sample } \\
\text { Number }\end{array}$ & Date & Time (CST) & $\begin{array}{c}\text { Total ELISA } \\
\text { Triazines } \\
(\mu g / L)\end{array}$ & $\begin{array}{c}\text { Total GC } \\
\text { Atrazine } \\
(\mu \mathrm{g} / \mathrm{L})\end{array}$ & $\begin{array}{c}\text { Total GC } \\
\text { Simazine } \\
(\mu g / L)\end{array}$ & $\begin{array}{c}\text { Total GC } \\
\text { Cyanazine } \\
(\mu \mathrm{g} / \mathrm{L})\end{array}$ & $\begin{array}{c}\text { Total ELISA } \\
\text { Carbofuran } \\
(\mu g / L)\end{array}$ & $\begin{array}{c}\text { Total ELISA } \\
\text { Metolachlor } \\
(\mu g / L)\end{array}$ & $\begin{array}{c}\text { Total GC } \\
\text { Metolachlor } \\
(\mu \mathrm{g} / \mathrm{L})\end{array}$ & $\begin{array}{c}\text { Total GC } \\
\text { Alachlor } \\
(\mu g / L)\end{array}$ \\
\hline SKSP0003 & May/01/1991 & $7: 05$ & & 0.720 & $<0.320$ & & & & $<0.035$ & $<0.022$ \\
\hline SKSP0005 & Jul/25/1991 & $7: 20$ & & 0.530 & $<0.250$ & & & & $<0.036$ & $<0.020$ \\
\hline SKSP0006 & Aug/29/1991 & $10: 00$ & & 0.380 & $<0.250$ & & & & $<0.036$ & $<0.020$ \\
\hline SKSP0007 & Sep/24/1991 & $6: 40$ & & 0.310 & $<0.250$ & & & & $<0.036$ & $<0.020$ \\
\hline \multicolumn{4}{|r|}{ Average* $^{*}$} & 0.485 & & & & & & \\
\hline \multicolumn{4}{|r|}{ Maximum } & 0.720 & $<0.320$ & & & & $<0.036$ & $<0.022$ \\
\hline \multicolumn{4}{|r|}{ Minimum } & 0.310 & & & & & & \\
\hline \multicolumn{4}{|r|}{ Stand. Dev. } & 0.182 & & & & & & \\
\hline \multicolumn{4}{|r|}{ Coef. Var. } & 0.374 & & & & & & \\
\hline \multicolumn{4}{|r|}{ No. Analyses } & 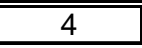 & 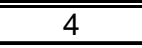 & & & & 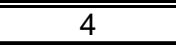 & 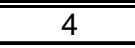 \\
\hline
\end{tabular}

*These statistics are presented as a descriptive summary of the table. The effects of aliasing and variable sampling intervals may significantly affect the validity of averages presented as representative of ground-water quality in the basin. No data means an analysis was not performed. 
Thad Flowers blue hole, October 1990-September 1991

\begin{tabular}{|c|c|c|c|c|c|c|c|c|c|c|}
\hline $\begin{array}{c}\text { Sample } \\
\text { Number }\end{array}$ & Date & Time (CST) & $\begin{array}{c}\text { Total ELISA } \\
\text { Triazines } \\
(\mu g / L)\end{array}$ & $\begin{array}{c}\text { Total GC } \\
\text { Atrazine } \\
(\mu g / L)\end{array}$ & $\begin{array}{c}\text { Total GC } \\
\text { Simazine } \\
(\mu \mathrm{g} / \mathrm{L})\end{array}$ & $\begin{array}{c}\text { Total GC } \\
\text { Cyanazine } \\
(\mu \mathrm{g} / \mathrm{L})\end{array}$ & $\begin{array}{c}\text { Total ELISA } \\
\text { Carbofuran } \\
(\mu g / L)\end{array}$ & $\begin{array}{c}\text { Total ELISA } \\
\text { Metolachlor } \\
(\mu \mathrm{g} / \mathrm{L})\end{array}$ & $\begin{array}{c}\text { Total GC } \\
\text { Metolachlor } \\
(\mu g / L)\end{array}$ & $\begin{array}{c}\text { Total GC } \\
\text { Alachlor } \\
(\mu \mathrm{g} / \mathrm{L})\end{array}$ \\
\hline TFBH0002 & May/01/1991 & $7: 45$ & & 0.570 & $<0.320$ & & & & $<0.035$ & 0.025 \\
\hline TFBH0003 & May/22/1991 & $6: 50$ & & 0.550 & $<0.350$ & & & & $<0.048$ & $<0.022$ \\
\hline TFBH0004 & Jun/26/1991 & $7: 15$ & & 0.590 & $<0.250$ & & & & 0.110 & 0.180 \\
\hline TFBH0005 & Jul/25/1991 & $11: 10$ & & 1.200 & 0.570 & & & & 0.053 & $<0.020$ \\
\hline TFBH0006 & Aug/29/1991 & $9: 25$ & & $<0.160$ & $<0.250$ & & & & $<0.036$ & $<0.020$ \\
\hline & & & Average $^{*}$ & 0.614 & & & & & & \\
\hline & & & Maximum & 1.200 & 0.570 & & & & 0.110 & 0.180 \\
\hline & & & Minimum & 0.160 & $<0.250$ & & & & $<0.035$ & $<0.020$ \\
\hline & & & Stand. Dev. & 0.373 & & & & & & \\
\hline & & & Coef. Var. & 0.607 & & & & & & \\
\hline & & & No. Analyses & 5 & $\overline{5}$ & & & & $\overline{5}$ & $\overline{5}$ \\
\hline
\end{tabular}

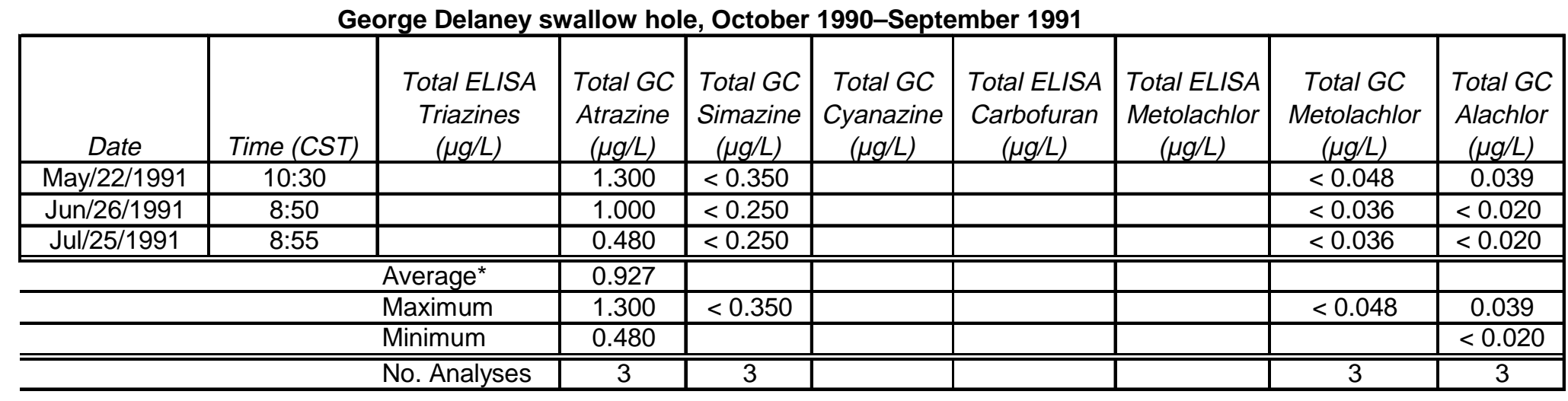

*These statistics are presented as a descriptive summary of the table. The effects of aliasing and variable sampling intervals may significantly affect the validity of averages presented as representative of ground-water quality in the basin. No data means an analysis was not performed. 
Pleasant Grove Spring, October 1991-September 1992

\begin{tabular}{|c|c|c|c|c|c|c|c|c|c|c|}
\hline $\begin{array}{l}\text { Sample } \\
\text { Number }\end{array}$ & Date & Time (CST) & $\begin{array}{c}\text { Total ELISA } \\
\text { Triazines } \\
(\mu g / L)\end{array}$ & $\begin{array}{c}\text { Total GC } \\
\text { Atrazine } \\
(\mu \mathrm{g} / \mathrm{L})\end{array}$ & $\begin{array}{c}\text { Total GC } \\
\text { Simazine } \\
(\mu \mathrm{g} / \mathrm{L})\end{array}$ & $\begin{array}{c}\text { Total GC } \\
\text { Cyanazine } \\
(\mu \mathrm{g} / \mathrm{L})\end{array}$ & $\begin{array}{c}\text { Total ELISA } \\
\text { Carbofuran } \\
(\mu \mathrm{g} / \mathrm{L})\end{array}$ & $\begin{array}{c}\text { Total ELISA } \\
\text { Metolachlor } \\
(\mu g / L)\end{array}$ & $\begin{array}{c}\text { Total GC } \\
\text { Metolachlor } \\
(\mu \mathrm{g} / \mathrm{L})\end{array}$ & $\begin{array}{c}\text { Total GC } \\
\text { Alachlor } \\
(\mu \mathrm{g} / \mathrm{L})\end{array}$ \\
\hline PGSP0009 & Oct/22/1991 & $8: 50$ & & 0.280 & $<0.250$ & & & & $<0.036$ & 0.024 \\
\hline PGSP0010 & Dec/17/1991 & $8: 06$ & & 0.100 & $<0.250$ & & & & $<0.040$ & $<0.018$ \\
\hline PGSP0011 & Jan/29/1992 & $11: 00$ & & 0.290 & 0.590 & & & & $<0.040$ & $<0.018$ \\
\hline PGSP0012 & Feb/26/1992 & $12: 15$ & & 0.250 & 1.100 & & $<0.070$ & & $<0.040$ & $<0.018$ \\
\hline PGSP0013 & Mar/25/1992 & $13: 20$ & & 0.450 & $<0.250$ & & & & $<0.040$ & $<0.018$ \\
\hline PGSP0014 & Apr/01/1992 & $16: 16$ & 0.61 & & & & $<0.070$ & $<0.060$ & & \\
\hline PGSP0015 & Apr/09/1992 & 15:28 & 0.74 & & & & $<0.070$ & $<0.060$ & & \\
\hline PGSP0016 & Apr/16/1992 & $10: 30$ & 0.63 & & & & $<0.070$ & $<0.060$ & & \\
\hline PGSP0017 & Apr/20/1992 & $18: 55$ & 0.58 & & & & $<0.070$ & $<0.060$ & & \\
\hline PGSP0018 & Apr/21/1992 & $8: 30$ & 0.58 & & & & $<0.070$ & $<0.060$ & & \\
\hline PGSP0019 & Apr/21/1992 & $17: 55$ & 1.10 & & & & 0.130 & $<0.060$ & & \\
\hline PGSP0020 & Apr/22/1992 & $7: 37$ & 0.77 & & & & 0.110 & 0.094 & & \\
\hline PGSP0021 & Apr/29/1992 & $9: 40$ & 0.57 & 0.270 & $<0.250$ & & $<0.070$ & & 0.250 & $<0.018$ \\
\hline PGSP0022 & May/07/1992 & $12: 30$ & 0.58 & & & & 0.100 & & $<0.060$ & $<0.060$ \\
\hline PGSP0023 & May/14/1992 & $8: 30$ & 0.49 & & & & $<0.070$ & $<0.060$ & & \\
\hline PGSP0024 & May/20/1992 & $7: 35$ & 4.00 & & & & 0.570 & 1.800 & & \\
\hline PGSP0025 & May/20/1992 & $14: 30$ & 5.60 & & & & 0.560 & 1.200 & & \\
\hline PGSP0026 & May/27/1992 & $10: 45$ & 1.40 & 1.200 & $<0.250$ & & $<0.070$ & 0.081 & 0.540 & 0.018 \\
\hline PGSP0027 & Jun/03/1992 & $15: 45$ & 1.50 & 0.940 & $<0.250$ & & 0.081 & $<0.060$ & 0.380 & $<0.018$ \\
\hline PGSP0028 & Jun/04/1992 & $2: 58$ & 1.40 & & & & 0.077 & $<0.060$ & & \\
\hline PGSP0029 & Jun/04/1992 & $3: 18$ & 1.20 & & & & 0.120 & $<0.060$ & & \\
\hline PGSP0030 & Jun/04/1992 & $3: 38$ & 1.20 & & & & 0.160 & $<0.060$ & & \\
\hline PGSP0031 & Jun/04/1992 & $3: 58$ & 1.20 & & & & 0.200 & $<0.060$ & & \\
\hline PGSP0032 & Jun/04/1992 & $4: 18$ & 1.40 & & & & 0.120 & $<0.060$ & & \\
\hline PGSP0033 & Jun/04/1992 & $4: 38$ & 2.20 & & & & 0.160 & 1.100 & & \\
\hline PGSP0034 & Jun/04/1992 & $4: 58$ & 2.80 & & & & 0.110 & 2.300 & & \\
\hline PGSP0035 & Jun/04/1992 & $5: 18$ & 2.30 & & & & $<0.070$ & 1.200 & & \\
\hline PGSP0036 & Jun/04/1992 & $5: 38$ & 2.10 & & & & $<0.070$ & 0.600 & & \\
\hline PGSP0037 & Jun/04/1992 & $5: 58$ & 2.60 & & & & $<0.070$ & 0.370 & & \\
\hline PGSP0038 & Jun/04/1992 & $6: 58$ & 3.70 & & & & 0.210 & 0.760 & & \\
\hline PGSP0039 & Jun/04/1992 & $7: 58$ & 2.20 & & & & 0.280 & 0.580 & & \\
\hline PGSP0040 & Jun/04/1992 & $8: 58$ & 2.90 & & & & 0.390 & 0.600 & & \\
\hline PGSP0041 & Jun/04/1992 & $9: 58$ & 2.20 & & & & 0.470 & 0.180 & & \\
\hline PGSP0042 & Jun/04/1992 & $10: 58$ & 1.90 & & & & 1.000 & 0.380 & & \\
\hline PGSP0043 & Jun/04/1992 & $11: 58$ & 2.00 & & & & 1.600 & 0.270 & & \\
\hline PGSP0044 & Jun/04/1992 & $12: 58$ & 2.90 & & & & 1.100 & 0.390 & & \\
\hline PGSP0045 & Jun/04/1992 & $13: 58$ & 2.70 & & & & 0.300 & 0.220 & & \\
\hline
\end{tabular}

*These statistics are presented as a descriptive summary of the table. The effects of aliasing and variable sampling intervals may significantly affect the validity of averages presented as representative of ground-water quality in the basin. No data means an analysis was not performed. 
Pleasant Grove Spring, October 1991-September 1992

\begin{tabular}{|c|c|c|c|c|c|c|c|c|c|c|}
\hline $\begin{array}{l}\text { Sample } \\
\text { Number }\end{array}$ & Date & Time (CST) & $\begin{array}{c}\text { Total ELISA } \\
\text { Triazines } \\
(\mu g / L)\end{array}$ & $\begin{array}{c}\text { Total GC } \\
\text { Atrazine } \\
(\mu g / L)\end{array}$ & $\begin{array}{c}\text { Total GC } \\
\text { Simazine } \\
(\mu \mathrm{g} / \mathrm{L})\end{array}$ & $\begin{array}{c}\text { Total GC } \\
\text { Cyanazine } \\
(\mu \mathrm{g} / \mathrm{L})\end{array}$ & $\begin{array}{c}\text { Total ELISA } \\
\text { Carbofuran } \\
(\mu g / L)\end{array}$ & $\begin{array}{c}\text { Total ELISA } \\
\text { Metolachlor } \\
(\mu g / L)\end{array}$ & $\begin{array}{c}\text { Total GC } \\
\text { Metolachlor } \\
(\mu g / L)\end{array}$ & $\begin{array}{c}\text { Total GC } \\
\text { Alachlor } \\
(\mu \mathrm{g} / \mathrm{L})\end{array}$ \\
\hline PGSP0046 & Jun/04/1992 & $14: 58$ & 2.30 & & & & 0.340 & 0.170 & & \\
\hline PGSP0047 & Jun/04/1992 & $15: 58$ & 2.50 & & & & 0.200 & 0.200 & & \\
\hline PGSP0052 & Jun/04/1992 & $17: 15$ & 3.00 & 2.600 & 0.300 & & 0.310 & 0.150 & 0.520 & 0.073 \\
\hline PGSP0048 & Jun/04/1992 & $19: 58$ & 3.40 & & & & 0.260 & 0.300 & & \\
\hline PGSP0049 & Jun/04/1992 & $23: 58$ & 4.00 & & & & 0.270 & 0.350 & & \\
\hline PGSP0050 & Jun/05/1992 & $3: 58$ & 4.20 & & & & 0.480 & 0.440 & & \\
\hline PGSP0051 & Jun/05/1992 & $7: 58$ & 3.00 & & & & 0.300 & 0.350 & & \\
\hline PGSP0053 & Jun/10/1992 & $13: 20$ & 1.10 & & & & 0.086 & $<0.060$ & & \\
\hline PGSP0054 & Jun/18/1992 & $9: 30$ & 1.10 & 1.000 & $<0.250$ & & 0.370 & $<0.060$ & 0.330 & 0.035 \\
\hline PGSP0055 & Jun/24/1992 & $13: 35$ & & & & & 0.120 & $<0.060$ & & \\
\hline PGSP0056 & Jul/01/1992 & $15: 00$ & 0.88 & & & & $<0.070$ & $<0.060$ & & \\
\hline PGSP0057 & Jul/08/1992 & $11: 15$ & 0.88 & & & & $<0.070$ & $<0.060$ & & \\
\hline PGSP0058 & Jul/13/1992 & $15: 00$ & 0.99 & & & & $<0.070$ & $<0.060$ & & \\
\hline PGSP0059 & Jul/23/1992 & $15: 45$ & 0.82 & & & & $<0.070$ & 0.081 & & \\
\hline PGSP0060 & Jul/30/1992 & $6: 55$ & 0.81 & & & & $<0.070$ & $<0.060$ & & \\
\hline PGSP0061 & Aug/13/1992 & $14: 15$ & 0.76 & & & & $<0.070$ & $<0.060$ & & \\
\hline PGSP0062 & Aug/26/1992 & $11: 30$ & 0.55 & 0.370 & $<0.083$ & $<0.100$ & $<0.070$ & $<0.060$ & $<0.040$ & $<0.018$ \\
\hline PGSP0063 & Sep/09/1992 & $11: 42$ & 0.57 & & & & $<0.070$ & $<0.060$ & & \\
\hline PGSP0064 & Sep/23/1992 & $14: 25$ & 0.61 & & & & $<0.070$ & 0.200 & & \\
\hline \multicolumn{3}{|r|}{ Average* $^{*}$} & 1.772 & 0.705 & 0.348 & & 0.232 & 0.321 & 0.193 & 0.028 \\
\hline \multicolumn{3}{|r|}{ Maximum } & 5.60 & 2.600 & 1.100 & & 1.600 & 2.300 & 0.540 & 0.073 \\
\hline \multicolumn{3}{|r|}{ Minimum } & 0.49 & 0.100 & $<0.083$ & & $<0.070$ & $<0.060$ & $<0.036$ & $<0.018$ \\
\hline \multicolumn{3}{|r|}{ Stand. Dev. } & 1.199 & 0.726 & 0.276 & & 0.292 & 0.469 & 0.201 & 0.019 \\
\hline \multicolumn{3}{|r|}{ Coef. Var. } & 0.677 & 1.030 & 0.795 & & 1.261 & 1.459 & 1.041 & 0.674 \\
\hline \multicolumn{3}{|r|}{ No. Analyses } & 51 & 11 & 11 & 1 & $\overline{52}$ & 49 & 12 & $\overline{12}$ \\
\hline
\end{tabular}

*These statistics are presented as a descriptive summary of the table. The effects of aliasing and variable sampling intervals may significantly affect the validity of averages presented as representative of ground-water quality in the basin. No data means an analysis was not performed. 
Spring Valley karst window, October 1991-September 1992

\begin{tabular}{|c|c|c|c|c|c|c|c|c|c|c|}
\hline $\begin{array}{l}\text { Sample } \\
\text { Number }\end{array}$ & Date & Time (CST) & $\begin{array}{c}\text { Total ELISA } \\
\text { Triazines } \\
(\mu g / L)\end{array}$ & $\begin{array}{c}\text { Total GC } \\
\text { Atrazine } \\
(\mu \mathrm{g} / \mathrm{L})\end{array}$ & $\begin{array}{c}\text { Total GC } \\
\text { Simazine } \\
(\mu \mathrm{g} / \mathrm{L})\end{array}$ & $\begin{array}{c}\text { Total GC } \\
\text { Cyanazine } \\
(\mu \mathrm{g} / \mathrm{L})\end{array}$ & $\begin{array}{c}\text { Total ELISA } \\
\text { Carbofuran } \\
(\mu g / L)\end{array}$ & $\begin{array}{c}\text { Total ELISA } \\
\text { Metolachlor } \\
(\mu g / L)\end{array}$ & $\begin{array}{c}\text { Total GC } \\
\text { Metolachlor } \\
(\mu \mathrm{g} / \mathrm{L})\end{array}$ & $\begin{array}{c}\text { Total GC } \\
\text { Alachlor } \\
(\mu g / L)\end{array}$ \\
\hline SVKW0008 & Oct/22/1991 & $8: 00$ & & 0.280 & $<0.250$ & & & & $<0.036$ & 0.021 \\
\hline SVKW0009 & Jan/29/1992 & $10: 00$ & & $<0.210$ & $<0.250$ & & & & $<0.040$ & $<0.018$ \\
\hline SVKW0010 & $\mathrm{Feb} / 26 / 1992$ & $11: 00$ & & 0.360 & 4.500 & & $<0.070$ & & $<0.040$ & $<0.018$ \\
\hline SVKW0011 & Mar/25/1992 & $10: 55$ & & 0.320 & $<0.250$ & & & & $<0.040$ & 0.041 \\
\hline SVKW0012 & Apr/01/1992 & $15: 15$ & 0.88 & & & & $<0.070$ & $<0.060$ & & \\
\hline SVKW0013 & Apr/29/1992 & $8: 40$ & 0.59 & 0.250 & $<0.250$ & & $<0.070$ & $<0.060$ & 0.110 & $<0.018$ \\
\hline SVKW0014 & May/27/1992 & $9: 15$ & 1.40 & 1.200 & $<0.250$ & & $<0.070$ & 0.070 & 0.400 & $<0.018$ \\
\hline & & Average* & 0.957 & 0.437 & 0.958 & & & & & \\
\hline & & Maximum & 1.40 & 1.200 & 4.500 & & $<0.070$ & 0.070 & 0.400 & 0.041 \\
\hline & & Minimum & 0.59 & $<0.210$ & $<0.250$ & & & $<0.060$ & $<0.036$ & $<0.018$ \\
\hline & & Stand. Dev. & 0.410 & 0.378 & 1.735 & & & & & \\
\hline & & Coef. Var. & 0.429 & 0.865 & 1.810 & & & & & \\
\hline & & No. Analyses & 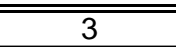 & $\overline{6}$ & 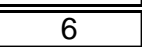 & & 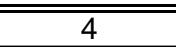 & $\overline{3}$ & 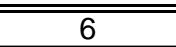 & $\overline{6}$ \\
\hline
\end{tabular}

The Canyon karst window, October 1991-September 1992

\begin{tabular}{|c|c|c|c|c|c|c|c|c|c|c|}
\hline $\begin{array}{l}\text { Sample } \\
\text { Number }\end{array}$ & Date & Time (CST) & $\begin{array}{c}\text { Total ELISA } \\
\text { Triazines } \\
(\mu g / L)\end{array}$ & $\begin{array}{c}\text { Total GC } \\
\text { Atrazine } \\
(\mu \mathrm{g} / \mathrm{L})\end{array}$ & $\begin{array}{c}\text { Total GC } \\
\text { Simazine } \\
(\mu g / L)\end{array}$ & $\begin{array}{c}\text { Total GC } \\
\text { Cyanazine } \\
(\mu \mathrm{g} / \mathrm{L})\end{array}$ & $\begin{array}{c}\text { Total ELISA } \\
\text { Carbofuran } \\
(\mu g / L)\end{array}$ & $\begin{array}{c}\text { Total ELISA } \\
\text { Metolachlor } \\
(\mu \mathrm{g} / \mathrm{L})\end{array}$ & $\begin{array}{c}\text { Total GC } \\
\text { Metolachlor } \\
(\mu \mathrm{g} / \mathrm{L})\end{array}$ & $\begin{array}{c}\text { Total GC } \\
\text { Alachlor } \\
(\mu \mathrm{g} / \mathrm{L})\end{array}$ \\
\hline TCKW0008 & $\mathrm{Dec} / 17 / 1991$ & $11: 30$ & & 0.300 & $<0.250$ & & & & $<0.040$ & $<0.018$ \\
\hline TCKW0009 & Jan/29/1992 & $8: 30$ & & 0.310 & $<0.250$ & & & & $<0.040$ & $<0.018$ \\
\hline TCKW0010 & Feb/26/1992 & $9: 45$ & & 0.280 & 2.200 & & $<0.070$ & & $<0.040$ & $<0.018$ \\
\hline TCKW0011 & Mar/25/1992 & $12: 00$ & & 0.440 & $<0.250$ & & & & $<0.040$ & $<0.018$ \\
\hline TCKW0012 & Apr/01/1992 & $14: 45$ & 0.96 & & & & $<0.070$ & & $<0.060$ & \\
\hline TCKW0013 & Apr/29/1992 & $7: 40$ & 0.65 & $<0.340$ & $<0.250$ & & $<0.070$ & & 0.220 & $<0.018$ \\
\hline TCKW0014 & May/27/1992 & $10: 05$ & 1.10 & 0.930 & $<0.250$ & & $<0.070$ & 0.110 & 0.410 & $<0.018$ \\
\hline \multicolumn{3}{|r|}{ Average ${ }^{*}$} & 0.903 & 0.433 & & & & & & \\
\hline \multicolumn{3}{|r|}{ Maximum } & 1.10 & 0.930 & 2.200 & & $<0.070$ & & 0.410 & $<0.018$ \\
\hline \multicolumn{3}{|r|}{ Minimum } & 0.65 & 0.280 & $<0.250$ & & & & $<0.040$ & \\
\hline \multicolumn{3}{|r|}{ Stand. Dev. } & 0.230 & 0.250 & & & & & & \\
\hline \multicolumn{3}{|r|}{ Coef. Var. } & 0.255 & 0.576 & & & & & & \\
\hline \multicolumn{3}{|r|}{ No. Analyses } & 3 & 6 & 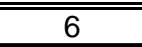 & & 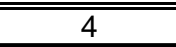 & 1 & $\overline{7}$ & 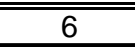 \\
\hline
\end{tabular}

${ }^{*}$ These statistics are presented as a descriptive summary of the table. The effects of aliasing and variable sampling intervals may significantly affect the validity of averages presented as representative of ground-water quality in the basin. No data means an analysis was not performed. 
Shackelford Spring, October 1991-September 1992

\begin{tabular}{|c|c|c|c|c|c|c|c|c|c|c|}
\hline $\begin{array}{l}\text { Sample } \\
\text { Number }\end{array}$ & Date & Time (CST) & $\begin{array}{c}\text { Total ELISA } \\
\text { Triazines } \\
(\mu g / L)\end{array}$ & $\begin{array}{c}\text { Total GC } \\
\text { Atrazine } \\
(\mu g / L)\end{array}$ & $\begin{array}{c}\text { Total GC } \\
\text { Simazine } \\
(\mu \mathrm{g} / \mathrm{L})\end{array}$ & $\begin{array}{c}\text { Total GC } \\
\text { Cyanazine } \\
(\mu \mathrm{g} / \mathrm{L})\end{array}$ & $\begin{array}{c}\text { Total ELISA } \\
\text { Carbofuran } \\
(\mu g / L)\end{array}$ & $\begin{array}{c}\text { Total ELISA } \\
\text { Metolachlor } \\
(\mu g / L)\end{array}$ & $\begin{array}{c}\text { Total GC } \\
\text { Metolachlor } \\
(\mu \mathrm{g} / \mathrm{L})\end{array}$ & $\begin{array}{c}\text { Total GC } \\
\text { Alachlor } \\
(\mu \mathrm{g} / \mathrm{L})\end{array}$ \\
\hline SKSP0008 & Oct/22/1991 & $6: 34$ & & 0.290 & $<0.250$ & & & & $<0.036$ & $<0.020$ \\
\hline SKSP0009 & Dec/17/1991 & $12: 00$ & & 0.480 & $<0.250$ & & & & $<0.040$ & $<0.018$ \\
\hline SKSP0010 & Jan/28/1992 & $14: 30$ & & 0.300 & $<0.250$ & & & & $<0.040$ & $<0.018$ \\
\hline SKSP0011 & Feb/26/1992 & $8: 40$ & & 0.310 & $<0.250$ & & $<0.070$ & & $<0.040$ & $<0.018$ \\
\hline SKSP0012 & Mar/25/1992 & $15: 15$ & & $<0.210$ & $<0.250$ & & & & $<0.040$ & $<0.018$ \\
\hline SKSP0013 & Apr/29/1992 & $6: 43$ & 0.51 & 0.250 & $<0.250$ & & $<0.070$ & & $<0.040$ & $<0.018$ \\
\hline SKSP0014 & May/27/1992 & $11: 50$ & 1.10 & 0.830 & $<0.250$ & & $<0.070$ & $<0.060$ & 0.120 & $<0.018$ \\
\hline & & Average* $^{\star}$ & 0.805 & 0.381 & & & & & & \\
\hline & & Maximum & 1.10 & 0.830 & $<0.250$ & & $<0.070$ & & 0.120 & $<0.020$ \\
\hline & & Minimum & 0.51 & 0.210 & & & & & $<0.036$ & \\
\hline & & Stand. Dev. & & 0.215 & & & & & & \\
\hline & & Coef. Var. & & 0.564 & & & & & & \\
\hline & & No. Analyses & 2 & 7 & 7 & & 3 & 1 & 7 & 7 \\
\hline
\end{tabular}

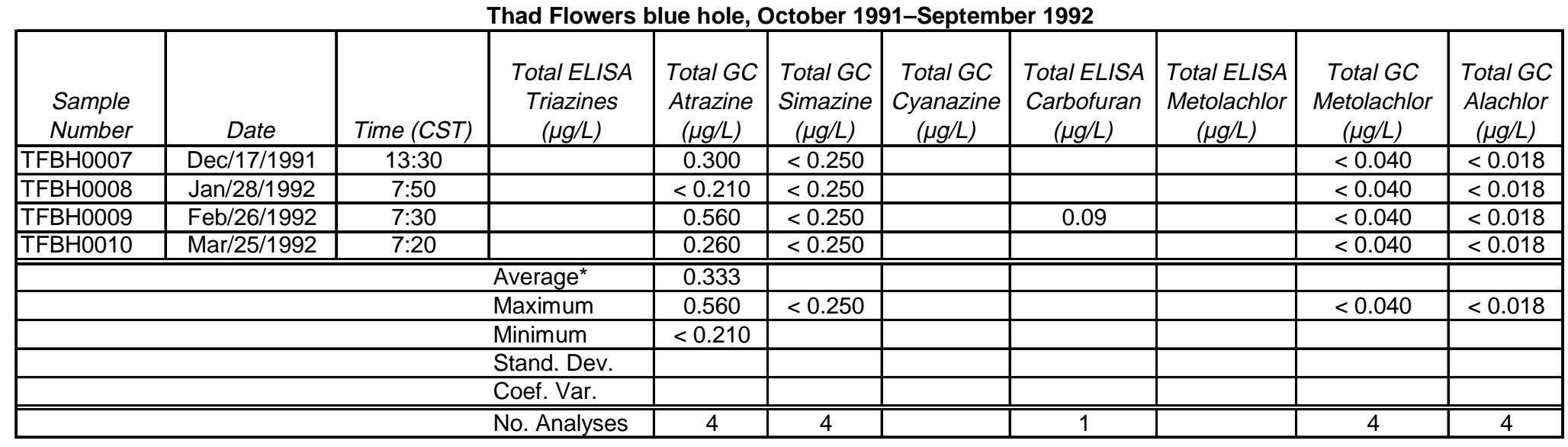

*These statistics are presented as a descriptive summary of the table. The effects of aliasing and variable sampling intervals may significantly affect the validity of averages presented as representative of ground-water quality in the basin. No data means an analysis was not performed. 
George Delaney swallow hole, October 1991-September 1992

\begin{tabular}{|c|c|c|c|c|c|c|c|c|c|c|}
\hline $\begin{array}{l}\text { Sample } \\
\text { Number }\end{array}$ & Date & Time (CST) & $\begin{array}{c}\text { Total ELISA } \\
\text { Triazines } \\
(\mu g / L)\end{array}$ & $\begin{array}{c}\text { Total GC } \\
\text { Atrazine } \\
(\mu g / L)\end{array}$ & $\begin{array}{c}\text { Total GC } \\
\text { Simazine } \\
(\mu g / L)\end{array}$ & $\begin{array}{c}\text { Total GC } \\
\text { Cyanazine } \\
(\mu \mathrm{g} / \mathrm{L})\end{array}$ & $\begin{array}{c}\text { Total ELISA } \\
\text { Carbofuran } \\
(\mu \mathrm{g} / \mathrm{L})\end{array}$ & $\begin{array}{c}\text { Total ELISA } \\
\text { Metolachlor } \\
(\mu \mathrm{g} / \mathrm{L})\end{array}$ & $\begin{array}{c}\text { Total GC } \\
\text { Metolachlor } \\
(\mu g / L)\end{array}$ & $\begin{array}{c}\text { Total GC } \\
\text { Alachlor } \\
(\mu g / L)\end{array}$ \\
\hline GDSW0004 & Dec/17/1991 & $10: 00$ & & 0.230 & $<0.250$ & & & & $<0.040$ & 0.071 \\
\hline GDSW0005 & Jan/29/1992 & $9: 10$ & & $<0.210$ & 0.420 & & & & $<0.040$ & $<0.018$ \\
\hline GDSW0006 & Feb/26/1992 & $10: 20$ & & 0.460 & 1.000 & & $<0.070$ & & $<0.040$ & $<0.018$ \\
\hline GDSW0007 & Mar/25/1992 & $9: 45$ & & $<0.210$ & $<0.250$ & & & & $<0.040$ & 0.043 \\
\hline GDSW0008 & Apr/01/1992 & $15: 45$ & 0.48 & & & & $<0.070$ & $<0.060$ & & \\
\hline \multicolumn{11}{|c|}{ Average $^{*}$} \\
\hline & & Maximum & & 0.460 & 1.000 & & $<0.070$ & & $<0.040$ & 0.071 \\
\hline & & Minimum & & $<0.210$ & $<0.250$ & & & & & $<0.018$ \\
\hline & & No. Analyses & 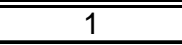 & 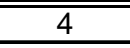 & 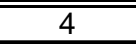 & & 2 & 1 & 4 & 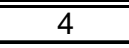 \\
\hline
\end{tabular}

*These statistics are presented as a descriptive summary of the table. The effects of aliasing and variable sampling intervals may significantly affect the validity of averages presented as representative of ground-water quality in the basin. No data means an analysis was not performed. 
Pleasant Grove Spring, October 1992-September 1993

\begin{tabular}{|c|c|c|c|c|c|c|c|c|c|c|}
\hline $\begin{array}{l}\text { Sample } \\
\text { Number }\end{array}$ & Date & Time (CST) & $\begin{array}{c}\text { Total ELISA } \\
\text { Triazines } \\
(\mu g / L)\end{array}$ & $\begin{array}{c}\text { Total GC } \\
\text { Atrazine } \\
(\mu g / L)\end{array}$ & $\begin{array}{c}\text { Total GC } \\
\text { Simazine } \\
(\mu \mathrm{g} / \mathrm{L})\end{array}$ & $\begin{array}{c}\text { Total GC } \\
\text { Cyanazine } \\
(\mu \mathrm{g} / \mathrm{L})\end{array}$ & $\begin{array}{c}\text { Total ELISA } \\
\text { Carbofuran } \\
(\mu g / L)\end{array}$ & $\begin{array}{c}\text { Total ELISA } \\
\text { Metolachlor } \\
(\mu g / L)\end{array}$ & $\begin{array}{c}\text { Total GC } \\
\text { Metolachlor } \\
(\mu \mathrm{g} / \mathrm{L})\end{array}$ & $\begin{array}{c}\text { Total GC } \\
\text { Alachlor } \\
(\mu g / L)\end{array}$ \\
\hline PGSP0065 & Oct/06/1992 & $12: 50$ & 0.76 & & $<0.160$ & $<0.150$ & $<0.070$ & $<0.060$ & $<0.035$ & $<0.018$ \\
\hline PGSP0066 & Oct/22/1992 & $10: 14$ & 0.41 & & & & $<0.070$ & $<0.060$ & & \\
\hline PGSP0067 & Nov/06/1992 & 9:00 & 0.53 & 0.270 & $<0.160$ & $<0.150$ & $<0.070$ & $<0.060$ & $<0.035$ & $<0.018$ \\
\hline PGSP0068 & Nov/20/1992 & $11: 54$ & 0.62 & & & & $<0.070$ & $<0.060$ & & \\
\hline PGSP0070 & Dec/03/1992 & 9:07 & 0.76 & 0.330 & $<0.160$ & $<0.150$ & $<0.070$ & $<0.060$ & $<0.035$ & $<0.018$ \\
\hline PGSP0071 & Jan/08/1993 & $10: 19$ & 0.74 & 0.340 & $<0.160$ & $<0.200$ & $<0.070$ & $<0.060$ & $<0.035$ & $<0.018$ \\
\hline PGSP0072 & Jan/13/1993 & $8: 00$ & 0.59 & & & & $<0.070$ & $<0.060$ & & \\
\hline PGSP0073 & Jan/13/1993 & 9:00 & 0.57 & & & & $<0.070$ & $<0.060$ & & \\
\hline PGSP0074 & Jan/13/1993 & $10: 00$ & 0.62 & & & & $<0.070$ & $<0.060$ & & \\
\hline PGSP0075 & $\operatorname{Jan} / 13 / 1993$ & $11: 00$ & 0.66 & & & & $<0.070$ & $<0.060$ & & \\
\hline PGSP0076 & Jan/13/1993 & $12: 00$ & 0.62 & & & & $<0.070$ & $<0.060$ & & \\
\hline PGSP0077 & Jan/13/1993 & $13: 00$ & 0.64 & & & & $<0.070$ & 0.730 & & \\
\hline PGSP0078 & Jan/13/1993 & $14: 00$ & 0.62 & & & & $<0.070$ & $<0.060$ & & $<0.060$ \\
\hline PGSP0079 & Jan/13/1993 & $15: 00$ & 0.59 & & & & $<0.070$ & 0.066 & & \\
\hline PGSP0080 & Jan/13/1993 & $16: 00$ & 0.54 & & & & $<0.070$ & $<0.060$ & & \\
\hline PGSP0081 & Jan/13/1993 & $17: 00$ & 0.63 & & & & $<0.070$ & $<0.060$ & & \\
\hline PGSP0082 & Jan/21/1993 & $10: 15$ & 0.52 & & & & $<0.070$ & $<0.060$ & & \\
\hline PGSP0083 & Jan/28/1993 & $15: 06$ & 0.58 & & & & $<0.070$ & $<0.060$ & & \\
\hline PGSP0084 & $\operatorname{Jan} / 28 / 1993$ & $15: 40$ & 0.62 & & & & $<0.070$ & $<0.060$ & & \\
\hline PGSP0089 & Jan/28/1993 & $20: 40$ & 0.60 & & & & $<0.070$ & $<0.060$ & & \\
\hline PGSP0095 & Jan/29/1993 & $2: 40$ & 0.64 & & & & $<0.070$ & $<0.060$ & & \\
\hline PGSP0101 & Jan/29/1993 & $8: 40$ & 0.60 & & & & $<0.070$ & $<0.060$ & & \\
\hline PGSP0107 & Jan/29/1993 & $14: 40$ & 0.67 & & & & $<0.070$ & $<0.060$ & & \\
\hline PGSP0108 & Feb/04/1993 & $10: 00$ & $<0.06$ & 0.290 & $<0.160$ & $<0.200$ & $<0.070$ & $<0.060$ & $<0.035$ & $<0.018$ \\
\hline PGSP0109 & Feb/16/1993 & $6: 10$ & 0.64 & & & & $<0.070$ & $<0.060$ & & \\
\hline PGSP0110 & Feb/16/1993 & $6: 30$ & 0.63 & & & & $<0.070$ & $<0.060$ & & \\
\hline PGSP0111 & Feb/16/1993 & $6: 50$ & 0.70 & & & & $<0.070$ & $<0.060$ & & \\
\hline PGSP0112 & Feb/16/1993 & $7: 10$ & 0.65 & & & & $<0.070$ & $<0.060$ & & \\
\hline PGSP0113 & Feb/16/1993 & $7: 30$ & 0.74 & & & & $<0.070$ & $<0.060$ & & \\
\hline PGSP0114 & Feb/16/1993 & $7: 50$ & 0.64 & & & & $<0.070$ & $<0.060$ & & \\
\hline PGSP0115 & Feb/16/1993 & $8: 10$ & 0.73 & & & & $<0.070$ & $<0.060$ & & \\
\hline PGSP0116 & Feb/16/1993 & $8: 30$ & 0.79 & & & & $<0.070$ & $<0.060$ & & \\
\hline PGSP0117 & Feb/16/1993 & $8: 50$ & 0.67 & & & & $<0.070$ & $<0.060$ & & \\
\hline PGSP0118 & Feb/16/1993 & $9: 10$ & 0.67 & & & & $<0.070$ & $<0.060$ & & \\
\hline PGSP0119 & $\mathrm{Feb} / 16 / 1993$ & $10: 10$ & 0.67 & & & & $<0.070$ & $<0.060$ & & \\
\hline
\end{tabular}

*These statistics are presented as a descriptive summary of the table. The effects of aliasing and variable sampling intervals may significantly affect the validity of averages presented as representative of ground-water quality in the basin. No data means an analysis was not performed. 
Pleasant Grove Spring, October 1992-September 1993

\begin{tabular}{|c|c|c|c|c|c|c|c|c|c|c|}
\hline $\begin{array}{l}\text { Sample } \\
\text { Number }\end{array}$ & Date & Time (CST) & $\begin{array}{c}\text { Total ELISA } \\
\text { Triazines } \\
(\mu g / L)\end{array}$ & $\begin{array}{c}\text { Total GC } \\
\text { Atrazine } \\
(\mu g / L)\end{array}$ & $\begin{array}{c}\text { Total GC } \\
\text { Simazine } \\
(\mu \mathrm{g} / \mathrm{L})\end{array}$ & $\begin{array}{c}\text { Total GC } \\
\text { Cyanazine } \\
(\mu \mathrm{g} / \mathrm{L})\end{array}$ & $\begin{array}{c}\text { Total ELISA } \\
\text { Carbofuran } \\
(\mu g / L)\end{array}$ & $\begin{array}{c}\text { Total ELISA } \\
\text { Metolachlor } \\
(\mu g / L)\end{array}$ & $\begin{array}{c}\text { Total GC } \\
\text { Metolachlor } \\
(\mu \mathrm{g} / \mathrm{L})\end{array}$ & $\begin{array}{c}\text { Total GC } \\
\text { Alachlor } \\
(\mu \mathrm{g} / \mathrm{L})\end{array}$ \\
\hline PGSP0120 & Feb/16/1993 & $11: 10$ & 0.72 & & & & $<0.070$ & $<0.060$ & & \\
\hline PGSP0121 & Feb/16/1993 & $12: 10$ & 0.72 & & & & $<0.070$ & $<0.060$ & & \\
\hline PGSP0122 & Feb/16/1993 & $13: 10$ & 0.72 & & & & $<0.070$ & $<0.060$ & & \\
\hline PGSP0123 & Feb/16/1993 & $14: 10$ & 0.74 & & & & $<0.070$ & 0.074 & & \\
\hline PGSP0124 & Feb/16/1993 & $15: 10$ & 0.72 & & & & $<0.070$ & 0.065 & & \\
\hline PGSP0125 & Feb/16/1993 & $16: 10$ & 0.76 & 0.290 & $<0.160$ & $<0.200$ & $<0.070$ & 0.066 & $<0.035$ & \\
\hline PGSP0126 & Feb/16/1993 & $17: 10$ & 0.75 & & & & $<0.070$ & 0.083 & & \\
\hline PGSP0127 & Feb/16/1993 & $18: 10$ & 0.69 & & & & $<0.070$ & 0.060 & & \\
\hline PGSP0128 & Feb/16/1993 & 19:10 & 0.72 & & & & $<0.070$ & 0.060 & & \\
\hline PGSP0129 & Feb/16/1993 & $23: 10$ & 0.68 & & & & $<0.070$ & 0.062 & & \\
\hline PGSP0130 & Feb/17/1993 & $3: 10$ & 0.66 & & & & $<0.070$ & $<0.060$ & & \\
\hline PGSP0131 & Feb/17/1993 & $7: 10$ & 0.70 & & & & $<0.070$ & 0.066 & & \\
\hline PGSP0132 & Feb/17/1993 & $11: 10$ & 0.71 & & & & $<0.070$ & $<0.060$ & & \\
\hline PGSP0133 & Feb/17/1993 & $16: 30$ & 0.79 & & & & $<0.070$ & 0.061 & & \\
\hline PGSP0134 & Feb/18/1993 & $8: 00$ & 0.83 & & & & $<0.070$ & $<0.060$ & & \\
\hline PGSP0135 & Feb/21/1993 & $10: 13$ & 0.54 & & & & $<0.070$ & $<0.060$ & & \\
\hline PGSP0136 & Feb/21/1993 & $10: 33$ & 0.58 & & & & $<0.070$ & $<0.060$ & & \\
\hline PGSP0137 & Feb/21/1993 & $10: 53$ & 0.60 & & & & $<0.070$ & $<0.060$ & & \\
\hline PGSP0138 & Feb/21/1993 & $11: 13$ & 0.54 & & & & $<0.070$ & $<0.060$ & & \\
\hline PGSP0139 & Feb/21/1993 & $11: 33$ & 0.58 & & & & $<0.070$ & $<0.060$ & & \\
\hline PGSP0140 & Feb/21/1993 & $11: 53$ & 0.59 & & & & $<0.070$ & $<0.060$ & & \\
\hline PGSP0141 & Feb/21/1993 & $12: 13$ & 0.53 & & & & $<0.070$ & $<0.060$ & & \\
\hline PGSP0142 & Feb/21/1993 & $12: 33$ & 0.60 & & & & $<0.070$ & $<0.060$ & & \\
\hline PGSP0143 & Feb/21/1993 & $12: 53$ & 0.60 & & & & $<0.070$ & $<0.060$ & & \\
\hline PGSP0144 & Feb/21/1993 & $13: 13$ & 0.59 & & & & $<0.070$ & $<0.060$ & & \\
\hline PGSP0145 & Feb/21/1993 & $14: 13$ & 0.57 & & & & $<0.070$ & $<0.060$ & & \\
\hline PGSP0146 & Feb/21/1993 & $15: 13$ & 0.58 & & & & $<0.070$ & $<0.060$ & & \\
\hline PGSP0147 & Feb/21/1993 & $16: 13$ & 0.55 & & & & $<0.070$ & $<0.060$ & & \\
\hline PGSP0148 & Feb/21/1993 & $17: 13$ & 0.55 & & & & $<0.070$ & $<0.060$ & & \\
\hline PGSP0149 & Feb/21/1993 & $18: 13$ & 0.58 & & & & $<0.070$ & $<0.060$ & & \\
\hline PGSP0150 & Feb/21/1993 & $19: 13$ & 0.49 & & & & $<0.070$ & $<0.060$ & & \\
\hline PGSP0151 & Feb/21/1993 & $20: 13$ & 0.52 & & & & $<0.070$ & $<0.060$ & & \\
\hline PGSP0152 & Feb/21/1993 & $21: 13$ & 0.51 & & & & $<0.070$ & $<0.060$ & & \\
\hline PGSP0153 & Feb/21/1993 & $22: 13$ & 0.53 & & & & $<0.070$ & $<0.060$ & & \\
\hline
\end{tabular}

*These statistics are presented as a descriptive summary of the table. The effects of aliasing and variable sampling intervals may significantly affect the validity of averages presented as representative of ground-water quality in the basin. No data means an analysis was not performed. 
Pleasant Grove Spring, October 1992-September 1993

\begin{tabular}{|c|c|c|c|c|c|c|c|c|c|c|}
\hline $\begin{array}{l}\text { Sample } \\
\text { Number }\end{array}$ & Date & Time (CST) & $\begin{array}{c}\text { Total ELISA } \\
\text { Triazines } \\
(\mu g / L)\end{array}$ & $\begin{array}{c}\text { Total GC } \\
\text { Atrazine } \\
(\mu \mathrm{g} / \mathrm{L})\end{array}$ & $\begin{array}{c}\text { Total GC } \\
\text { Simazine } \\
(\mu \mathrm{g} / \mathrm{L})\end{array}$ & $\begin{array}{c}\text { Total GC } \\
\begin{array}{c}\text { Cyanazine } \\
(\mu g / L)\end{array}\end{array}$ & $\begin{array}{c}\text { Total ELISA } \\
\text { Carbofuran } \\
(\mu g / L)\end{array}$ & $\begin{array}{c}\text { Total ELISA } \\
\text { Metolachlor } \\
(\mu \mathrm{g} / \mathrm{L})\end{array}$ & $\begin{array}{c}\text { Total GC } \\
\text { Metolachlor } \\
(\mu \mathrm{g} / \mathrm{L})\end{array}$ & $\begin{array}{c}\text { Total GC } \\
\text { Alachlor } \\
(\mu \mathrm{g} / \mathrm{L})\end{array}$ \\
\hline PGSP0154 & Feb/21/1993 & $23: 13$ & 0.69 & & & & $<0.070$ & $<0.060$ & & \\
\hline PGSP0155 & Feb/22/1993 & $3: 13$ & 0.55 & & & & $<0.070$ & $<0.060$ & & \\
\hline PGSP0156 & Feb/22/1993 & $7: 13$ & 0.51 & & & & $<0.070$ & $<0.060$ & & \\
\hline PGSP0157 & Feb/22/1993 & $11: 13$ & 0.56 & & & & $<0.070$ & $<0.060$ & & \\
\hline PGSP0158 & Feb/22/1993 & $15: 13$ & 0.60 & & & & $<0.070$ & $<0.060$ & & \\
\hline PGSP0159 & Mar/03/1993 & $9: 00$ & 0.55 & 0.260 & $<0.360$ & $<0.240$ & $<0.070$ & $<0.060$ & $<0.031$ & $<0.018$ \\
\hline PGSP0160 & Mar/18/1993 & $10: 20$ & 0.51 & & & & $<0.070$ & $<0.060$ & & \\
\hline PGSP0161 & Mar/22/1993 & $20: 15$ & 0.59 & & & & $<0.070$ & $<0.060$ & & \\
\hline PGSP0172 & Mar/23/1993 & $1: 15$ & 0.58 & & & & $<0.070$ & $<0.060$ & & \\
\hline PGSP0176 & Mar/23/1993 & $5: 15$ & 0.60 & & & & $<0.070$ & 0.069 & & \\
\hline PGSP0180 & Mar/23/1993 & $9: 15$ & 0.63 & & & & $<0.070$ & $<0.060$ & & \\
\hline PGSP0181 & Mar/23/1993 & $13: 15$ & 0.56 & & & & $<0.070$ & 0.075 & & \\
\hline PGSP0182 & Mar/23/1993 & $17: 15$ & 0.44 & & & & $<0.070$ & $<0.060$ & & \\
\hline PGSP0183 & Mar/23/1993 & $21: 15$ & 1.80 & & & & $<0.070$ & 0.067 & & \\
\hline PGSP0184 & Mar/24/1993 & $1: 15$ & 2.60 & & & & $<0.070$ & $<0.060$ & & \\
\hline PGSP0185 & Mar/25/1993 & $11: 00$ & 1.20 & & & & $<0.070$ & $<0.060$ & & \\
\hline PGSP0186 & Mar/26/1993 & $2: 28$ & 0.98 & & & & $<0.070$ & $<0.060$ & & \\
\hline PGSP0187 & Mar/26/1993 & $2: 48$ & 0.94 & & & & $<0.070$ & $<0.060$ & & \\
\hline PGSP0188 & Mar/26/1993 & $3: 08$ & 0.90 & & & & $<0.070$ & $<0.060$ & & \\
\hline PGSP0189 & Mar/26/1993 & $3: 28$ & 1.00 & & & & $<0.070$ & $<0.060$ & & \\
\hline PGSP0190 & Mar/26/1993 & $3: 48$ & 0.88 & & & & $<0.070$ & $<0.060$ & & \\
\hline PGSP0191 & Mar/26/1993 & $4: 08$ & 1.00 & & & & $<0.070$ & $<0.060$ & & \\
\hline PGSP0192 & Mar/26/1993 & $4: 28$ & 0.81 & & & & $<0.070$ & $<0.060$ & & \\
\hline PGSP0193 & Mar/26/1993 & $4: 48$ & 0.97 & & & & $<0.070$ & $<0.060$ & & \\
\hline PGSP0194 & Mar/26/1993 & $5: 08$ & 0.85 & & & & $<0.070$ & $<0.060$ & & \\
\hline PGSP0195 & Mar/26/1993 & $5: 28$ & 1.00 & & & & $<0.070$ & $<0.060$ & & \\
\hline PGSP0196 & Mar/26/1993 & $6: 28$ & 0.86 & & & & $<0.070$ & $<0.060$ & & \\
\hline PGSP0197 & Mar/26/1993 & $7: 28$ & 0.82 & & & & $<0.070$ & $<0.060$ & & \\
\hline PGSP0198 & Mar/26/1993 & $8: 28$ & 0.90 & & & & $<0.070$ & $<0.060$ & & \\
\hline PGSP0199 & Mar/26/1993 & $9: 28$ & 0.82 & & & & $<0.070$ & $<0.060$ & & \\
\hline PGSP0200 & Mar/26/1993 & $10: 28$ & 0.77 & & & & $<0.070$ & $<0.060$ & & \\
\hline PGSP0201 & Mar/26/1993 & $11: 28$ & 0.76 & & & & $<0.070$ & $<0.060$ & & \\
\hline PGSP0202 & Mar/26/1993 & $12: 28$ & 0.79 & & & & $<0.070$ & $<0.060$ & & \\
\hline PGSP0203 & Mar/26/1993 & $13: 28$ & 0.84 & & & & $<0.070$ & $<0.060$ & & \\
\hline
\end{tabular}

*These statistics are presented as a descriptive summary of the table. The effects of aliasing and variable sampling intervals may significantly affect the validity of averages presented as representative of ground-water quality in the basin. No data means an analysis was not performed. 
Pleasant Grove Spring, October 1992-September 1993

\begin{tabular}{|c|c|c|c|c|c|c|c|c|c|c|}
\hline $\begin{array}{l}\text { Sample } \\
\text { Number }\end{array}$ & Date & Time (CST) & $\begin{array}{c}\text { Total ELISA } \\
\text { Triazines } \\
(\mu g / L)\end{array}$ & $\begin{array}{c}\text { Total GC } \\
\text { Atrazine } \\
(\mu \mathrm{g} / \mathrm{L})\end{array}$ & $\begin{array}{c}\text { Total GC } \\
\text { Simazine } \\
(\mu \mathrm{g} / \mathrm{L})\end{array}$ & $\begin{array}{c}\text { Total GC } \\
\text { Cyanazine } \\
(\mu \mathrm{g} / \mathrm{L})\end{array}$ & $\begin{array}{c}\text { Total ELISA } \\
\text { Carbofuran } \\
(\mu g / L)\end{array}$ & $\begin{array}{c}\text { Total ELISA } \\
\text { Metolachlor } \\
(\mu g / L)\end{array}$ & $\begin{array}{c}\text { Total GC } \\
\text { Metolachlor } \\
(\mu \mathrm{g} / \mathrm{L})\end{array}$ & $\begin{array}{c}\text { Total GC } \\
\text { Alachlor } \\
(\mu \mathrm{g} / \mathrm{L})\end{array}$ \\
\hline PGSP0204 & Mar/26/1993 & $14: 28$ & 0.81 & & & & $<0.070$ & $<0.060$ & & \\
\hline PGSP0205 & Mar/26/1993 & $15: 28$ & 0.87 & & & & $<0.070$ & $<0.060$ & & \\
\hline PGSP0206 & Mar/26/1993 & $19: 28$ & 1.10 & & & & $<0.070$ & $<0.060$ & & \\
\hline PGSP0207 & Mar/26/1993 & $23: 28$ & 1.20 & & & & $<0.070$ & $<0.060$ & & \\
\hline PGSP0208 & Mar/27/1993 & $3: 28$ & 1.20 & & & & $<0.070$ & $<0.060$ & & \\
\hline PGSP0209 & Mar/27/1993 & $7: 28$ & 1.10 & & & & $<0.070$ & $<0.060$ & & \\
\hline PGSP0210 & Apr/01/1993 & $16: 54$ & 0.90 & & & & $<0.070$ & $<0.060$ & & \\
\hline PGSP0211 & Apr/07/1993 & $8: 22$ & 0.53 & 0.430 & $<0.360$ & $<0.240$ & $<0.070$ & $<0.060$ & $<0.031$ & $<0.018$ \\
\hline PGSP0212 & Apr/21/1993 & $15: 10$ & 1.10 & & & & $<0.070$ & $<0.060$ & & \\
\hline PGSP0213 & May/03/1993 & $17: 39$ & 1.20 & & & & $<0.070$ & $<0.060$ & & \\
\hline PGSP0214 & May/03/1993 & $18: 39$ & 30.0 & & & & $<0.070$ & 9.300 & & \\
\hline PGSP0215 & May/04/1993 & $13: 50$ & 41.0 & 28.000 & $<0.260$ & 4.400 & 0.740 & 8.200 & 5.100 & 6.100 \\
\hline PGSP0216 & May/04/1993 & $14: 50$ & 44.0 & & & & 0.830 & 9.600 & & \\
\hline PGSP0217 & May/04/1993 & $15: 50$ & 42.0 & & & & 0.870 & 9.300 & & \\
\hline PGSP0218 & May/04/1993 & $16: 50$ & 39.0 & & & & 0.950 & 8.100 & & \\
\hline PGSP0219 & May/04/1993 & $17: 50$ & 42.0 & & & & 0.900 & 7.800 & & \\
\hline PGSP0220 & May/04/1993 & $18: 50$ & 39.0 & & & & 0.890 & 7.900 & & \\
\hline PGSP0221 & May/04/1993 & $19: 50$ & 38.0 & & & & 0.760 & 7.400 & & \\
\hline PGSP0222 & May/04/1993 & $20: 50$ & 38.0 & & & & 0.700 & 7.800 & & \\
\hline PGSP0223 & May/04/1993 & $21: 50$ & 40.0 & & & & 0.790 & 7.100 & & \\
\hline PGSP0224 & May/04/1993 & $22: 50$ & 43.0 & & & & 0.710 & 6.900 & & \\
\hline PGSP0225 & May/05/1993 & $1: 50$ & 40.0 & & & & 0.640 & 7.200 & & \\
\hline PGSP0226 & May/05/1993 & $4: 50$ & 29.0 & & & & 0.500 & 7.100 & & \\
\hline PGSP0227 & May/05/1993 & $7: 50$ & 31.0 & & & & 0.500 & 7.000 & & \\
\hline PGSP0228 & May/05/1993 & $10: 50$ & 30.0 & & & & 0.430 & 5.900 & & \\
\hline PGSP0229 & May/05/1993 & $13: 50$ & 28.0 & & & & 0.400 & 5.000 & & \\
\hline PGSP0230 & May/05/1993 & $16: 50$ & 28.0 & & & & 0.350 & 4.600 & & \\
\hline PGSP0231 & May/05/1993 & $19: 50$ & 27.0 & & & & 0.340 & 4.500 & & \\
\hline PGSP0232 & May/05/1993 & $22: 50$ & 24.0 & & & & 0.300 & 4.300 & & \\
\hline PGSP0233 & May/06/1993 & $1: 50$ & 24.0 & & & & 0.300 & 3.300 & & \\
\hline PGSP0234 & May/06/1993 & $9: 15$ & 23.0 & & & & 0.240 & 2.600 & & \\
\hline PGSP0235 & May/18/1993 & $3: 22$ & 3.30 & & & & $<0.070$ & 0.910 & & \\
\hline PGSP0241 & May/18/1993 & $9: 22$ & 3.00 & & & & $<0.070$ & 0.690 & & \\
\hline PGSP0251 & May/19/1993 & $9: 22$ & 2.80 & & & & $<0.070$ & 0.730 & & \\
\hline
\end{tabular}

*These statistics are presented as a descriptive summary of the table. The effects of aliasing and variable sampling intervals may significantly affect the validity of averages presented as representative of ground-water quality in the basin. No data means an analysis was not performed. 
Pleasant Grove Spring, October 1992-September 1993

\begin{tabular}{|c|c|c|c|c|c|c|c|c|c|c|}
\hline $\begin{array}{l}\text { Sample } \\
\text { Number }\end{array}$ & Date & Time (CST) & $\begin{array}{c}\text { Total ELISA } \\
\text { Triazines } \\
(\mu g / L)\end{array}$ & $\begin{array}{c}\text { Total GC } \\
\text { Atrazine } \\
(\mu \mathrm{g} / \mathrm{L})\end{array}$ & $\begin{array}{c}\text { Total GC } \\
\text { Simazine } \\
(\mu \mathrm{g} / \mathrm{L})\end{array}$ & $\begin{array}{c}\text { Total GC } \\
\begin{array}{c}\text { Cyanazine } \\
(\mu g / L)\end{array}\end{array}$ & $\begin{array}{c}\text { Total ELISA } \\
\text { Carbofuran } \\
(\mu g / L)\end{array}$ & $\begin{array}{c}\text { Total ELISA } \\
\text { Metolachlor } \\
(\mu \mathrm{g} / \mathrm{L})\end{array}$ & $\begin{array}{c}\text { Total GC } \\
\text { Metolachlor } \\
(\mu \mathrm{g} / \mathrm{L})\end{array}$ & $\begin{array}{c}\text { Total GC } \\
\text { Alachlor } \\
(\mu \mathrm{g} / \mathrm{L})\end{array}$ \\
\hline PGSP0255 & May/20/1993 & $9: 42$ & 2.80 & & & & $<0.070$ & 0.770 & & \\
\hline PGSP0256 & May/21/1993 & $2: 15$ & 2.40 & & & & $<0.070$ & 0.320 & & \\
\hline PGSP0257 & May/22/1993 & $2: 15$ & 2.30 & & & & $<0.070$ & 0.280 & & \\
\hline PGSP0258 & May/23/1993 & $2: 15$ & 2.40 & & & & $<0.070$ & 0.250 & & \\
\hline PGSP0259 & May/24/1993 & $2: 15$ & 1.90 & & & & $<0.070$ & 0.260 & & \\
\hline PGSP0260 & May/26/1993 & $12: 42$ & 2.10 & & & & $<0.070$ & 0.200 & & \\
\hline PGSP0261 & May/29/1993 & $18: 50$ & 2.00 & & & & $<0.070$ & 0.160 & & \\
\hline PGSP0262 & Jun/01/1993 & $16: 29$ & 3.60 & & & & 0.660 & 1.000 & & \\
\hline PGSP0263 & Jun/02/1993 & $4: 29$ & 3.60 & & & & 0.600 & 0.780 & & \\
\hline PGSP0264 & Jun/02/1993 & $14: 30$ & 3.40 & 2.300 & $<0.260$ & & 0.550 & 0.700 & 0.370 & 0.080 \\
\hline PGSP0265 & Jun/08/1993 & $17: 14$ & 2.00 & & & & 0.100 & 0.260 & & \\
\hline PGSP0266 & Jun/16/1993 & $6: 05$ & 2.00 & & & & $<0.070$ & 0.130 & & \\
\hline PGSP0267 & Jun/24/1993 & $9: 23$ & 1.60 & & & & $<0.070$ & 0.080 & & \\
\hline PGSP0268 & Jun/24/1993 & $19: 52$ & 1.90 & & & & $<0.070$ & 0.180 & & \\
\hline PGSP0269 & Jun/24/1993 & $20: 52$ & 2.10 & & & & $<0.070$ & $<0.060$ & & \\
\hline PGSP0270 & Jun/24/1993 & $21: 52$ & 1.70 & & & & $<0.070$ & 0.061 & & \\
\hline PGSP0271 & Jun/24/1993 & $22: 52$ & 1.50 & & & & $<0.070$ & 0.130 & & \\
\hline PGSP0272 & Jun/24/1993 & $23: 52$ & 1.80 & & & & $<0.070$ & 0.160 & & \\
\hline PGSP0273 & Jun/25/1993 & $0: 52$ & 1.80 & & & & $<0.070$ & 0.150 & & \\
\hline PGSP0274 & Jun/25/1993 & $1: 52$ & 1.70 & & & & $<0.070$ & 0.110 & & \\
\hline PGSP0275 & Jun/25/1993 & $2: 52$ & 1.90 & & & & $<0.070$ & 0.180 & & \\
\hline PGSP0276 & Jun/25/1993 & $3: 52$ & 1.80 & & & & $<0.070$ & 0.210 & & \\
\hline PGSP0277 & Jun/25/1993 & $4: 52$ & 1.80 & & & & $<0.070$ & 0.110 & & \\
\hline PGSP0278 & Jun/25/1993 & $7: 52$ & 1.40 & & & & $<0.070$ & 0.110 & & \\
\hline PGSP0279 & Jun/25/1993 & $10: 52$ & 1.50 & & & & $<0.070$ & 0.140 & & \\
\hline PGSP0280 & Jun/25/1993 & $13: 52$ & 1.60 & & & & $<0.070$ & 0.150 & & \\
\hline PGSP0281 & Jun/25/1993 & $16: 52$ & 1.60 & & & & $<0.070$ & 0.089 & & \\
\hline PGSP0282 & Jun/25/1993 & $19: 52$ & 1.40 & & & & $<0.070$ & 0.170 & & \\
\hline PGSP0283 & Jun/25/1993 & $22: 52$ & 1.50 & & & & $<0.070$ & 0.120 & & \\
\hline PGSP0284 & Jun/26/1993 & $1: 52$ & 1.40 & & & & $<0.070$ & 0.430 & & \\
\hline PGSP0285 & Jun/26/1993 & $4: 52$ & 1.60 & & & & $<0.070$ & 1.300 & & \\
\hline PGSP0286 & Jun/26/1993 & $7: 52$ & 0.82 & & & & $<0.070$ & 1.300 & & \\
\hline PGSP0287 & Jun/26/1993 & $10: 52$ & 1.80 & & & & 0.083 & 1.200 & & \\
\hline PGSP0288 & Jun/26/1993 & $22: 52$ & 1.90 & & & & 0.077 & 0.840 & & \\
\hline
\end{tabular}

${ }^{*}$ These statistics are presented as a descriptive summary of the table. The effects of aliasing and variable sampling intervals may significantly affect the validity of averages presented as representative of ground-water quality in the basin. No data means an analysis was not performed. 
Pleasant Grove Spring, October 1992-September 1993

\begin{tabular}{|c|c|c|c|c|c|c|c|c|c|c|}
\hline $\begin{array}{l}\text { Sample } \\
\text { Number }\end{array}$ & Date & Time (CST) & $\begin{array}{c}\text { Total ELISA } \\
\text { Triazines } \\
(\mu g / L)\end{array}$ & $\begin{array}{c}\text { Total GC } \\
\text { Atrazine } \\
(\mu \mathrm{g} / \mathrm{L})\end{array}$ & $\begin{array}{c}\text { Total GC } \\
\text { Simazine } \\
(\mu \mathrm{g} / \mathrm{L})\end{array}$ & $\begin{array}{c}\text { Total GC } \\
\text { Cyanazine } \\
(\mu \mathrm{g} / \mathrm{L})\end{array}$ & $\begin{array}{c}\text { Total ELISA } \\
\text { Carbofuran } \\
(\mu g / L)\end{array}$ & $\begin{array}{c}\text { Total ELISA } \\
\text { Metolachlor } \\
(\mu g / L)\end{array}$ & $\begin{array}{c}\text { Total GC } \\
\text { Metolachlor } \\
(\mu \mathrm{g} / \mathrm{L})\end{array}$ & $\begin{array}{c}\text { Total GC } \\
\text { Alachlor } \\
(\mu \mathrm{g} / \mathrm{L})\end{array}$ \\
\hline PGSP0289 & Jun/27/1993 & $10: 52$ & 1.80 & & & & $<0.070$ & 0.320 & & \\
\hline PGSP0290 & Jun/27/1993 & $22: 52$ & 0.96 & & & & $<0.070$ & 0.180 & & \\
\hline PGSP0291 & Jun/28/1993 & $10: 52$ & 1.50 & & & & $<0.070$ & 0.130 & & \\
\hline PGSP0292 & Jun/29/1993 & $11: 00$ & 1.80 & 0.910 & $<0.260$ & $<0.240$ & $<0.070$ & 0.160 & 0.088 & $<0.018$ \\
\hline PGSP0293 & Jul/02/1993 & $16: 04$ & 1.50 & & & & $<0.070$ & 0.180 & & \\
\hline PGSP0294 & Jul/03/1993 & 13:04 & 1.40 & & & & $<0.070$ & 0.100 & & \\
\hline PGSP0295 & Jul/15/1993 & $12: 08$ & 1.20 & & & & $<0.070$ & 0.060 & & \\
\hline PGSP0296 & Jul/16/1993 & $11: 29$ & 1.40 & & & & $<0.070$ & 0.670 & & \\
\hline PGSP0297 & Jul/22/1993 & $11: 17$ & 1.20 & & & & $<0.070$ & 0.660 & & \\
\hline PGSP0298 & Jul/29/1993 & $9: 46$ & 1.30 & & & & $<0.070$ & 0.060 & & \\
\hline PGSP0299 & Aug/04/1993 & 9:00 & 1.10 & 0.660 & $<0.260$ & $<0.240$ & $<0.070$ & 0.067 & 0.081 & $<0.018$ \\
\hline PGSP0300 & Aug/14/1993 & $15: 53$ & 1.00 & & & & $<0.070$ & $<0.060$ & & \\
\hline PGSP0301 & Aug/24/1993 & $12: 18$ & 0.97 & & & & $<0.070$ & 0.060 & & \\
\hline PGSP0302 & Sep/09/1993 & $7: 30$ & 0.80 & 0.400 & $<0.260$ & & $<0.070$ & $<0.060$ & 0.033 & $<0.018$ \\
\hline \multirow{6}{*}{\multicolumn{2}{|c|}{\begin{tabular}{|l} 
\\
\\
\\
\end{tabular}}} & Average* & 4.837 & 2.873 & 0.231 & 0.583 & 0.137 & 0.891 & 0.457 & 0.459 \\
\hline & & Maximum & 44.00 & 28.000 & 0.360 & 4.400 & 0.950 & 9.600 & 5.100 & 6.1 \\
\hline & & Minimum & $<0.06$ & 0.260 & $<0.160$ & $<0.150$ & $<0.070$ & $<0.060$ & $<0.031$ & $<0.018$ \\
\hline & & Stand. Dev. & 10.829 & 7.934 & 0.073 & 1.267 & 1.930 & 2.181 & 1.398 & 1.624 \\
\hline & & Coef. Var. & 2.239 & 2.761 & 0.314 & 2.174 & 1.408 & 2.448 & 3.058 & 3.541 \\
\hline & & No. Analyses & 184 & 11 & 13 & 10 & 183 & 184 & 12 & 14 \\
\hline
\end{tabular}

Spring Valley karst window, October 1992-September 1993

\begin{tabular}{|c|c|c|c|c|c|c|c|c|c|c|}
\hline $\begin{array}{l}\text { Sample } \\
\text { Number }\end{array}$ & Date & Time (CST) & $\begin{array}{c}\text { Total ELISA } \\
\text { Triazines } \\
(\mu \mathrm{g} / \mathrm{L})\end{array}$ & $\begin{array}{c}\text { Total GC } \\
\text { Atrazine } \\
(\mu \mathrm{g} / \mathrm{L})\end{array}$ & $\begin{array}{c}\text { Total GC } \\
\text { Simazine } \\
(\mu g / L)\end{array}$ & $\begin{array}{c}\text { Total GC } \\
\text { Cyanazine } \\
(\mu \mathrm{g} / \mathrm{L})\end{array}$ & $\begin{array}{c}\text { Total ELISA } \\
\text { Carbofuran } \\
(\mu g / L)\end{array}$ & $\begin{array}{c}\text { Total ELISA } \\
\text { Metolachlor } \\
(\mu \mathrm{g} / \mathrm{L})\end{array}$ & $\begin{array}{c}\text { Total GC } \\
\text { Metolachlor } \\
(\mu \mathrm{g} / \mathrm{L})\end{array}$ & $\begin{array}{c}\text { Total GC } \\
\text { Alachlor } \\
(\mu \mathrm{g} / \mathrm{L})\end{array}$ \\
\hline SVKW0015 & May/20/1993 & $9: 20$ & 2.80 & & & & $<0.070$ & 0.840 & & \\
\hline SVKW0016 & May/26/1993 & $12: 10$ & 2.00 & & & & $<0.070$ & 0.180 & & \\
\hline SVKW0017 & Jun/02/1993 & $12: 55$ & 2.90 & & & & 0.540 & 0.650 & & \\
\hline & & Average $^{*}$ & 2.567 & & & & & 0.557 & & \\
\hline & & Maximum & 2.90 & & & & 0.540 & 0.840 & & \\
\hline & & Minimum & 2.00 & & & & $<0.070$ & 0.180 & & \\
\hline & & No. Analyses & 3 & & & & 3 & 3 & & \\
\hline
\end{tabular}

*These statistics are presented as a descriptive summary of the table. The effects of aliasing and variable sampling intervals may significantly affect the validity of averages presented as representative of ground-water quality in the basin. No data means an analysis was not performed. 
George Delaney swallow hole, October 1992-September 1993

\begin{tabular}{|c|c|c|c|c|c|c|c|c|c|c|}
\hline $\begin{array}{l}\text { Sample } \\
\text { Number }\end{array}$ & Date & Time (CST) & $\begin{array}{c}\text { Total ELISA } \\
\text { Triazines } \\
(\mu g / L)\end{array}$ & $\begin{array}{c}\text { Total GC } \\
\text { Atrazine } \\
(\mu \mathrm{g} / \mathrm{L})\end{array}$ & $\begin{array}{c}\text { Total GC } \\
\text { Simazine } \\
(\mu g / L)\end{array}$ & $\begin{array}{c}\text { Total GC } \\
\text { Cyanazine } \\
(\mu \mathrm{g} / \mathrm{L})\end{array}$ & $\begin{array}{c}\text { Total ELISA } \\
\text { Carbofuran } \\
(\mu g / L)\end{array}$ & $\begin{array}{c}\text { Total ELISA } \\
\text { Metolachlor } \\
(\mu g / L)\end{array}$ & $\begin{array}{c}\text { Total GC } \\
\text { Metolachlor } \\
(\mu \mathrm{g} / \mathrm{L})\end{array}$ & $\begin{array}{c}\text { Total GC } \\
\text { Alachlor } \\
(\mu g / L)\end{array}$ \\
\hline GDSW0009 & May/20/1993 & $8: 14$ & 2.600 & & & & $<0.070$ & 1.000 & & \\
\hline GDSW0010 & May/26/1993 & $11: 50$ & 1.900 & & & & $<0.070$ & $<0.060$ & & \\
\hline GDSW010A & Jun/03/1993 & $8: 45$ & 3.100 & & & & & 0.390 & & \\
\hline GDSW0011 & Jun/17/1993 & $8: 20$ & 2.100 & & & & $<0.070$ & $<0.060$ & & \\
\hline & & Average $^{\star}$ & 2.425 & & & & & & & \\
\hline & & Maximum & 3.100 & & & & $<0.070$ & 1.000 & & \\
\hline & & Minimum & 1.900 & & & & & $<0.060$ & & \\
\hline & & No. Analyses & $\overline{4}$ & & & & $\overline{3}$ & $\overline{4}$ & & \\
\hline
\end{tabular}

${ }^{*}$ These statistics are presented as a descriptive summary of the table. The effects of aliasing and variable sampling intervals may significantly affect the validity of averages presented as representative of ground-water quality in the basin. No data means an analysis was not performed. 
Leslie Page karst window, October 1992-September 1993

\begin{tabular}{|c|c|c|c|c|c|c|c|c|c|c|}
\hline $\begin{array}{l}\text { Sample } \\
\text { Number }\end{array}$ & Date & Time (CST) & $\begin{array}{c}\text { Total ELISA } \\
\text { Triazines } \\
(\mu g / L)\end{array}$ & $\begin{array}{c}\text { Total GC } \\
\text { Atrazine } \\
(\mu \mathrm{g} / \mathrm{L})\end{array}$ & $\begin{array}{c}\text { Total GC } \\
\text { Simazine } \\
(\mu g / L)\end{array}$ & $\begin{array}{c}\text { Total GC } \\
\text { Cyanazine } \\
(\mu g / L)\end{array}$ & $\begin{array}{c}\text { Total ELISA } \\
\text { Carbofuran } \\
(\mu g / L)\end{array}$ & $\begin{array}{c}\text { Total ELISA } \\
\text { Metolachlor } \\
(\mu \mathrm{g} / \mathrm{L})\end{array}$ & $\begin{array}{c}\text { Total GC } \\
\text { Metolachlor } \\
(\mu g / L)\end{array}$ & $\begin{array}{c}\text { Total GC } \\
\text { Alachlor } \\
(\mu \mathrm{g} / \mathrm{L})\end{array}$ \\
\hline LPKW0001 & Apr/10/1993 & $18: 00$ & 0.25 & & & & $<0.070$ & $<0.060$ & & \\
\hline LPKW0002 & Apr/11/1993 & $6: 00$ & 0.36 & & & & $<0.070$ & $<0.060$ & & \\
\hline LPKW0003 & Apr/11/1993 & $18: 00$ & 0.25 & & & & $<0.070$ & $<0.060$ & & \\
\hline LPKW0004 & Apr/12/1993 & $6: 00$ & 0.34 & & & & $<0.070$ & $<0.060$ & & \\
\hline LPKW0005 & Apr/12/1993 & $18: 00$ & 0.29 & & & & $<0.070$ & $<0.060$ & & \\
\hline LPKW0006 & Apr/13/1993 & $6: 00$ & 0.34 & & & & $<0.070$ & $<0.060$ & & \\
\hline LPKW0007 & May/05/1993 & $8: 17$ & 2.00 & & & & $<0.070$ & $<0.060$ & & \\
\hline LPKW0009 & May/20/1993 & $11: 10$ & 1.10 & & & & $<0.070$ & $<0.060$ & & \\
\hline LPKW0010 & May/26/1993 & $11: 30$ & 0.40 & & & & $<0.070$ & $<0.060$ & & \\
\hline LPKW010A & Jun/02/1993 & $16: 50$ & 0.64 & & & & $<0.070$ & $<0.060$ & & \\
\hline LPKW0011 & Jun/08/1993 & $8: 34$ & 0.45 & & & & $<0.070$ & $<0.060$ & & \\
\hline LPKW0012 & Jun/17/1993 & $9: 50$ & 0.37 & & & & $<0.070$ & $<0.060$ & & \\
\hline LPKW0013 & Jun/24/1993 & $10: 00$ & 0.44 & & & & $<0.070$ & $<0.060$ & & \\
\hline \begin{tabular}{|l} 
LPKW0014 \\
\end{tabular} & Jun/30/1993 & $9: 45$ & 0.47 & & & & $<0.070$ & 0.082 & & \\
\hline LPKW0015 & Jul/15/1993 & $11: 22$ & 0.28 & & & & $<0.070$ & $<0.060$ & & \\
\hline LPKW0016 & Jul/22/1993 & $10: 19$ & 0.30 & & & & $<0.070$ & 0.490 & & \\
\hline $\begin{array}{l}\text { LPKW0017 } \\
\end{array}$ & Jul/29/1993 & $10: 32$ & 0.41 & & & & $<0.070$ & $<0.060$ & & \\
\hline \multicolumn{3}{|r|}{ Average $^{*}$} & 0.511 & & & & & 0.087 & & \\
\hline \multicolumn{3}{|r|}{ Maximum } & 2.00 & & & & $<0.070$ & 0.490 & & \\
\hline \multicolumn{3}{|r|}{ Minimum } & 0.25 & & & & & $<0.060$ & & \\
\hline \multicolumn{3}{|r|}{ Stand. Dev. } & 0.433 & & & & & 0.104 & & \\
\hline \multicolumn{3}{|r|}{ Coef. Var. } & 0.847 & & & & & 1.202 & & \\
\hline \multicolumn{3}{|r|}{ No. Analyses } & $\overline{177}$ & & & & $\overline{17}$ & $\overline{177}$ & & \\
\hline
\end{tabular}

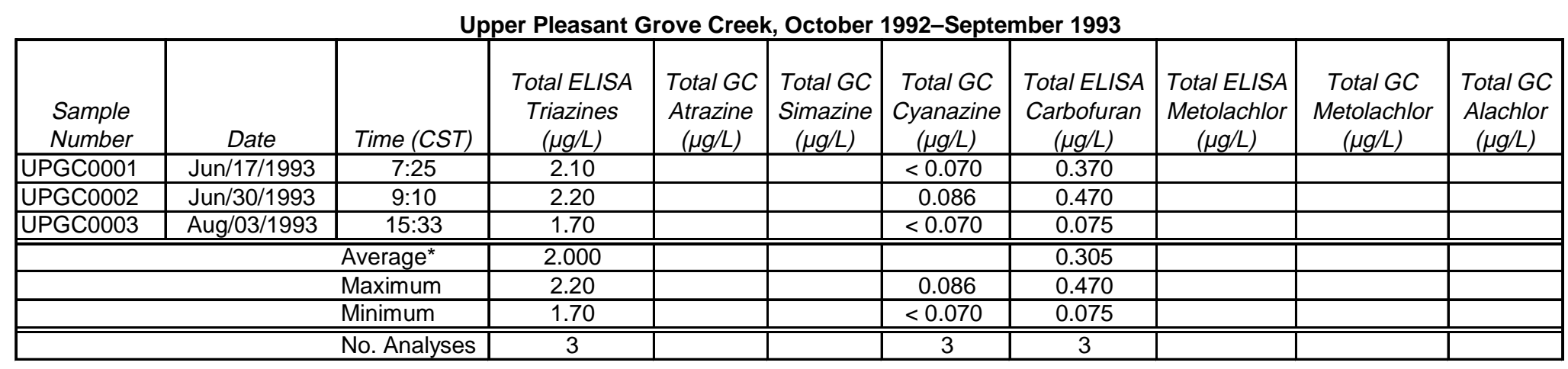

${ }^{*}$ These statistics are presented as a descriptive summary of the table. The effects of aliasing and variable sampling intervals may significantly affect the validity of averages presented as representative of ground-water quality in the basin. No data means an analysis was not performed. 
Pleasant Grove Spring, October 1993-September 1994

\begin{tabular}{|c|c|c|c|c|c|c|c|c|c|c|}
\hline $\begin{array}{l}\text { Sample } \\
\text { Number }\end{array}$ & Date & Time (CST) & $\begin{array}{c}\text { Total ELISA } \\
\text { Triazines } \\
(\mu g / L)\end{array}$ & $\begin{array}{c}\text { Total GC } \\
\text { Atrazine } \\
(\mu g / L)\end{array}$ & $\begin{array}{c}\text { Total GC } \\
\text { Simazine } \\
(\mu \mathrm{g} / \mathrm{L})\end{array}$ & $\begin{array}{c}\text { Total GC } \\
\text { Cyanazine } \\
(\mu \mathrm{g} / \mathrm{L})\end{array}$ & $\begin{array}{c}\text { Total ELISA } \\
\text { Carbofuran } \\
(\mu g / L)\end{array}$ & $\begin{array}{c}\text { Total ELISA } \\
\text { Metolachlor } \\
(\mu g / L)\end{array}$ & $\begin{array}{c}\text { Total GC } \\
\text { Metolachlor } \\
(\mu \mathrm{g} / \mathrm{L})\end{array}$ & $\begin{array}{c}\text { Total GC } \\
\text { Alachlor } \\
(\mu \mathrm{g} / \mathrm{L})\end{array}$ \\
\hline PGSP0303 & Oct/06/1993 & $7: 30$ & 0.63 & 0.420 & $<0.260$ & & $<0.070$ & $<0.060$ & 0.031 & $<0.018$ \\
\hline PGSP0304 & Nov/09/1993 & $10: 45$ & 0.63 & 0.420 & $<0.260$ & & $<0.070$ & $<0.031$ & $<0.031$ & \\
\hline PGSP0305 & Nov/18/1993 & $12: 37$ & 0.51 & & & & $<0.070$ & 0.080 & & \\
\hline PGSP0306 & $\mathrm{Dec} / 08 / 1993$ & $9: 30$ & 1.50 & & & & $<0.070$ & $<0.060$ & & \\
\hline PGSP0307 & $\mathrm{Dec} / 09 / 1993$ & $21: 04$ & 1.10 & & & & $<0.070$ & $<0.060$ & & 0.067 \\
\hline PGSP0308 & $\mathrm{Dec} / 09 / 1993$ & $22: 04$ & 1.00 & & & & & & & \\
\hline PGSP0309 & $\mathrm{Dec} / 09 / 1993$ & $23: 04$ & 1.10 & & & & & & & \\
\hline PGSP0310 & $\mathrm{Dec} / 10 / 1993$ & $0: 04$ & 1.20 & & & & & & & \\
\hline PGSP0311 & $\mathrm{Dec} / 10 / 1993$ & $1: 04$ & 1.00 & & & & & & & \\
\hline PGSP0312 & $\mathrm{Dec} / 10 / 1993$ & $2: 04$ & 0.99 & & & & $<0.070$ & $<0.060$ & & \\
\hline PGSP0313 & $\mathrm{Dec} / 10 / 1993$ & $3: 04$ & 1.20 & & & & & & & \\
\hline PGSP0314 & Dec/10/1993 & $4: 04$ & 1.10 & & & & & & & \\
\hline PGSP0315 & $\mathrm{Dec} / 10 / 1993$ & $5: 04$ & 1.00 & & & & & & & \\
\hline PGSP0316 & $\mathrm{Dec} / 10 / 1993$ & $6: 04$ & 1.30 & & & & & & & \\
\hline PGSP0317 & $\mathrm{Dec} / 10 / 1993$ & 9:04 & 0.87 & & & & $<0.070$ & 0.064 & & \\
\hline PGSP0318 & $\mathrm{Dec} / 10 / 1993$ & $12: 04$ & 0.68 & & & & & & & \\
\hline PGSP0319 & $\mathrm{Dec} / 10 / 1993$ & $15: 04$ & 0.94 & & & & & & & \\
\hline PGSP0320 & $\mathrm{Dec} / 10 / 1993$ & $18: 04$ & 0.85 & & & & & & & \\
\hline PGSP0321 & $\mathrm{Dec} / 10 / 1993$ & $21: 04$ & 0.98 & & & & & & & \\
\hline PGSP0322 & $\mathrm{Dec} / 11 / 1993$ & $0: 04$ & 1.10 & & & & & & & \\
\hline PGSP0323 & Dec/11/1993 & $3: 04$ & 1.00 & & & & & & & \\
\hline PGSP0324 & $\mathrm{Dec} / 11 / 1993$ & $6: 04$ & 1.10 & & & & & & & \\
\hline PGSP0325 & $\mathrm{Dec} / 11 / 1993$ & 9:04 & 1.20 & & & & & & & \\
\hline PGSP0326 & $\mathrm{Dec} / 11 / 1993$ & $12: 04$ & 1.00 & & & & $<0.070$ & $<0.060$ & & \\
\hline PGSP0327 & $\mathrm{Dec} / 12 / 1993$ & $0: 04$ & 1.20 & & & & & & & \\
\hline PGSP0328 & $\mathrm{Dec} / 12 / 1993$ & $12: 04$ & 1.00 & & & & $<0.070$ & $<0.060$ & & \\
\hline PGSP0329 & $\mathrm{Dec} / 13 / 1993$ & $0: 04$ & 1.40 & & & & & & & \\
\hline PGSP0330 & $\mathrm{Dec} / 13 / 1993$ & 12:04 & 0.88 & & & & $<0.070$ & $<0.060$ & & \\
\hline PGSP0332 & Dec/29/1993 & $12: 55$ & 0.87 & & & & $<0.080$ & $<0.080$ & & \\
\hline PGSP0333 & Jan/02/1994 & $3: 55$ & 0.83 & & & & $<0.080$ & $<0.080$ & & \\
\hline PGSP0334 & Jan/12/1994 & $11: 40$ & 0.94 & & & & $<0.080$ & $<0.080$ & & \\
\hline PGSP0335 & Jan/24/1994 & $17: 24$ & 0.57 & & & & $<0.080$ & $<0.080$ & & \\
\hline PGSP0336 & Jan/24/1994 & $20: 24$ & 0.49 & & & & $<0.080$ & $<0.080$ & & \\
\hline PGSP0337 & Jan/25/1994 & $8: 24$ & 0.62 & & & & $<0.080$ & $<0.080$ & & \\
\hline PGSP0338 & Jan/25/1994 & $20: 24$ & 0.50 & & & & $<0.080$ & $<0.080$ & & \\
\hline
\end{tabular}

*These statistics are presented as a descriptive summary of the table. The effects of aliasing and variable sampling intervals may significantly affect the validity of averages presented as representative of ground-water quality in the basin. No data means an analysis was not performed. 
Pleasant Grove Spring, October 1993-September 1994

\begin{tabular}{|c|c|c|c|c|c|c|c|c|c|c|}
\hline $\begin{array}{l}\text { Sample } \\
\text { Number }\end{array}$ & Date & Time (CST) & $\begin{array}{c}\text { Total ELISA } \\
\text { Triazines } \\
(\mu g / L)\end{array}$ & $\begin{array}{c}\text { Total GC } \\
\text { Atrazine } \\
(\mu g / L)\end{array}$ & $\begin{array}{c}\text { Total GC } \\
\text { Simazine } \\
(\mu g / L)\end{array}$ & $\begin{array}{c}\text { Total GC } \\
\text { Cyanazine } \\
(\mu \mathrm{g} / \mathrm{L})\end{array}$ & $\begin{array}{c}\text { Total ELISA } \\
\text { Carbofuran } \\
(\mu g / L)\end{array}$ & $\begin{array}{c}\text { Total ELISA } \\
\text { Metolachlor } \\
(\mu g / L)\end{array}$ & $\begin{array}{c}\text { Total GC } \\
\text { Metolachlor } \\
(\mu \mathrm{g} / \mathrm{L})\end{array}$ & $\begin{array}{c}\text { Total GC } \\
\text { Alachlor } \\
(\mu \mathrm{g} / \mathrm{L})\end{array}$ \\
\hline PGSP0339 & Jan/26/1994 & $8: 24$ & 0.53 & & & & $<0.080$ & $<0.080$ & & \\
\hline PGSP0340 & Jan/26/1994 & $20: 24$ & 0.76 & & & & $<0.080$ & $<0.080$ & & \\
\hline PGSP0341 & Jan/27/1994 & $8: 50$ & 0.87 & & & & $<0.080$ & $<0.080$ & & \\
\hline PGSP0342 & Feb/02/1994 & $12: 10$ & $<0.07$ & & & & $<0.080$ & $<0.080$ & & \\
\hline PGSP0343 & Feb/22/1994 & $11: 20$ & 0.72 & 0.320 & $<0.350$ & & $<0.080$ & $<0.080$ & $<0.023$ & $<0.017$ \\
\hline PGSP0344 & Mar/01/1994 & 11:00 & 0.69 & & & & $<0.080$ & $<0.080$ & & \\
\hline PGSP0345 & Mar/09/1994 & $9: 00$ & 1.30 & & & & $<0.080$ & 0.280 & & \\
\hline PGSP0346 & Mar/15/1994 & $15: 57$ & 1.50 & & & & $<0.080$ & 0.350 & & \\
\hline PGSP0347 & Mar/27/1994 & $5: 30$ & 1.00 & & & & $<0.080$ & 0.170 & & \\
\hline PGSP0348 & Mar/27/1994 & $6: 10$ & 0.91 & & & & $<0.080$ & 0.140 & & \\
\hline PGSP0349 & Mar/27/1994 & $6: 50$ & 0.90 & & & & $<0.080$ & 0.087 & & \\
\hline PGSP0350 & Mar/27/1994 & $7: 30$ & 0.72 & & & & $<0.080$ & $<0.080$ & & \\
\hline PGSP0351 & Mar/27/1994 & $8: 10$ & 1.20 & & & & $<0.080$ & $<0.080$ & & \\
\hline PGSP0352 & Mar/27/1994 & $9: 30$ & 1.40 & & & & $<0.080$ & $<0.080$ & & \\
\hline PGSP0353 & Mar/27/1994 & $11: 30$ & 2.00 & & & & $<0.080$ & $<0.080$ & & \\
\hline PGSP0354 & Mar/27/1994 & $13: 30$ & 2.60 & & & & $<0.080$ & 0.099 & & \\
\hline PGSP0355 & Mar/27/1994 & $14: 30$ & 2.40 & & & & $<0.080$ & 0.100 & & \\
\hline PGSP0356 & Mar/27/1994 & $15: 30$ & 2.70 & & & & $<0.080$ & 0.150 & & \\
\hline PGSP0357 & Mar/27/1994 & $16: 30$ & 2.40 & & & & $<0.080$ & 0.100 & & \\
\hline PGSP0358 & Mar/27/1994 & $17: 30$ & 1.10 & & & & $<0.080$ & 0.110 & & \\
\hline PGSP0359 & Mar/27/1994 & $18: 30$ & 1.90 & & & & $<0.080$ & 0.210 & & \\
\hline PGSP0360 & Mar/27/1994 & $22: 30$ & 1.60 & & & & $<0.080$ & 0.130 & & \\
\hline PGSP0361 & Mar/28/1994 & $2: 30$ & 1.90 & & & & $<0.080$ & 0.170 & & \\
\hline PGSP0362 & Mar/28/1994 & $6: 30$ & 1.90 & & & & $<0.080$ & 0.140 & & \\
\hline PGSP0363 & Mar/28/1994 & $10: 30$ & 1.90 & & & & $<0.080$ & 0.120 & & \\
\hline PGSP0364 & Mar/28/1994 & $13: 00$ & 2.00 & 1.150 & $<0.100$ & $<0.500$ & $<0.080$ & $<0.250$ & & \\
\hline PGSP0365 & Mar/28/1994 & $18: 00$ & 1.50 & & & & $<0.080$ & 0.170 & & \\
\hline PGSP0366 & Mar/29/1994 & $6: 00$ & 1.20 & & & & $<0.080$ & 0.190 & & \\
\hline PGSP0367 & Mar/29/1994 & $18: 00$ & 1.30 & & & & $<0.080$ & 0.170 & & \\
\hline PGSP0368 & Mar/30/1994 & $6: 00$ & 1.20 & & & & $<0.080$ & 0.140 & & \\
\hline PGSP0369 & Mar/30/1994 & $18: 00$ & 1.20 & & & & $<0.080$ & 0.160 & & \\
\hline PGSP0370 & Mar/31/1994 & $6: 00$ & 1.20 & & & & $<0.080$ & 0.160 & & \\
\hline PGSP0371 & Mar/31/1994 & $18: 00$ & 1.10 & & & & $<0.080$ & 0.160 & & \\
\hline PGSP0372 & Apr/01/1994 & $6: 00$ & 1.10 & & & & $<0.080$ & 0.110 & & \\
\hline
\end{tabular}

*These statistics are presented as a descriptive summary of the table. The effects of aliasing and variable sampling intervals may significantly affect the validity of averages presented as representative of ground-water quality in the basin. No data means an analysis was not performed. 
Pleasant Grove Spring, October 1993-September 1994

\begin{tabular}{|c|c|c|c|c|c|c|c|c|c|c|}
\hline $\begin{array}{l}\text { Sample } \\
\text { Number }\end{array}$ & Date & Time (CST) & $\begin{array}{c}\text { Total ELISA } \\
\text { Triazines } \\
(\mu g / L)\end{array}$ & $\begin{array}{c}\text { Total GC } \\
\text { Atrazine } \\
(\mu \mathrm{g} / \mathrm{L})\end{array}$ & $\begin{array}{c}\text { Total GC } \\
\text { Simazine } \\
(\mu g / L)\end{array}$ & $\begin{array}{c}\text { Total GC } \\
\text { Cyanazine } \\
(\mu g / L)\end{array}$ & $\begin{array}{c}\text { Total ELISA } \\
\text { Carbofuran } \\
(\mu g / L)\end{array}$ & $\begin{array}{c}\text { Total ELISA } \\
\text { Metolachlor } \\
(\mu \mathrm{g} / \mathrm{L})\end{array}$ & $\begin{array}{c}\text { Total GC } \\
\text { Metolachlor } \\
(\mu \mathrm{g} / \mathrm{L})\end{array}$ & $\begin{array}{c}\text { Total GC } \\
\text { Alachlor } \\
(\mu g / L)\end{array}$ \\
\hline PGSP0373 & Apr/01/1994 & $18: 00$ & 1.30 & & & & $<0.080$ & 0.110 & & \\
\hline PGSP0374 & Apr/02/1994 & $6: 00$ & 1.30 & & & & $<0.080$ & 0.160 & & \\
\hline PGSP0375 & Apr/02/1994 & $18: 00$ & 1.30 & & & & $<0.080$ & 0.140 & & \\
\hline PGSP0376 & Apr/03/1994 & $6: 00$ & 1.30 & & & & $<0.080$ & 0.140 & & \\
\hline PGSP0377 & Apr/03/1994 & $18: 00$ & 1.20 & & & & $<0.080$ & 0.130 & & \\
\hline PGSP0378 & Apr/04/1994 & $6: 00$ & 1.20 & & & & $<0.080$ & 0.140 & & \\
\hline PGSP0379 & Apr/04/1994 & $18: 00$ & 1.10 & & & & $<0.080$ & 0.130 & & \\
\hline PGSP0380 & Apr/05/1994 & $6: 00$ & 1.20 & & & & $<0.080$ & 0.110 & & \\
\hline PGSP0381 & Apr/05/1994 & $18: 00$ & 1.20 & & & & $<0.080$ & 0.150 & & \\
\hline PGSP0382 & Apr/06/1994 & $6: 00$ & 0.93 & & & & $<0.080$ & 0.120 & & \\
\hline PGSP0383 & Apr/06/1994 & $18: 00$ & 1.90 & & & & $<0.080$ & 0.200 & & \\
\hline PGSP0384 & Apr/07/1994 & $6: 00$ & 2.40 & & & & $<0.080$ & 0.230 & & \\
\hline PGSP0385 & Apr/07/1994 & $14: 00$ & 2.10 & & & & $<0.080$ & 0.300 & & \\
\hline PGSP0387 & Apr/11/1994 & $14: 13$ & 3.10 & & & & $<0.080$ & $<0.080$ & & \\
\hline PGSP0388 & Apr/11/1994 & $17: 57$ & 3.00 & & & & $<0.080$ & 0.980 & & \\
\hline PGSP0389 & Apr/12/1994 & $7: 30$ & 2.90 & & & & $<0.080$ & 0.320 & & \\
\hline PGSP0391 & Apr/12/1994 & $15: 30$ & 2.50 & & & & $<0.080$ & 0.200 & & \\
\hline PGSP0392 & Apr/13/1994 & $6: 15$ & 2.60 & & & & $<0.080$ & 0.260 & & \\
\hline PGSP0393 & Apr/13/1994 & $18: 00$ & 2.20 & & & & $<0.080$ & 0.130 & & \\
\hline PGSP0394 & Apr/14/1994 & $6: 00$ & 1.90 & & & & $<0.080$ & 0.130 & & \\
\hline PGSP0395 & Apr/14/1994 & $18: 00$ & 1.80 & & & & $<0.080$ & 0.180 & & \\
\hline PGSP0396 & Apr/15/1994 & $6: 00$ & 1.70 & & & & $<0.080$ & 0.180 & & \\
\hline PGSP0397 & Apr/15/1994 & $18: 00$ & 1.60 & & & & 0.170 & 0.120 & & \\
\hline PGSP0398 & Apr/16/1994 & $6: 00$ & 2.50 & & & & $<0.080$ & 0.350 & & \\
\hline PGSP0399 & Apr/16/1994 & $18: 00$ & 2.00 & & & & $<0.080$ & 0.230 & & \\
\hline PGSP0400 & Apr/17/1994 & $6: 00$ & 0.76 & & & & $<0.080$ & 0.200 & & \\
\hline PGSP0401 & Apr/17/1994 & $18: 00$ & 1.80 & & & & $<0.080$ & 0.160 & & \\
\hline PGSP0402 & Apr/18/1994 & $6: 00$ & 1.70 & & & & $<0.080$ & 0.160 & & \\
\hline PGSP0403 & Apr/18/1994 & $18: 00$ & 1.70 & & & & $<0.080$ & 0.140 & & \\
\hline PGSP0404 & Apr/19/1994 & $6: 00$ & 1.60 & & & & $<0.080$ & 0.160 & & \\
\hline PGSP404A & Apr/20/1994 & $6: 00$ & 1.80 & & & & $<0.080$ & 0.340 & & \\
\hline PGSP0405 & Apr/21/1994 & $6: 00$ & 1.80 & & & & $<0.080$ & 0.240 & & \\
\hline PGSP0406 & Apr/22/1994 & $6: 00$ & 1.90 & & & & $<0.080$ & 0.300 & & \\
\hline PGSP0407 & Apr/23/1994 & $6: 00$ & 1.70 & & & & $<0.080$ & 0.290 & & \\
\hline
\end{tabular}

${ }^{*}$ These statistics are presented as a descriptive summary of the table. The effects of aliasing and variable sampling intervals may significantly affect the validity of averages presented as representative of ground-water quality in the basin. No data means an analysis was not performed. 
Pleasant Grove Spring, October 1993-September 1994

\begin{tabular}{|c|c|c|c|c|c|c|c|c|c|c|}
\hline $\begin{array}{l}\text { Sample } \\
\text { Number }\end{array}$ & Date & Time (CST) & $\begin{array}{c}\text { Total ELISA } \\
\text { Triazines } \\
(\mu g / L)\end{array}$ & $\begin{array}{c}\text { Total GC } \\
\text { Atrazine } \\
(\mu g / L)\end{array}$ & $\begin{array}{c}\text { Total GC } \\
\text { Simazine } \\
(\mu g / L)\end{array}$ & $\begin{array}{c}\text { Total GC } \\
\text { Cyanazine } \\
(\mu \mathrm{g} / \mathrm{L})\end{array}$ & $\begin{array}{c}\text { Total ELISA } \\
\text { Carbofuran } \\
(\mu g / L)\end{array}$ & $\begin{array}{c}\text { Total ELISA } \\
\text { Metolachlor } \\
(\mu g / L)\end{array}$ & $\begin{array}{c}\text { Total GC } \\
\text { Metolachlor } \\
(\mu \mathrm{g} / \mathrm{L})\end{array}$ & $\begin{array}{c}\text { Total GC } \\
\text { Alachlor } \\
(\mu \mathrm{g} / \mathrm{L})\end{array}$ \\
\hline PGSP0408 & Apr/24/1994 & $6: 00$ & 1.80 & & & & $<0.080$ & 0.320 & & \\
\hline PGSP0409 & Apr/25/1994 & $6: 00$ & 1.80 & & & & $<0.080$ & 0.340 & & \\
\hline PGSP0410 & Apr/26/1994 & $6: 00$ & 1.80 & & & & $<0.080$ & 0.560 & & \\
\hline PGSP0411 & Apr/27/1994 & $6: 00$ & 1.90 & & & & $<0.080$ & 0.200 & & \\
\hline PGSP0412 & Apr/27/1994 & $10: 00$ & 1.90 & $<0.100$ & $<0.100$ & & $<0.080$ & 0.320 & $<0.250$ & $<0.100$ \\
\hline PGSP0413 & Apr/28/1994 & $6: 00$ & 1.90 & & & & $<0.080$ & 0.290 & & \\
\hline PGSP0414 & Apr/29/1994 & $6: 00$ & 1.80 & & & & $<0.080$ & 0.280 & & \\
\hline PGSP0415 & Apr/29/1994 & $18: 00$ & 1.90 & & & & $<0.080$ & 0.250 & & \\
\hline PGSP0416 & Apr/29/1994 & $18: 45$ & 2.00 & & & & 0.180 & 0.430 & & \\
\hline PGSP0417 & Apr/29/1994 & $19: 05$ & 2.80 & & & & 0.092 & 0.430 & & \\
\hline PGSP0418 & Apr/29/1994 & 19:09 & 2.70 & & & & $<0.080$ & 0.360 & & \\
\hline PGSP0419 & Apr/29/1994 & $19: 25$ & 2.80 & & & & 0.130 & 0.430 & & \\
\hline PGSP0420 & Apr/29/1994 & $19: 45$ & 2.80 & & & & $<0.080$ & 0.450 & & \\
\hline PGSP0421 & Apr/29/1994 & $19: 51$ & 2.60 & & & & $<0.080$ & 0.340 & & \\
\hline PGSP0422 & Apr/29/1994 & $20: 05$ & 2.50 & & & & $<0.080$ & 0.350 & & \\
\hline PGSP0423 & Apr/29/1994 & $20: 25$ & 2.48 & & & & $<0.080$ & 0.400 & & \\
\hline PGSP0424 & Apr/29/1994 & $20: 45$ & 2.30 & & & & $<0.080$ & 0.470 & & \\
\hline PGSP0425 & Apr/29/1994 & $21: 05$ & 1.90 & & & & $<0.080$ & 0.500 & & \\
\hline PGSP0426 & Apr/29/1994 & $21: 25$ & 2.80 & & & & $<0.080$ & 0.330 & & \\
\hline PGSP0427 & Apr/29/1994 & $21: 45$ & 4.80 & & & & $<0.080$ & 0.370 & & \\
\hline PGSP0428 & Apr/29/1994 & $22: 45$ & 7.20 & & & & 1.400 & 1.000 & & \\
\hline PGSP0429 & Apr/29/1994 & $23: 45$ & 6.40 & & & & 5.700 & 1.700 & & \\
\hline PGSP0430 & Apr/30/1994 & $0: 45$ & 6.60 & & & & 7.400 & 1.800 & & \\
\hline PGSP0431 & Apr/30/1994 & $1: 45$ & 6.00 & & & & 5.700 & 1.700 & & \\
\hline PGSP0432 & Apr/30/1994 & $2: 45$ & 6.10 & & & & 3.800 & 2.700 & & \\
\hline PGSP0433 & Apr/30/1994 & $3: 45$ & 6.00 & & & & 3.800 & 3.800 & & \\
\hline PGSP0434 & Apr/30/1994 & $4: 45$ & 6.30 & & & & 4.900 & 4.300 & & \\
\hline PGSP0435 & Apr/30/1994 & $5: 45$ & 5.90 & & & & 5.200 & 4.500 & & \\
\hline PGSP0436 & Apr/30/1994 & $6: 45$ & 6.20 & & & & 5.800 & 4.200 & & \\
\hline PGSP0437 & Apr/30/1994 & $7: 45$ & 5.80 & & & & 4.700 & 3.600 & & \\
\hline PGSP0438 & Apr/30/1994 & $11: 45$ & 5.70 & & & & 3.000 & 2.300 & & \\
\hline PGSP0439 & Apr/30/1994 & $15: 45$ & 5.00 & & & & 1.100 & 1.400 & & \\
\hline PGSP0440 & May/01/1994 & $6: 00$ & 5.80 & & & & 0.220 & 2.100 & & \\
\hline PGSP0441 & May/02/1994 & $6: 00$ & 4.08 & & & & $<0.080$ & 1.200 & & \\
\hline
\end{tabular}

*These statistics are presented as a descriptive summary of the table. The effects of aliasing and variable sampling intervals may significantly affect the validity of averages presented as representative of ground-water quality in the basin. No data means an analysis was not performed. 
Pleasant Grove Spring, October 1993-September 1994

\begin{tabular}{|c|c|c|c|c|c|c|c|c|c|c|}
\hline $\begin{array}{l}\text { Sample } \\
\text { Number }\end{array}$ & Date & Time (CST) & $\begin{array}{c}\text { Total ELISA } \\
\text { Triazines } \\
(\mu g / L)\end{array}$ & $\begin{array}{c}\text { Total GC } \\
\text { Atrazine } \\
(\mu \mathrm{g} / \mathrm{L})\end{array}$ & $\begin{array}{c}\text { Total GC } \\
\text { Simazine } \\
(\mu \mathrm{g} / \mathrm{L})\end{array}$ & $\begin{array}{c}\text { Total GC } \\
\text { Cyanazine } \\
(\mu \mathrm{g} / \mathrm{L})\end{array}$ & $\begin{array}{c}\text { Total ELISA } \\
\text { Carbofuran } \\
(\mu g / L)\end{array}$ & $\begin{array}{c}\text { Total ELISA } \\
\text { Metolachlor } \\
(\mu \mathrm{g} / \mathrm{L})\end{array}$ & $\begin{array}{c}\text { Total GC } \\
\text { Metolachlor } \\
(\mu \mathrm{g} / \mathrm{L})\end{array}$ & $\begin{array}{c}\text { Total GC } \\
\text { Alachlor } \\
(\mu \mathrm{g} / \mathrm{L})\end{array}$ \\
\hline PGSP0442 & May/03/1994 & $6: 00$ & 2.60 & & & & 0.087 & 0.390 & & \\
\hline PGSP0443 & May/04/1994 & $6: 00$ & 3.70 & & & & 0.530 & 0.600 & & \\
\hline PGSP0444 & May/04/1994 & $18: 00$ & 3.30 & & & & 0.530 & 0.680 & & \\
\hline PGSP0445 & May/05/1994 & $6: 00$ & 2.40 & & & & 0.230 & 0.410 & & \\
\hline PGSP0446 & May/07/1994 & $6: 00$ & 1.90 & & & & $<0.080$ & 0.200 & & \\
\hline PGSP0447 & May/09/1994 & $6: 00$ & 2.20 & & & & 0.140 & 0.270 & & \\
\hline PGSP0448 & May/11/1994 & $6: 00$ & 1.80 & & & & 0.096 & 0.190 & & \\
\hline PGSP0449 & May/12/1994 & 9:00 & 1.50 & & & & 0.089 & 0.180 & & \\
\hline PGSP0450 & May/13/1994 & $6: 00$ & 1.40 & & & & $<0.080$ & 0.240 & & \\
\hline PGSP0451 & May/14/1994 & $6: 00$ & 1.50 & & & & $<0.080$ & 0.230 & & \\
\hline PGSP0452 & May/15/1994 & $6: 00$ & 1.60 & & & & $<0.080$ & 0.200 & & \\
\hline PGSP0453 & May/15/1994 & $18: 00$ & 1.50 & & & & $<0.080$ & 0.210 & & \\
\hline PGSP0454 & May/16/1994 & $6: 00$ & 3.50 & & & & $<0.080$ & 0.360 & & \\
\hline PGSP0455 & May/17/1994 & $6: 00$ & 2.50 & & & & $<0.080$ & 0.400 & & \\
\hline PGSP0456 & May/18/1994 & $6: 00$ & 1.70 & & & & $<0.080$ & 0.120 & & \\
\hline PGSP0457 & May/20/1994 & $6: 00$ & 1.40 & & & & $<0.080$ & $<0.080$ & & \\
\hline PGSP0458 & May/22/1994 & $6: 00$ & 1.20 & & & & $<0.080$ & $<0.080$ & & \\
\hline PGSP0459 & May/24/1994 & $6: 00$ & 1.20 & & & & $<0.080$ & $<0.080$ & & \\
\hline PGSP0460 & May/26/1994 & $6: 00$ & 1.20 & & & & $<0.080$ & $<0.080$ & & \\
\hline PGSP0461 & May/28/1994 & $6: 00$ & 1.20 & & & & $<0.080$ & $<0.080$ & & \\
\hline PGSP0462 & May/30/1994 & $6: 00$ & 1.10 & & & & $<0.080$ & $<0.080$ & & \\
\hline PGSP0463 & Jun/01/1994 & $12: 00$ & 1.00 & & & & $<0.080$ & $<0.080$ & & \\
\hline PGSP0464 & Jun/03/1994 & $6: 00$ & 1.00 & & & & & $<0.080$ & & \\
\hline PGSP0465 & Jun/05/1994 & $6: 00$ & 0.99 & & & & & $<0.080$ & & \\
\hline PGSP0466 & Jun/07/1994 & $6: 00$ & 1.10 & & & & & $<0.080$ & & \\
\hline PGSP0467 & Jun/09/1994 & $6: 00$ & 1.20 & & & & & 0.130 & & \\
\hline PGSP0468 & Jun/10/1994 & $6: 00$ & 1.20 & & & & & 0.100 & & \\
\hline PGSP0469 & Jun/10/1994 & $11: 01$ & 1.40 & & & & & 0.150 & & \\
\hline PGSP0470 & Jun/10/1994 & $11: 21$ & 1.30 & & & & & 0.150 & & \\
\hline PGSP0471 & Jun/10/1994 & $11: 41$ & 1.30 & & & & & 0.160 & & \\
\hline PGSP0472 & Jun/10/1994 & $12: 01$ & 1.30 & & & & & 0.120 & & \\
\hline PGSP0473 & Jun/10/1994 & $12: 21$ & 1.30 & & & & & 0.150 & & \\
\hline PGSP0474 & Jun/10/1994 & $12: 41$ & 1.20 & & & & & 0.170 & & \\
\hline PGSP0475 & Jun/10/1994 & $13: 01$ & 1.30 & & & & & 0.130 & & \\
\hline
\end{tabular}

*These statistics are presented as a descriptive summary of the table. The effects of aliasing and variable sampling intervals may significantly affect the validity of averages presented as representative of ground-water quality in the basin. No data means an analysis was not performed. 
Pleasant Grove Spring, October 1993-September 1994

\begin{tabular}{|c|c|c|c|c|c|c|c|c|c|c|}
\hline $\begin{array}{l}\text { Sample } \\
\text { Number }\end{array}$ & Date & Time (CST) & $\begin{array}{c}\text { Total ELISA } \\
\text { Triazines } \\
(\mu g / L)\end{array}$ & $\begin{array}{c}\text { Total GC } \\
\text { Atrazine } \\
(\mu g / L)\end{array}$ & $\begin{array}{c}\text { Total GC } \\
\text { Simazine } \\
(\mu \mathrm{g} / \mathrm{L})\end{array}$ & $\begin{array}{c}\text { Total GC } \\
\text { Cyanazine } \\
(\mu \mathrm{g} / \mathrm{L})\end{array}$ & $\begin{array}{c}\text { Total ELISA } \\
\text { Carbofuran } \\
(\mu g / L)\end{array}$ & $\begin{array}{c}\text { Total ELISA } \\
\text { Metolachlor } \\
(\mu \mathrm{g} / \mathrm{L})\end{array}$ & $\begin{array}{c}\text { Total GC } \\
\text { Metolachlor } \\
(\mu \mathrm{g} / \mathrm{L})\end{array}$ & $\begin{array}{c}\text { Total GC } \\
\text { Alachlor } \\
(\mu \mathrm{g} / \mathrm{L})\end{array}$ \\
\hline PGSP0476 & Jun/10/1994 & $13: 21$ & 1.30 & & & & & 0.170 & & \\
\hline PGSP0477 & Jun/10/1994 & $13: 41$ & 1.30 & & & & & 0.140 & & \\
\hline PGSP0478 & Jun/10/1994 & $14: 01$ & 1.40 & & & & & 0.140 & & \\
\hline PGSP0479 & Jun/10/1994 & $15: 01$ & 1.40 & & & & & 0.150 & & \\
\hline PGSP0480 & Jun/10/1994 & $16: 01$ & 1.30 & & & & & $<0.080$ & & \\
\hline PGSP0481 & Jun/10/1994 & $17: 01$ & 1.30 & & & & & 0.097 & & \\
\hline PGSP0482 & Jun/10/1994 & $18: 01$ & 1.40 & & & & & $<0.080$ & & \\
\hline PGSP0483 & Jun/10/1994 & 19:01 & 1.20 & & & & & $<0.080$ & & \\
\hline PGSP0484 & Jun/10/1994 & $20: 01$ & 1.20 & & & & & $<0.080$ & & \\
\hline PGSP0485 & Jun/10/1994 & $21: 01$ & 1.30 & & & & & $<0.080$ & & \\
\hline PGSP0486 & Jun/10/1994 & $22: 01$ & 1.30 & & & & & $<0.080$ & & \\
\hline PGSP0487 & Jun/10/1994 & $23: 01$ & 1.30 & & & & & $<0.080$ & & \\
\hline PGSP0488 & Jun/11/1994 & $0: 01$ & 1.20 & & & & & $<0.080$ & & \\
\hline PGSP0489 & Jun/11/1994 & $4: 01$ & 1.20 & & & & & $<0.080$ & & \\
\hline PGSP0490 & Jun/11/1994 & $6: 00$ & 1.10 & & & & & $<0.080$ & & \\
\hline PGSP0491 & Jun/11/1994 & $8: 01$ & 1.30 & & & & & $<0.080$ & & \\
\hline PGSP0492 & Jun/11/1994 & $12: 01$ & 1.30 & & & & & $<0.080$ & & \\
\hline PGSP0493 & Jun/11/1994 & $16: 01$ & 1.10 & & & & & $<0.080$ & & \\
\hline PGSP0494 & Jun/14/1994 & $6: 00$ & 1.10 & & & & & $<0.080$ & & \\
\hline PGSP0495 & Jun/16/1994 & $6: 00$ & 0.99 & & & & & $<0.080$ & & \\
\hline PGSP0496 & Jun/17/1994 & $6: 00$ & 1.10 & & & & & $<0.080$ & & \\
\hline PGSP0497 & Jun/17/1994 & $21: 13$ & 1.10 & & & & & $<0.080$ & & \\
\hline PGSP0498 & Jun/17/1994 & $21: 33$ & 1.10 & & & & & $<0.080$ & & \\
\hline PGSP0499 & Jun/17/1994 & $21: 53$ & 1.10 & & & & & $<0.080$ & & \\
\hline PGSP0500 & Jun/17/1994 & $22: 13$ & 1.10 & & & & & $<0.080$ & & \\
\hline PGSP0501 & Jun/17/1994 & $22: 33$ & 1.10 & & & & & $<0.080$ & & \\
\hline PGSP0502 & Jun/17/1994 & $22: 53$ & 1.10 & & & & & $<0.080$ & & \\
\hline PGSP0503 & Jun/17/1994 & $23: 13$ & & & & & & & & \\
\hline PGSP0504 & Jun/17/1994 & $23: 33$ & 1.00 & & & & & $<0.080$ & & \\
\hline PGSP0505 & Jun/17/1994 & $23: 53$ & 1.10 & & & & & $<0.080$ & & \\
\hline PGSP0506 & Jun/18/1994 & $0: 13$ & 1.00 & & & & & $<0.080$ & & \\
\hline PGSP0507 & Jun/18/1994 & $1: 13$ & 1.00 & & & & & $<0.080$ & & \\
\hline PGSP0508 & Jun/18/1994 & $2: 13$ & 2.80 & & & & & 0.440 & & \\
\hline PGSP0509 & Jun/18/1994 & $3: 13$ & 3.50 & & & & & 0.720 & & \\
\hline
\end{tabular}

*These statistics are presented as a descriptive summary of the table. The effects of aliasing and variable sampling intervals may significantly affect the validity of averages presented as representative of ground-water quality in the basin. No data means an analysis was not performed. 
Pleasant Grove Spring, October 1993-September 1994

\begin{tabular}{|c|c|c|c|c|c|c|c|c|c|c|}
\hline $\begin{array}{l}\text { Sample } \\
\text { Number }\end{array}$ & Date & Time (CST) & $\begin{array}{c}\text { Total ELISA } \\
\text { Triazines } \\
(\mu g / L)\end{array}$ & $\begin{array}{c}\text { Total GC } \\
\text { Atrazine } \\
(\mu g / L)\end{array}$ & $\begin{array}{c}\text { Total GC } \\
\text { Simazine } \\
(\mu \mathrm{g} / \mathrm{L}) \\
\end{array}$ & $\begin{array}{c}\begin{array}{c}\text { Total GC } \\
\text { Cyanazine } \\
(\mu \mathrm{g} / \mathrm{L})\end{array} \\
\end{array}$ & $\begin{array}{c}\text { Total ELISA } \\
\text { Carbofuran } \\
(\mu g / L)\end{array}$ & $\begin{array}{c}\text { Total ELISA } \\
\text { Metolachlor } \\
(\mu g / L)\end{array}$ & $\begin{array}{c}\text { Total GC } \\
\text { Metolachlor } \\
(\mu \mathrm{g} / \mathrm{L})\end{array}$ & $\begin{array}{c}\text { Total GC } \\
\text { Alachlor } \\
(\mu g / L)\end{array}$ \\
\hline PGSP0510 & Jun/18/1994 & $4: 13$ & 4.00 & & & & & 1.200 & & \\
\hline PGSP0511 & Jun/18/1994 & $5: 13$ & 3.80 & & & & & 1.500 & & \\
\hline PGSP0512 & Jun/18/1994 & $6: 13$ & 3.80 & & & & & 1.100 & & \\
\hline PGSP0513 & Jun/18/1994 & $7: 13$ & 4.10 & & & & & 1.600 & & \\
\hline PGSP0514 & Jun/18/1994 & $8: 13$ & 4.00 & & & & & 1.800 & & \\
\hline PGSP0515 & Jun/18/1994 & $9: 13$ & 3.90 & & & & & 1.800 & & \\
\hline PGSP0516 & Jun/18/1994 & $10: 13$ & 4.20 & & & & & 1.800 & & \\
\hline PGSP0517 & Jun/18/1994 & $14: 13$ & 3.80 & & & & & 1.500 & & \\
\hline PGSP0518 & Jun/18/1994 & $18: 13$ & 4.30 & & & & & 1.400 & & \\
\hline PGSP0519 & Jun/18/1994 & $22: 13$ & 3.60 & & & & & 1.300 & & \\
\hline PGSP0520 & Jun/19/1994 & $2: 13$ & 3.40 & & & & & 1.100 & & \\
\hline PGSP0521 & Jun/20/1994 & $6: 00$ & 1.40 & & & & & 0.160 & & \\
\hline PGSP0522 & Jun/22/1994 & $6: 00$ & 1.30 & & & & & $<0.080$ & & \\
\hline PGSP0523 & Jun/24/1994 & $6: 00$ & 1.10 & & & & & $<0.080$ & & \\
\hline PGSP0524 & Jun/26/1994 & $6: 00$ & 1.10 & & & & & $<0.080$ & & \\
\hline PGSP0525 & Jun/29/1994 & $6: 00$ & 1.10 & & & & & 0.110 & & \\
\hline PGSP0526 & Jul/01/1994 & $6: 00$ & 1.00 & & & & & 0.110 & & \\
\hline PGSP0527 & Jul/03/1994 & $6: 00$ & 0.98 & & & & & $<0.080$ & & \\
\hline PGSP0528 & Jul/05/1994 & $6: 00$ & 0.88 & & & & & $<0.080$ & & \\
\hline PGSP0529 & Jul/06/1994 & $10: 30$ & 0.98 & & & & & $<0.080$ & & \\
\hline PGSP0530 & Jul/07/1994 & $6: 00$ & 1.00 & & & & & 0.098 & & \\
\hline PGSP0531 & Jul/07/1994 & $6: 30$ & 1.00 & & & & & 0.180 & & \\
\hline PGSP0532 & Jul/07/1994 & $7: 10$ & 1.10 & & & & & 0.270 & & \\
\hline PGSP0533 & Jul/07/1994 & 11:30 & 1.30 & & & & & 3.100 & & \\
\hline PGSP0534 & Jul/13/1994 & $6: 00$ & 1.10 & & & & & 0.210 & & \\
\hline PGSP0535 & Jul/20/1994 & $6: 00$ & 1.00 & & & & & $<0.080$ & & \\
\hline PGSP0537 & Jul/25/1994 & $8: 40$ & 1.00 & & & & & $<0.080$ & & \\
\hline PGSP0538 & Aug/03/1994 & $8: 30$ & 0.80 & & & & & $<0.080$ & & \\
\hline
\end{tabular}

${ }^{*}$ These statistics are presented as a descriptive summary of the table. The effects of aliasing and variable sampling intervals may significantly affect the validity of averages presented as representative of ground-water quality in the basin. No data means an analysis was not performed. 
Pleasant Grove Spring, October 1993-September 1994

\begin{tabular}{|c|c|c|c|c|c|c|c|c|c|c|}
\hline $\begin{array}{l}\text { Sample } \\
\text { Number }\end{array}$ & Date & Time (CST) & $\begin{array}{c}\text { Total ELISA } \\
\text { Triazines } \\
(\mu g / L)\end{array}$ & $\begin{array}{c}\text { Total GC } \\
\text { Atrazine } \\
(\mu \mathrm{g} / \mathrm{L})\end{array}$ & $\begin{array}{c}\text { Total GC } \\
\text { Simazine } \\
(\mu \mathrm{g} / \mathrm{L})\end{array}$ & $\begin{array}{c}\text { Total GC } \\
\text { Cyanazine } \\
(\mu \mathrm{g} / \mathrm{L})\end{array}$ & $\begin{array}{c}\text { Total ELISA } \\
\text { Carbofuran } \\
(\mu g / L)\end{array}$ & $\begin{array}{c}\text { Total ELISA } \\
\text { Metolachlor } \\
(\mu g / L)\end{array}$ & $\begin{array}{c}\text { Total GC } \\
\text { Metolachlor } \\
(\mu \mathrm{g} / \mathrm{L})\end{array}$ & $\begin{array}{c}\text { Total GC } \\
\text { Alachlor } \\
(\mu g / L)\end{array}$ \\
\hline PGSP0539 & Aug/16/1994 & $10: 00$ & 0.63 & & & & & $<0.080$ & & \\
\hline PGSP0540 & Sep/08/1994 & $8: 15$ & 0.60 & & & & & $<0.080$ & & \\
\hline PGSP0541 & Sep/19/1994 & $13: 50$ & 0.64 & & & & & $<0.080$ & & \\
\hline & & Average* $^{\star}$ & 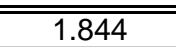 & 0.482 & 0.214 & & 0.458 & 0.409 & & 0.044 \\
\hline & & Maximum & 7.20 & 1.150 & 0.350 & & 7.400 & 4.500 & $<0.250$ & 0.1 \\
\hline & & Minimum & $<0.07$ & $<0.100$ & $<0.100$ & & $<0.070$ & $<0.060$ & & 0.017 \\
\hline & & Stand. Dev. & 1.333 & 0.396 & 0.110 & & 1.313 & 0.749 & & 0.038 \\
\hline & & Coef. Var. & 0.723 & 0.821 & 0.516 & & 2.864 & 1.831 & & 0.861 \\
\hline & & No. Analyses & $\overline{236}$ & $\overline{5}$ & $\overline{5}$ & $\overline{11}$ & 140 & 217 & 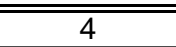 & $\overline{5}$ \\
\hline
\end{tabular}

George Delaney swallow hole, October 1993-September 1994

\begin{tabular}{|c|c|c|c|c|c|c|c|c|c|c|}
\hline $\begin{array}{l}\text { Sample } \\
\text { Number }\end{array}$ & Date & Time (CST) & $\begin{array}{c}\text { Total ELISA } \\
\text { Triazines } \\
(\mu \mathrm{g} / \mathrm{L})\end{array}$ & $\begin{array}{c}\text { Total GC } \\
\text { Atrazine } \\
(\mu \mathrm{g} / \mathrm{L})\end{array}$ & $\begin{array}{c}\text { Total GC } \\
\text { Simazine } \\
(\mu \mathrm{g} / \mathrm{L})\end{array}$ & $\begin{array}{c}\text { Total GC } \\
\text { Cyanazine } \\
(\mu \mathrm{g} / \mathrm{L})\end{array}$ & $\begin{array}{c}\text { Total ELISA } \\
\text { Carbofuran } \\
(\mu \mathrm{g} / \mathrm{L})\end{array}$ & $\begin{array}{c}\text { Total ELISA } \\
\text { Metolachlor } \\
(\mu \mathrm{g} / \mathrm{L})\end{array}$ & $\begin{array}{c}\text { Total GC } \\
\text { Metolachlor } \\
(\mu \mathrm{g} / \mathrm{L})\end{array}$ & $\begin{array}{c}\text { Total GC } \\
\text { Alachlor } \\
(\mu g / L)\end{array}$ \\
\hline GDSW0012 & Dec/07/1993 & $11: 40$ & 1.10 & & & & $<0.070$ & $<0.060$ & & \\
\hline GDSW0013 & Mar/28/1994 & $10: 40$ & 0.48 & & & & $<0.080$ & $<0.080$ & & \\
\hline GDSW0014 & Apr/07/1994 & $15: 00$ & 2.10 & & & & $<0.080$ & 0.140 & & \\
\hline GDSW0015 & Apr/20/1994 & $12: 10$ & 0.90 & & & & $<0.080$ & $<0.080$ & & \\
\hline GDSW0016 & Apr/26/1994 & $15: 30$ & 1.20 & & & & $<0.080$ & $<0.080$ & & \\
\hline GDSW0017 & May/12/1994 & $9: 50$ & 1.30 & & & & $<0.080$ & $<0.080$ & & \\
\hline GDSW0018 & May/17/1994 & $13: 28$ & 1.30 & & & & $<0.080$ & $<0.080$ & & \\
\hline GDSW0019 & Jun/01/1994 & $7: 36$ & 1.10 & & & & $<0.080$ & $<0.080$ & & \\
\hline GDSW0020 & Jun/15/1994 & $0: 20$ & 1.20 & & & & & $<0.080$ & & \\
\hline GDSW0021 & Jul/06/1994 & $9: 45$ & 1.10 & & & & & $<0.080$ & & \\
\hline & & Average* $^{*}$ & 1.178 & & & & & & & \\
\hline & & Maximum & 2.10 & & & & $<0.080$ & 0.140 & & \\
\hline & & Minimum & 0.48 & & & & & $<0.060$ & & \\
\hline & & No. Analyses & $\overline{10}$ & & & & 8 & 10 & & \\
\hline
\end{tabular}

*These statistics are presented as a descriptive summary of the table. The effects of aliasing and variable sampling intervals may significantly affect the validity of averages presented as representative of ground-water quality in the basin. No data means an analysis was not performed. 
Leslie Page karst window, October 1993-September 1994

\begin{tabular}{|c|c|c|c|c|c|c|c|c|c|c|}
\hline $\begin{array}{l}\text { Sample } \\
\text { Number }\end{array}$ & Date & Time (CST) & $\begin{array}{c}\text { Total ELISA } \\
\text { Triazines } \\
(\mu g / L)\end{array}$ & $\begin{array}{c}\text { Total GC } \\
\text { Atrazine } \\
(\mu g / L)\end{array}$ & $\begin{array}{c}\text { Total GC } \\
\text { Simazine } \\
(\mu g / L)\end{array}$ & $\begin{array}{c}\text { Total GC } \\
\text { Cyanazine } \\
(\mu \mathrm{g} / \mathrm{L})\end{array}$ & $\begin{array}{c}\text { Total ELISA } \\
\text { Carbofuran } \\
(\mu g / L)\end{array}$ & $\begin{array}{c}\text { Total ELISA } \\
\text { Metolachlor } \\
(\mu g / L)\end{array}$ & $\begin{array}{c}\text { Total GC } \\
\text { Metolachlor } \\
(\mu \mathrm{g} / \mathrm{L})\end{array}$ & $\begin{array}{c}\text { Total GC } \\
\text { Alachlor } \\
(\mu \mathrm{g} / \mathrm{L})\end{array}$ \\
\hline LPKW0019 & Oct/05/1993 & $13: 20$ & 0.12 & & & & $<0.070$ & $<0.060$ & & \\
\hline LPKW0020 & Nov/09/1993 & $9: 35$ & 0.15 & & & & & $<0.060$ & & \\
\hline LPKW0021 & $\mathrm{Dec} / 07 / 1993$ & $16: 53$ & 0.39 & & & & $<0.070$ & $<0.060$ & & \\
\hline \begin{tabular}{|l|} 
LPKW0022 \\
\end{tabular} & Jan/11/1994 & $14: 23$ & 0.34 & & & & $<0.080$ & $<0.080$ & & \\
\hline LPKW0023 & Feb/02/1994 & $9: 55$ & 0.07 & & & & $<0.080$ & $<0.080$ & & \\
\hline \begin{tabular}{|l|} 
LPKW 0024 \\
\end{tabular} & Feb/22/1994 & $13: 30$ & 0.57 & 0.220 & $<0.350$ & & $<0.080$ & $<0.080$ & $<0.023$ & $<0.017$ \\
\hline LPKW0026 & Mar/10/1994 & $19: 23$ & 3.00 & & & & $<0.080$ & 1.900 & & \\
\hline LPKW0027 & Mar/10/1994 & $19: 43$ & 3.10 & & & & $<0.080$ & 1.500 & & \\
\hline \begin{tabular}{|l|} 
LPKW0028 \\
\end{tabular} & Mar/10/1994 & $20: 03$ & 3.00 & & & & $<0.080$ & 2.100 & & \\
\hline LPKW0029 & Mar/10/1994 & $20: 23$ & 2.90 & & & & $<0.080$ & 2.100 & & \\
\hline LPKW0030 & Mar/10/1994 & $20: 43$ & 2.90 & & & & $<0.080$ & 2.000 & & \\
\hline LPKW0031 & Mar/10/1994 & $21: 03$ & 3.00 & & & & $<0.080$ & 2.000 & & \\
\hline \begin{tabular}{|l|} 
LPKW0032 \\
\end{tabular} & Mar/10/1994 & $21: 23$ & 2.80 & & & & $<0.080$ & 1.700 & & \\
\hline LPKW0033 & Mar/10/1994 & $21: 43$ & 2.80 & & & & $<0.080$ & 2.000 & & \\
\hline LPKW0034 & Mar/10/1994 & $22: 03$ & 2.60 & & & & $<0.080$ & 1.900 & & \\
\hline LPKW0035 & Mar/10/1994 & $22: 23$ & 2.60 & & & & $<0.080$ & 1.800 & & \\
\hline LPKW0036 & Mar/10/1994 & $23: 23$ & 2.30 & & & & $<0.080$ & 1.400 & & \\
\hline \begin{tabular}{|l|l} 
LPKW0037 \\
\end{tabular} & Mar/11/1994 & $0: 23$ & 2.40 & & & & $<0.080$ & 1.400 & & \\
\hline LPKW0038 & Mar/11/1994 & $1: 23$ & 3.50 & & & & $<0.080$ & 2.800 & & \\
\hline \begin{tabular}{|l|} 
LPKW0039 \\
\end{tabular} & Mar/11/1994 & $2: 23$ & 3.30 & & & & $<0.080$ & 2.500 & & \\
\hline LPKW0040 & Mar/11/1994 & $3: 23$ & 3.40 & & & & $<0.080$ & 2.300 & & \\
\hline LPKW0041 & Mar/11/1994 & $4: 23$ & 3.30 & & & & $<0.080$ & 2.500 & & \\
\hline LPKW0042 & Mar/11/1994 & $5: 23$ & 3.20 & & & & $<0.080$ & 2.600 & & \\
\hline LPKW0043 & Mar/11/1994 & $6: 23$ & 3.50 & & & & $<0.080$ & 2.500 & & \\
\hline LPKW0044 & Mar/11/1994 & $7: 23$ & 3.60 & & & & $<0.080$ & 2.600 & & \\
\hline LPKW0045 & Mar/11/1994 & $8: 23$ & 3.20 & & & & $<0.080$ & 2.500 & & \\
\hline \begin{tabular}{|l|l} 
LPKW0046 \\
\end{tabular} & Mar/11/1994 & $12: 23$ & 3.50 & & & & $<0.080$ & 2.500 & & \\
\hline LPKW0047 & Mar/11/1994 & $16: 23$ & 3.20 & & & & $<0.080$ & 2.300 & & \\
\hline \begin{tabular}{|l|} 
LPKW0048 \\
\end{tabular} & Mar/11/1994 & $20: 23$ & 3.40 & & & & $<0.080$ & 2.300 & & \\
\hline LPKW0049 & Mar/12/1994 & $0: 23$ & 3.10 & & & & $<0.080$ & 2.200 & & \\
\hline LPKW0050 & Mar/15/1994 & $17: 10$ & 1.60 & & & & $<0.080$ & 0.650 & & \\
\hline LPKW0051 & Mar/27/1994 & $15: 50$ & 3.30 & & & & $<0.080$ & 2.100 & & \\
\hline LPKW0052 & Mar/28/1994 & $9: 10$ & 2.70 & & & & $<0.080$ & 2.000 & & \\
\hline LPKW0053 & Mar/28/1994 & $9: 30$ & 2.70 & & & & $<0.080$ & 1.100 & & \\
\hline
\end{tabular}

${ }^{*}$ These statistics are presented as a descriptive summary of the table. The effects of aliasing and variable sampling intervals may significantly affect the validity of averages presented as representative of ground-water quality in the basin. No data means an analysis was not performed. 
Leslie Page karst window, October 1993-September 1994

\begin{tabular}{|c|c|c|c|c|c|c|c|c|c|c|}
\hline $\begin{array}{l}\text { Sample } \\
\text { Number }\end{array}$ & Date & Time (CST) & $\begin{array}{c}\text { Total ELISA } \\
\text { Triazines } \\
(\mu g / L)\end{array}$ & $\begin{array}{c}\text { Total GC } \\
\text { Atrazine } \\
(\mu \mathrm{g} / \mathrm{L})\end{array}$ & $\begin{array}{c}\text { Total GC } \\
\text { Simazine } \\
(\mu g / L)\end{array}$ & $\begin{array}{c}\text { Total GC } \\
\text { Cyanazine } \\
(\mu \mathrm{g} / \mathrm{L})\end{array}$ & $\begin{array}{c}\text { Total ELISA } \\
\text { Carbofuran } \\
(\mu g / L)\end{array}$ & $\begin{array}{c}\text { Total ELISA } \\
\text { Metolachlor } \\
(\mu g / L)\end{array}$ & $\begin{array}{c}\text { Total GC } \\
\text { Metolachlor } \\
(\mu \mathrm{g} / \mathrm{L})\end{array}$ & $\begin{array}{c}\text { Total GC } \\
\text { Alachlor } \\
(\mu \mathrm{g} / \mathrm{L})\end{array}$ \\
\hline LPKW0054 & Mar/28/1994 & $9: 50$ & 2.80 & & & & $<0.080$ & 1.200 & & \\
\hline LPKW0055 & Mar/28/1994 & $10: 10$ & 2.70 & & & & $<0.080$ & 1.200 & & \\
\hline LPKW0056 & Mar/28/1994 & $10: 30$ & 2.60 & & & & $<0.080$ & 1.100 & & \\
\hline LPKW0057 & Mar/28/1994 & $10: 50$ & 3.20 & & & & $<0.080$ & 1.100 & & \\
\hline LPKW0058 & Mar/28/1994 & $11: 10$ & 2.80 & & & & $<0.080$ & 1.100 & & \\
\hline LPKW0059 & Mar/28/1994 & $11: 30$ & 3.10 & & & & $<0.080$ & 1.100 & & \\
\hline LPKW0060 & Mar/28/1994 & $11: 50$ & 2.40 & & & & $<0.080$ & 1.100 & & \\
\hline LPKW0061 & Mar/28/1994 & $12: 10$ & 2.50 & & & & 0.290 & 1.300 & & \\
\hline LPKW0062 & Mar/28/1994 & $12: 30$ & 2.50 & & & & $<0.080$ & 1.100 & & \\
\hline LPKW0063 & Mar/28/1994 & $13: 30$ & 2.60 & & & & $<0.080$ & 1.100 & & \\
\hline LPKW0064 & Mar/28/1994 & $14: 30$ & 2.40 & & & & $<0.080$ & 1.200 & & \\
\hline \begin{tabular}{|l} 
LPKW0065 \\
\end{tabular} & Mar/28/1994 & $15: 30$ & 2.40 & & & & $<0.080$ & 1.000 & & \\
\hline LPKW0066 & Mar/28/1994 & $16: 30$ & 2.50 & & & & $<0.080$ & 1.100 & & \\
\hline LPKW0067 & Mar/28/1994 & $17: 30$ & 2.40 & & & & $<0.080$ & 1.000 & & \\
\hline LPKW0068 & Mar/28/1994 & $18: 30$ & 2.30 & & & & $<0.080$ & 0.920 & & \\
\hline LPKW0069 & Mar/28/1994 & 19:30 & 2.50 & & & & $<0.080$ & 0.970 & & \\
\hline LPKW0070 & Mar/28/1994 & $20: 30$ & 2.10 & & & & $<0.080$ & 0.840 & & \\
\hline LPKW0071 & Mar/28/1994 & $21: 30$ & 2.30 & & & & $<0.080$ & 0.990 & & \\
\hline LPKW0072 & Mar/28/1994 & $22: 30$ & 2.40 & & & & $<0.080$ & 0.880 & & \\
\hline LPKW0073 & Mar/29/1994 & $2: 30$ & 2.00 & & & & $<0.080$ & 0.780 & & \\
\hline LPKW0074 & Mar/29/1994 & $6: 30$ & 1.90 & & & & $<0.080$ & 0.720 & & \\
\hline \begin{tabular}{|l} 
LPKW0075 \\
\end{tabular} & Mar/29/1994 & $10: 30$ & 1.80 & & & & $<0.080$ & 1.100 & & \\
\hline LPKW0076 & Mar/29/1994 & $14: 30$ & 1.70 & & & & $<0.080$ & 0.920 & & \\
\hline LPKW0077 & Apr/07/1994 & $10: 55$ & 1.60 & & & & $<0.080$ & 0.390 & & \\
\hline LPKW0078 & Apr/12/1994 & $8: 06$ & 3.40 & & & & $<0.080$ & 1.300 & & \\
\hline LPKW0079 & Apr/20/1994 & $8: 15$ & 1.80 & & & & $<0.080$ & 0.410 & & \\
\hline LPKW0080 & Apr/27/1994 & $8: 31$ & 1.60 & & & & $<0.080$ & 0.380 & & \\
\hline LPKW0081 & May/02/1994 & $12: 23$ & 2.00 & & & & $<0.080$ & 0.660 & & \\
\hline LPKW0082 & May/03/1994 & $6: 00$ & 1.60 & & & & $<0.080$ & 0.340 & & \\
\hline LPKW0083 & May/04/1994 & $6: 00$ & 1.80 & & & & $<0.080$ & 0.360 & & \\
\hline LKPW0083 & May/04/1994 & $6: 00$ & 1.80 & & & & $<0.080$ & 0.360 & & \\
\hline LPKW0088 & May/09/1994 & $6: 00$ & 1.30 & & & & $<0.080$ & 0.410 & & \\
\hline \begin{tabular}{|l} 
LPKW0089 \\
\end{tabular} & May/11/1994 & $6: 00$ & 1.20 & & & & $<0.080$ & 0.390 & & \\
\hline LPKW0090 & May/12/1994 & $10: 40$ & 1.10 & & & & $<0.080$ & 0.430 & & \\
\hline
\end{tabular}

*These statistics are presented as a descriptive summary of the table. The effects of aliasing and variable sampling intervals may significantly affect the validity of averages presented as representative of ground-water quality in the basin. No data means an analysis was not performed. 
Leslie Page karst window, October 1993-September 1994

\begin{tabular}{|c|c|c|c|c|c|c|c|c|c|c|}
\hline $\begin{array}{l}\text { Sample } \\
\text { Number }\end{array}$ & Date & Time (CST) & $\begin{array}{c}\text { Total ELISA } \\
\text { Triazines } \\
(\mu g / L)\end{array}$ & $\begin{array}{c}\text { Total GC } \\
\text { Atrazine } \\
(\mu g / L)\end{array}$ & $\begin{array}{c}\text { Total GC } \\
\text { Simazine } \\
(\mu g / L)\end{array}$ & $\begin{array}{c}\text { Total GC } \\
\text { Cyanazine } \\
(\mu \mathrm{g} / \mathrm{L})\end{array}$ & $\begin{array}{c}\text { Total ELISA } \\
\text { Carbofuran } \\
(\mu g / L)\end{array}$ & $\begin{array}{c}\text { Total ELISA } \\
\text { Metolachlor } \\
(\mu g / L)\end{array}$ & $\begin{array}{c}\text { Total GC } \\
\text { Metolachlor } \\
(\mu g / L)\end{array}$ & $\begin{array}{c}\text { Total GC } \\
\text { Alachlor } \\
(\mu g / L)\end{array}$ \\
\hline$\overline{\text { LPKW0091 }}$ & May/13/1994 & $6: 00$ & 1.30 & & & & $<0.080$ & 0.390 & & \\
\hline LPKW0092 & May/14/1994 & $6: 00$ & 1.30 & & & & $<0.080$ & 0.490 & & \\
\hline LKPW0092 & May/14/1994 & $6: 00$ & 1.30 & & & & $<0.080$ & 0.490 & & \\
\hline LPKW0093 & May/15/1994 & $6: 00$ & 1.30 & & & & $<0.080$ & 0.160 & & \\
\hline$\overline{L P K W 0094}$ & May/16/1994 & $6: 00$ & 1.10 & & & & $<0.080$ & 0.410 & & \\
\hline LPKW0095 & May/17/1994 & $6: 00$ & 1.60 & & & & $<0.080$ & 0.450 & & \\
\hline LPKW0096 & May/18/1994 & $6: 00$ & 1.50 & & & & $<0.080$ & 0.310 & & \\
\hline LPKW0097 & May/20/1994 & $6: 00$ & 1.20 & & & & $<0.080$ & 0.190 & & \\
\hline LPKW0098 & May/22/1994 & $6: 00$ & 1.20 & & & & $<0.080$ & 0.170 & & \\
\hline LPKW0099 & May/24/1994 & $6: 00$ & 1.20 & & & & $<0.080$ & $<0.080$ & & \\
\hline LPKW0100 & May/25/1994 & $10: 45$ & 1.20 & & & & $<0.080$ & 0.250 & & \\
\hline LPKW0101 & May/27/1994 & $10: 45$ & 1.20 & & & & $<0.080$ & 0.210 & & \\
\hline LPKW0102 & May/29/1994 & $10: 45$ & 1.10 & & & & $<0.080$ & 0.200 & & \\
\hline LPKW0103 & May/31/1994 & $10: 45$ & 1.10 & & & & $<0.080$ & 0.190 & & \\
\hline$\overline{\text { LPKW0104 }}$ & Jun/01/1994 & $8: 30$ & 1.20 & & & & $<0.080$ & 0.210 & & \\
\hline LPKW0105 & Jun/15/1994 & $11: 35$ & 1.10 & & & & & 0.120 & & \\
\hline$\overline{\text { LPKW0106 }}$ & Jun/27/1994 & $23: 50$ & 0.91 & & & & & 0.320 & & \\
\hline LPKW0107 & Jun/28/1994 & $7: 50$ & 0.91 & & & & & 0.310 & & \\
\hline LPKW0108 & Jun/29/1994 & $7: 50$ & 0.90 & & & & & 0.280 & & \\
\hline LPKW0109 & Aug/02/1994 & $14: 20$ & 0.75 & & & & & 0.110 & & \\
\hline LPKW0110 & Sep/07/1994 & $12: 50$ & 0.52 & & & & & 0.140 & & \\
\hline \multicolumn{3}{|r|}{ Average* } & 2.091 & & & & & 1.048 & & \\
\hline \multicolumn{3}{|r|}{ Maximum } & 3.60 & & & & 0.290 & 2.800 & & \\
\hline \multicolumn{3}{|r|}{ Minimum } & 0.07 & & & & $<0.070$ & $<0.060$ & & \\
\hline \multicolumn{3}{|r|}{ Stand. Dev. } & 0.939 & & & & & 0.812 & & \\
\hline \multicolumn{3}{|r|}{ Coef. Var. } & 0.449 & & & & & 0.774 & & \\
\hline \multicolumn{3}{|r|}{ No. Analyses } & 89 & 1 & 1 & & 83 & 89 & 1 & 1 \\
\hline
\end{tabular}

*These statistics are presented as a descriptive summary of the table. The effects of aliasing and variable sampling intervals may significantly affect the validity of averages presented as representative of ground-water quality in the basin. No data means an analysis was not performed. 
Upper Pleasant Grove Creek, October 1993-September 1994

\begin{tabular}{|c|c|c|c|c|c|c|c|c|c|c|}
\hline $\begin{array}{l}\text { Sample } \\
\text { Number }\end{array}$ & Date & Time (CST) & $\begin{array}{c}\text { Total ELISA } \\
\text { Triazines } \\
(\mu g / L)\end{array}$ & $\begin{array}{c}\text { Total GC } \\
\text { Atrazine } \\
(\mu \mathrm{g} / \mathrm{L})\end{array}$ & $\begin{array}{c}\text { Total GC } \\
\text { Simazine } \\
(\mu \mathrm{g} / \mathrm{L})\end{array}$ & $\begin{array}{c}\text { Total GC } \\
\text { Cyanazine } \\
(\mu \mathrm{g} / \mathrm{L})\end{array}$ & $\begin{array}{c}\text { Total ELISA } \\
\text { Carbofuran } \\
(\mu g / L)\end{array}$ & $\begin{array}{c}\text { Total ELISA } \\
\text { Metolachlor } \\
(\mu g / L)\end{array}$ & $\begin{array}{c}\text { Total GC } \\
\text { Metolachlor } \\
(\mu \mathrm{g} / \mathrm{L})\end{array}$ & $\begin{array}{c}\text { Total GC } \\
\text { Alachlor } \\
(\mu \mathrm{g} / \mathrm{L})\end{array}$ \\
\hline UPGC0004 & Nov/18/1993 & $11: 31$ & 1.10 & & & & $<0.070$ & $<0.060$ & & \\
\hline UPGC0005 & $\mathrm{Dec} / 07 / 1993$ & $15: 10$ & 0.64 & & & & $<0.070$ & $<0.060$ & & \\
\hline UPGC0006 & Feb/22/1994 & $15: 16$ & 0.77 & & & & $<0.080$ & $<0.080$ & & \\
\hline UPGC0007 & Mar/28/1994 & $11: 05$ & 0.50 & & & & $<0.080$ & $<0.080$ & & \\
\hline UPGC0008 & Apr/07/1994 & $10: 25$ & 1.90 & & & & $<0.080$ & 0.270 & & \\
\hline UPGC0009 & Apr/20/1994 & $12: 25$ & 1.00 & & & & $<0.080$ & $<0.080$ & & \\
\hline UPGC0010 & Apr/27/1994 & $7: 10$ & 1.10 & & & & $<0.080$ & $<0.080$ & & \\
\hline UPGC0011 & May/12/1994 & $10: 10$ & 1.40 & & & & $<0.080$ & $<0.080$ & & \\
\hline UPGC0012 & May/17/1994 & $12: 13$ & 1.50 & & & & $<0.080$ & $<0.080$ & & \\
\hline UPGC0013 & Jun/01/1994 & $7: 07$ & 1.00 & & & & $<0.080$ & $<0.080$ & & \\
\hline UPGC0014 & Jun/15/1994 & $11: 00$ & 1.20 & & & & & $<0.080$ & & \\
\hline UPGC0015 & Jul/06/1994 & $7: 30$ & 1.20 & & & & & $<0.080$ & & \\
\hline \multicolumn{3}{|r|}{ Average $^{*}$} & 1.109 & & & & & & & \\
\hline \multicolumn{3}{|r|}{ Maximum } & 1.90 & & & & $<0.080$ & 0.270 & & \\
\hline \multicolumn{3}{|r|}{ Minimum } & 0.50 & & & & & $<0.060$ & & \\
\hline \multicolumn{3}{|r|}{ Stand. Dev. } & 0.383 & & & & & & & \\
\hline \multicolumn{3}{|r|}{ Coef. Var. } & 0.345 & & & & & & & \\
\hline \multicolumn{3}{|r|}{ No. Analyses } & 12 & & & & 10 & 12 & & \\
\hline
\end{tabular}

Miller School House water well, October 1993-September 1994

\begin{tabular}{|c|c|c|c|c|c|c|c|c|c|c|}
\hline $\begin{array}{l}\text { Sample } \\
\text { Number }\end{array}$ & Date & Time (CST) & $\begin{array}{c}\text { Total ELISA } \\
\text { Triazines } \\
(\mu g / L)\end{array}$ & $\begin{array}{c}\text { Total GC } \\
\text { Atrazine } \\
(\mu g / L)\end{array}$ & $\begin{array}{c}\text { Total GC } \\
\text { Simazine } \\
(\mu g / L)\end{array}$ & $\begin{array}{c}\begin{array}{c}\text { Total GC } \\
\text { Cyanazine } \\
(\mu \mathrm{g} / \mathrm{L})\end{array} \\
\end{array}$ & $\begin{array}{c}\text { Total ELISA } \\
\text { Carbofuran } \\
(\mu \mathrm{g} / \mathrm{L})\end{array}$ & $\begin{array}{c}\text { Total ELISA } \\
\text { Metolachlor } \\
(\mu \mathrm{g} / \mathrm{L})\end{array}$ & $\begin{array}{c}\text { Total GC } \\
\text { Metolachlor } \\
(\mu \mathrm{g} / \mathrm{L})\end{array}$ & $\begin{array}{c}\text { Total GC } \\
\text { Alachlor } \\
(\mu \mathrm{g} / \mathrm{L})\end{array}$ \\
\hline MSHW0001 & Apr/26/1994 & $14: 00$ & 0.070 & $<0.100$ & $<0.100$ & & $<0.080$ & $<0.080$ & $<0.250$ & $<0.100$ \\
\hline & & No. Analyses & 1 & 1 & 1 & & 1 & 1 & 1 & 1 \\
\hline
\end{tabular}

*These statistics are presented as a descriptive summary of the table. The effects of aliasing and variable sampling intervals may significantly affect the validity of averages presented as representative of ground-water quality in the basin. No data means an analysis was not performed. 


\section{APPENDIX J: Bacteria Analyses and Descriptive Statistics for the Pleasant Grove Spring Drainage Basin}


Pleasant Grove Spring, prior to June 1992

\begin{tabular}{|c|c|c|c|c|}
\hline $\begin{array}{l}\text { Sample } \\
\text { Number }\end{array}$ & Date & $\begin{array}{c}\text { Fecal } \\
\text { Coliform } \\
(\text { col/100 ml) }\end{array}$ & $\begin{array}{c}\text { Fecal } \\
\text { Streptococci } \\
\text { (col/100 ml) }\end{array}$ & $\begin{array}{c}\text { Fecal Coliform- } \\
\text { Fecal Strep } \\
\text { Ratio }\end{array}$ \\
\hline PGSP0001 & Aug/02/1990 & 518 & 9,000 & 0.06 \\
\hline PGSP0002 & Feb/28/1991 & 22 & 70 & 0.31 \\
\hline PGSP0003 & May/01/1991 & 136 & 70 & 1.94 \\
\hline PGSP0004 & May/22/1991 & 236 & 1,300 & 0.18 \\
\hline PGSP0005 & Jun/26/1991 & 418 & 16,000 & 0.03 \\
\hline PGSP0006 & Jul/25/1991 & 118 & 110 & 1.07 \\
\hline PGSP0008 & Sep/24/1991 & 3,400 & 540 & 6.30 \\
\hline PGSP0009 & Oct/22/1991 & 49 & 49 & 1.00 \\
\hline PGSP0011 & Jan/29/1992 & 18 & 130 & 0.14 \\
\hline PGSP0012 & Feb/26/1992 & 2,727 & 16,000 & 0.17 \\
\hline PGSP0013 & Mar/25/1992 & 90 & 230 & 0.39 \\
\hline PGSP0021 & Apr/29/1992 & 108 & 920 & 0.12 \\
\hline PGSP0026 & May/27/1992 & 180 & 350 & 0.51 \\
\hline & Average $^{\star}$ & 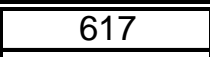 & 3,444 & 0.94 \\
\hline & Maximum & 3,400 & 16,000 & 6.30 \\
\hline & Minimum & 18 & 49 & 0.03 \\
\hline & Stand. Dev. & 1,104 & 6,068 & 1.70 \\
\hline & Coef. Var & 1.8 & 1.8 & 1.8 \\
\hline
\end{tabular}

Spring Valley karst window, prior to June 1992

\begin{tabular}{|c|c|c|c|c|}
\hline $\begin{array}{l}\text { Sample } \\
\text { Number }\end{array}$ & Date & $\begin{array}{c}\text { Fecal } \\
\text { Coliform } \\
\text { (col/100 ml) }\end{array}$ & $\begin{array}{c}\text { Fecal } \\
\text { Streptococci } \\
(\text { col/100 ml) }\end{array}$ & $\begin{array}{c}\text { Fecal Coliform- } \\
\text { Fecal Strep } \\
\text { Ratio }\end{array}$ \\
\hline SVKW0001 & Aug/02/1990 & 23 & 300 & 0.08 \\
\hline SVKW0002 & Feb/28/1991 & 33 & 50 & 0.66 \\
\hline SVKW0003 & May/22/1991 & 345 & 920 & 0.38 \\
\hline SVKW0004 & Jun/26/1991 & 264 & 5,400 & 0.05 \\
\hline SVKW0005 & Jul/25/1991 & 100 & 49 & 2.04 \\
\hline SVKW0007 & Sep/24/1991 & 700 & 2,400 & 0.29 \\
\hline SVKW0008 & Oct/22/1991 & 22 & 130 & 0.17 \\
\hline SVKW0009 & Jan/29/1992 & 18 & 220 & 0.08 \\
\hline SVKW0010 & Feb/26/1992 & 1,364 & 16,000 & 0.09 \\
\hline SVKW0011 & Mar/25/1992 & 90 & 330 & 0.27 \\
\hline SVKW0013 & Apr/29/1992 & 81 & 540 & 0.15 \\
\hline SVKW0014 & May/27/1992 & 297 & 170 & 1.75 \\
\hline & Average* & 278 & 2,209 & 0.50 \\
\hline & Maximum & 1,364 & 16,000 & 2.04 \\
\hline & Minimum & 18 & 49 & 0.05 \\
\hline & Stand. Dev. & 396 & 4,610 & 0.68 \\
\hline & Coef. Var. & 1.4 & 2.1 & 1.4 \\
\hline
\end{tabular}

*These statistics are presented as a descriptive summary of the table. The effects of aliasing and variable sampling intervals may significantly affect the validity of averages presented as representative of ground-water quality in the basin. 
The Canyon karst window, prior to June 1992

\begin{tabular}{|c|c|c|c|c|}
\hline $\begin{array}{l}\text { Sample } \\
\text { Number }\end{array}$ & Date & $\begin{array}{c}\text { Fecal } \\
\text { Coliform } \\
\text { (col/100 ml) }\end{array}$ & $\begin{array}{c}\text { Fecal } \\
\text { Streptococci } \\
\text { (col/100 ml) }\end{array}$ & $\begin{array}{c}\text { Fecal Coliform } \\
\text { Fecal Strep } \\
\text { Ratio }\end{array}$ \\
\hline TCKW0001 & Aug/02/1990 & 33 & 110 & 0.30 \\
\hline TCKW0002 & May/01/1991 & 11 & 49 & 0.22 \\
\hline TCKW0003 & May/22/1991 & 155 & 350 & 0.44 \\
\hline TCKW0004 & Jun/26/1991 & 91 & 3,500 & 0.03 \\
\hline TCKW0005 & Jul/25/1991 & 9 & 94 & 0.10 \\
\hline TCKW0007 & Sep/24/1991 & 300 & 130 & 2.31 \\
\hline TCKW0009 & Jan/29/1992 & 9 & 49 & 0.18 \\
\hline TCKW0010 & Feb/26/1992 & 18 & 350 & 0.05 \\
\hline TCKW0011 & Mar/25/1992 & 198 & 22 & 9.00 \\
\hline TCKW0013 & Apr/29/1992 & 27 & 23 & 1.17 \\
\hline TCKW0014 & May/27/1992 & 63 & 130 & 0.48 \\
\hline & Average* & 83 & $4 \overline{437}$ & 1.30 \\
\hline & Maximum & 300 & 3,500 & 9.00 \\
\hline & Minimum & 9 & 22 & 0.03 \\
\hline & Stand. Dev. & 96 & 1,022 & 2.64 \\
\hline & Coef. Var. & 1.2 & 2.3 & 2.0 \\
\hline
\end{tabular}

Shackelford Spring, prior to June 1992

\begin{tabular}{|c|c|c|c|c|}
\hline $\begin{array}{l}\text { Sample } \\
\text { Number }\end{array}$ & Date & $\begin{array}{c}\text { Fecal } \\
\text { Coliform } \\
\text { (col/100 ml) }\end{array}$ & $\begin{array}{c}\text { Fecal } \\
\text { Streptococci } \\
\text { (col/100 ml) }\end{array}$ & $\begin{array}{c}\text { Fecal Coliform } \\
\text { Fecal Strep } \\
\text { Ratio }\end{array}$ \\
\hline SKSP0001 & Aug/02/1990 & 8 & 20 & 0.40 \\
\hline SKSP0002 & Feb/28/1991 & 4 & 14 & 0.29 \\
\hline SKSP0003 & May/01/1991 & 58 & 23 & 2.52 \\
\hline SKSP0004 & May/22/1991 & 100 & 2,400 & 0.04 \\
\hline SKSP0005 & Jul/25/1991 & 4 & 49 & 0.08 \\
\hline SKSP0007 & Sep/24/1991 & 82 & 240 & 0.34 \\
\hline SKSP0008 & Oct/22/1991 & 49 & 49 & 1.00 \\
\hline SKSP0010 & $\operatorname{Jan} / 29 / 1992$ & 9 & 14 & 0.64 \\
\hline SKSP0011 & Feb/26/1992 & 54 & 130 & 0.42 \\
\hline SKSP0012 & Mar/25/1992 & 63 & 94 & 0.67 \\
\hline SKSP0013 & Apr/29/1992 & 10 & 5 & 2.00 \\
\hline SKSP0014 & May/27/1992 & 81 & 240 & 0.34 \\
\hline & Average* $^{\star}$ & $\overline{44}$ & 273 & 0.73 \\
\hline & Maximum & 100 & 2,400 & 2.52 \\
\hline & Minimum & 4 & 5 & 0.04 \\
\hline & Stand. Dev. & 35 & 675 & 0.77 \\
\hline & Coef. Var. & 0.8 & 2.5 & 1.1 \\
\hline
\end{tabular}

\footnotetext{
*These statistics are presented as a descriptive summary of the table. The effects of aliasing and variable sampling intervals
} may significantly affect the validity of averages presented as representative of ground-water quality in the basin. 
Thad Flowers blue hole, prior to June 1992

\begin{tabular}{|c|c|c|c|c|}
\hline $\begin{array}{l}\text { Sample } \\
\text { Number }\end{array}$ & Date & $\begin{array}{c}\text { Fecal } \\
\text { Coliform } \\
(\text { col/100 ml) }\end{array}$ & $\begin{array}{c}\text { Fecal } \\
\text { Streptococci } \\
(\text { col/100 ml) }\end{array}$ & $\begin{array}{c}\text { Fecal Coliform- } \\
\text { Fecal Strep } \\
\text { Ratio }\end{array}$ \\
\hline TFBH0001 & Feb/28/1991 & 3 & 7 & 0.43 \\
\hline TFBH0002 & May/01/1991 & 14 & 7 & 2.00 \\
\hline TFBH0003 & May/22/1991 & 7 & 540 & 0.01 \\
\hline TFBH0004 & Jun/26/1991 & 55 & 2,400 & 0.02 \\
\hline TFBH0005 & Jul/25/1991 & 573 & 3,500 & 0.16 \\
\hline TFBH0008 & Jan/29/1992 & 54 & 1,700 & 0.03 \\
\hline TFBH0009 & Feb/26/1992 & 90 & 1,600 & 0.06 \\
\hline TFBH0010 & Mar/25/1992 & 18 & 46 & 0.39 \\
\hline & Average $^{\star}$ & 102 & 1,225 & 0.39 \\
\hline & Maximum & 573 & 3,500 & 2.00 \\
\hline & Minimum & 3 & 7 & 0.01 \\
\hline & Stand. Dev. & 193 & 1,296 & 0.67 \\
\hline & Coef. Var. & 1.9 & 1.1 & 1.7 \\
\hline
\end{tabular}

George Delaney swallow hole, prior to June 1992

\begin{tabular}{|c|c|c|c|c|}
\hline $\begin{array}{l}\text { Sample } \\
\text { Number }\end{array}$ & Date & $\begin{array}{c}\text { Fecal } \\
\text { Coliform } \\
\text { (col/100 ml) }\end{array}$ & $\begin{array}{c}\text { Fecal } \\
\text { Streptococci } \\
\text { (col/100 ml) }\end{array}$ & $\begin{array}{c}\text { Fecal Coliform- } \\
\text { Fecal Strep } \\
\text { Ratio }\end{array}$ \\
\hline GDSW0001 & May/22/1991 & 391 & 3,500 & 0.11 \\
\hline GDSW0002 & Jun/26/1991 & 345 & 5,400 & 0.06 \\
\hline GDSW0003 & Jul/25/1991 & 1,800 & 3,500 & 0.51 \\
\hline GDSW0005 & Jan/29/1992 & 126 & 920 & 0.14 \\
\hline GDSW0006 & Feb/26/1992 & 14,000 & 24,000 & 0.58 \\
\hline GDSW0007 & Mar/25/1992 & 540 & 490 & 1.10 \\
\hline & Average* & 2,867 & 6,302 & $\overline{0.42}$ \\
\hline & Maximum & 14,000 & 24,000 & 1.10 \\
\hline & Minimum & 126 & 490 & 0.06 \\
\hline & Stand. Dev. & 5,486 & 8,860 & 0.40 \\
\hline & Coef. Var. & 1.9 & 1.4 & 1.0 \\
\hline
\end{tabular}

*These statistics are presented as a descriptive summary of the table. The effects of aliasing and variable sampling intervals may significantly affect the validity of averages presented as representative of ground-water quality in the basin. 
Pleasant Grove Spring, after October 1993

\begin{tabular}{|c|c|c|c|c|}
\hline $\begin{array}{l}\text { Sample } \\
\text { Number }\end{array}$ & Date & $\begin{array}{c}\text { Fecal } \\
\text { Coliform } \\
\text { (col/100 ml) }\end{array}$ & $\begin{array}{c}\text { Fecal } \\
\text { Streptococci } \\
\text { (col/100 ml) }\end{array}$ & $\begin{array}{c}\text { Fecal Coliform- } \\
\text { Fecal Strep } \\
\text { Ratio }\end{array}$ \\
\hline PGSP0344 & Mar/01/1994 & 85 & 171 & 0.497 \\
\hline PGSP0366 & Mar/29/1994 & 800 & 4,000 & 0.200 \\
\hline PGSP0392 & Apr/13/1994 & 1,273 & 1,441 & 0.883 \\
\hline PGSP0412 & Apr/27/1994 & 297 & 153 & 1.941 \\
\hline PGSP0449 & May/12/1994 & 180 & 90 & 2.000 \\
\hline PGSP0463 & Jun/01/1994 & 327 & 155 & 2.110 \\
\hline PGSP0529 & Jul/06/1994 & 10 & 216 & 0.046 \\
\hline & Average* & 425 & 889 & $\bar{~} 1.100$ \\
\hline & Maximum & 1,273 & 4,000 & 2.110 \\
\hline & Minimum & 10 & 90 & 0.050 \\
\hline & Stand. Dev. & 453 & 1,453 & 0.900 \\
\hline & Coef. Var. & 1.1 & 1.6 & 0.8 \\
\hline
\end{tabular}

The Canyon karst window, after October 1993

\begin{tabular}{|c|c|c|c|c|}
\hline $\begin{array}{l}\text { Sample } \\
\text { Number }\end{array}$ & Date & $\begin{array}{c}\text { Fecal } \\
\text { Coliform } \\
\text { (col/100 ml) }\end{array}$ & $\begin{array}{c}\text { Fecal } \\
\text { Streptococci } \\
\text { (col/100 ml) }\end{array}$ & $\begin{array}{c}\text { Fecal Coliform- } \\
\text { Fecal Strep } \\
\text { Ratio }\end{array}$ \\
\hline TCKW0015 & Jun/01/1994 & 11 & 36 & 0.306 \\
\hline TCKW0016 & Jul/06/1994 & 10 & 1,455 & 0.007 \\
\hline & Average* & $\overline{\overline{11}}$ & 746 & 0.16 \\
\hline
\end{tabular}

George Delaney swallow hole, after October 1993

\begin{tabular}{|c|c|c|c|c|}
\hline $\begin{array}{l}\text { Sample } \\
\text { Number }\end{array}$ & Date & $\begin{array}{c}\text { Fecal } \\
\text { Coliform } \\
\text { (col/100 ml) }\end{array}$ & $\begin{array}{c}\text { Fecal } \\
\text { Streptococci } \\
\text { (col/100 ml) }\end{array}$ & $\begin{array}{c}\text { Fecal Coliform- } \\
\text { Fecal Strep } \\
\text { Ratio }\end{array}$ \\
\hline GDSW0019 & Jun/01/1994 & 1,100 & 1,400 & 0.786 \\
\hline GDSW0021 & Jul/06/1994 & 1,273 & 5,364 & 0.237 \\
\hline & Average $^{\star}$ & $\overline{1,187}$ & 3,382 & $\overline{0.51}$ \\
\hline
\end{tabular}

*These statistics are presented as a descriptive summary of the table. The effects of aliasing and variable sampling intervals may significantly affect the validity of averages presented as representative of ground-water quality in the basin. 
Leslie Page karst window, after October 1993

\begin{tabular}{|c|c|c|c|c|}
\hline $\begin{array}{l}\text { Sample } \\
\text { Number }\end{array}$ & Date & $\begin{array}{c}\text { Fecal } \\
\text { Coliform } \\
\text { (col/100 ml) }\end{array}$ & $\begin{array}{c}\text { Fecal } \\
\text { Streptococci } \\
\text { (col/100 ml) }\end{array}$ & $\begin{array}{c}\text { Fecal Coliform- } \\
\text { Fecal Strep } \\
\text { Ratio }\end{array}$ \\
\hline LPKW0025 & Mar/01/1994 & 7 & 9 & 0.778 \\
\hline LPKW0080 & Apr/27/1994 & 45 & 3,636 & 0.012 \\
\hline LPKW0090 & May/12/1994 & 10 & 10 & 1.000 \\
\hline LPKW0104 & Jun/01/1994 & 1 & 218 & 0.005 \\
\hline LPKW0106 & Jul/06/1994 & 10 & 2,182 & 0.005 \\
\hline & Average* & $\overline{15}$ & $\overline{\overline{1,211}}$ & $\overline{0.36}$ \\
\hline & Maximum & 45 & 1,211 & 0.36 \\
\hline & Minimum & 1 & 9 & 0.00 \\
\hline & Stand. Dev. & 0.17 & 1,635 & 0.49 \\
\hline & Coef. Var. & 1.2 & 1.4 & 1.4 \\
\hline
\end{tabular}

*These statistics are presented as a descriptive summary of the table. The effects of aliasing and variable sampling intervals may significantly affect the validity of averages presented as representative of ground-water quality in the basin. 


\section{Water-Well Locations and Potentiometric Surface with Hypothesized Flow Routes}

Pleasant Grove Spring Karst Ground-Water Drainage Basin, Logan County, Kentucky

\section{EXPLANATION}
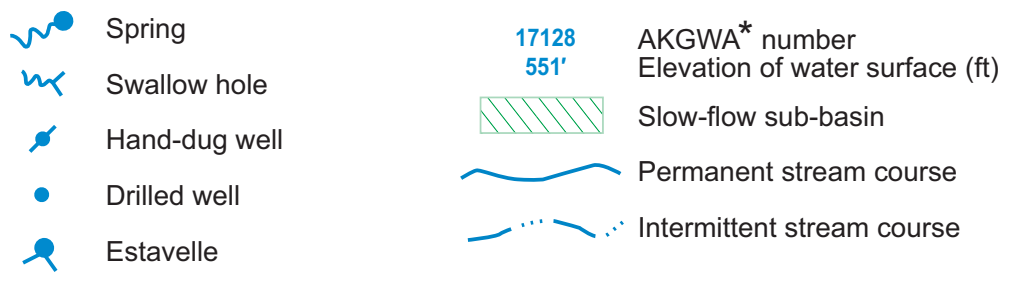

Kentucky Division of

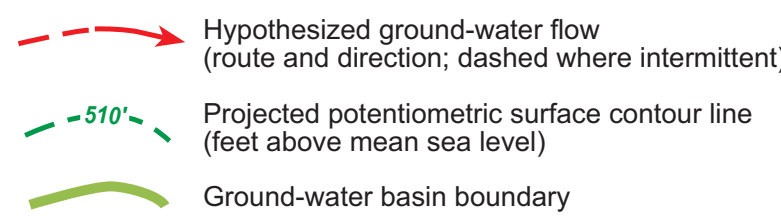

Water-level observations made between
June 2, 1993, and September 13, 1993

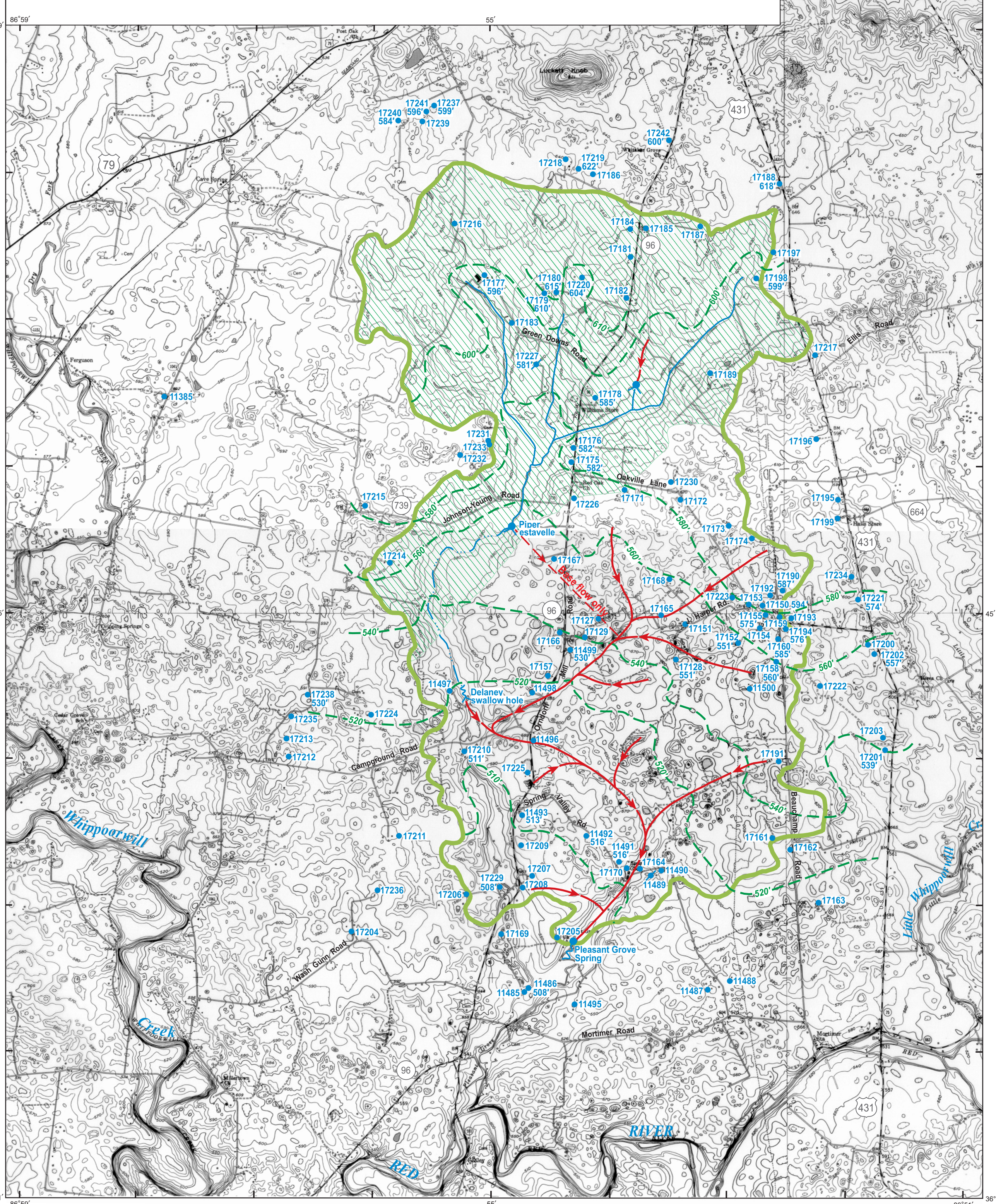




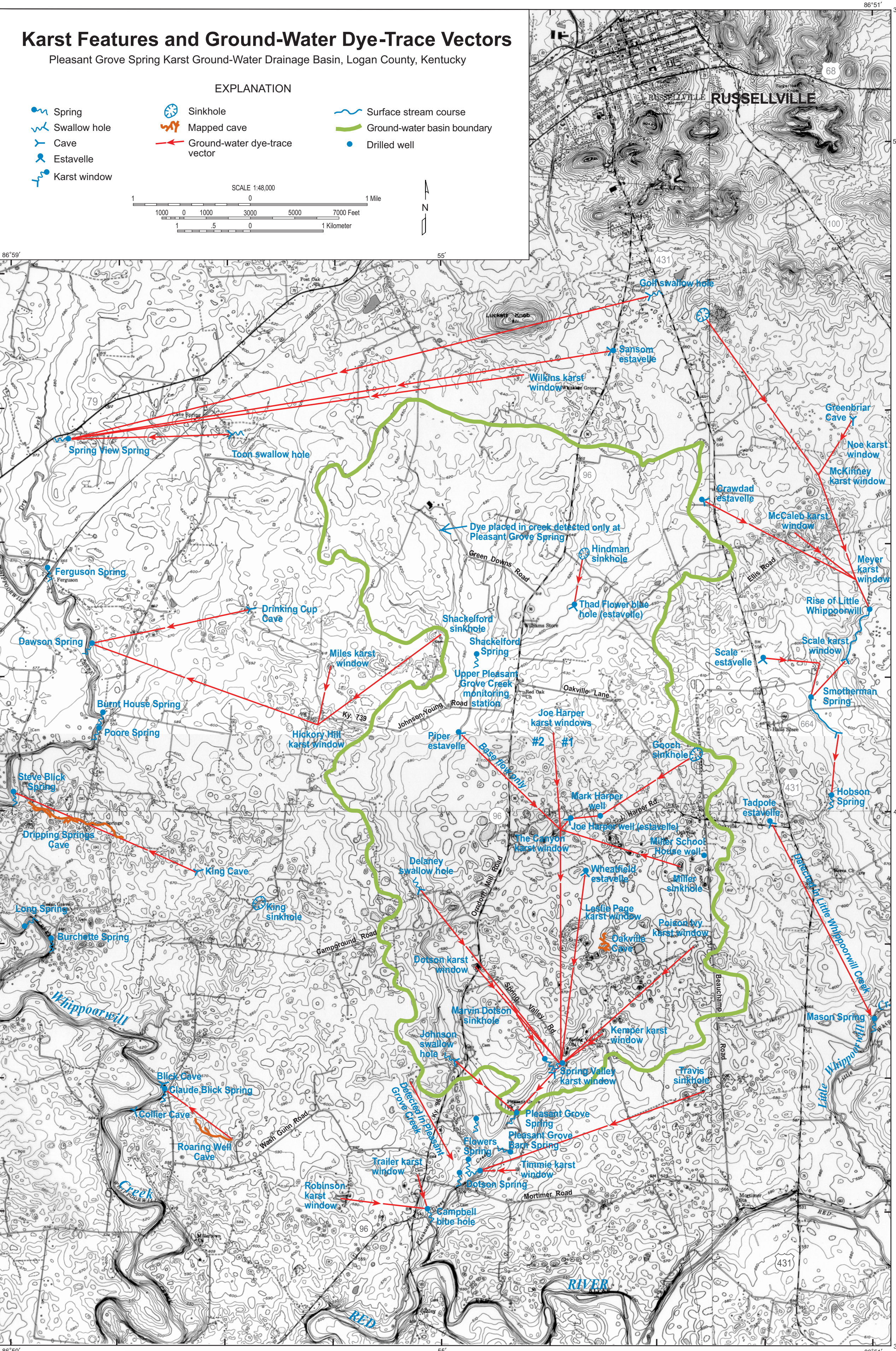




\section{Selected Water Resources Publications Available from the Kentucky Geological Survey}

KGS Information Circular 5 (ser. 11): Quality of surface water in Bell County, Kentucky, by R.B. Cook, Jr., and R.E. Mallette, 1981, 11 p. $\$ \mathbf{3} .00$

KGS Information Circular 37 (ser. 11): Water quality in the Kentucky River Basin, by D.I. Carey, 1992, 56 p. $\$ 4.00$

KGS Information Circular 44 (ser. 11): Quality of private ground-water supplies in Kentucky, by D.I. Carey and others, 1993,155 p. $\$ \mathbf{\$ 1 0 . 0 0}$

KGS Information Circular 46 (ser. 11): Impact of riparian grass filter strips on surface-water quality, by A.W. Fogle and others, 1994, 14 p. $\$ 3.00$

KGS Information Circular 52 (ser. 11): Ground water in the Kentucky River Basin, by D.I. Carey and others, 1994, 67 p. $\$ 9.95$

KGS Information Circular 60 (ser. 11): Ground-water quality in Kentucky: Nitrate-nitrogen, by P.G. Conrad and others, 1999, 4 p. $\$ \mathbf{1 . 5 0}$

KGS Map and Chart Series 10 (ser. 11): Mapped karst ground-water basins in the Lexington 30 x 60 minute quadrangle, by J.C. Currens and J.A. Ray, 1996, scale 1:100,000 \$5.00

KGS Map and Chart Series 16 (ser. 11): Mapped karst ground-water basins in the Harrodsburg 30 x 60 minute quadrangle, by J.C. Currens and J.A. Ray, 1998, scale 1:100,000 \$5.00

KGS Map and Chart Series 17 (ser. 11): Mapped karst ground-water basins in the Campbellsville 30 x 60 minute quadrangle, by J.A. Ray and J.C. Currens, 1998, scale 1:100,000 \$5.00

KGS Map and Chart Series 18 (ser. 11): Mapped karst ground-water basins in the Somerset 30 x 60 minute quadrangle, by J.C. Currens and J.A. Ray, 1998, scale 1:100,000 \$5.00

KGS Map and Chart Series 19 (ser. 11): Mapped karst ground-water basins in the Beaver Dam 30 x 60 minute quadrangle, by J.A. Ray and J.C. Currens, 1998, scale 1:100,000 \$5.00

KGS Report of Investigations 7 (ser. 11): Flooding of Sinking Creek karst area in Jessamine and Woodford Counties, Kentucky, by J.C. Currens and C.D.R. Graham, 1993, 33 p. $\$ \mathbf{\$ 4 0 0}$

KGS Report of Investigations 9 (ser. 11): Effects of longwall mining on hydrogeology, Leslie County, Kentucky; part 1: Premining conditions, by S.A. Minns and others, 1995, 37 p. $\quad \$ 7.50$

KGS Report of Investigations 10 (ser. 11): Hydrogeology, hydrogeochemistry, and spoil settlement at a large mine-spoil area in eastern Kentucky: Star Fire tract, by D.R. Wunsch and others, 1996, 49 p. $\quad \$ \mathbf{1 2 . 0 0}$

KGS Report of Investigations 11 (ser. 11): Hydrogeology and ground-water monitoring of coal-ash disposal sites in a karst terrane near Burnside, south-central Kentucky, by S.M. Hutcheson and others, 1997, 21 p. $\$ \mathbf{\$ 7 . 5 0}$

KGS Report of Investigations 12 (ser. 11): Fresh-water aquifer in the Knox Group (Cambrian-Ordovician) of central Kentucky, by J.A. Kipp, 1997, 15 p. $\quad \$ \mathbf{\$ 7 0}$

KGS Report of Investigations 13 (ser. 11): Impact of topographic data resolution on hydrologic and nonpoint-source pollution modeling in a karst terrane, by A.W. Fogle, 1998, 22 p. $\$ \mathbf{\$ 5 . 0 0}$

KGS Reprint 29 (ser. 11): Ordinance for the control of urban development in sinkhole areas in the Blue Grass karst region, Lexington, Kentucky, by J.S. Dinger and J.R. Rebmann, 1991, 14 p. \$2.50

KGS Reprint 30 (ser. 11): Stress-relief fracture control of ground-water movement in the Appalachian Plateaus, by J.A. Kipp and J.S. Dinger, 1991, 11 p. $\$ \mathbf{\$ 2 . 5 0}$

KGS Reprint 31 (ser. 11): High barium concentrations in ground water in eastern Kentucky, by D.R. Wunsch, 1991, 14 p. \$2.50

KGS Special Publication 1 (ser. 11): Bibliography of karst geology in Kentucky, by J.C. Currens and P. McGrain, 1979, 59 p. \$5.00

KGS Special Publication 12 (ser. 11): Caves and karst of Kentucky, ed. by P.H. Dougherty, 1985, 196 p. $\$ \mathbf{\$ 1 2 . 5 0}$

KGS Thesis Series 5 (ser. 11): Ground-water geochemistry and its relationship to the flow system at an unmined site in the Eastern Kentucky Coal Field, by D.R. Wunsch, 1993, 128 p. $\mathbf{\$ 1 0 . 0 0}$

KGS Thesis Series 6 (ser. 11): Conceptual model of local and regional ground-water flow in the Eastern Kentucky Coal Field, by S.A. Minns, 1993, 194 p. $\$ \mathbf{\$ 1 0 . 0 0}$

U.S. Geological Survey Open-File Report 80-685: A compilation of ground water quality data for Kentucky, by R.J. Faust, G.R. Banfield, and G.R. Willingers, 1980, 963 p. $\$ \mathbf{\$ 1 2 . 0 0}$

U.S. Geological Survey Hydrologic Atlases. Consult KGS “List of Publications” for specific locations and prices

U.S. Geological Survey Water-Supply Paper 2202: Chloroform contamination in part of the alluvial aquifer, southwest Louisville, Kentucky, by R.W. Davis and E.W. Matthews, 1994, 25 p. $\$ \mathbf{\$ 4 . 0 0}$

U.S. Geological Survey Water-Supply Paper 2254: Groundwater sensitivity regions of Kentucky, study and interpretation of the chemical characteristics of natural water, by J.D. Hem, 1994, 263 p., 3 plates $\$ \mathbf{\$ 1 5 . 0 0}$

Kentucky Department for Environmental Protection, Division of Water, Groundwater Branch, map: Groundwater sensitivity regions of Kentucky, 1994, scale 1:500,000 \$7.00

For information on obtaining copies of this publication and other Kentucky Geological Survey maps and publications, call: Publication Sales Office

(606) 257-3896

View the KGS World Wide Web site at www.uky.edu/kgs 